\section{OAK RIDGE \\ NATIONAL \\ LABORATORY}

MARTIN MARUETTA
Fossil Energy Program Semiannual Progress Report for April 1991 Through September 1991

\author{
R. R. Judkins
}


This report has been reproduced directly from the best available copy.

Available to DOE and DOE contractors from the Oftice of Scientific and Technical Information, P.O. Box 62, Oak Ridge, TN 37831; prices available from (615) 576-8401, FTS 626-8401.

Available to the public from the National Technical Information Service, U.S. Department of Commerce, 5285 Port Royal Rd., Springfield, VA 22161.

This report was prepared as an account of work sponsored by an agency of the United States Government. Neither the United States Government nor any agency thereof, nor any of their employees, makes any warranty, express or implied, or assumes any legal liability or responsibility for the accuracy, completeness, or usefulness of any information, apparatus, product, or process disclosed, or represents that its use would not infringe privately owned rights. Reference herein to any specific commercial product, process, or service by trade name, trademark, manufacturer, or otherwise, does not necessarily constitute or imply its endorsement, recommendation, or favoring by the United States Government or any agency thereof. The views and opinions of authors expressed herein do not necessarily state or reflect those of the United States Government or any agency thereot. 
ORNL- -6719

DE93 002624

Fossil Energy Program

\section{FOSSIL ENERGY PROGRAM SEMIANNUAL PROGRESS REPORT FOR APRIL 1991 THROUGH SEPTEMBER 1991}

R. R. Judkins

Program Manager

Date Published: October 1992

Prepared for the

DOE Office of Fossil Energy

(AA 000000 0)

Prepared by the

O.AK RIDGE NATIONAL LABORATORY

Oak Ridge, Tennessee 37831-6285

managed by

MARTIN MARIETTA ENERGY SYSTEMS, INC.

for the

U.S. DEPARTMENT OF ENERGY

under Contract DE-AC05-84OR21400 


\section{REPORTS PREVIOUSLY ISSUED IN THIS SERIES}

Previous reports in this series included quarterly and semiannual publications.

A complete listing of these reports through March 1989 is given in ORNL-6617.

ORNL-6617 Fossil Energy Program Semiannual Progress Report for April 1989 Through September 1989

ORNL-6634 Fossil Energy Program Semiannual Progress Report for October 1989 Through March 1990

ORNL-6650 Fossil Energy Program Semiannual Progress Report for April 1990 Through September 1990

ORNL-6718 Fossil Energy Program Semiannual Progress Report for October 1990 Through March 1991 
CONTENTS

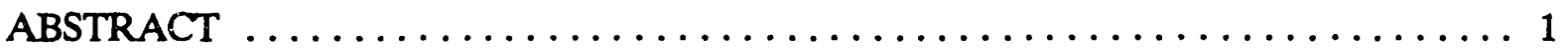

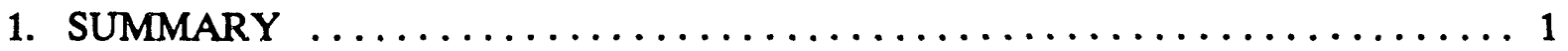

1.1 MATERIALS RESEARCH AND DEVELOPMENT $\ldots \ldots \ldots \ldots \ldots \ldots \ldots 1$

1.2 ENVIRONMENTAL ANALYSIS SUPPORT $\ldots \ldots \ldots \ldots \ldots \ldots \ldots \ldots$

1.3 COAL CONVERSION DEVELOPMENT $\ldots \ldots \ldots \ldots \ldots \ldots \ldots \ldots \ldots$

1.4 COAL COMBUSTION RESEARCH $\ldots \ldots \ldots \ldots \ldots \ldots \ldots \ldots \ldots \ldots$

1.5 FOSSIL FUELS SUPPLIES MODELING AND RESEARCH $\ldots \ldots \ldots \ldots 5$

1.6 EVALUATIONS AND ASSESSMENTS $\ldots \ldots \ldots \ldots \ldots \ldots \ldots \ldots \ldots$

1.7 COAL STRUCTURE AND CHEMISTRY $\ldots \ldots \ldots \ldots \ldots \ldots \ldots \ldots$

2. MATERIALS RESEARCH AND DEVELOPMENT $\ldots \ldots \ldots \ldots \ldots \ldots \ldots \ldots$

2.1 FABRICATION OF FIBER-REINFORCED COMPOSITES $\ldots \ldots \ldots \ldots \ldots 7$

2.1.1 Background $\ldots \ldots \ldots \ldots \ldots \ldots \ldots \ldots \ldots \ldots \ldots \ldots \ldots \ldots \ldots \ldots \ldots$

2.1.2 Approach $\ldots \ldots \ldots \ldots \ldots \ldots \ldots \ldots \ldots \ldots \ldots \ldots \ldots \ldots$

2.1.3 Discussion of Current Activities ............... 8

2.2 INTERFACES AND MECHANICAL PROPERTIES OF CONTINUOUS

FIBER-REINFORCED CERAMIC COMPOSITES ........... 11

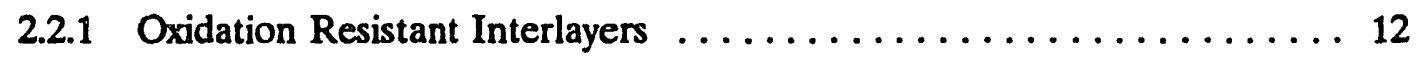

2.2.2 Sol-Gel Oxide Interlayers . . . . . . . . . . . . . . 15

2.2.3 Interlayer Property Effects $\ldots \ldots \ldots \ldots \ldots \ldots \ldots \ldots \ldots \ldots \ldots \ldots \ldots \ldots \ldots$

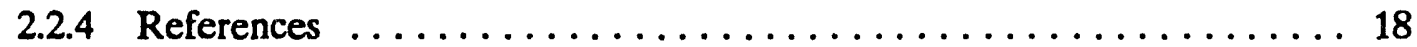

2.3 GAS SEPARATIONS USING INORGANIC MEMBRANES . . . . . . . 19

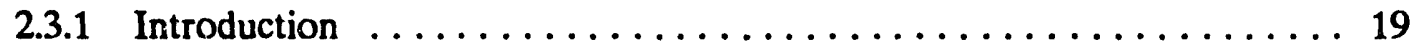

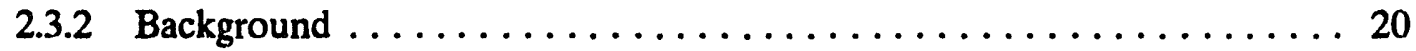

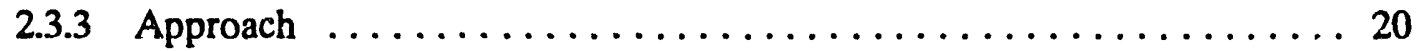

2.3.4 Discussion of Current Activities .................. 21

2.3.5 Permeability Measurements at Higher Temperatures .......... 21

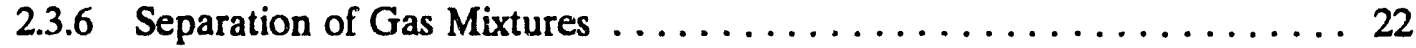

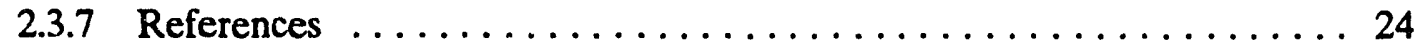


2.4 MICROWAVE SINTERING OF MATERIALS FOR FUEL CELLS . . . . 24

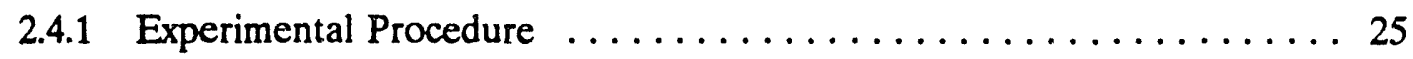

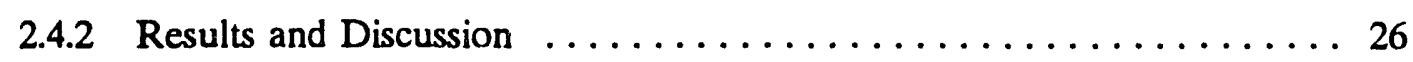

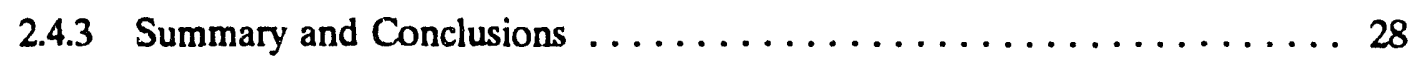

2.5 ENVIRONMENTAL EFFECTS ON IRON ALUMINIDES . . . . . . . 28

2.5.1 Air Oxidation Behavior of $\mathrm{Fe}_{3} \mathrm{Al}$ Alloys $\ldots \ldots \ldots \ldots \ldots \ldots \ldots$

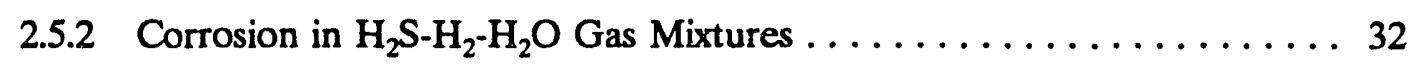

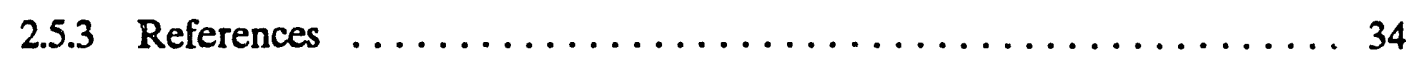

2.6 INVESTIGATION OF AUSTENITIC ALLOYS FOR ADVANCED HEAT

RECOVERY AND HOT-GAS CLEANUP SYSTEMS . . . . . . . . 35

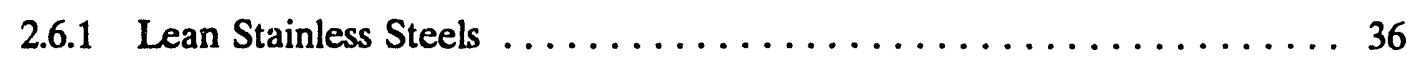

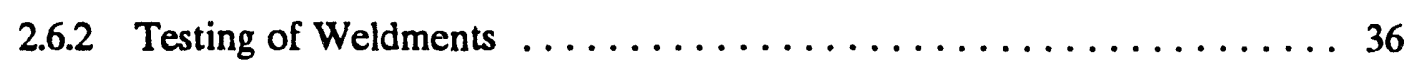

2.6.3 Evaluation of Modified Alloy $800 \mathrm{H} \ldots \ldots \ldots \ldots \ldots \ldots \ldots$

2.6.4 Alloys for Hot-Gas Cleanup Applications . . . . . . . . . . . . . . . 39

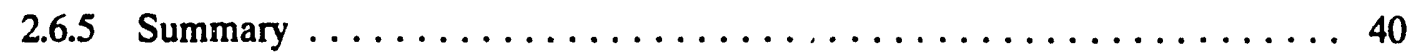

2.6 .6 References ........................ 40

2.7 DEVELOPMENT OF IRON ALUMINIDES $\ldots \ldots \ldots \ldots \ldots \ldots \ldots \ldots \ldots$

2.7.1 Alloy Development for Improved Creep Resistance . . . . . . . . . . . 42

2.7.2 Creep Mechanisms in $\mathrm{Fe}_{3} \mathrm{Al}$-Based Alloys .............. 44

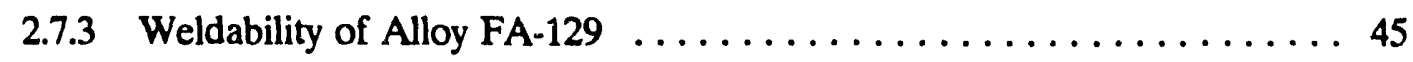

2.7.4 Weldability of Micro-Alloyed Iron Aluminides ............. 48

2.7.5 Preparation and Fabrication of Commercial-Size Ingots of $\mathrm{Fe}_{3} \mathrm{Al}$-Based Alloys $\ldots \ldots \ldots \ldots \ldots \ldots \ldots \ldots \ldots \ldots$

2.7.5.1 Melting $\ldots \ldots \ldots \ldots \ldots \ldots \ldots \ldots \ldots \ldots \ldots \ldots \ldots \ldots \ldots \ldots \ldots \ldots$

2.7.5.2 Cutting $\ldots \ldots \ldots \ldots \ldots \ldots \ldots \ldots \ldots \ldots \ldots \ldots \ldots \ldots \ldots \ldots \ldots \ldots$

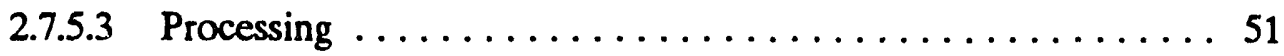

2.7.5.4 Mechanical Properties ................ 52

2.7 .6 Summary and Conclusions $\ldots \ldots \ldots \ldots \ldots \ldots \ldots \ldots \ldots \ldots$

2.7 .7 References $\ldots \ldots \ldots \ldots \ldots \ldots \ldots \ldots \ldots \ldots \ldots \ldots \ldots$

2.8 ELECTROSLAG CASTING TECHNOLOGY TRANSFER . . . . . . 60

2.8.1 Background .......................... 60

2.8.2 Results of Industrial Contacts $\ldots \ldots \ldots \ldots \ldots \ldots \ldots \ldots \ldots \ldots \ldots \ldots \ldots$ 
2.9 RESPONSES OF METALLIC AND OXIDE SURFACES TO

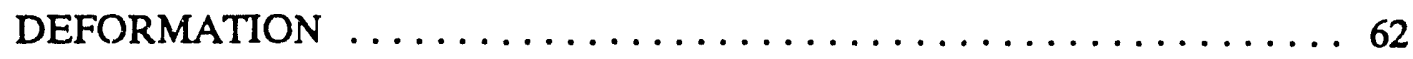

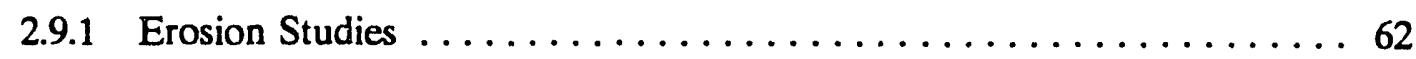

2.9.2 Mechanical Properties of Oxide Scales . . . . . . . . . . . . 68

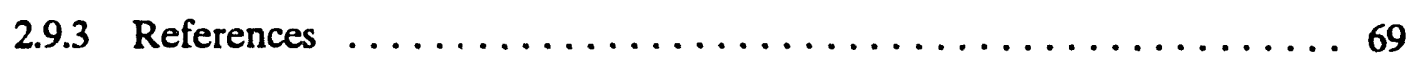

2.10 COAL CONVERSION AND UTILIZATION PLANT SUPPORT SERVICES 70

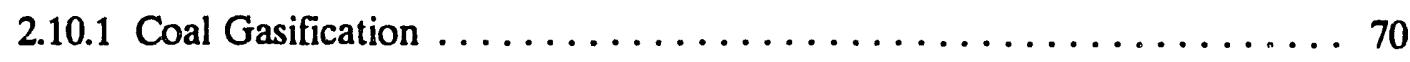

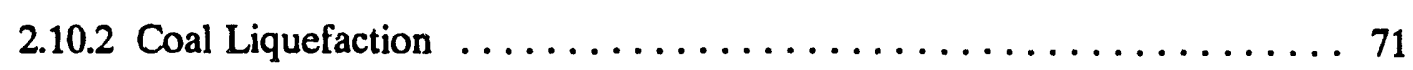

3. ENVIRONMENTAL ANALYSIS SUPPORT $\ldots \ldots \ldots \ldots \ldots \ldots \ldots \ldots \ldots \ldots \ldots \ldots \ldots \ldots \ldots \ldots$

3.1 ENVIRONMENTAL SUPPORT TO THE CLEAN COAL PROGRAM $\ldots 77$

3.2 ENVIRONMENTAL SUPPORT TO METC R\&D PROJECTS ........ 78

3.3 OIL RESEARCH PROGRAM ENVIRONMENTAL SUPPOR' $T \ldots \ldots \ldots 78$

3.4 ENVIRONMENTAL TRENDS ANALYSIS $\ldots \ldots \ldots \ldots \ldots \ldots \ldots \ldots . \ldots \ldots$

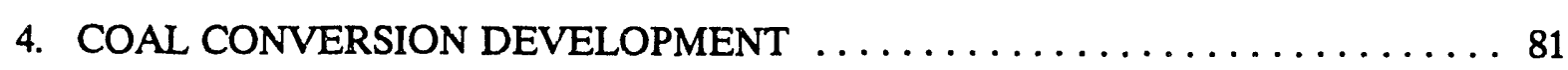

4.1 BIOPROCESSING RESEARCH $\ldots \ldots \ldots \ldots \ldots \ldots \ldots \ldots \ldots \ldots \ldots . \ldots \ldots$

4.1.1 Enzymatic Liquefaction of Coal $\ldots \ldots \ldots \ldots \ldots \ldots \ldots \ldots \ldots, 81$

4.1.1.1 Chemical Modification of Enzymes ............. 81

4.1.1.2 Degradation of Model Compounds $\ldots \ldots \ldots \ldots \ldots \ldots . \ldots 2$

4.1.1.3 Coal Liquefaction/Solubilization of Coal $\ldots \ldots \ldots \ldots \ldots 84$

4.1.1.4 Possible Processing System ................. 85

4.1.2 Microbial Heteroatom Removal from Coal-Derived Materials ...... 86

4.2 MILD GASIFICATION PRODUCT CHARACTERIZATION . . . . . . . 87

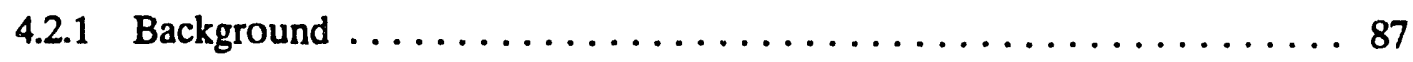

4.2.2 Project Description $\ldots \ldots \ldots \ldots \ldots \ldots \ldots \ldots \ldots \ldots \ldots \ldots \ldots$

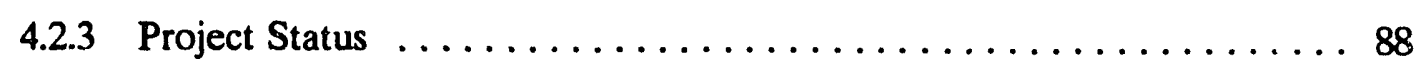

4.2.3.1 Char and Reference Fuel Samples .............. 88

4.2.3.2 Fixed-Bed Reactor Tests $\ldots \ldots \ldots \ldots \ldots \ldots \ldots \ldots \ldots 90$

4.2.3.3 Fixed-Bed Reactor Results .................. 90

4.2.3.4 Char Evaluation Conclusions ................. 91

4.2.3.5 Liquid Product Characterization ................. 91

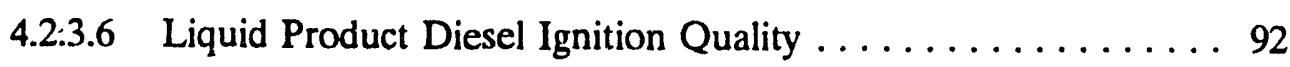

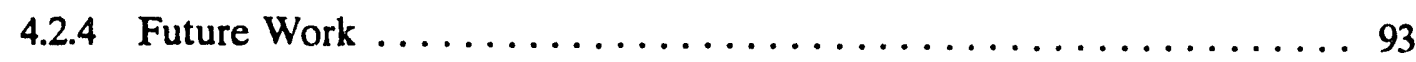

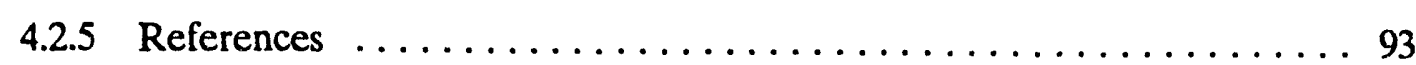


5. COAL COMBUSTION RESEARCH $\ldots \ldots \ldots \ldots \ldots \ldots \ldots \ldots \ldots \ldots \ldots$

5.1 ANALYSIS OF FBC DETERMINISTIC CHAOS $\ldots \ldots \ldots \ldots \ldots \ldots$

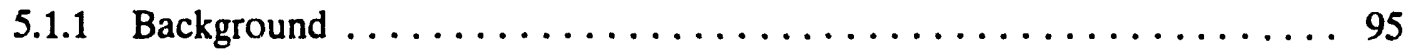

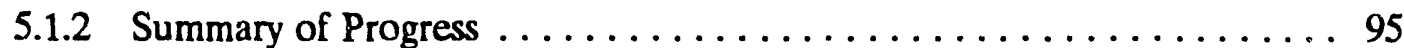

5.1.3 Analysis of Experimental Pressure and Voidage Signals .......... 95

5.1.4 A Bubble Growth Model for Fluidized Bed Chaos . . . . . . . . . . . . 97

5.1 .5 Future Activities $\ldots \ldots \ldots \ldots \ldots \ldots \ldots \ldots \ldots \ldots \ldots \ldots \ldots$

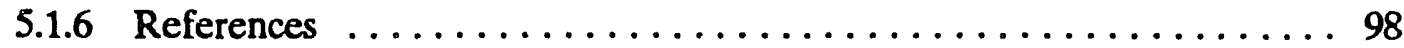

5.2 TECHNICAL SUPPORT TO PETC-USAID COLLABORATIVE

COAL PROJECTS ............................ 99

5.2 .1 Objectives $\ldots \ldots \ldots \ldots \ldots \ldots \ldots \ldots \ldots \ldots \ldots \ldots \ldots \ldots$

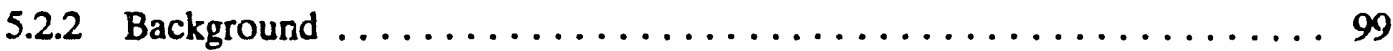

5.2.3 Project 1: Development of Pollution Control Strategies for Abatement of $\mathrm{NO}_{x}$ and $\mathrm{SO}_{2}$ Emissions from Coal-Fired Power Plants . 100

5.2.4 Project 2: Slagging Combustor Development of High-Ash Indian Coals 100

5.2.5 Project 3: Characterization of Indian Coals for Combustion

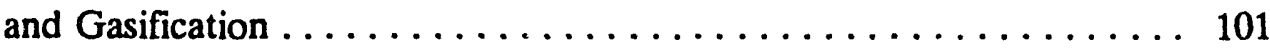

5.2.6 Project 4: Residual Life Assessment and Life Extension of Coal-Fired Power Plants . . . . . . . . . . . . . . . 101

5.2.7 Project 5: Environmental and Natural Resource Analysis of

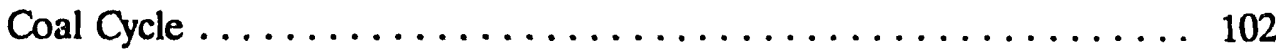

5.2 .8 Status Summary $\ldots \ldots \ldots \ldots \ldots \ldots \ldots \ldots \ldots \ldots \ldots \ldots$

6. FOSSIL FUEL SUPPLIES MODELING AND RESEARCH . . . . . . . . 107

6.1 STRATEGIC PETROLEUM RESERVE PLANNING AND MODELING 、 107

6.1.1 The Refined Petroleum Product Reserve . . . . . . . . . . . . . . . 107

6.1.2 Criteria for Deciding When to Use the SPR . . . . . . . . . 108

6.1.3 Increasing the SPR Drawdown Capability . . . . . . . . . . 108

6.1.4 References .................................. 109

7. EVALUATIONS AND ASSESSMENTS $\ldots \ldots \ldots \ldots \ldots \ldots \ldots \ldots \ldots \ldots \ldots$

7.1 FUEL CYCLE EXTERNAL COST ANALYSIS . . . . . . . . . . . 111

7.1.1 Background $\ldots \ldots \ldots \ldots \ldots \ldots \ldots \ldots \ldots \ldots \ldots \ldots \ldots \ldots \ldots \ldots \ldots$

7.1 .2 Methodology $\ldots \ldots \ldots \ldots \ldots \ldots \ldots \ldots \ldots \ldots \ldots \ldots \ldots \ldots$

7.1.3 Progress During the Period $\ldots \ldots \ldots \ldots \ldots \ldots \ldots \ldots \ldots \ldots \ldots$ 


\subsection{ANALYTICAL ASSISTANCE AND ANALYSIS FOR THE STRATEGIC}

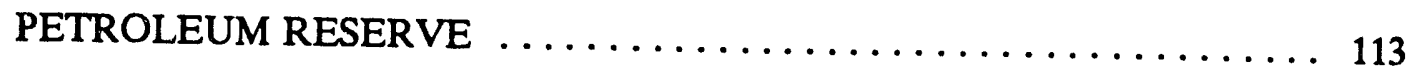

8. COAL STRUCTURE AND CHEMISTRY .................... 119

8.1 INVESTIGATION OF COAL SURFACES AND INTERFACES . . . . . . 119

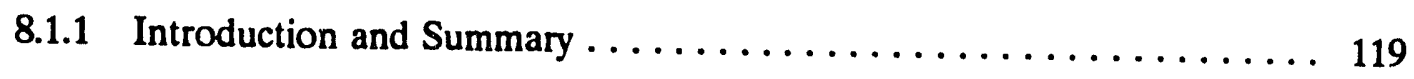

8.1 .2 Research Results ........................ 120

8.1.2.1 Coal Pyrite Structure and Morphology ............ 120

8.1.2.2 Mineral Pyrite Crystal Structure and

Specimen Preparation for TEM ................ 127

8.1.2.3 First Pyrite Oxidation Experiment $\ldots \ldots \ldots \ldots \ldots \ldots \ldots . \ldots \ldots \ldots$

8.1.2.4 Second Pyrite Oxidation Experiment ............. 134

8.1.3 Conclusions and Recommendations for Future Research ........ 137

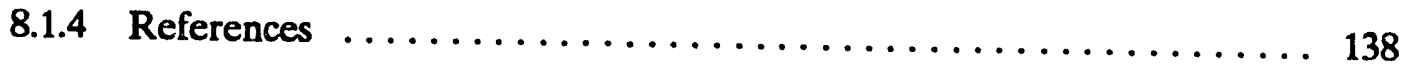




\title{
FOSSIL ENERGY PROGRAM SEMIANNUAL PROGRESS REPORT FOR APRIL 1991 THROUGH SEPTEMBER 1991
}

\author{
R. R. Judkins, Program Manager
}

\begin{abstract}
This report covers progress made during the period April 1, 1991, through September 30, 1991, for research and development projects that contribute to the advancement of various fossil energy technologies. Projects on the Fossil Energy Program are supported by the DOE Office of Fossil Energy, the DOE Morgantown Energy Technology Center, the DOE Pittsburgh Energy Technology Center, the DOE Fossil Energy Clean Coal Technology Program, the DOE Fossil Energy Office of Petroleum Reserves, and the U.S. Agency for International Development (USAID). The Fossil Energy Program organization chart is shown in the appendix.
\end{abstract}

\section{SUMMARY}

\subsection{MATERIALS RESEARCH AND DEVELOPMENT}

The materials research and development for fossil energy applications at Oak Ridge National Laboratory consists of ceramics development for high temperature applications, new metal alloys with unique mechanical properties, corrosion and erosion research to understand the material behavior in combustion and conversion environments. The transfer of technology funded under this program is enhanced with concerted efforts to interact with industry, perform joint programs and work with those interested in using the technology.

Emphasis this period was on: various methods of fabricating ceramic composite tubing by CVID infiltration of several preforms containing chopped fibers, ceramic membranes for hydrogen separation, the role that ionic and electronic conductivity play in the microwave sintering of lanthanum chromite for fuel cells and continuing alloy development of iron aluminides including creep testing, weldability, environmental effects and fracture behavior. Austenitic alloys were pursued for advanced heat recovery and hot gas cleanup, and fundamental studies on erosion/corrosion continued. Our materials technical support to the 
Wilsonville (Alabama) Advanced Coal Liquefaction Facility, the Great Plains Coal Gasification Plant, and selected Clean Coal Technology Program Projects has shown increased activity.

$\mathrm{SiC}$ has progressed to be a viable candidate for fossil systems applications, and a primary use would be in heat exchangers. Monolithic tubing is made commercially, but composite tubing is still under development. The forced chemical vapor infiltration deposition (FCVID) method of ORNL, incorporating a temperature gradient, shows the most promise for thicker wall tubing. Experiments have been performed using a variety of preforms and filler materials to build up the wall, reduce costs, and densify the tubing. Filament wound Nicalon ${ }^{\bullet}$ and 3-D braiding preforms were FCVID processed resulting in considerable porosity. A technique that appears to have much promise is a more loosely wound preform that was filled with chopped fibers prior to FCVID processing and resulted in less porosity. It also increases the potential for cost savings by reducing the amount of Nicalon ${ }^{\bullet}$ needed.

A process of producing ceramic membranes to separate hydrogen from gasified coal at high temperatures has now produced membranes with a mean pore radius of 5 angstroms and it offers potential for reducing the pore size further. To permit the membranes to be tested at $540^{\circ} \mathrm{C}\left(1000^{\circ} \mathrm{F}\right)$, a method for sealing the ceramic membranes to metal components had to be devised. To minimize stresses on the alumina membrane, a ring of niobium (which has a thermal expansion coefficient similar to alumina) was joined to the alumina tube and a stainless steel ferrule in one brazing cycle, using an active metal brazing filler metal.

With fuel cells, lanthanum chromite is often the design material that acts as the electrical interconnect between the stacks of electrolytic cells. A composition of lanthanum chromite was microwave sintered and annealed and the special microwave effect did not occur with this material as it did with alumina and zirconia. An investigation is underway to understand the role that ionic and electronic conductivity play in determining the microwave coupling of materials.

The evaluation of lean austenitic stainless steel is being completed. Long-time creep testing of the lean stainless steels have now exceeded $50,000 \mathrm{~h}$ at $700^{\circ} \mathrm{C}$ and continue to show excellent strength and ductility. Studies of the addition of nitrogen indicate that strengthening may occur without the need to cold or warm work the alloys to develop strongthening mechanisms. A modified alloy $800 \mathrm{H}$ that has been cold finished, solution treated at $1190^{\circ} \mathrm{C}$ and cold pilgered has twice the strength of alloy $800 \mathrm{H}$ at temperatures to $760^{\circ} \mathrm{C}$. Testing times are still short so long term stability is yet unknown. RA333 and Haynes alloy 556 have 
been examined for use in the Tidd hot-gas clean-up vessel and nickel-chromium-aluminides are being examined. Tensile, creep and relaxation testing was completed on an electroslag casting of alloy IC396M.

In supporting several fossil energy facilities, the staff of a coal gasification plant was assisted in identifying a means to eliminate corrosion in a distillation column. Specimens were provided to the Japanese for exposure in their coal liquefaction facility and specimens provided by the Japanese were prepared for exposure in reactor vessels at the Wilsonville Coal Liquefaction Research and Development Facility.

Research on $\mathrm{Fe}_{3}$ ini alloy: has shown that specific compositions coupled with thermomechanical processing techniques can produce room temperature ductilities of $10-20 \%$ and yield strengths of $500 \mathrm{MPa}$ up to $600^{\circ} \mathrm{C}$. The creep resistance can also be increased with small additions of $\mathrm{Mo}, \mathrm{Nb}$, and $\mathrm{Zr}$. The properties of commercially melted 2000 and $3000 \mathrm{~kg}$ heats of FA-129 were examined. Microalloying to produce improved creep resistance and yet retain weldability has been pursued. Analytical electron microscopy has been performed to identify precipitates and correlate precipitate compositions with properties.

Several iron aluminide compositions are being evaluated in atmospheres typical of coal gasifiers involving gases with relatively low oxygen and high sulfur activities. Specimens of $\mathrm{FeCrAl}$ were compared with $\mathrm{Fe}_{3} \mathrm{Al}$ alloys containing chromium after exposure to gas mixtures of $\mathrm{H}_{2} \mathrm{~S}-\mathrm{H}_{2}-\mathrm{H}_{2} \mathrm{O}$ at 700 to $800^{\circ} \mathrm{C}$. Again, the higher aluminum increases sulfidation resistance even in $\mathrm{FeCrAl}$ alloys when large amounts of chromium are also present. Aqueous corrosion studies have shown that the addition of 1 to 2 at.\% Mo significantly increases the resistance of $\mathrm{Fe}_{3} \mathrm{Al}$ alloys to attack in acid chloride solutions. When tested in the above sulfidizing atmospheres, the alloys containing 2 at.\% Mo and 0 and 4 at.\% $\mathrm{Cr}$ indicated significantly reduced corrosion rates when compared with chromium containing alloys with no molybdenum. Thus, Mo appears to suppress the adverse effect of $\mathrm{Cr}$ additions.

The mechanical properties of oxide scales affect the ability of high temperature materials to resist degradation by oxidation and corrosion. A mechanical properties microprobe was set to measure the hardness, Young's modulus, and plasticity of scales and bulk oxides by depth sensing submicron indentation testing. Emphasis was placed on the development of methodologies by focusing on an in-depth analysis of the various MPM data sets. 
The results of a seven year experimental program to examine erosion mechanisms in metallic alloys have been analyzed and the principal findings and conclusions are now summarized.

\section{ENVIRONMENTAL ANALYSIS SUPPORT}

Activities in environmental analysis support included assistance to the Morgantown and Pittsburgh Energy Technology Centers (METC and PETC) in reviewing and preparing documents required by the National Environmental Policy Act (NEPA) for several projects selected for the Clean Coal Program. A key activity was the preparation for PETC of a preliminaiy draft Environmental Impact Statement (EIS) for the Healy Clean Coal Project in Healy, Alaska. This work is notable because it is the first site-specific EIS prepared for the Clean Coal Program. Assistance also was provided to the DOE Office of Fossil Energy in evaluating the environmental aspects of projects proposed for cost-shared funding under the fourth round of the Clean Coal Program.

\subsection{COAL CONVERSION DEVELOPMENT}

Coal conversion research has continued on the biological solubilization of coal. A promising technique for enhancing the solubility of enzymes in organic media is being tested. Activities are also continuing on the study of mild gasification of coal. From previous studies it is known that mild gasification of coal produces liquids that are potentially useable as diesel fuel or diesel fuel diluents. However, the yield and quality of these liquids as well as the degree of upgrading required can vary substantially with the process severity (i.e., the degree of devolatilization). Char is similar in that the degree of devolatilization directly affects its combustion properties. The economic viability of any mild-gasification process is thus determined by tradeoffs among product yield, upgrading costs, and end-use requirements.

\subsection{COAL COMBUSTION RESEARCH}

Unique and innovative approaches are needed to optimize fossil energy conversion processes (such as fluidized bed combustion, coal gasification, hot-gas cleanup, oil-shale retorting, and catalytic cracking of petroleum) that employ fluidized beds for contacting streams of fluids and particulate solids. Of particular concern is the need to develop improved diagnostics for preventive maintenance, scale-up and engineering design procedures, and process control methods to maximize performance and minimize emissions. Recent research in physics and mathematics suggests that much of conventional dynamical theory is inadequate to 
accurately describe the behavior of nonlinear deterministic systems. Further, analysis of many commonplace phenomena such as fluid turbulence and mechanical vibration suggests that nonlinear processes are the rule rather than the exception. The body of literature that has been developed to encompass this area of research typically refers to such behavior as "deterministic chaos" or just "chaos" for short. Considering the highly turbulent nature of fluidized bed reactors, it is reasonable to expect that deterministic chaos is likely to be an important feature in their tehavior. Preliminary analyses of fluidized bed pressure drop and voidage data from ORNL and METC support this expectation.

In response to the request from the Pittsburgh Energy Technical Center (PETC), the Oak Ridge National Laboratory (ORNL) is providing technical assistance in the implementation of collaborative coal projects under the U.S. Agency for International Development (USAID)/Government of India (GOI) Phase II, Alte i: tive Energy Resources Development (AERD) Project. The PETC, USDOE under a Participation Agency Service Agreement (PASA) had the management responsibility for implementing the collaborative coal projects. In the FBC projects, ORNL and BHEL, Trichy, India, were designated as the lead institutions for the collaborative efforts.

\subsection{FOSSIL FUEIS SUPPLIES MODELING AND RESEARCH}

The current fossil fuel supply-related projects assist DOE in addressing policy issues related to strategic fuel reserves, reserve drawdown, and energy security.

\subsection{EVALUATIONS AND ASSESSMENTS}

It has long been known that the prices of using energy do not include all the costs and benefits of producing and delivering energy. Preparers of the 1990 National Energy Strategy recognized that the lack of high-quality information on external cost and benefits was distorting decision making at the federal and state levels. Consequently, a major initiative was launched by the Department of Energy (DOE) to provide best-practice information about the external physical impacts of energy use and how these impacts should be valued for planning and investment. In February 1991, DOE and the Commission of the European Communities (CEC) signed an agreement to develop a comparative analytical methodology and to develop the best range of estimates of costs from secondary sources for eight fuel cycles and four conservation options. Oak Ridge National Laboratory (ORNL) and Resources for the Future are the principal research institutions for the U.S. team. 
The simultaneous multielement analysis of crude oils at the parts-per-billion concentration levels has been achieved by combining chemical destruction of the crude oil with the detection sensitivity of the inductively coupled plasma mass spectrometer (ICP/MS) analyzer system. The four chemical preparation techniques evaluated were open vessel acid digestion, open vessel microwave digestion, high pressure sealed-vessel microwave digestion, and high pressure sealed tube digestion.

\subsection{COAL STRUCTURE AND CHEMISTRY}

During this period, research on the analytical characterization of coal surfaces and interfaces between coaì and various minerals was completed. Observations of pyrite microcrystals comprising framboid structures in bulk coal specimens that revealed a significant fraction of individual "crystallites" were, in fact, polycrystalline in nature. The results of the oxidation studies performed as a part of this project suggest that further work could be beneficial in terms of understanding surface and interfacial phenomena of mineral impurities in coal. 


\title{
2. MATERIALS RESEARCH AND DEVELOPMENT
}

\author{
N. C. Cole
}

This chapter describes research and development activities performed for the Fossil Energy Materials Program. Work on the Fossil Energy Materials Program includes the fabrication and characterization of fiber-reinforced ceramic composites, development of ceramic fiber-ceramic matrix hot-gas filters, development and testing of ceramic membranes for separation of gases, microwave sintering of materials for fuel cells, studies of environmental effects on iron aluminides, development and evaluation of advanced austenitic alloys, evaluation of materials for hot-gas filter support systems, development of iron aluminides, fundamental studies of erosion and corrosion, and materials testing and failure analysis support to coal conversion and utilization plants.

\section{FABRICATION OF FIBER-REINFORCED COMPOSITES - D. P. Stinton, R. A. Lowden, and T. M. Besmann}

The purpose of this task is to develop a ceramic composite having higher than normal strength and toughness yet retaining the normal ceramic attributes of refractoriness and high resistance to abrasion and corrosion. Ceramic fiber-ceramic matrix composites are being fabricated by infiltrating fibrous structures with vapors that deposit on and between the fibers to form the matrix of the composites.

\subsubsection{Background}

Fiber composites are in the limelight as a result of exceptionally high toughness values recently achieved for glass ceramics reinforced with silicon carbide fibers. Because use of ceramics is frequently restricted by inadequate toughness, any progress toward toughening ceramics will greatly expand their potential market. However, a generic problem that must be overcome is that normal ceramic fabrication processes tend to damage fibers mechanically and chemically when the fibers are consolidated within a ceramic matrix. The purpose of this task is to form the matrix by a comparatively low-stress, low-temperature chemical vapor deposition (CVD) infiltration process that will avoid the pitfalls of conventional ceramic processing.

As repor:ed previously, others have used CVD infiltration for fabricating ceramic composites. The vapor consolidation technique has been used to prepare fiber composites with matrices of carbon and/or such ceramics as $\mathrm{SiC}, \mathrm{Si}_{3} \mathrm{~N}_{4}, \mathrm{~B}_{4} \mathrm{C}, \mathrm{BN}$, and $\mathrm{TiB}_{2}$. 


\section{Approach}

Our goal is to demonstrate a rapid process for fabricating, via chemical vapor infiltration, a ceramic fiber-ceramic matrix composite consisting of materials of high interest to the fossil energy community. An initial assessment identified $\mathrm{SiC}$ fibers and matrices of $\mathrm{Si}_{3} \mathrm{~N}_{4}$ and $\mathrm{SiC}$ as being promising. An infiltrating process utilizing a thermal gradient combined with forced flow of the reactants is being pursued.

\subsection{Discussion of Current Activities}

Infiltration of tubular preforms of different fiber architestures continued this period. Nicalon preforms of a tubular geometry $(2.5$ to $3.8 \mathrm{~cm}$ ID by $0.6 \mathrm{~cm}$ wall thickness by $\approx 15 \mathrm{~cm}$ long) were fabricated with different fiber architectures. Filament winding of fiber tows was used to fabricate components that require high hoop or radial strengths but relatively modest axial strengths. A fiber architecture of this type would be ideal for combustors or headers. Three dimensional braiding was used to fabricate components for applications such as burner tubes or heat exchangers that require high axial strengths but only modest hoop strengths. Preforms were also fabricated by wrapping layers of cloth around a mandrel so that half the fibers were in the hoop direction and half in the axial direction.

Filament wound preforms formed on graphite mandrels were prepared by the K-25 Plant in Oak Ridge. The graphite mandrels contained hundreds of holes to permit ready access of reactant gases to the fibrous preform. Preforms were produced with the fibers $10^{\circ}$ off the hoop direction to insure adequate axial strength. Initially, space was left between fiber tows, however, large pores were aligned on top of each other. The winding technique was then modified to place adjacent tows in contact. This winding technique produced a density of about $47 \mathrm{vol} \%$ and prevented the formation of large pores in the preform.

Quadrax Corporation prepared 3D braided preforms on graphite mandrels for this study. The initial tubes were braided very loosely and contained only about 15 vol\% Nicalon $\bullet$ fibers. Near the ends of the preforms, the braided fibers were bound to the graphite mandrel with graphite yarn to prevent the braid from unraveling. Infiltration of such a low density preform proved to be impossible with the forced CVI process. Therefore, researchers at Quadrax Corporation modified their process in order to fabricate tubes containing up to $40 \mathrm{vol} \%$ Nicalon॰ fibers.

A process was developed to fabricate preforms for hot-gas filters that combines continuous and chopped fibers. The continuous fiber produces the strength, damage 
tolerance, and thermal shock resistance while the chopped fibers control the permeability and filtering efficiency of the filter surface. One further advantage of the process is that expensive Nicalon ${ }^{\bullet}$ fibers can be replaced by less expensive chopped alumina or Nextel fibers. Because of the reduced cost, hybrid preforms may also find application in heat exchangers or regenerators where strength requirements are quite modest. Hybrid preforms are fabricated by fiber molding chopped fibers into the open pores of braided or filament wound substrates. Hybrid preforms have proven to be ideal for hot gas filter applications. Fuli size candle filters ( $1.5 \mathrm{~m}$ long by $6 \mathrm{~cm}$ diam.) have been fabricated and are being tested at The 3M Company.

The forced chemical vapor infiltration process was recently modified so that tubular preforms could be infiltrated by creating a thermal gradient from the outside of the tube to the inside (Fig. 2.1). While the outside of the preform is heated, cold water is circulated through the stainless steel injector to cool the inside diameter of the fibrous preform. The gaseous reactants enter the furnace through tubing that runs within the water cooling passage. Reactants flow from the tubing in the cooling passage into a graphite gas distributor and are dispersed along the length of the preform through parallel slots in a graphite gas distributor. Reactants then proceed uniformly through holes in the graphite mandrel into the preform.

Densification of the tubular preforms occurs when hydrogen and methyltrichlorosilane $\left(\mathrm{CH}_{3} \mathrm{SiCl}_{3}\right.$ or MTS) flow through the mandrel. Decomposition of the MTS and deposition of $\mathrm{SiC}$ occurs as the gases approach the higher temperature regions near the outer diameter of the preform. Deposition of $\mathrm{SiC}$ within the hot region of the preform increases the density and thermal conductivity of the material. Therefore, the deposition zone moves from the outer diameter, hotter regions toward the inner diameter, cooler regions.

Filament wound preforms were effectively infiltrated from the outset using this system. The high fiber content of the preform produced a sufficient backpressure within the preform to disperse the reactants along the length of the tube allowing them to flow uniformly through the walls of the preform. The hottest regions of the preform densified first, however, which forced reactants into less dense areas of the preform. The microstructure of filament wound composites demonstrate that the limited amount of porosity is distributed uniformly through the thickness.

Braided preforms were much more difficult to infiltrate than filament wound preforms. Braided preforms with a fiber content of only 15 vol\% were investigated initially. The low fiber content and large gaps between fiber bundles created voids that extended through the 
ORNL-DWG 91-9920

\section{FORCED CVI PROCESS FOR INFILTRATING TUBULAR COMPOSITES}

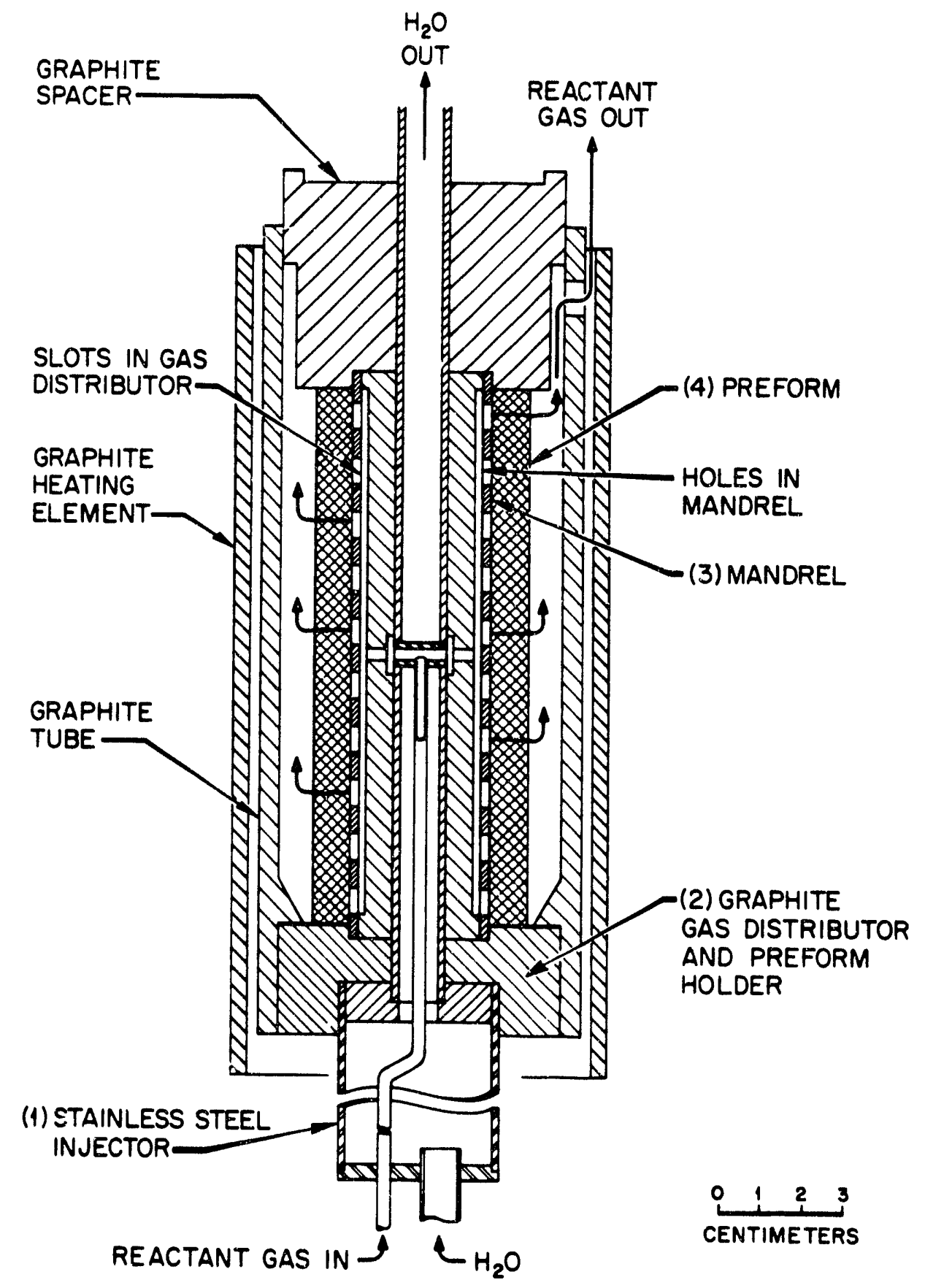

ornI

Fig. 2.1. Schematic of the forced CVI process used to infiltrate tubular composites. 
thickness of the preform. Because of these voids, no backpressure was created by the preform to disperse reactants along the length of the tube. Therefore, reactant gases entered the center of the preform and flowed directly through the walls so rapidly that very little $\mathrm{SiC}$ was deposited. Preforms that had been braided to a fiber loading of $33 \mathrm{vol} \%$ were also infiltrated. The porosity created by this braid was uniformly distributed, however the permeability was relatively high and reactants moved through the preform very rapidly. The high permeability of the preform failed to distribute the reactants uniformly along the length of the preform. More of the gases flowed through the center of the preform causing greater deposition near the center than near the ends of the preform. Braided preforms with still higher densities (i.e., reduced permeabilities) will be required to obtain proper infiltration.

Preforms fabricated for use as hot-gas filters or heat exchangers containing braided continuous fibers and fiber molded chopped fibers were also investigated. Since chopped fibers are much less permeable to gases than cloth, the hybrid preform created a significant backpressure that dispersed the reactants along the length of the tubular preform. Infiltration proceeded as desired. The reactants entered the preform, dispersed along the length of the preform, and flowed slowly through the walls of the preform. The uniform movement of reactants through the preform resulted in $\mathrm{SiC}$ being deposited in the hot outer region of the tube. After sufficient densification occurred, the infiltration proceeded to the center and inner diameter of the preform.

The characterization of tubular $\mathrm{SiC}$ matrix composites reinforced with Nicalon $\bullet$ fibers has been very limited. C-ring compression testing was performed on one filament wound $3.8 \mathrm{~cm}$ diameter $(6 \mathrm{~mm}$ wall thickness) tubular composite. The $16 \mathrm{~cm}$ long tubuiar composite was cut into $6 \mathrm{~mm}$ thick C-ring specimens. Room temperature compression testing of three of these rings ranged from $777 \mathrm{MPa}$ to $842 \mathrm{MPa}$. Testing at $1000^{\circ} \mathrm{C}$ resulted in slightly lower strengths that ranged from $574 \mathrm{MPa}$ to $603 \mathrm{MPa}$. Composites rcinforced with braided or filament wound preforms are currently being fabricated for tension/torsion testing at room and elevated temperature.

\subsection{INTERFACES AND MECHANICAL PROPERTIES OF CONTINUOUS FIBER- REINFORCED CERAMIC COMPOSITES - R. A. Lowden}

The purpose of this task is to examine fiber-matrix interfaces and optimize the mechanical behavior of continuous fiber-reinforced ceramic composites fabricated utilizing a forced-flow, thermal-gradient chemical vapor infiltration technique (FCVI). The strength and 
toughness of fiber-reinforced ceramic composites are controlled by the properties of the interface between the fiber and the matrix, thus emphasis is to be placed on developing methods to characterize the fiber-matrix interface and measure interfacial stresses in fiberreinforced ceramic composite systems. Coating or pretreatment processes can then be utilized to tailor the fiber-matrix interface within various composite systems and to optimize the strength and toughness of the composite.

\subsection{Oxidation Resistant Interlayers}

To date, emphasis in the development of continuous fiber-reinforced ceramic composites has been placed on processing and mechanical properties. Ceramic and glass-ceramic matrices are being reinforced with ceramic fibers and filaments, and moderate quantities of these materials are being fabricated using a variety of techniques. Although exceptional room and elevated temperature properties have been reported, only limited information has been presented regarding the stability of these composite systems in corrosive or simulated service environments. High temperature corrosion can have detrimental effects on the fibers and matrices and thus affect the properties of the composites. These issues must be addressed before final acceptance of these materials for critical components in elevated-temperature commercial applications.

It is well known that although the fibers and matrix play major roles in determining the final properties of a composite, the fiber-matrix interface has a significant influence on the fracture behavior and mechanical properties of reinforced ceramics. Typically, coatings are used to protect ceramic fibers from chemical attack during processing and to control interfacial forces. Carbon, whether intentionally deposited on the fibers prior to consolidation ${ }^{1,2}$ or formed serendipitously during processing, ${ }^{3}$ is the most commonly used interlayer in ceramic composites today. Carbon coatings have performed well in a variety of systems; including the Nicalon $\odot / S i C$ composites which have been the subject of this work. However, the poor oxidation resistance of carbonaceous materials has prompted intense scrutiny of their usefulness at elevated temperatures in oxidizing environments.

Carbon begins to oxidize at temperatures around $700^{\circ} \mathrm{K}$ and oxidation is rapid in air at temperatures above $1173^{\circ} \mathrm{K}$ It has been shown that the oxidation of Nicalon $\% / \mathrm{SiC}$ composites with a graphitic carbon interlayer begins by attack of the carbon interface coating at exposed fiber ends. ${ }^{4-6}$ Once the carbon is removed along the entire fiber length, the matrix and fiber oxidize to form a silica layer that eventually bonds the components together. The strong bond 
at the fiber-matrix interface does not permit fiber debonding and sliding, resulting in brittle behavior. Also, oxidation degrades the properties of the fiber, enhancing the embrittlement of the composite.

This poor oxidation resistance of carbon has lead to the examination of alternate coating materials or concepts for controlling the force at the fiber-matrix interface in ceramic-ceramic composites. Many factors must be considered in the selection of materials for interlayers in high-temperature composite systems. Chemical compatibility with the fibers and matrix, elevated temperature stability, and oxidation resistance are obvious requirements for an interface coating, however, the mechanical and physical properties of the coating also play an inportant role in determining interfacial bonding and shear stresses.

The theoretical aspects of thin films at the interface in whister- and fiber-reinforced ceramic composites and their effects on the stresses due thermal expansion mismatches have been examined. ${ }^{7}$ A reduction in thermomechanical stress is suggested only when a low modulus interfacial coating is present. For many composites, the matrix has a higher thermal expansion than the fiber thus upon cooling from processing temperatures, a clamping of the fibers occurs. An interlayer must alter the compressive stresses at the interface to permit debonding and produce low interfacial shear stress. A coating that is able to deform (i.e., low modulus), can act as a buffer layer and accommodate a portion of the residual clamping stress of the matrix, thus controlling interfacial shear and frictional forces.

Few materials possess all of the properties essential for the ideal interface layer, but as described, a graphitic carbon coating has proven to perform well in numerous ceramic composite systems including fiber-reinforced glasses and ceramics and $\mathrm{SiC}$ whisker-toughened alumina. It appears that the presence of the carbon interlayer alters the stresses at the interface. ${ }^{8.9}$ Graphitic carbon possesses an extremely low modulus along the c-axis. It is hypothesized that the carbon coating is able to deform and act as a buffer layer, accommodating a portion of residual clamping stresses of the matrix that occur due to thermal expansion differences between the fiber and matrix. The thickness of the carbon coating influences the clamping stress on the fiber and thus controls interfacial shear stress. Interfacial shear strength was shown to be inversely proportional to fiber coating thickness. Thicker coatings produce lower interfacial shear stresses because they are able to absorb more of the stress caused by the thermal expansion mismatch of the components. 
But again, carbon oxidizes at low temperatures, and thus other materials with mechanical and physical properties similar to carbon but possessing improved oxidation resistance are being examined. Much of the work on alternate interface coatings for silicon-based composite materials has paralleled the efforts to improve the oxidation resistance of carbonaceous materials, such as structural graphite and carbon-carbon composites. These efforts have focused on the development of glass forming materials, specifically glasses with melting temperatures and viscosities lower than that of pure silica. Boron is the most frequently studied addition to silica-forming materials for service temperatures around $1273^{\circ} \mathrm{K}$ $\left(1000^{\circ} \mathrm{C}\right) .^{10-15}$ The boron lowers the melting point of the glass that forms during oxidation. This allows the formation of a glass which will form and flow more readily at lower temperatures, offering improved protection for the composites in various relevant environments.

Hexagonal boron nitride posseses a structure and mechanical properties similar to those of graphite, however, due to the presence of boron, $\mathrm{BN}$ offers a distinct improvement in oxidation resistance. Boron nitride has been examined as an interface layer in this program in the past, but with the exception of a small sample of CVD coated fabric, ${ }^{2}$ all previous experiences with $\mathrm{BN}$-coated Nicalon ${ }^{\bullet}$ were disappointing. Attempts to deposit polycrystallineBN layers on the fibers using CVD techniques resulted in extensive damage to the fibers and amorphous deposits produced at low temperatures decomposed at room temperature.

Favorable results were obtained from the limited supply of CVD-coated fabric and there have been reports of improved long-term oxidation resistance for BN coated fibers in analogous composite systems. This prompted the re-evaluation of $\mathrm{BN}$ as an interface layer. Fibrous preforms and individual fabric layers have been coated with $\mathrm{BN}$ using techniques similar to those used in the deposition of the carbon interface coatings. Boron trichloride and ammonia were reacted in hydrogen at $1373^{\circ} \mathrm{K}$ and $0.033 \mathrm{~atm}$, conditions similar to those for the standard carbon interface coating. Deposition conditions were varied to alter the composition and the thickness of the interlayer. Experimental conditions were determined to deposit the appropriate interlayer composition and structure at rates similar to those for the graphitic carbon fiber coating. Although the strengths of the coated fibers were not measured, the fibers remained flexible and intact after deposition. The preforms have been densified

\footnotetext{
${ }^{2}$ Produced by Comurhex, CVD Department, Pierrolette, France.
} 
with a SiC matrix using the FCVI process. Specimens for mechanical property testing, corrosion studies, and elertron microscopy characterization are being prepared. The results of the characterization and testing will be compared to previous studies of the composites with a carbon interlayer.

Boron or borate glass additions have been used to improve the oxidation resistance of carbon and carbon-carbon composites. ${ }^{13-15}$ A similar approach is being examined to enhance the oxidation properties of the fiber-matrix interface coating. Boron is being added to the carbon interlayer during deposition process, again employing previously established techniques. Boron trichloride and hydrogen were introduced to the argon-propylene gas mixture that is typically employed to deposit the giaphitic carbon interlayer. The addition of the $\mathrm{BCl}_{3}$ and $\mathrm{H}_{2}$ produces boron carbide cispeisions in the carbon layer. Upon oxidation, $\mathrm{B}_{2} \mathrm{O}_{3}$ gals 3 will form and hinder further attack of the interface coating. The amount of boron in the layer is being varied. The experiments will determine the feasibility of this approach as well as the quantity of boron needed to provide adequate protection. Composites are being fabricated from the coated preforms, and both corrosion and flexure specimens are being prepared. The effects of the boron additions on the mechanical properties of the interface and composites, and the oxidation resistance of the material will be evaluated.

\section{Sol-Gel Oxide Interlayers}

Chemical vapor deposition is one of numerous methods that have been employed for the deposition of thin layers on the surface of fibers. Sol-gel techniques have also proven useful for producing coatings on fibers, especially for oxide coating compositions. Nicalon fabric samples were coated with oxide layers by Dr. Jay E. Lane at Westinghouse Science and Technology Center, Pittsburgh, Pennsylvania. Eight oxide compositions of two thicknesses were applied to Nicalon plain weave cloth using sol-gel techniques. The coatings included alumina, mullite, Ca-doped cordierite, alumina-magnesia-yttria, titania, zircon, zirconia, and Y-doped zirconia. The coated fabric samples were used to fabricate composites so that the effectiveness of oxide interlayers could be examined.

Nicalon fabric samples coated with the aforementioned oxide layers were incorporated into a $\mathrm{SiC}$ matrix employing the FCVI technique. Flexure specimens were prepared from the composites and tested in four-point bending. The mechanical property testing of the composites was paralleled by thermochemical evaluation of the chemical stability of the oxide as an interlayer in a non-oxide system as well as the survivability of the oxide layers during 
FCVI processing. The calculations required the addition of numerous compounds to the data base used by the SOLGASMIX-PV program. ${ }^{16}$ Extensive review of the literature and of the many oxide phase diagrams was necessary to complete the information. The calculations were used to aid in determining the most promising interface coating compositions and to assess the stability of the coatings in the Nicalon $\odot / \mathrm{SiC}$ system during fabrication and in service.

The thermomechanical aspects of the oxide interlayers were also considered. Following guidelines outlined by Hsueh, et al., ${ }^{7}$ calculations were performed to examine the effect of the oxide layers on the residual stresses in the system upon cooling from CVI processing temperatures. The axial and radial forces were examined, and the theoretical effectiveness of each material was addressed. The calculations were used to deternine which oxides may potentially reduce interfacial shear stresses and analyze the effect of interlayer thickness on residual stresses. The latter can be used to determine an approximate optimum thickness for each oxide composition.

$\mathrm{SiC}$ composites containing Nicalon fabric samples coated with alumina, titania, and zirconia performed well in the initial room temperature flexure tests. The test results support the theoretical calculations that predicted reductions in the residual stresses at the fiber-matrix interface in the Nicalon $\odot$ SiC system when using the aforementioned oxides. The decrease in residual stresses at the interface are necessary to permit fiber debonding and slip, and produce the desired gradual composite failure. Remaining pieces of coated fabric and the composites fabricated from such are being examined employing electron microscopy techniques. Coating compositions and integrity are being evaluated to facilitate the procurement of larger quantities of fabric coated the aforementioned materials. Composite specimens are to be fabricated to examine the long-term stability and corrosion resistance of Nicalon $\oplus$ Sic composites with oxide interlayers. Primary control of this work has been transfered to D. Matthew Walukus and will be completed under WBS Element UT-1.

\section{Interlayer Property Effects}

In previous periods, the influence of the fiber-matrix interface on the mechanical properties of Nicalon $\otimes / \mathrm{SiC}$ composites was investigated. Emphasis was placed on determining the relationships between interfacial forces and the flexure behavior of the composites, specifically matrix cracking stress, ultimate strength, and work of fracture, i.e., toughness. Interesting correlations between interlayer thickness, interfacial forces, and mechanical properties have been observed, ${ }^{1,28,9}$ however, little attention has been given to the effects of 
the interface on the interlaminar properties of the Nicalon $₫ / \mathrm{SiC}$ composites. Therefore, composite specimens with varying interfacial properties have been fabricated to examine the influence of interfacial shear stress on the interlaminar and impact properties of the materials.

As before, the thickness of the carbon layer has been varied to control the forces at the fiber-matrix interface. Shear and impact specimens have been prepared and are currently being tested. Composites with graphitic carbon coatings ranging in thickness from 0.03 to $1.25 \mu \mathrm{m}$ were fabricated. Flexure bars were prepared from each of the composites. The specimens were cut parallel to the $0^{\circ}$ orientation of the top layer of cloth using a diamond saw, and tensile and compression surfaces were ground parallel to the long axis of the specimen. The average dimensions of the specimens samples were $3 \times 4 \times 50 \mathrm{~mm}$ and all were measured and weighed to determine densities. Room temperature flexure strengths were measured in four-point bending using a support span of $40 \mathrm{~mm}$, a loading span of $20 \mathrm{~mm}$, and a crosshead speed of $0.508 \mathrm{~mm} / \mathrm{min}$. All specimens were loaded perpendicular to the layers of cloth. Load-displacement curves were recorded to examine the fracture process and were used to determine the loads for matrix fracture and ultimate strength. In general, a single matrix crack was observed in the tests and was noted as a sudden drop in the load-displacement curve and/or deviation from linearity. Flexure strengths are listed in Table 2.1.

Shear specimens and impact samples were also prepared from the composites. Both types of coupons were cut with the long axis parallel to the $0^{\circ}$ orientation of the fabic lay-up. The average dimensions of the specimens for the shear and impact specimens were $10 \times 20 \times 3 \mathrm{~mm}$ and $6 \times 6 \times 50 \mathrm{~mm}$, respectively. Again, all were weighed and measured to determine densities. Notches approximately $0.4 \mathrm{~mm}$ were cut across the $10 \mathrm{~mm}$ width at $5 \mathrm{~mm}$ from each end and on opposites sides of the shear specimens. Chevron notches were cut at the mid-point along the length of the impact specimens.

The shear specimens were tested at room temperature in compression with a cross head speed of $0.508 \mathrm{~cm} / \mathrm{min}$. The Chevron notch are being used to measure the work of fracture, or toughness, of the Nicalon $\odot / \mathrm{SiC}$ composites with varying interfacial shear strengths. Both slow testing in three point bending, and rapid testing in impact, are being conducted, and the measurements compared. The results will be used to further optimize the mechanical properties of the Nicalon $\otimes / \mathrm{SiC}$ composites. Table 2.1 also gives the shear measurements for the samples. 
Table 2.1. The influence of the carbon layer thickness on the properties of Nicalon $\odot / \mathrm{SiC}$ composites.

\begin{tabular}{ccccc}
\hline $\begin{array}{c}\text { Carbon } \\
\begin{array}{c}\text { Deposition } \\
\text { Time } \\
(\mathrm{h})\end{array}\end{array}$ & $\begin{array}{c}\text { Approximate } \\
\text { Interlayer } \\
\text { Thickness } \\
(\mu \mathrm{m})\end{array}$ & $\begin{array}{c}\text { Average } \\
\text { Flexure Bar } \\
\text { Density } \\
\left(\mathrm{g} / \mathrm{cm}^{3}\right)\end{array}$ & $\begin{array}{c}\text { Room Temp. } \\
\text { Flexure } \\
\text { Strength } \\
(\mathrm{MPa})\end{array}$ & $\begin{array}{c}\text { Room Temp. } \\
\text { Shear } \\
\text { Strength } \\
(\mathrm{MPa})\end{array}$ \\
\hline 0.00 & $n$ & $2.58 \pm 0.09$ & $64 \pm 11$ & $9 \pm 4$ \\
0.25 & 0.03 & $2.54 \pm 0.07$ & $273 \pm 30$ & $25 \pm 10$ \\
0.50 & 0.06 & $2.64 \pm 0.06$ & $402 \pm 24$ & $32 \pm 4$ \\
1.00 & 0.13 & $2.59 \pm 0.06$ & $421 \pm 27$ & $29 \pm 4$ \\
2.00 & 0.27 & $2.60 \pm 0.08$ & $399 \pm 28$ & $25 \pm 2$ \\
4.00 & 0.61 & $2.54 \pm 0.05$ & $304 \pm 30$ & $20 \pm 4$ \\
8.00 & 1.25 & $2.58 \pm 0.06$ & $271 \pm 32$ & $21 \pm 3$ \\
\hline
\end{tabular}

\section{References}

1. R. A. Lowden, Characterization and Control of the Fiber-Matrix Interface in Ceramic Matrix Composites, ORNLTM-11039, Oak Ridge National Laboratory, Oak Ridge, Tennessee, March 1989.

2. R. A Lowden and K L . More, "The Effect of Fiber Coatings on Interfacial Shear Strength and the Mechanical Behavior of Ceramic Composites," MRS Symposium Proceedings, Vol. 170, Tailoring Multiphase and Composite Ceramics (March 1989).

3. J. J. Brennan, "Interfacial Characterization of Glass and Glass-Ceramic Matrix/Nicalon SiC Fiber Composites," MRS Proceedings, Vol. 20, Tailoring Multiphase and Composite Ceramics, ed. R. E. Tressler et al., Plenum Publishing Corporation, 549-560 (1986).

4. R. A. Lowden and R. D. James, High Temperature Corrosion of Nicalon $\odot$ SiC Composites, ORNL/TM-11893, Oak Ridge National Laboratory, Oak Ridge, Tennessee, August 1991.

5. R. A. Lowden and R. D. James, "Effects of Oxidation and Combustion Environments on the Properties of Nicalon $\oplus$ SiC Composites," Proceedings of the Fifth Annual Conference on Fossil Energy Materials, ed. by R. Judkins, Oak Ridge, Tennessee, May 15-17, 1991.

6. R. D. James, R. A. Lowden, and K. L. More, The Effects of Oxidation and Corrosion on the Properties of Nicalon $\odot$ /SiC Composites," pp. 925-935 in Ceramic Transactions, Vol. 19, Advanced Composite Materials, ed. by Michael D. Sacks, The American Ceramic Society, Westerville, Ohio (1991). 
7. C.-H. Hsueh, P. F. Becher, and P. Angelini, "Effects of Interfacial Films on Thermal Stresses in Whisker-Reinforced Ceramics," J. Am. Ceram. Soc. 71(11), $929-933$ (1988).

8. R. A. Lowden, "Fiber Coatings and the Mechanical Properties of a Fiber-Reinforced Ceramic Composite," pp. 619-630 in Ceramic Transactions, Vol. 19, Advanced Composite Materials, ed. by Michael D. Sacks, The American Ceramic Society, Westerville, Ohio (1991).

9. R. A. Lowden, "Interface Effects and Fracture in Nicalon $\bullet / S i C$ Composites," pp. 97-114 in the Proceedings of the Fourth Annual Conference on Fossil Energy Materials, ed. by R. Judkins, Oak Ridge, Tennessee, May 15-17, 1990.

10. P. E. Gray, "Oxidation Inhibited Carbon-Carbon Composites,"

U. S. Patent Appl. 676,985, Nov. 30,1984.

11. P. E. Gray and J. E. Sheehan, "Oxidation Protected Carbon-Carbon Composite Development," NASA Conference Publication 2445, Metal Matrix, Carbon, and Ceramic Matrix Composites 1986, Edited by J. D. Buckley, Cocoa Beach, Florida, January 1986.

12. D. M. Shuford, "Enhancement Coatings and Process for Carbonaceous Substrates," U. S. Patent 4,471,023, September 1984.

13. P. Ehrburger, P. Baranne, and J. Lahaye, "Inhibition of the Oxidation of Carbon-Carbon Composite by Boron Oxide," Carbon 2A(4), 495-99 (1986).

14. D. W. McKee, C. L. Spiro, and E. J. Lamby, "The Effects of Boron Additives on the Oxidation Behavior of Carbons," Carbon 22(6), 507-511 (1984).

15. W. D. Kingery, "Surface Tension of Some Liquid Oxides and Their Temperature Coefficients," J. Am. Ceram. Soc. 42(1), 6-10 (1959).

16. T. M. Besmann, SOLGAS-PV, A Computer Program to Calculate Equilibrium Relationships in Complex Chemical Systems, ORNL/TM-5775, Oak Ridge National Laboratory, Oak Ridge, Tennessee, April 1977.

23 GAS SEPARATIONS USING INORGANIC MEMBRANES - B. Z. Egan, S. P. N. Singh, D. E. Fain, G. E. Roettger, and D. E. White

\subsection{Introduction}

The objective of this project is to develop, fabricate, and evaluate inorganic membranes for separating gases at high temperatures and pressures and/or in hostile process environments encountered in fossil energy conversion processes such as coal gasification. Major tasks presently being investigated include (1) fabrication and physical characterization of membranes at the Oak Ridge K-25 Site [K-25], and (2) evaluation of the separations capability of the 
fabricated membranes in terms of permeabilities and fluxes of gases using a testing apparatus at Oak Ridge National Laboratory (ORNL).

\subsection{Background}

Synthesis gas produced in coal gasification processes contains hydrogen, carbon monoxide, nitrogen, water, carbon dioxide, and hydrogen sulfide, along with small amounts of other gases. Inorganic membranes could potentially be used to separate these gases under gasifier exit gas conditions, and thereby significantly improve process efficiency and economics. Polymeric membranes have been used on a commercial scale to separate various gases. These membranes have limited thermal stability and are susceptible to abrasion and chemical attack. Consequently, they cannot be utilized in many separation processes where high temperatures and harsh environmental conditions are encountered.

Several porous inorganic materials that could be used as membranes are commercially available, but the minimum pore diameter is in the range of 30-40 angstroms. While some gas separations can be achieved with these materials, it is generally accepted that smaller pore diameters or other membrane modifications will be needed for efficient gas separations.

\section{Approach}

Several tasks have already been completed as part of this R\&D program. The literature on inorganic membrane R\&D to separate gases was compiled and summarized in a report. ${ }^{1}$ The performance targets for a membrane separation process applied to a coal gasification process were determined, based on the operating temperatures, pressures and gas flux requirements. Potential membrane materials were selected, based on thermal and chemical stability, availability, and cost of raw materials, and effects on gas transport mechanisms. Alumina was chosen as the best membrane material for the initial studies.

Present work is directed toward fabricating improved membranes and testing them on a laboratory scale for separating gases of interest. This work is focused on separating and recovering hydrogen. The technical approach is to develop and fabricate membranes with small pores $(<10 \AA)$ and a narrow pore size distribution to take advantage of gas transport mechanisms other than, or in addition to, simple Knudsen diffusion, to provide increased gas selectivity. Lab-scale tests are conducted on the best membranes to measure the permeabilities of components of synthesis gas. Finally, the membrane will be tested with a simulated coal gasification mixture. 


\subsection{Discussion of Current Activities}

A large number of tubular alumina membranes, with a diameter of about $9 \mathrm{~mm}$ and a wall thickness of about $0.5 \mathrm{~mm}$, have been fabricated. The average pore radius of the membranes has been reduced to $<10 \AA$ Gas permeability measurements using some of these membranes were reported previously. ${ }^{23}$ The permeabilities of the membranes were measured at room temperature using helium, nitrogen, and carbon dioxide in the pressure range of 15 to $150 \mathrm{psi}$; nitrogen and helium permeabilities of one membrane sample were measured up to a feed gas pressure of $589 \mathrm{psi}$. In general, the order of permeability was $\mathrm{He}>\mathrm{N}_{2}>\mathrm{CO}_{2}$. In these tests, the membrane was not enclosed and the permeate stream was vented to the atmosphere by closing one end of the membrane tube, thus forcing all of the gas through the membrane. Also, the gas permeabilities of several fabricated alumina membranes were measured using a modified membrane assembly. With this assembly, the permeate gas could be collected and analyzed, and the gas pressure on both the permeate side and the feed side of the membrane could be varied. The membrane assembly contained an epoxy seal, so these tests were also made at room temperature. The average permeabilities of pure helium and pure nitrogen were determined over a range of feed gas pressures up to 170 psig and permeate pressures up to 87 psig.

During this report period, gas permeabilities of a fabricated alumina membrane were measured at higher temperatures. In addition, the alumina membranes were tested for their ability to separate hydrogen from a gas mixture.

\subsection{Permeability Measurements at Higher Temperatures}

The pure gas permeabilities of helium and nitrogen were measured using a fabricated alumina membrane at $200^{\circ} \mathrm{C}$ and $500^{\circ} \mathrm{C}$. The gas flows were calculated for $20^{\circ} \mathrm{C}$ for comparison. For the higher temperature tests, the membrane sample was attached to stainless steel ferrules through a niobium spacer using a brazing technique. The gas flows through the membrane were measured at different feed gas pressures; the permeate gas as vented to the atmosphere. The results were calculated as the gas flux per unit pressure differential across the membrane and referenced to a temperature of $20^{\circ} \mathrm{C}$. The measurements were made sequentially at $20^{\circ}, 200^{\circ}$, and $500^{\circ} \mathrm{C}$. The membrane was then cooled back to $20^{\circ} \mathrm{C}$, and the measurements were repeated. Table 2.2 shows the pressure ranges, the average gas fluxes, and the calculated separation factors based on the ratio of the average gas fluxes of helium and nitrogen, at $20^{\circ} \mathrm{C}$ (before heating), $200^{\circ} \mathrm{C}, 500^{\circ} \mathrm{C}$, and again at $20^{\circ} \mathrm{C}$ (after heating). The 
helium flux increased as the temperature was increased. The nitrogen flux decreased by about $18 \%$ when the membrane was heated to $200^{\circ} \mathrm{C}$ with no significant change when heated further to $500^{\circ} \mathrm{C}$. The fluxes of both gases were significantly higher at $20^{\circ} \mathrm{C}$ after the membrane had been heated to $500^{\circ} \mathrm{C}$. The calculated separation factors increased at the temperature was increased, reaching 2.66 at $500^{\circ} \mathrm{C}$. The ideal Knudsen separation factor is 2.65 .

These results indicate: (1) heating removes water and other adsorbed materials from the pores of the membrane, resulting in higher flow of both gases after the membrane was heated; (2) higher surface adsorption of nitrogen at $20^{\circ} \mathrm{C}$ results in more surface flow and a lower separation factor; and (3) surface adsorption is negligible at higher temperatures, and the separation factors approach the ideal value expected from Knudsen diffusion.

Table 2.2. Comparison of gas fluxes through an alumina membrane at higher temperatures

\begin{tabular}{|c|c|c|c|c|}
\hline \multirow{3}{*}{ Helium } & \multicolumn{4}{|c|}{ Temperature $\left({ }^{\circ} \mathrm{C}\right)$} \\
\hline & $\underline{20^{2}}$ & $\underline{200}$ & $\underline{500}$ & $\underline{20^{b}}$ \\
\hline & & & & \\
\hline Pressure Range (psig) & $35-63$ & $33-66$ & $31-61$ & $29-55$ \\
\hline Avg. Flux $\left(\mathrm{cm}^{3} / \mathrm{min} / \mathrm{psi}\right)$ & 7.82 & 8.23 & 9.78 & 11.7 \\
\hline Nitrogen & & & & \\
\hline Pressure Range & $34-81$ & $35-87$ & $34-89$ & $29-73$ \\
\hline Avg. Flux $\left(\mathrm{cm}^{3} / \mathrm{min} / \mathrm{psi}\right)$ & 4.42 & 3.62 & 3.67 & 6.21 \\
\hline Calculated Separation Factor & & & & \\
\hline$\left(\mathrm{He} / \mathrm{N}_{2}\right)$ & 1.77 & 2.27 & 2.66 & 1.88 \\
\hline
\end{tabular}

Before heating

'After heating

\subsection{Separation of Gas Mixtures}

Two different mixtures of gases were used to simulate coal gasifier synthesis gas products. The compositions of the two mixtures obtained from Matheson Gas Company are shown in Table 2.3. One of the gas mixtures contained hydrogen, carbon monoxide, carbon dioxide, and methane; the second mixture contained these gases, along with nitrogen.

The alumina membranes were tested for their ability to separate hydrogen from the gas mixtures. The membranes were tested at different feed gas pressures, ratios of permeate to residue gas flows, and differential pressures across the membranes. For these tests, the 
Table 2.3. Composition of simulated coal gasifier gas mixtures

\begin{tabular}{lcc}
\hline & \multicolumn{2}{c}{ Content (\%) } \\
\cline { 2 - 3 } Gas & $\frac{\text { Mixture 1 }}{35.30}$ & Mixture 2 \\
Hydrogen & 19.86 & 19.85 \\
Carbon Dioxide & 35.54 & 5.01 \\
Carbon Monoxide & 9.50 & 19.97 \\
Methane & $\ldots .$. & 4.99 \\
Nitrogen & & 50.18 \\
\hline
\end{tabular}

membrane assembly contained epoxy seals, so the tests were made at room temperature. The feed, raffinate, and permeate gas streams were analyzed by gas chromatography. Typically, the pressure on the feed side of the membrane ranged from 65 to $75 \mathrm{psig}$; the permeate pressure ranged from about 23 to 29 psig. The permeate gas was enriched in hydrogen, primarily at the expense of carbon dioxide (reduced carbon dioxide content).

Figure 2.2 compares the chromatograms of the permeate and residue gases from one test using gas Mixture 2. In this test, the feed gas pressure was $66 \mathrm{psig}$, and the permeate

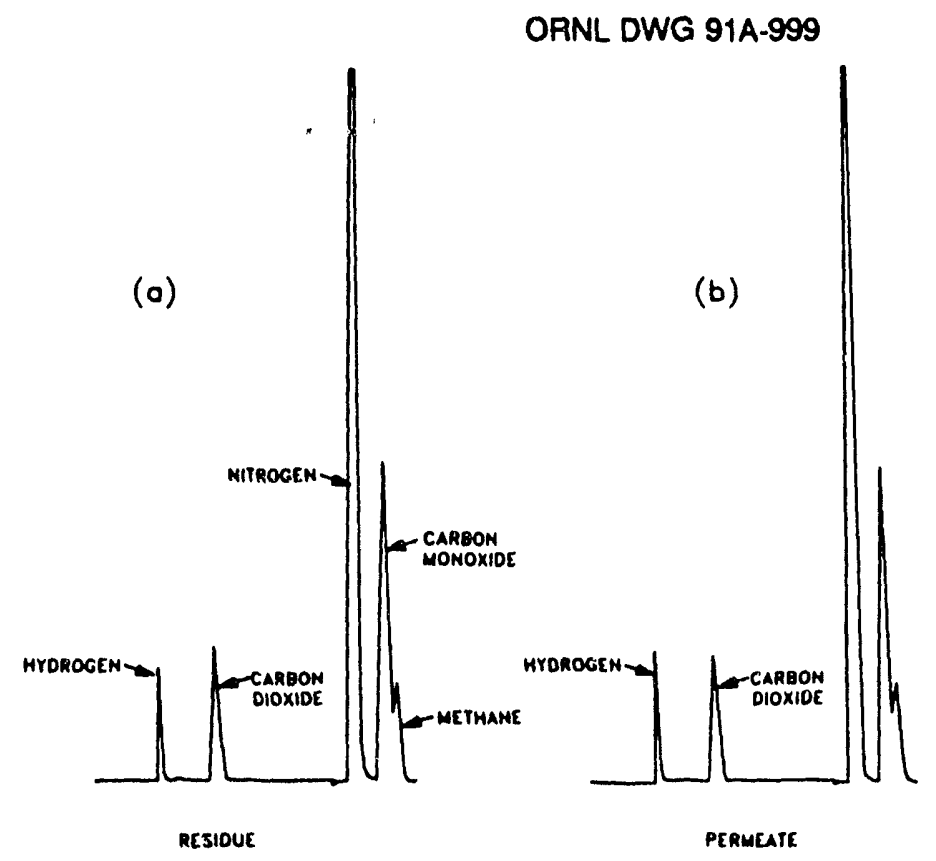

Fig. 2.2. Chromatograms of (a) residue, and (b) permeate gas streams. 
pressure was $50 \mathrm{psig}$, for a differential pressure across the membrane of $16 \mathrm{psig}$. The gas flows were adjusted so that about 15 percent of the gas was allowed to flow through the membrane as permeate. It can be seen that qualitatively, the relative amount of hydrogen compared to carbon dioxide, is higher in the permeate gas and lower in the residue gas. In tests similar to this, the hydrogen content in the permeate gas compared to the feed gas increased from $35.3 \%$ to $45.5 \%$ for Mixture 1, and from $19.85 \%$ to $24.5 \%$ for Mixture 2.

This completes the work on this project. A final report summarizing the results is being prepared.

\subsection{References}

1. B. Z. Egan, Using Inorganic Membranes to Separate Gases: R\&D Status Review, ORNL/TM-11345, Oak Ridge National Laboratory, Oak Ridge, Tennessee, 1989.

2. B. Z. Egan, R. R. Judkins, D. E. Fain, G. E. Roettger, S. P. N. Singh, and D. E. White, "Gas Separations Using Inorganic Membranes," pp. 314-322 in Proceedings of the Tenth Annual Gasification and Gas Stream Cleanup Systems Contractors Review Meeting, V. P. Kothari and J. L. Beeson, ed., Morgantown Energy Technology Center, Morgantown, West Virginia, Vol. I, 1990.

3. B. Z. Egan, D. E. Fain, G. E. Roettger, and D. E. White, "Separating Hydrogen from Coal Gasification Gases with Alumina Membranes," presented at the ASME International Gas Turbine and Aeroengine Congress and Exposition, Orlando, Florida, June 1991. Preprint No. 91-GT-132.

\section{MICROWAVE SINTERING OF MATERIALS FOR FUEL CELLS - M. A. Janney} and H. D. Kimrey

In the last semiannual report, it was shown that lanthanum chromite is easy to fire in a

$2.45 \mathrm{GHz}$ microwave furnace. It couples well because of its relatively low electrical resistivity ( $0.1 \mathrm{ohm}-\mathrm{cm}$ at ambient temperature). However, no "microwave effect" was observed for the system studied. There was no acceleration of densification or microstructural development in the system produced by microwave firing. This was in marked contrast to the large "microwave effects" that had been observed previously in systems such as alumina and zirconia. The absence of a "microwave effect" in lanthanum chromite is attributed to the way that microwaves couple to it. In the chromite system, coupling is to the electrons, which do not participate in diffusion. In the alumina and zirconia systems, coupling is to the ionic defects in the crystal, which are directly responsible for diffusion.

An investigation of the role that ionic and electronic conductivity play in determining the "microwave effect" has been initiated. The model system that is being investigated is based 
on the $\mathrm{ZrO}_{2}-\mathrm{CeO}_{2}$ system. This system has two properties that make it attractive for study: (1) its total electrical conductivity can be varied over several orders of magnitude; and, (2) its conductivity can be altered from being predominantly ionic to predominantly electronic in nature. We will synthesize several different compositions in the $\mathrm{ZrO}_{2}-\mathrm{CeO}_{2}-\mathrm{Y}_{2} \mathrm{O}_{3}$ system. The addition of $\mathrm{Y}_{2} \mathrm{O}_{3}$ to the system provides a means to fix the level of ionic conductivity in the system by the creation of oxygen vacancies. This will allow us to work in a convenient range of conductivities to assure that we examine a wide variation in the ionic to electronic conductivity ratio. Yttria levels between 0.1 and 3 mol\% and ceria levels between 10 and $15 \mathrm{~mol} \%$ will be examined.

\subsection{Experimental Procedure}

We have focused on developing the microwave experimental procedures required to repeatability fire $\mathrm{CeO}_{2}$ - doped $\mathrm{ZrO}_{2}$ ceramics in the microwave furnace under controlledatmosphere conditions. Our major concerns include the proper control of the atmosphere around the sample, appropriate thermal insulation systems, and chemical compatibility of the insulation system with the samples to be microwave fired.

Numerous insulation systems have been evaluated. In all cases, a "picket fence" arrangement of $\mathrm{SiC}$ rods has been used because of the need for "indirect" heating of the $\mathrm{CeO}_{2}$ - doped $\mathrm{ZrO}_{2}$ at temperatures below $\sim 70{ }^{\circ} \mathrm{C}$. (The usefulness of the "picket fence" in the sintering of zirconia was demonstrated previously in this project.) The most promising insulation systems are based on a three-part arrangement of the components, Fig. 2.3.

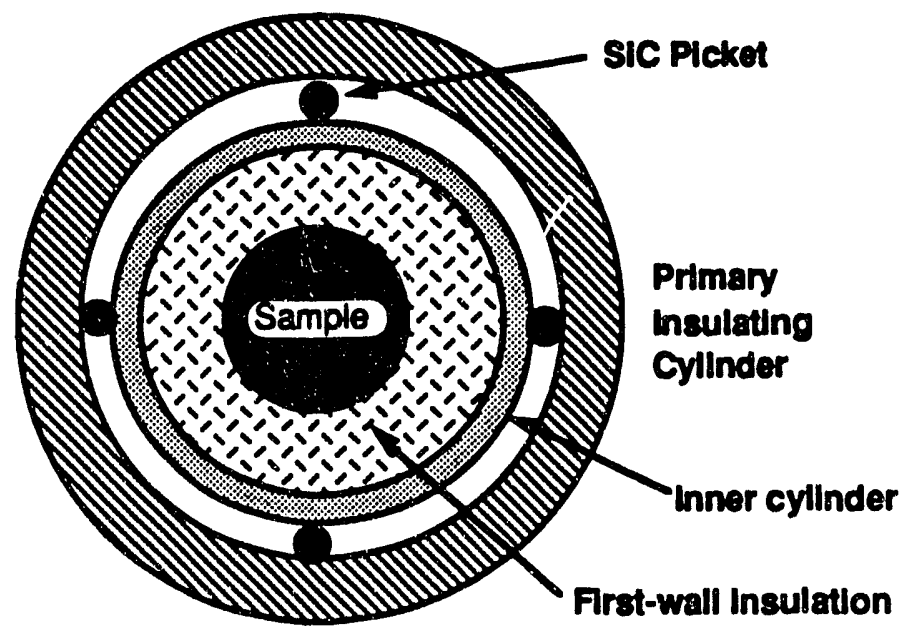

Figure 2.3. Schematic of "picket fence" insulation system for $\mathrm{ZrO}_{2}$ microwave sintering. 
The first wall insulation is the most important component of the insulation system. It must perform several tasks if the insulation system is to be considered successful. First, it must be chemically compatible with the $\mathrm{CeO}_{2}$ - doped $\mathrm{ZrO}_{2}$ samples. This eliminates the use of commercial zirconia bulk fiber, which is doped with $8 \mathrm{~mol} \% \mathrm{Y}_{2} \mathrm{O}_{3}$. During thermal processing, diffusion of the $\mathrm{Y}_{2} \mathrm{O}_{3}$ into the $\mathrm{CeO}_{2}$ - doped $\mathrm{ZrO}_{2}$ sample would invalidate our experiments by changing the conductivity of the sample in an uncontrolled manner. Second, the first-wall insulation must have dielectric properties similar to those of the sample. Third, it must be a good thermal insulator.

Two approaches were taken to achieve the goals outlined above. First, $\mathrm{ZrO}_{2}-12 \mathrm{~mol} \%$ $\mathrm{CeO}_{2}$ powder was consolidated and pre-fired to form -10 mesh granules. these were poured around the sample to form the first-wall insulation. This approach worked passably well, but some problems were encountered with sample cracking during sintering. A better first-wall insulation was made by mixing $\mathrm{ZrO}_{2}-12 \mathrm{~mol} \% \mathrm{CeO}_{2}$ powder with bulk alumina fiber insulation in a 3:1 ratio by weight. This material had better insulating properties than the granulated $\mathrm{ZrO}_{2}-12 \mathrm{~mol} \% \mathrm{CeO}_{2}$ powder and eliminated cracking. Both of these approaches have the advantage that they provide an insulation that is with the sample and that matches the dielectric response of the sample. Also, as the composition of the sample is changed, by selective doping with yttria, the chemical composition of the insulation can be readily changed as well. Using the zirconia-alumina fiber mixture along with the "picket fence" arrangement, an initial series of sintering experiments was completed.

\subsubsection{Results and Discussion}

Our working hypothesis is that there should be differences in the heating and sintering of $\mathrm{CeO}_{2}$ - doped $\mathrm{ZrO}_{2}$ fired in different atmospheres. These differences in heating exist because of the relative ratio of electronic to ionic conductivity. The firing curves shown in Figure 2.4 confirm that there are significant differences in the heating of $\mathrm{CeO}_{2}$ - doped $\mathrm{ZrO}_{2}$ fired in air and in $\mathrm{Ar}-\mathrm{H}_{2}$.

The microwave power curve for the sample fired in air shows behavior that is typically observed in the firing of alumina or zirconia ceramics using the picket fence arrangement. At low temperatures, the power increases with increasing temperature. This indicates that the microwaves are coupling to the $\mathrm{SiC}$ rods and are heating the zirconia indirectly by radiation and conduction. As the temperature increases, the amount of microwave power absorbed by the zirconia relative to the $\mathrm{SiC}$ rods increases. Eventually, all of the heating will be by direct 


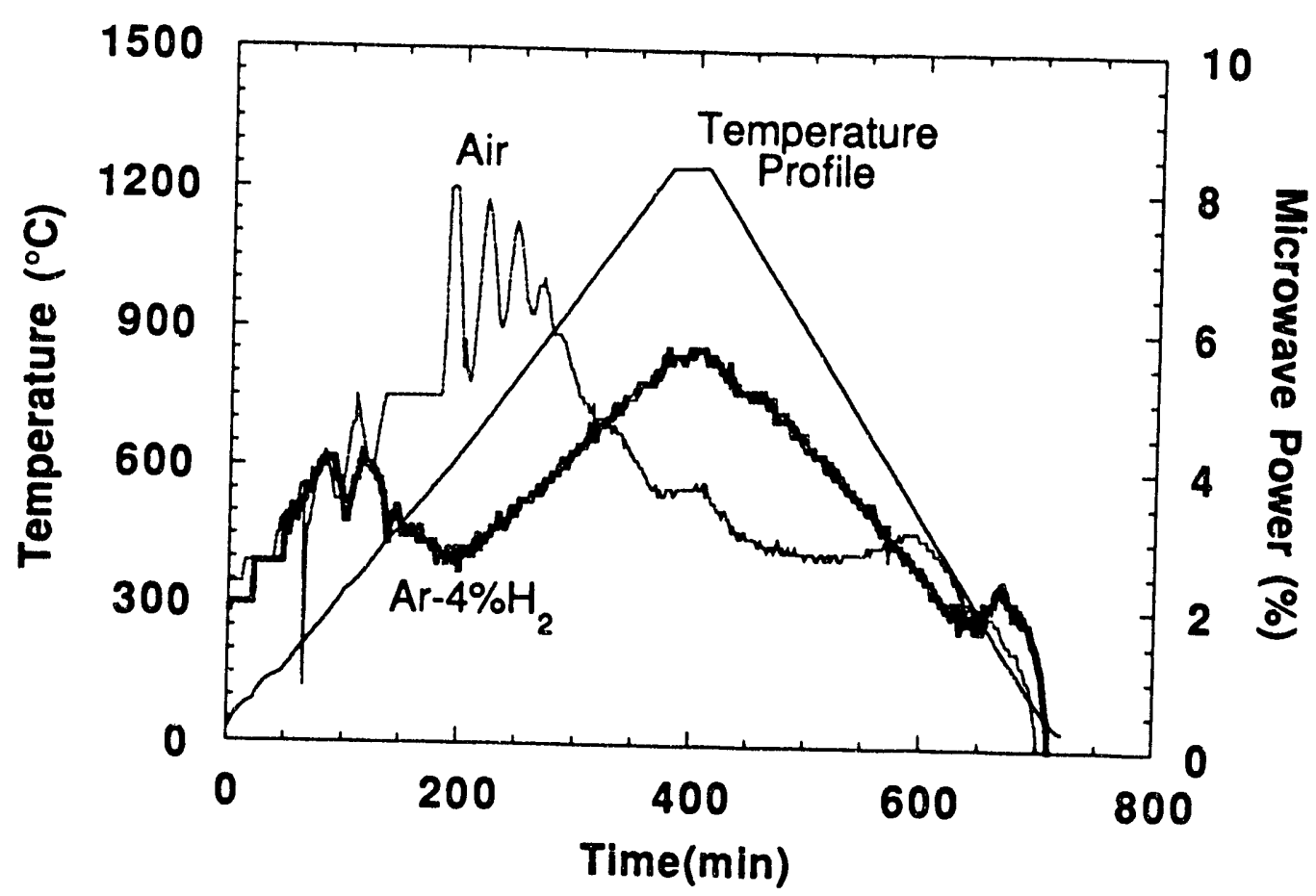

Figure 2.4. The microwave heating profiles for $\mathrm{ZrO}_{2}-12 \mathrm{~mol} \% \mathrm{CeO}_{2}$ fired in air and in $\mathrm{Ar}-4 \% \mathrm{H}_{2}$ were significantly different.

microwave heating of the zirconia. At about $700^{\circ} \mathrm{C}$, the total power starts to decrease. At this point,virtually all of the microwave power is being absorbed by the zirconia sample. As the sample heats further, the efficiency with which it is heated by the microwaves increases. This increase in efficiency is caused by the increase in dielectric loss tangent of the zirconia with temperature. Above $\sim 900^{\circ} \mathrm{C}$, the power steadily drops until a plateau is reached at the sintering temperature of $1250^{\circ} \mathrm{C}$. Samples fired in air were white in color after firing, indicating that the sample was fully oxidized.

The microwave power curve for the sample fired in $\mathrm{Ar}-4 \mathrm{H}_{2}$ is quite different from that for firing in air. At temperatures up to $\sim 300^{\circ} \mathrm{C}$, there is a similar increase in power. However, above $300^{\circ} \mathrm{C}$, the sample fired in $\mathrm{Ar}-4 \mathrm{H}_{2}$ shows a decrease in power up to $\sim 600^{\circ} \mathrm{C}$. This is followed by a monotonic increase in power up to the sintering temperature of $1250^{\circ} \mathrm{C}$. At temperatures below $\sim 1000^{\circ} \mathrm{C}$ the $\mathrm{Ar}-4 \mathrm{H}_{2}$ sample requires less power than the air sample; in contrast, above $1000^{\circ} \mathrm{C}$, it requires more power. Samples fired in $\mathrm{Ar}-4 \mathrm{H} 2$ were dark gray in color indicating that some of the $\mathrm{Ce}^{+4}$ had been reduced to $\mathrm{Ce}^{+3}$.

What particular mechanisms cause the differences between the air and the $\mathrm{Ar}-4 \mathrm{H}_{2}$ cases have not been determined so far. The change in color indicates that there should be 
significant electronic conductivity in the samples fired in $\mathrm{Ar}-4 \% \mathrm{H}_{2}$. Determination of the dielectric properties of these materials at microwave frequencies would be helpful. We will attempt to get those measurements made during the coming semi-annual period.

\subsection{Summary and Conclusions}

Microwave firing of $\mathrm{ZrO}_{2}-12 \mathrm{~mol} \% \mathrm{CeO}_{2}$ in air and in $\mathrm{Ar}-4 \% \mathrm{H} 2$ showed very different trends. Air firing followed behavior similar to that previously observed for $\mathrm{ZrO}_{2}-8 \mathrm{~mol} \%$ $\mathrm{Y}_{2} \mathrm{O}_{3}$ and alumina. Firing in $\mathrm{Ar}-4 \% \mathrm{H}_{2}$ deviated significantly from previous experience for zirconia. The differences are thought to be because the reduced samples had higher electronic conductivity.

\section{ENVIRONMENTAL EFFECIS ON IRON ALUMINIDES - J. H. DeVan}

Alloys based on the long-range-ordered system $\mathrm{Fe}_{3} \mathrm{Al}$ are under development at Oak Ridge National Laboratory in support of coal conversion and combustion materials requirements [see ORNL-2(F)]. Of particular interest is the performance of these alloys in coal gasifiers involving product gases with relatively low oxygen activities $\left(10^{-20} \mathrm{~atm}\right)$ and high sulfur activities $\left(10^{-8} \mathrm{~atm}\right)$. Using $\mathrm{H}_{2} \mathrm{~S}-\mathrm{H}_{2}-\mathrm{H}_{2} \mathrm{O}$ gas mixtures, several experimental iron-aluminum alloys have been tested to assess the effects of aluminum concentration on corrosion behavior at 700 to $800^{\circ} \mathrm{C}$ in a simulated gasifier environment. Thermogravimetric analyses (TGA), together with metallographic and chemical analyses of the corrosion product scales, are performed to determine the role of respective metallic elements on oxidation and sulfidation processes. Additionally, the corrosion resistance of $\mathrm{Fe}_{3} \mathrm{Al}$ alloys is being evaluated by exposures at 600 to $900^{\circ} \mathrm{C}$ in the gas-cooler section of an operating gasifier in the United Kingdom.

Studies of $\mathrm{Fe}_{3} \mathrm{Al}$-bases alloys are also being conducted in air at 800 to $1000^{\circ} \mathrm{C}$ to characterize the oxidation properties of the alloys in more oxidizing environments typical of coal-fired boilers and air preheaters. Mechanisms controlling the nucleation, growth, and exfoliation of oxide scales are characterized by TGA, electron microscopy, and secondary ion mass spectrometry. The latter technique is used in conjunction with ${ }^{18} \mathrm{O}$ labeling to determine the species and transport paths contributing to oxide growth.

\subsection{Air Oxidation Behavior of $\mathrm{Fe}_{3} \mathrm{Al}$ Alloys}

Weight change data for $\mathrm{Fe}_{3} \mathrm{Al}$ alloys tested in dry air were collected and analyzed to assess the effects of alloying additions on high temperature oxidation behavior. The data were 
obtained under isothermal conditions in slowly moving dry air for exposures up to $200 \mathrm{~h}$. Test specimens were in the form of $16 \times 76 \times 1 \mathrm{~mm}$ coupons, and all surfaces were mechanically ground with 600 -grit abrasive before exposure. Following exposure the coupons were visually checked for detachment of corrosion products scales, and selected specimens were then analyzed by optical imaging of a polished cross section and, in some cases, by scanning electron microscopy with associated energy dispersive $\mathrm{x}$-ray analysis (EDX).

Weight change data from exposures of iron aluminides to $800^{\circ} \mathrm{C}$ air are shown in Fig. 2.5. Although all the measured weight gains were relatively small, the eight weight change curves of Fig. 2.5 tend to divide into two groupings. The lower grouping consists of the three $\mathrm{Fe}-28 \mathrm{Al}$ coupons and one composed of $\mathrm{Fe}-28 \mathrm{Al}-2 \mathrm{Cr}$, while the higher group includes two specimens of $\mathrm{Fe}-28 \mathrm{Al}-4 \mathrm{Cr}-0.1 \mathrm{~B}$ and one each of $\mathrm{Fe}-28 \mathrm{Al}-6 \mathrm{Cr}$ and

Fe-10Cr-0.1Zr-0.05B-0.5Nb-0.5Mo-0.02Y. The weight gains were not significantly affected by additions of minor alloying elements $(\leq 0.1$ at.\%) or variations between 4 and 10 at.\% chromium. The chromium concentration also affected the measured parabolic rates constants,

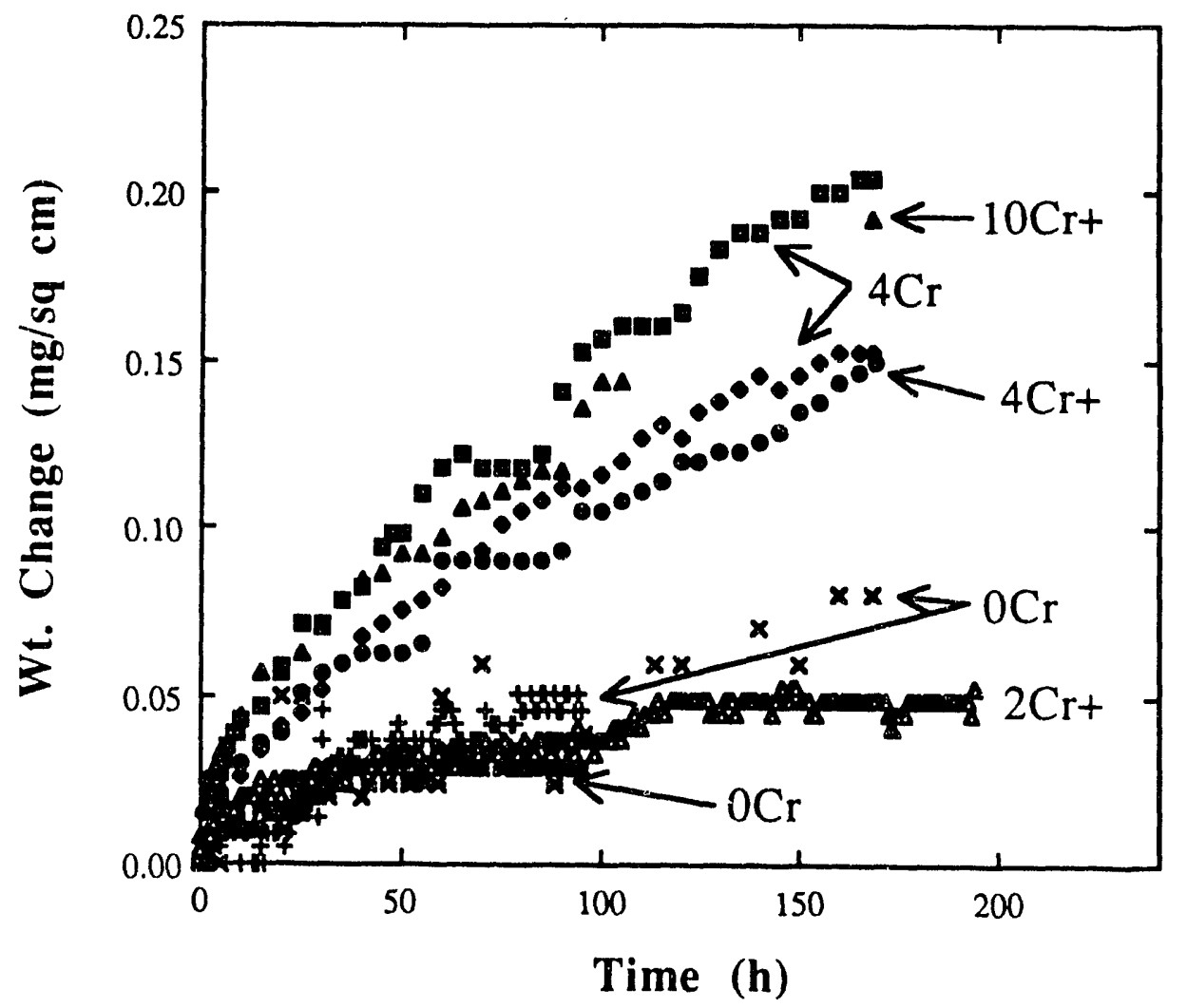

Fig. 2.5. Weight gains of $\mathrm{Fe}_{3} \mathrm{Al}$ alloys $(28 \mathrm{at} . \% \mathrm{Al}$ ) during exposure to dry air at $800^{\circ} \mathrm{C}$. Cr concentrations are in at. $\%$. 
$k_{p}$ as determined by the quotient $(\Delta w)^{2} / t$ where $\Delta w$ is the change in weight per unit surface area after exposure for time $t$ (see Table 2.4). The $k_{p}$ values for the iron aluminides with 24 at.\% chromium were approximately a factor of 10 greater than those for $\mathrm{Fe}-28 \mathrm{Al}-(0-2 \mathrm{Cr})$. For comparison, the weight gains and parabolic rate constant of $\mathrm{FeCrAl}$ alloys (discussed in the next section) were also measured and found to be comparable to those of the $\mathrm{Fe}_{3} \mathrm{Al}$ alloys with lower concentrations of chromium (see Table 2.4).

Table 2.4. Parabolic rate constants determined for $\mathrm{Fe}_{3} \mathrm{Al}$ alloys and $\mathrm{FeCrAl}$ in dry air at $800^{\circ} \mathrm{C}$

\begin{tabular}{lc}
\hline Alloys & $\begin{array}{c}\mathrm{kp}^{\mathrm{b}} \\
\left(\mathrm{mg}^{2} / \mathrm{cm}^{4} . \mathrm{h}\right)\end{array}$ \\
\hline $28 \mathrm{Al}$ & $2.3-1.1 \times 10^{-5}$ \\
$28 \mathrm{Al}-2 \mathrm{Cr}$ & $1.3 \times 10^{-5}$ \\
$28 \mathrm{Al}-4 \mathrm{Cr}$ & $1.8-0.7 \times 10^{-4}$ \\
$28 \mathrm{Al}-10 \mathrm{Cr}$ & $2.0 \times 10^{-4}$ \\
$20 \mathrm{Cr}-12 \mathrm{Al}$ & $1.5 \times 10^{-5}$ \\
\hline
\end{tabular}

At $900^{\circ} \mathrm{C}$, the effect of chromium on the oxidation behavior of $\mathrm{Fe}_{3} \mathrm{Al}$ in air was less pronounced than at $800^{\circ} \mathrm{C}$. As shown in Fig. 2.6, increasing the chromium concentration of $\mathrm{Fe}_{3} \mathrm{Al}$ alloys led to a more rapid weight gain during initial exposure. However, there was no significance influence on the oxidation rate after about $100 \mathrm{~h}$. The parabolic rate constants (calculated from curve fits over the entire exposure range) fell within a range of 5-10 $\times 10^{-5}$ $\mathrm{mg}^{2} / \mathrm{cm}^{4} / \mathrm{h}$ and did not vary monotonically with chromium concentration. The FeCrAl alloys showed weight changes similar to the $\mathrm{Fe}_{3} \mathrm{Al}$ alloys at $900^{\circ} \mathrm{C}$.

As expected from the small weight gains, the scales that formed on the oxidized $\mathrm{Fe}_{3} \mathrm{Al}$ alloys were quite thin and difficult to image and characterize. Examination of polished cross sections of selected iron aluminides oxidized at $900^{\circ} \mathrm{C}$ and air-cooled revealed that only a fraction of an exposed surface retained pieces of the scale. EDX analysis of the thin, detached strip revealed only aluminum, which is consistent with the formation of an $\mathrm{Al}_{2} \mathrm{O}_{3}$ scale formed during high temperature exposure. (The $x$-ray system was not capable of detecting the oxygen in the scale.)

These results show that while chromium in $\mathrm{Fe}_{3} \mathrm{Al}$ (up to 10 at.\%) does not exert a large influence on air oxidation resistance there is a discernible effect at concentrations of $4 \%$ and above. At $800^{\circ} \mathrm{C}$, this was manifested by faster oxygen uptake during the initial stages of 


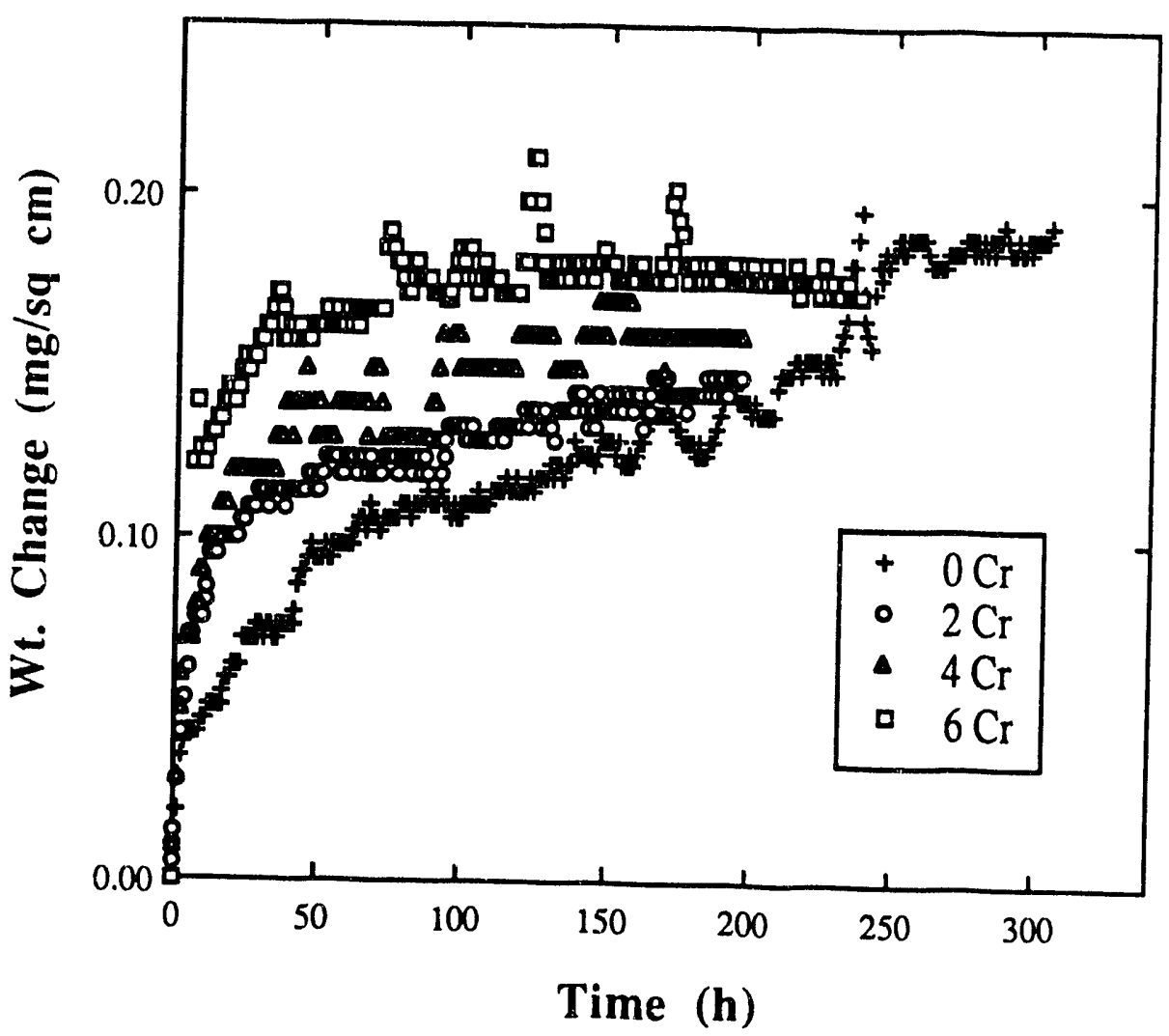
Fig. 2.6. Weight gains of $\mathrm{Fe}_{3} \mathrm{Al}$ alloys $(28$ at.\% $\mathrm{Al})$ during exposure at dry air at $900^{\circ} \mathrm{C}$.
Cr concentrations are in at.\%.

exposure and overall higher parabolic rate constants (Fig.2.5). At $900^{\circ} \mathrm{C}$, there was no apparent difference in rate constants for the $\mathrm{Fe}_{3} \mathrm{Al}$ with various levels of chromium, but the amount of mass gain during the initial stages of oxidation was directly proportionai to the chromium concentration (Fig. 2.6). Therefore, it appears that the presence of this element in amounts greater than $2 \%$ leads to more rapid formation of an $\mathrm{Al}_{2} \mathrm{O}_{3}$ surface product. Under certain circumstances such an effect could prove beneficial if it acted to more quickly establish an external protective oxide layer prior to exposure to more aggressive or deleterious (hydrogen sulfide-containing) environments. Indeed, it has been hypothesized that the beneficial effect of chromium additions on room temperature ductility of iron aluminides ${ }^{1}$ may relate to an oxidation effect during high temperature treatment such that the scale that forms then serves a better barrier to hydrogen uptake by the alloy at ambient conditions ${ }^{2}$.

Because $\mathrm{FeCrAl}$ is also an alumina-former under the oxidation conditions of this study, it is not unexpected that it shows comparable oxidation rates to that of $\mathrm{Fe}_{3} \mathrm{Al}$ (see Table 2.4). However, the ability of $\mathrm{FeCrAl}$ alloys (containing about 7-12 at.\% $\mathrm{Al}$ ) to form $\mathrm{Al}_{2} \mathrm{O}_{3}$ critically 
depends on the presence of substantial amounts of chromium, which promotes the lateral growth of this surface product. ${ }^{3,4}$ In the case of $\mathrm{Fe}_{3} \mathrm{Al}$ alloys, the aluminum levels of the aluminide are vell in excess of the critical concentration needed for external $\mathrm{Al}_{2} \mathrm{O}_{3}$ formation, even in the absence of chromium.

\section{Corrosion in $\mathrm{H}_{2} \mathrm{~S}-\mathrm{H}_{2}-\mathrm{H}_{2} \mathrm{O}$ Gas Mixtures}

As shown in earlier reports ${ }^{5,6}$ alloying with chromium (above $2 \%$ ) significantly reduces the corrosion resistance of $\mathrm{Fe}_{3} \mathrm{Al}$-based alloys to high temperature $\mathrm{H}_{2} \mathrm{~S}-\mathrm{H}_{2}-\mathrm{H}_{2} \mathrm{O}$ gas mixtures. To examine further the interplay between aluminum and chromium in mixed gas at relatively low oxygen pressures, it is of interest to compare the behavior of the FeCrAl (Fe-18 wt.\% $\mathrm{Cr}-6 \mathrm{wt} \% \mathrm{Al}$ ) alloy syst em with $\mathrm{Fe}_{3} \mathrm{Al}$ alloys containing chromium. Three developmental $\mathrm{FeCrAl}$ alioys, whose compositions are listed in Table 2.5, were obtained from Harwell Laboratory and were exposed to a reference $\mathrm{H}_{2} \mathrm{~S}-\mathrm{H}_{2}-\mathrm{H}_{2} \mathrm{O}$ gas mixture $\left(\mathrm{pO}_{2}=10^{-216}\right.$ atm and $\mathrm{pS}_{2}=10^{-6}$ ) atm at $800^{\circ} \mathrm{C}$, conditions that had been used previously to evaluate the effects of chromium on $\mathrm{Fe}_{3} \mathrm{Al}$ alloys.

Table 2.5. Compositions of FeCrAl Alloys Supplied by Harwell Laboratory.

\begin{tabular}{ccccccc}
\hline \multicolumn{7}{c}{ Elemental Concentrations (atom \%) } \\
Alloy & $\mathrm{C}$ & $\mathrm{Si}$ & $\mathrm{Cr}$ & $\mathrm{A}$ & $\mathrm{Mn}$ & $\mathrm{Ni}$ \\
\hline VB1852 & 0.074 & 0.41 & 20.3 & 9.11 & 0.38 & 0.24 \\
VB1901 & 0.060 & 1.64 & 21.4 & 10.1 & 0.53 & 0.07 \\
VB1902 & 0.085 & 4.09 & 21.7 & 9.47 & 0.53 & 0.08 \\
\hline
\end{tabular}

Weight changes for the respective alloys are shown in Fig. 2.7. Included for comparison are results for the largest chromium addition (10 at.\%) that has made to the $\mathrm{Fe}_{3} \mathrm{~A}$ alloy. The weight gain over a $24-\mathrm{h}$ period is seen to exceed $30 \mathrm{mg} / \mathrm{cm}^{2}$ in the case of the $\mathrm{FeCrAl}$ alloys compared to a gain of $3 \mathrm{mg} / \mathrm{cm}^{2}$ for the $\mathrm{Fe}_{3} \mathrm{Al}$-based alloy. (Weight gains for $\mathrm{Fe}_{3} \mathrm{Al}$ alloys with $2 \%$ or less chromium are on the order of $0.2 \mathrm{mg} / \mathrm{cm}^{2}$ over the same time period.) The resistance to sulfidation in "reducing" mixed gases gained by aluminum additions to iron-based alloys, as compared with chromium additions, served as the early impetus for the development of $\mathrm{Fe}_{3} \mathrm{Al}$-based alloys. ${ }^{7}$ The data in Fig. 2.7 again snow the advantages of the higher aluminum 
concentrations afforded by $\mathrm{Fe}_{3} \mathrm{Al}$, even when chromium is also present. The beneficial effect of aluminum is even evident in comparisons of the $\mathrm{FeCrAl}$ alloys. Although corrosion rates are nearly the same for the three alloys tested, there is a consistent decrease in rate as the aluminum content increases. Furthermore, the addition of 4.1 at.\% silicon to one of the alloys did not override this effect of aluminum.

ORNL-DWG 90-10250

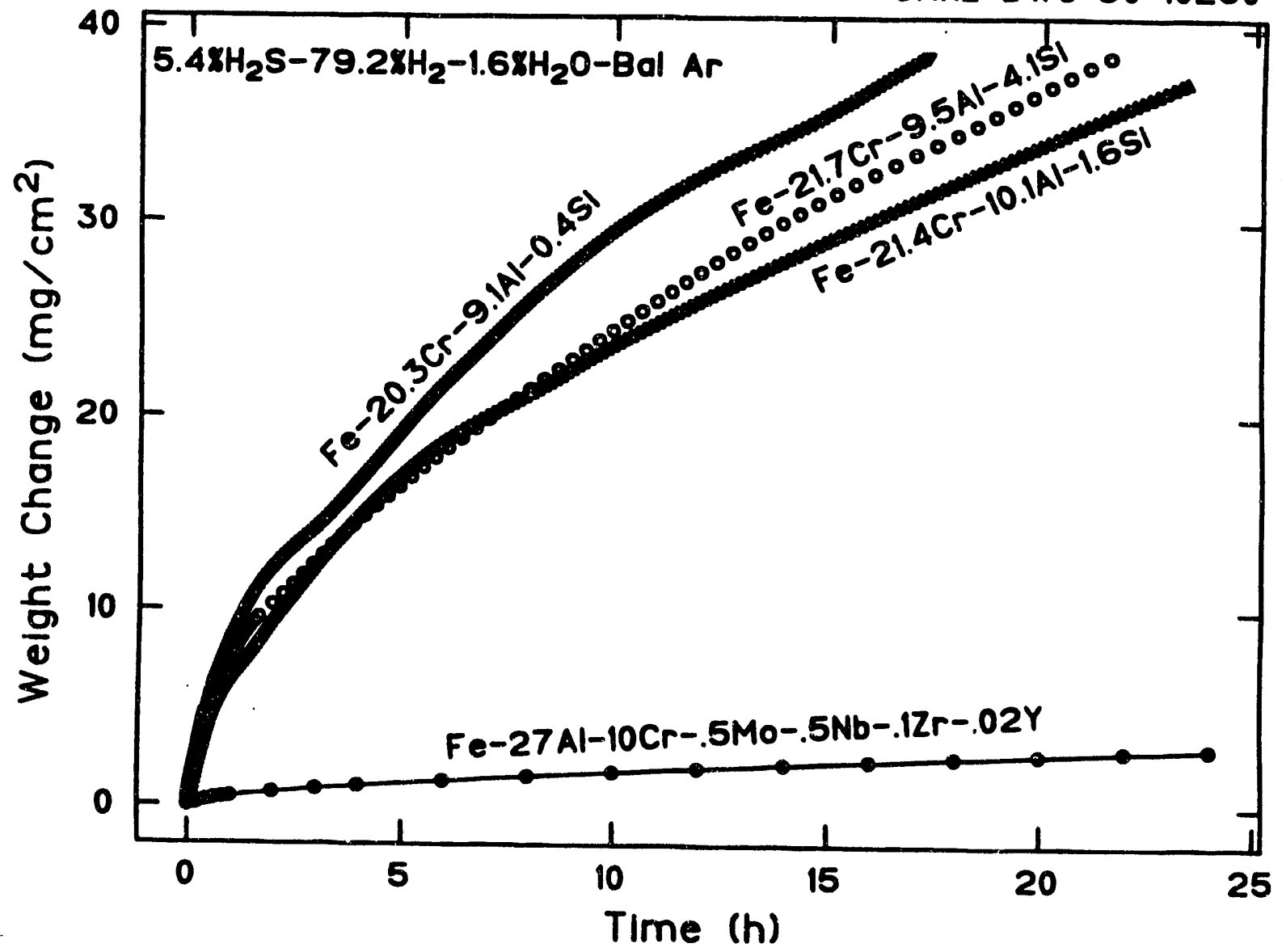

Fig. 2.7. Weight gains of $\mathrm{FeCrAl}$ alloys (upper curves) compared with $\mathrm{Fe}_{3} \mathrm{Al}$ alloy containing $10 \mathrm{At} \% \mathrm{Cr}$ (lower curve) during exposure to $\mathrm{H}_{2}-\mathrm{H}_{2}-\mathrm{H}_{2} \mathrm{O}$ gas mixture at $800^{\circ} \mathrm{C}$.

Aqueous corrosion studies of $\mathrm{Fe}_{3} \mathrm{Al}$-based alloys have shown that the addition of 1 to 2 at.\% Mo significantly increases the resistance of the alloy to attack in acid chloride solutions. $^{8}$ These same alloys have now been evaluated in high temperature $\mathrm{H}_{2} \mathrm{~S}-\mathrm{H}_{2}-\mathrm{H}_{2} \mathrm{O}$ gas mixtures to determine the effect of the molybdenum alloying addition on sulfidation/oxidation resistance. The alloys, containing 2 at.\% molybdenum with 0 and 4 at.\% $\mathrm{Cr}$, respectively, were exposed at $800^{\circ} \mathrm{C}$, and the weight change results, shown in Fig. 2.8, indicate significantly 
reduced corrosion rates compared with chromium-containing alloys with no molybdenum. Minor alloying additions of zirconium and zirconium plus yttrium also appear to improve the corrosion resistance of the chromium-containing alloy, but to a much lesser degree than the $2 \%$ Mo addition. In the absence of chromium, the $2 \%$ molybdenum alloy gained essentially the same weight after $168 \mathrm{~h}$ as $\mathrm{Fe}_{3} \mathrm{Al}$-based alloys containing $2 \%$ or less chromium (not shown in Fig. 2.8). Thus, the molybdenum addition is effective in suppressing the adverse effect of the $4 \% \mathrm{Cr}$ addition but does not contribute to the innate corrosion resistance of $\mathrm{Fe}_{3} \mathrm{Al}$.

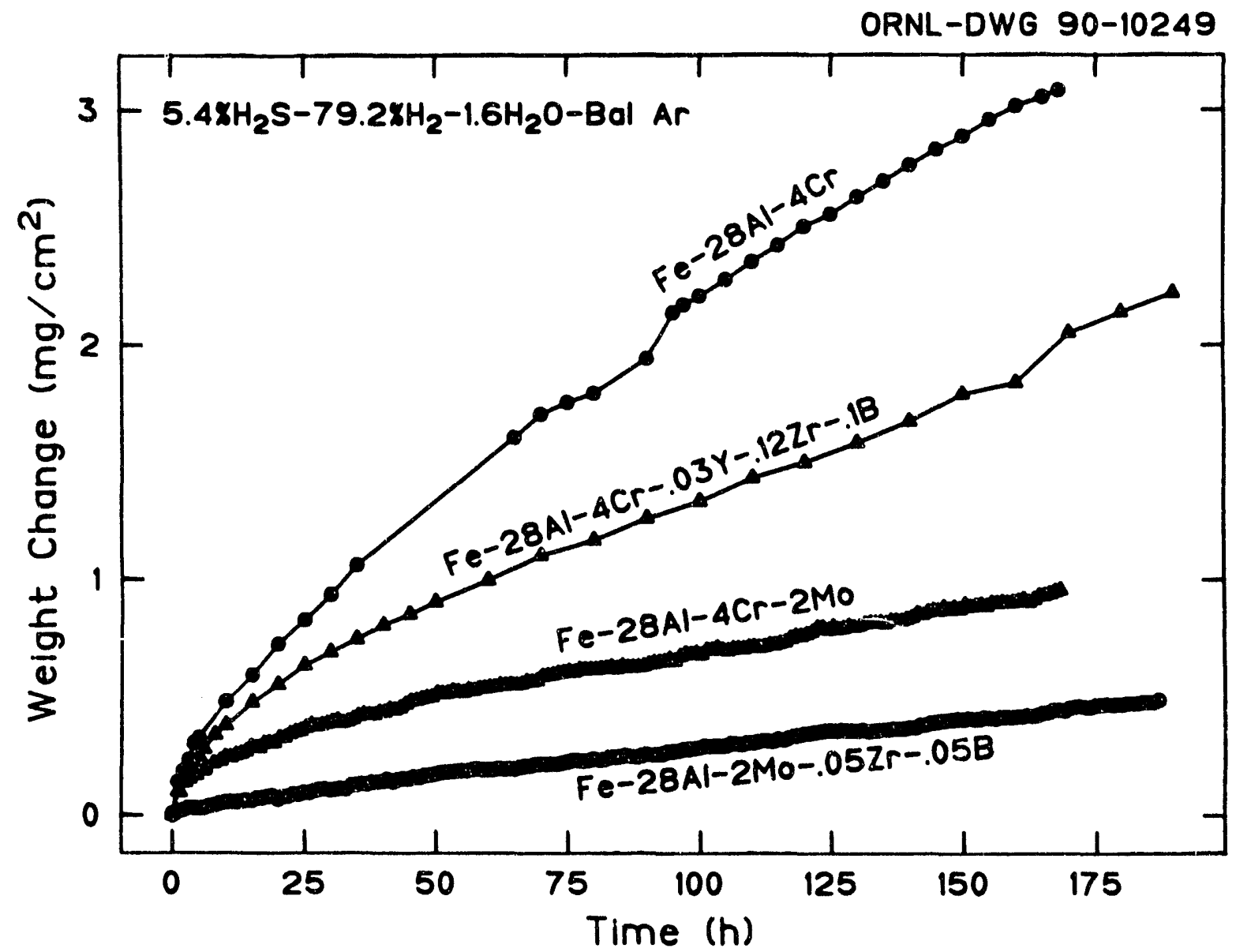

Fig. 2.8. Effect of $\mathrm{Cr}$ and $\mathrm{Mo}$ additions on weight gains of $\mathrm{Fe}_{3} \mathrm{Al}$ alloys exposed to $\mathrm{H}_{2} \mathrm{~S}-\mathrm{H}_{2}-\mathrm{H}_{2} \mathrm{O}$ gas mixture at $800^{\circ} \mathrm{C}$.

\subsection{References}

1. C. G. McKamey, J. A. Horton, and C. T. Liu, J. Mater. Res., 4 (1989) 1156.

2. C. G. McKamey and C. T. Liu, Scripta Metall., 24 (1990) 2119. 
3. W. C. Hagel, Corrosion, 21 (1965) 316.

4. G. H. Meier, T. Grovstein, and J. Doychak (eds.), p. 1 in Oxidation of High-Temperature Intermetallics, TMS, Warrendale, Pennsylavnia, 1989.

5. J. H. DeVan, T. Grobstein, and J. Doychak (eds.), p. 107 in Oxidation of High-Temperature Intermetallics, TMS, Warrendale, Pennsylvania, 1989.

6. J. H. DeVan, p. 299 in Proceedings of the Fourth Annual Conference on Fossil Energy Materials, Conf. 900546, U.S. Department of Energy, Oak Ridge, Tennessee, August 1990.

7. J. H. DeVan, H. S. Hsu, and M. Howell, Sulfidation/Oxidation Properties of Iron-Based Alloys Containing Niobium and Aluminum, ORNL/TM-11176, Oak Ridge National Laboratory, Oak Ridge, Tennessee, May 1989.

8. R. A. Buchanan and J. G. Kim, Aqueous Corrosion Characteristics and Corrosion-Related Cracking Susceptibilities of Fe,Al-Type Iron Aluminides, ORNL/Sub/88-07685CT92/01, University of Tennessee, Knoxville, Tennessee, April 1991.

\subsection{INVESTIGATION OF AUSTENITIC ALLOYS FOR ADVANCED HEAT RECOVERY AND HOT-GAS CLEANUP SYSTEMS - R. W. Swindeman}

The purpose of this activity is to evaluate austenitic alloys for the design, construction, and reliable operation of advanced steam cycle power plants, combined cycle power plants, and hot-gas cleanup systems for pressurized fluidized bed combustors and gasifiers. Depending upon the particulars, the performance requirements for structural materials vary significantly from one application to the next. Sometimes strength and fabricability are important. Other times corrosion resistance is most important. Advances in materials science relating composition and microstructure of austenitic alloys to their high-temperature mechanical properties, stability, and corrosion resistance have made it attractive to tailor alloys and combinations of alloys to meet specific missions. Applications of interest include superheater and reheater tubing for power boilers, ${ }^{1}$ main steam line piping for higher efficiency steam plants, ${ }^{2}$ very high temperature and pressure steam lines for topping cycles, ${ }^{3}$ and materials of construction for hot-gas cleanup systems. ${ }^{4}$ Under consideration are both new and old alloys. Research includes joining methods, high temperature design methodology, and life prediction methods. ${ }^{5}$ These are subjects of great concern in all applications. The investigations cover four categories of materials: lean stainless steels containing less than $20 \%$ chromium (which possess good strength), higher chromium iron base alloys (which possess good corrosion resistance), high chromium nickel base alloys (cladding alloys), and aluminum-bearing alloys (which possess excellent corrosion resistance). ${ }^{5}$ 


\subsection{Lean Stainless Steels}

To meet the requirements for tubing in an advanced boiler superheater, it was expected that a candidate alloy should possess nearly twice the creep strength of the best of the commercial 300 series austenitic stainless steels. ${ }^{5}$ Steels meeting this criterion usually contain MC-forming elements such as titanium, niobium, and vanadium. Often nitrogen is added, as well. Several of these commercial, near-commercial, and developmental alloys were evaluated over a six year period, and the findings were reported in $1990 .^{6}$

Most of the research on the lean stainless steels for superheater tubing has been completed. A few long-time tests remain in progress, and times have exceeded $50,000 \mathrm{~h}$ at $700^{\circ} \mathrm{C}$. The steels continue to show excellent strength and ductility.

One limitation of the HT-UPS steels developed by Maziasz ${ }^{7}$ was the need to cold or warm work the alloys in order to promote the strengthening mechanisms. This treatment also raised the yield strength so that advantage could be taken of the creep strength in setting design stresses for service below $650^{\circ} \mathrm{C}$. An alternate method to increase the yield strength involves nitrogen additions, ${ }^{6}$ hence the long time strength and ductility of nitrogen containing alloys is of interest. To this end, additional studies were undertaken in this reporting period to examine nitrogen-strengthened type 316 stainless steel.

Main steam line piping was obtained from the A. M. Williams Plant. The material was type $316 \mathrm{~N}$ stainless steel that had been in service for $96,000 \mathrm{~h}$ at $540^{\circ} \mathrm{C}$. Stress-rupture testing was undertaken to examine strength and ductility. In Fig. 2.9a the rupture strength of the type $316 \mathrm{~N}$ stainless steel base metal has been compared to type 316 stainless steel on the basis of the Larson Miller time-temperature parameter. Trends indicate that the type 316N stainless steel provide a strength advantage greater than $25 \%$ above steel not strengthened by nitrogen. Ductility of the type $316 \mathrm{~N}$ stainless steel was excellent, as shown in Fig. $2.9 \mathrm{~b}$. Values for elongation exceeded $20 \%$ and the reduction of area values exceeded $30 \%$. The piping was removed from service because cracks were observed in welds. These were thought to arise from hot cracks produced in the original field welds. Some additional work is being performed to examine the use of the controlled residual element CRE 16-8-2 stainless steel filler metal for joining the type $316 \mathrm{~N}$ stainless steel. Evaluations are now in progress.

\subsection{Testing of Weldments}

The high strength austenitic stainless steels have potential problems with regard to the performance of weldments in long-time, high-temperature service. Alloys that are balanced 
toward ferrite tend to have low creep strength and embrittle due to sigma formation. Base metals and filler metals that are balanced toward austenite have good strength but are susceptible to hot-cracking. ${ }^{8}$ Problems with alloys balanced toward austenite can be mitigated by reducing phosphorous and sulfur in the base metal and selecting the proper filler metal. Typical filler metals that have been examined in connection with the advanced austenitic alloys included Inconel 82॰, 17-14CuMo stainless steel, CRE 16-8-2 stainless steel, and Haynes alloy 5560. Performance of weldments to $10,000 \mathrm{~h}$ was reported previously. ${ }^{6}$ Testing has been continued and times are approaching $20,000 \mathrm{~h}$. The alloy 556 continues to offer the best strength at long times and high temperatures. No ruptures have been produced in this reporting period, so additional information on failure locations is not available.

\subsection{Evaluation of Modified Alloy $800 \mathrm{H}$}

The high-chromium austenitic iron-base alloys are those that contain 20 to $30 \%$ chromium, and 20 to $35 \%$ nickel. Examples are type 310 stainless steel and alloy $800 \mathrm{H}$. There are many modifications to the alloys, and new alloys of particular interest to the advanced austenitic alloy evaluation activity include Sumitomo $\mathrm{HR} 3 \mathrm{C}^{\bullet}$, which is a modified type 310 stainless steel, ${ }^{9}$ and Nippon Steel NF709 , which is a modified $20 \mathrm{Cr}-25 \mathrm{Ni}$ steel. ${ }^{10}$ In addition, modifications of alloy 800 were undertaken by Maziasz, ${ }^{3}$ and this alloy has been produced as plate and tubing. An evaluation of the potential of these alloys for advanced steam service was completed in 1991." Since then, interest in the alloys for combined cycle applications at higher temperatures has developed, and the testing program on the materials has been expanded.

Much of the current research at ORNL has focused on the modified alloy $800 \mathrm{H}$ tubing produced by Babcock \& Wilcox Company. ${ }^{12}$ Material that was initially examined had been cold finished and solution treated at a relatively low temperature (less than $1150^{\circ} \mathrm{C}$ ). A new batch of tubing was received that had been solution treated at $1190^{\circ} \mathrm{C}$ and cold pilgered. Initial results indicated that the new fabrication route produced a material has twice the strength of alloy $800 \mathrm{H}$ at temperatures to $760^{\circ} \mathrm{C}$. Testing times are relatively short, however, and the long time stability of the microstructure is an issue that has yet to be resolved.

Evaluation of weldments in modified alloy $800 \mathrm{H}$ continued. Again, alloy 556 has been used as a filler metal, and welds have been produced at ORNL and at the University of Tennessee. Times for in stress-rupture testing of transverse weldment specimens have exceeded $5,000 \mathrm{~h}$ for temperatures in the range 600 to $700^{\circ} \mathrm{C}$. Include were samples that had 

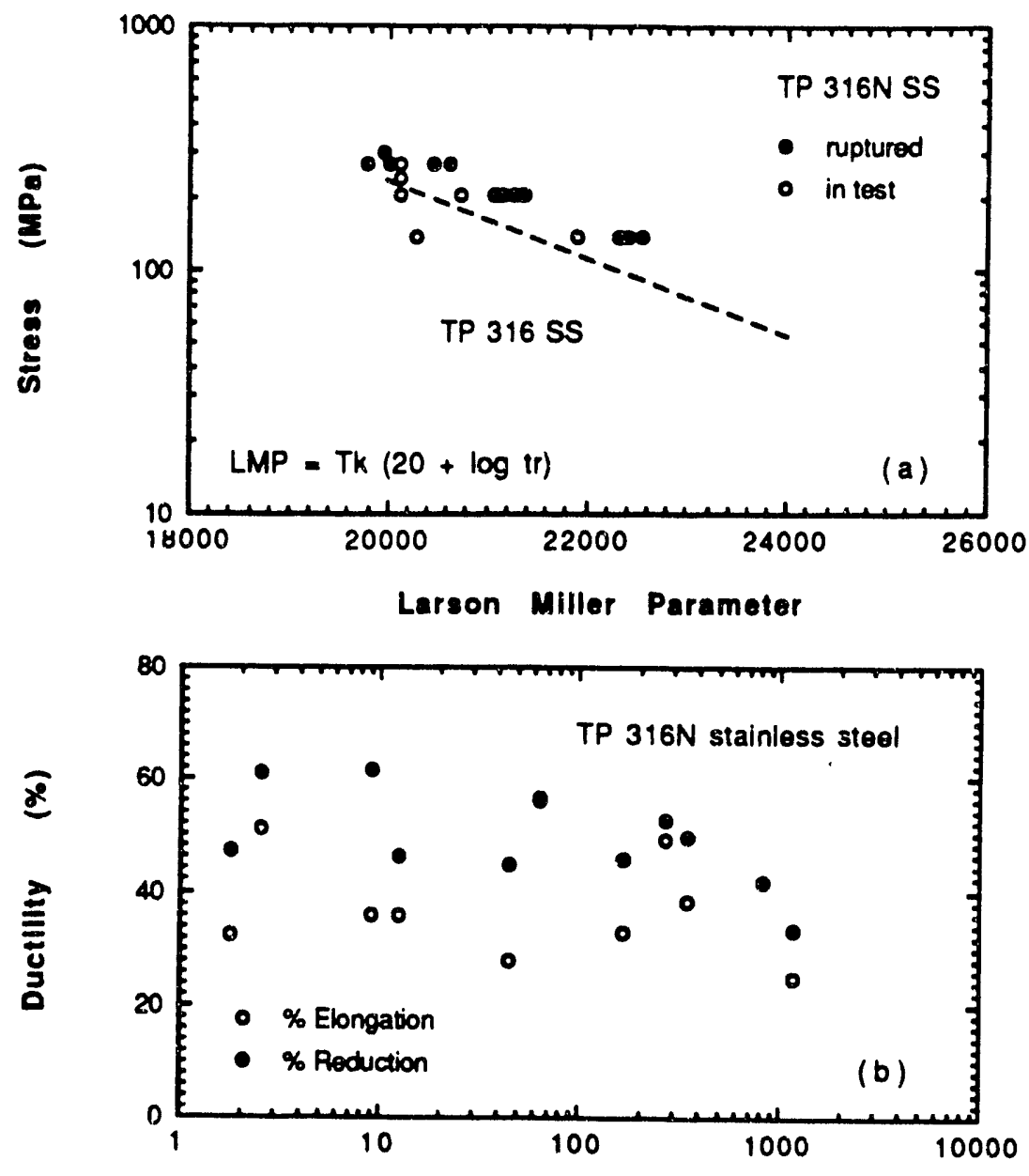

Time (h)

Fig. 2.9. Stress rupture data for type $316 \mathrm{~N}$ stainless steel taken from a steam plant after $96,000 \mathrm{~h}$ at $540^{\circ} \mathrm{C}$ : (a) comparison of the rupture strength with the trend for type 316 stainless steel on the basis of the Larson-Miller time-temperature parameter; (b) ductility versus time of rupture.

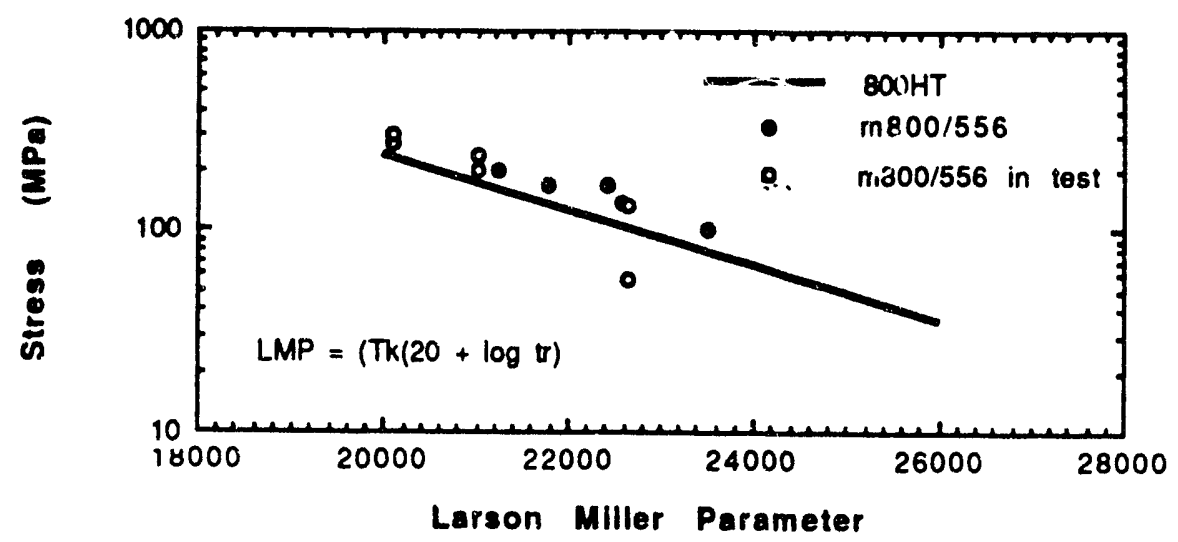

Fig. 2.10. Comparison of the rupture strength of transverse (cross) weldments of modified alloy $800 \mathrm{H}$ with the trend for alloy $800 \mathrm{HT}$ on the basis of the Larson Miller time temperature parameter. 
been solution treated at $1200^{\circ} \mathrm{C}$ and welded either before or after cold working. In Fig. 2.10 the rupture data on transverse (cross) weldment specimens have been compared to alloy $800 \mathrm{HT}$ on the basis of the Larson Miller time-temperature parameter. Trends suggest that the strength of weldments in the modified alloy 800 is approximately $25 \%$ grater than alloy $800 \mathrm{HT}$ base metal. In contrast to the lean stainless steels, which rupture in the alloy 556 filler metal, the modified alloy 800 weldments fail in the base metal of heat affect zone at short times. Long time testing is still in progress.

Several experimental modified alloy $800 \mathrm{H}$ heats were produced to evaluate the influence of minor element additions on oxidation resistance and weldability. A lower propensity for hot cracking was observed for these heats, while cyclic cxidation tests to $1000^{\circ} \mathrm{C}$ indicated that some heats were equivalent to standard alloy $800 \mathrm{H}$.

\subsection{Alloys for Hot-Gas Cleanup Applications}

Hot-gas cleanup systems are being developed for pressurized fluidized bed combustors (PFBC). One cleanup concept involved the use of ceramic barrier filters that operate at temperatures in the range 800 to $900^{\circ} \mathrm{C}{ }^{4}$ Metallic materials will be used to support the filters and fabricate the blowback manifold systems that are required for filter cleaning. Although the gaseous environment is oxidizing, a potential for some sulfidation exists if sulfur-bearing particulates collect on metallic components in the dirty gas side of the cleanup vessel. High oxidation resistance, fabricability, and good thermal fatigue resistance are of primary concern in the selection of the structural components, and several alloys are being investigated to establish the potential for eventual use. Alloys of interest include RA3330, Haynes alloy 556 , Inconel 617 ${ }^{\circ}$ HR $160^{\circ}$, and the nickel-chromium-aluminides IC221 and IC396M. Research is being directed at producing the data needed for high-temperature component design, rather than optimization of chemistry or fabrication processes, and work underway includes creepfatigue, thermal-mechanical fatigue, and the development of parameters needed in design evaluations.

Examination has been completed of RA333 and Haynes alloy 556 for use in the Tidd hot-gas clean vessel, and results have been reported elsewhere. ${ }^{13,14}$ The nickel-chromiumaluminides offer an advantage over these two alloys for service under conditions of low primary stress and high transient loadings because they possess high yield strengths and relatively poor creep strengths. This combination reduces the likelihood of plastic strains during transients and the rapid relaxation of any residual stresses that would produce creep 
damage during steady state operations. Research was undertaken on an electroslag casting of alloy IC396M. Most tensile, creep, and relaxation testing was completed, and a few fatigue tests and creep-fatigue tests have been undertaken on the material.

\subsubsection{Summary}

Long-time testing of HT-UPS austenitic stainless steel continued to indicate excellent strength and ductility in this type of steel.

Stress-rupture testing of transverse (cross) weldments in the HT-UPS steel joined with type 16-8-2 CRE and alloy 556 filler metals has extended to beyond 10,000 h. Both filler metals show good strength and ductility.

Creep-rupture testing of modified alloy $800 \mathrm{H}$ tubing in the cold-pilgered condition indicated excellent strength relative to alloy $800 \mathrm{HT}$.

\subsection{References}

1. P. L Rittenhouse, et al., Assessment of Materials Needs for Advanced Steam Cycle Coal Fired Plants, ORNL-6274, Oak Ridge National Laboratory, Oak Ridge, Tennessee, 1985.

2. S. Kjaer, "Elsam $400 \mathrm{MW}$ Coal-Fired USC-Power Plant Investigation," paper presented at the Third International Conference on Improved Coal-Fired Power Plants (ICPP), San Francisco, California, April 2-4, 1991.

3. P. E. Duffy and C. Knox, "Topping Systems for Repowering Coal Fueled Plants," paper presented at the Third International Conference on Improved Coal-Fired Power Plants (ICPP), San Francisco, California, April 2-4, 1991.

4. T. E. Lippert, et al., Performance Evaluation of a Ceramic Cross-Flow Filter on a BenchScale Coal Gasifier, DOE/MC/21338-2749, Vol. 1 and 2, U.S. Department of Energy, Morgantown Energy Technology Center, Morgantown, West Virginia (September 1989).

5. R. W. Swindeman, et al., Alloy Design Criteria and Evaluation Methods for Advanced Austenitic Alloys in Steam Service, ORNL-6274, Oak Ridge National Laboratory, Oak Ridge, Tennessee, May 1986.

6. R. W. Swindeman, et al., Evaluation of Advanced Austenitic Alloys Relative to Alloy Design Criteria for Steam Service- Part 1- Lean Stainless Steels, ORNL-6629, Oak Ridge National Laboratory, Oak Ridge, Tennessee, May 1990.

7. P. J. Maziasz, "Developing an Austenitic Stainless Steel for Improved Performance in Fossil Power Facilities," J. Met. 41, 14-20 (1989).

8. C. D. Lundin, et al., The Hot Ductility and Hot Cracking Behavior of Modified 316 Stainless Steels Designed for High Temperature Service, University of Tennessee Report No. ORNL/Sub/88-07685/01, Knoxville, Tennessee, 1989. 
9. Y. Sawaragi, H. Teranishi, and K. Yoshikawa, "The Development of Newly Steel with High Elevated Temperature Strength and High Corrosion Resistance for Boiler," pp. 238-44 in Proceedings, International Conference on Creep, Japan Society of Mechanical Engineers, Tokyo, Japan, 1988.

10. T. Takahashi, et al., "Development of a High Strength $25 \mathrm{Ni}-20 \mathrm{Cr}$ Steel for Tubes in Ultra Supercritical Power Boilers," paper 41-1 in Second International Conference on Improved Coal Fired Power Plants, EPRI publication GS-6422, 1989.

11. R. W. Swindeman, et al., Evaluation of Advanced Austenitic Alloys Relative to Alloy Design Criteria for Steam Service-Part 2 - 20 to 30\% Chromium Alloys, ORNL-6629, Oak Ridge National Laboratory, Oak Ridge, Tennessee, May 1990.

12. M. Topolski, Evaluation of the Fabricability of Advanced Austenitic Tubing, Final Report CRD \# 1207, RDD:91:4500-01-01:01, Babcock \& Wilcox Alliance Research Center, Alliance, Ohio, March 1991.

27 DEVELOPMENT OF IRON ALUMINIDES - C. G. McKamey, V. K. Sikka, T. Zacharia, and D. J. Alexander

Iron aluminides based on $\mathrm{Fe}_{3} \mathrm{Al}$ have excellent oxidation and corrosion resistance. ${ }^{1}$ However, until recently their potential use as structural material has been hindered by low room temperature ductility $(<5 \%)$ and a drop in strength above $600^{\circ} \mathrm{C}^{2}$ Recent studies indicate that the poor ambient-temperature ductility observed in many aluminides is often caused by dynamic hydrogen embrittlement resulting from the dissociation of water molecules in the environment by aluminum atoms on the surface of the alloy. ${ }^{3-6}$ This environmental embrittlement can be minimized through modification of alloy chemistry, microstructure, and surface condition. ${ }^{5-8}$ Development efforts at this laboratory have indicated that by controlling alloy chemistry and thermomechanical processing, $\mathrm{Fe}_{3} \mathrm{Al}$-based alloys can achieve ambient temperature tensile ductilities of $10-20 \%$ and tensile yield strengths of as high as $500 \mathrm{MPa}$. ${ }^{7,9}$

$\mathrm{Fe}_{3} \mathrm{Al}$ has been known for some time to have very poor creep resistance. ${ }^{2}$ Preliminary studies of $\mathrm{Fe}_{3} \mathrm{Al}$-based ternary alloys have shown that additions of molybdenum or niobium result in improved creep rupture properties. At $593^{\circ} \mathrm{C}\left(1100^{\circ} \mathrm{F}\right)$ and $207 \mathrm{MPa}(30 \mathrm{ksi})$, the binary lasted only $2-5 \mathrm{~h}$, while the niobium-containing ternary alloy lasted over $300 \mathrm{~h} .{ }^{10}$ Although niobium and, to a lesser extent, molybdenum greatly improve the creep rupture resistance as ternary additives, ${ }^{10,11}$ they do not necessarily provide room temperature ductility. With additions of other elements whose primary effect is to produce room-temperature ductility, syruergistic effects become important. One purpose of the present phase of our alloy development program is to study such synergistic effects and separate the positive from 
negative synergisms, so that $\mathrm{Fe}_{3} \mathrm{Al}$-based alloys can be produced with improved creep rupture resistance to temperatures of $650-700^{\circ} \mathrm{C}$, adequate room temperature tensile ductility $(>10 \%)$, and still be weldable, fabricable, and maintain their excellent corrosion resistance.

Welding is a major area of concern for realizing the potential benefits of the unique properties of iron aluminides. The welding processes used must be capable of producing high quality weldments under field and shop conditions which are free of defects and have good mechanical properties in comparison to the base metal. Initial work on the weldability of intermetallic alloys has identified some potential problems associated with these alloys. ${ }^{12-14}$ These include a propensity for hot-cracking, a propensity for cold-cracking, and a possible degradation of the mechanical properties of the weldment in comparison to the base metal. The preliminary results of weldability studies of FA-129 indicate that this alloy may be welded by optimizing the welding process and parameters. However, those studies have also shown that iron aluminides are very sensitive to minor changes in composition of the base metal. ${ }^{15}$

Three categories of $\mathrm{Fe}_{3} \mathrm{Al}$ alloys are under investigation at Oak Ridge National Laboratory (ORNL). The first composition has been optimized for sulfidation resistance and is designated as FAS. The second has been designed for maximum room temperature tensile ductility and is designated as FAL. The third is being designed for a combination of tensile ductility and high-temperature strength and is designated as FA-129. Its final designation will be FAH. Nominal compositions of these three alloys are given in Table 2.6. Initially, mechanical property data was generated on experimental-size heats ranging from 0.5 to $7 \mathrm{~kg}^{7,16,17}$ The commercial melting, fabrication, and properties of 80 - and $100-\mathrm{kg}$ heats were described during the last reporting period. ${ }^{18}$

This report presents the current status of microalloying studies to produce an alloy with improved creep resistance and weldability, analytical electron microscopy to identify precipicates and correlate precipitate compositions with properties, weldability of recentlyproduced microalloyed alloys, and weldability of thick sections (0.5 in.) of FA-129 alloy. The commercial melting and properties of 2000 - and $3000-\mathrm{kg}$ heats of alloy FA-129 are also described.

\subsection{Alloy Development for Improved Creep Resistance}

In terms of alloy development, this reporting period hasw been devoted to producing compositions which have an acceptable combination of several properties including tensile strength and ductility (both at room temperature and $600^{\circ} \mathrm{C}$ ), creep-rupture resistance, and 
weldability. Alloy FA-129, which is currently being scaled-up to commercial-size castings for extensive study (see below), has good tensile properties at tempreatures to approximately $650^{\circ} \mathrm{C}$, with a room temperature ductility of $15-20 \%$. It also has been shown that it can be welded using controlled pre- and post-weld heat treatments. ${ }^{15}$ However, it has inadequate creep-rupture resistance $\left(20-30 \mathrm{~h}\right.$ life at $593^{\circ} \mathrm{C}$ and $\left.207 \mathrm{MPa}\right) .^{19}$ On the other hand, alloy FA-97 has very good creep-rupture resistance $\left(400-500 \mathrm{~h}\right.$ life at $593^{\circ} \mathrm{C}$ and $\left.207 \mathrm{MPa}\right),{ }^{19}$ but poor room temperature tensile ductility and poor weldability (see below). Several alloys with compositions which are compromises between these two alloys were therefore produced and tested during this reporting period in an effort to produce one alloy with an acceptable combination of properties.

The alloys were prepared by arc-melting and drop casting into chilled copper molds. Hot rolling to $0.76-\mathrm{mm}$-thick sheet was accomplished at either $1000-600^{\circ} \mathrm{C}$ or $1000-850^{\circ} \mathrm{C}$, depending on composition. Flat tensile specimens $(0.76 \times 3.18 \times 12.7 \mathrm{~mm})$ were mechanically punched from the hot rolled sheet and were used for both tensile and creep-rupture tests. All heat treatments were performed in air, with quenching by either air or oil. For comparison between alloy compositions, tensile tests were performed at room temperature (RT) in air at a strain rate of $3.3 \times 10^{-3} / \mathrm{s}$ and creep rupture tests were performed in air at $593^{\circ} \mathrm{C}$ and $207 \mathrm{MPa}$.

Table 2.6. Compositions of Ductile $\mathrm{Fe}_{3} \mathrm{Al}$-Based Alloys

\begin{tabular}{cccc}
\hline & \multicolumn{3}{c}{ Alloy $(w t \%)$} \\
Element & FAS $^{a}$ & FAL $^{b}$ & FA-129 $^{c}$ \\
\hline $\mathrm{Al}$ & 15.9 & 15.9 & 15.9 \\
$\mathrm{Cr}$ & 2.2 & 5.5 & 5.5 \\
$\mathrm{~B}$ & 0.01 & 0.01 & -- \\
$\mathrm{Zr}$ & -- & 0.15 & - \\
$\mathrm{Nb}$ & -- & - & 1.0 \\
$\mathrm{C}$ & -- & - & 0.05 \\
$\mathrm{Fe}$ & Balance & Balance & Balance \\
\hline
\end{tabular}

"Maximum sulfidation resistance.

${ }^{b}$ Maximum room-temperature tensile ductility. 'High-temperature tensile strength with good roomtemperature ductility. 
Table 2.7 shows the compositions of alloys FA-97, -129 and several alloys produced during this reporting period. Table 2.8 compares their tensile and creep properties. Our studies in the past have suggested that a certain ratio of molybdenum, niobium, and zirconium is needed for creep resistance, but too much of any one can harden the alloy and lower the room temperature tensile ductility. a Jso, while carbon is detrimental to creep resistance, a certain level of carbon is desirable to promote weldability. ${ }^{20}$ On the other hand, too much zirconium or boron results in reduced weldability. The properties of the new alloys (Table 2.8) indicate that (1) levels of $0.03-0.05$ at.\% $\mathrm{C}$ are acceptable for both creep resistance and weldability, (2) boron is not necessary for creep resistance and may not be needed for ductility, but in any case, to promote weldability, should be kept at $0.005 \%$ or less, (3) for weldability, the zirconium level should be kept below 0.05 at.\%, and (4) the molybdenum level needs to be near $0.4 \%$ for creep resistance. It is anticipated that, with optimization of fabrication techniques, alloys FA-169 and -170 will exhibit room temperature tensile ductilities of approximately $10 \%$. These studies are promising and indicate that development of an alloy that will have a good combination of tensile and creep properties and weldability, as well as adequate corrosion resistance, may be possible in the near future.

Table 2.7. Compositions of Iron Aluminides Under Study

\begin{tabular}{ccccccccc}
\hline & \multicolumn{7}{c}{ Composition (at.\%) } \\
Designation & $\mathrm{Al}$ & $\mathrm{Cr}$ & $\mathrm{Nb}$ & $\mathrm{Mo}$ & $\mathrm{Zr}$ & $\mathrm{C}$ & $\mathrm{B}$ & $\mathrm{Fe}$ \\
\hline FA-97 & 28 & 2.0 & 0.5 & 2.0 & 0.1 & & 0.2 & Bal. \\
FA-129 & 28 & 5.0 & 0.5 & & & 0.2 & & Bal. \\
FA-167 & 28 & 5.0 & 0.5 & 0.25 & 0.025 & 0.1 & 0.005 & Bal. \\
FA-168 & 28 & 5.0 & 0.5 & 0.8 & 0.05 & 0.03 & 0.005 & Bal. \\
FA-169 & 28 & 5.0 & 0.5 & 0.25 & 0.025 & 0.05 & & Bal. \\
FA-170 & 28 & 5.0 & 0.5 & 0.4 & 0.025 & 0.05 & & Bal. \\
\hline
\end{tabular}

\subsection{Creep Mechanisms in Fe, Al-Based Alloys}

Along with efforts to improve creep resistance in $\mathrm{Fe}_{3} \mathrm{Al}$-based alloys through alloying, an effort has been underway to identify creep mechanisms in binary $\mathrm{Fe}_{3} \mathrm{Al}$ and to determine how creep mechanisms are affected by alloying additions. Details of those studies can be found in the recent literature. ${ }^{19,21,2}$ During this reporting period analytical electron microscopy (AEM) techniques [including $x$-ray energy dispersive spectroscopy (XEDS), selected-area diffraction $(\mathrm{SAD})$, and convergent-beam electron diffraction (CBED)] were used to identify precipitates 
Table 2.8. Properties of $\mathrm{Fe}_{3} \mathrm{Al}$ Alloys

\begin{tabular}{lccccccc}
\hline & \multicolumn{5}{c}{ RT Tensile ${ }^{\mathrm{a}, \mathrm{b}}$} & \multicolumn{5}{c}{ Creep rupture } \\
\multicolumn{1}{c}{ Alloy } & $\begin{array}{c}\text { Yield } \\
(\mathrm{MPa})\end{array}$ & $\begin{array}{c}\text { Ultimate } \\
(\mathrm{MPa})\end{array}$ & $\begin{array}{c}\text { Elong. } \\
(\%)\end{array}$ & $\begin{array}{c}\text { Life } \\
(\mathrm{h})\end{array}$ & $\begin{array}{c}\text { Elong. } \\
(\%)\end{array}$ & $\begin{array}{c}\text { MCR } \\
(\% / \mathrm{h})\end{array}$ & Weldable? \\
\hline FA-129 & 384 & 930 & 16.9 & $22^{\mathrm{c}}$ & 75 & 0.95 & $\mathrm{Y}$ \\
FA-97 & $>690$ & & $<5.0$ & $463^{\mathrm{c}}$ & 47 & 0.04 & $\mathrm{~N}$ \\
& & & & & & & \\
FA-167 & $505(509)$ & $723(822)$ & $5.4(3.6)$ & $84^{\mathrm{a}}$ & 47 & 0.3 & $\mathrm{Y}$ \\
FA-168 & $635(686)$ & $744(773)$ & $2.5(4.9)$ & $391^{\mathrm{a}}$ & 65 & 0.06 & $\mathrm{~N}$ \\
FA-169 & $(502)$ & $(803)$ & $(8.7)$ & $40^{\mathrm{d}, \mathrm{a}}$ & 36 & 0.6 & $\mathrm{Y}$ \\
FA-170 & $(474)$ & $(680)$ & $(5.5)$ & $281^{\mathrm{d}, \mathrm{a}}$ & 32 & 0.04 & $\mathrm{Y}$ \\
\hline
\end{tabular}

${ }^{2}$ Heat treated $1 \mathrm{~h} / 750^{\circ} \mathrm{C}$ air cooled.

bValues in parentheses were produced using grips designed to hold the specimen under the shoulders, not in the pinholes.

${ }^{\circ}$ Heat treated $1 \mathrm{~h} / 850^{\circ} \mathrm{C}+3-7 \mathrm{~d} / 500^{\circ} \mathrm{C}$; tested at $593^{\circ} \mathrm{C}$ and $207 \mathrm{MPa}$.

${ }^{\mathrm{d}} \mathrm{Hot}$ rolled at $850^{\circ} \mathrm{C}$; starting microstructure consisted of large recrystallized grains.

in $\mathrm{Fe}_{3} \mathrm{Al}$ alloyed with $2 \%$ Mo or $1 \% \mathrm{Nb}$. $\mathrm{AEM}$ analysis of the precipitates in $\mathrm{Fe}_{3} \mathrm{Al}+2 \% \mathrm{Mo}$ extracted on a carbon replica film showed that they were Mo-rich ( $>95$ at.\% Mo) and had the hexagonal crystal structure characteristic of $\mathrm{Mo}_{2} \mathrm{C}$ phase (Fig. 2.11). ${ }^{21,22}$ The niobiumcontaining ternary alloy contained coarse and fine precipitates in the matrix and at grain boundaries which were identified as $\mathrm{Nb}$ - and/or $\mathrm{Zr}$-rich carbides. ${ }^{21.22}$ The presence of zirconium in this alloy was not intentional, and was assumed to have been introduced during melting and casting. Many small (50-90 nm in size) $\mathrm{Zr}$-rich $\mathrm{MC}$ particles ( $>70$ at.\% $\mathrm{Zr}$ ) were dispersed uniformly throughout the matrix and were associated with dislocations (Fig. 2.12). Most likely the small matrix and grain boundary precipitates contributed to the low creep rate and high creep-rupture resistance observed in this specimen $\left(300 \mathrm{~h}\right.$ life at $650^{\circ} \mathrm{C}$ and $138 \mathrm{MPa}$ compared to $0.6 \mathrm{~h}$ for $\mathrm{Fe}_{3} \mathrm{Al}$ and $50 \mathrm{~h}$ for $\mathrm{Fe}_{3} \mathrm{Al}+2 \mathrm{Mo}$ ).

\subsection{Weldability of Alloy FA-129}

Initial work on the weldability of FA-129 based iron aluminides have shown that these alloys may be welded by controlling the welding process and parameters. ${ }^{15}$ Crack-free welds were produced by preheating the base metal to $200^{\circ} \mathrm{C}$ and postweld heat treating at $700^{\circ} \mathrm{C}$ for one hour. Pre- and postweld-heat treating, in general, lowers the amount of thermal stresses. In addition the slower cooling rate may provide an opportunity for any hydrogen that may be present in the weld metal to diffuse out without causing cracking. Following this, a systematic 


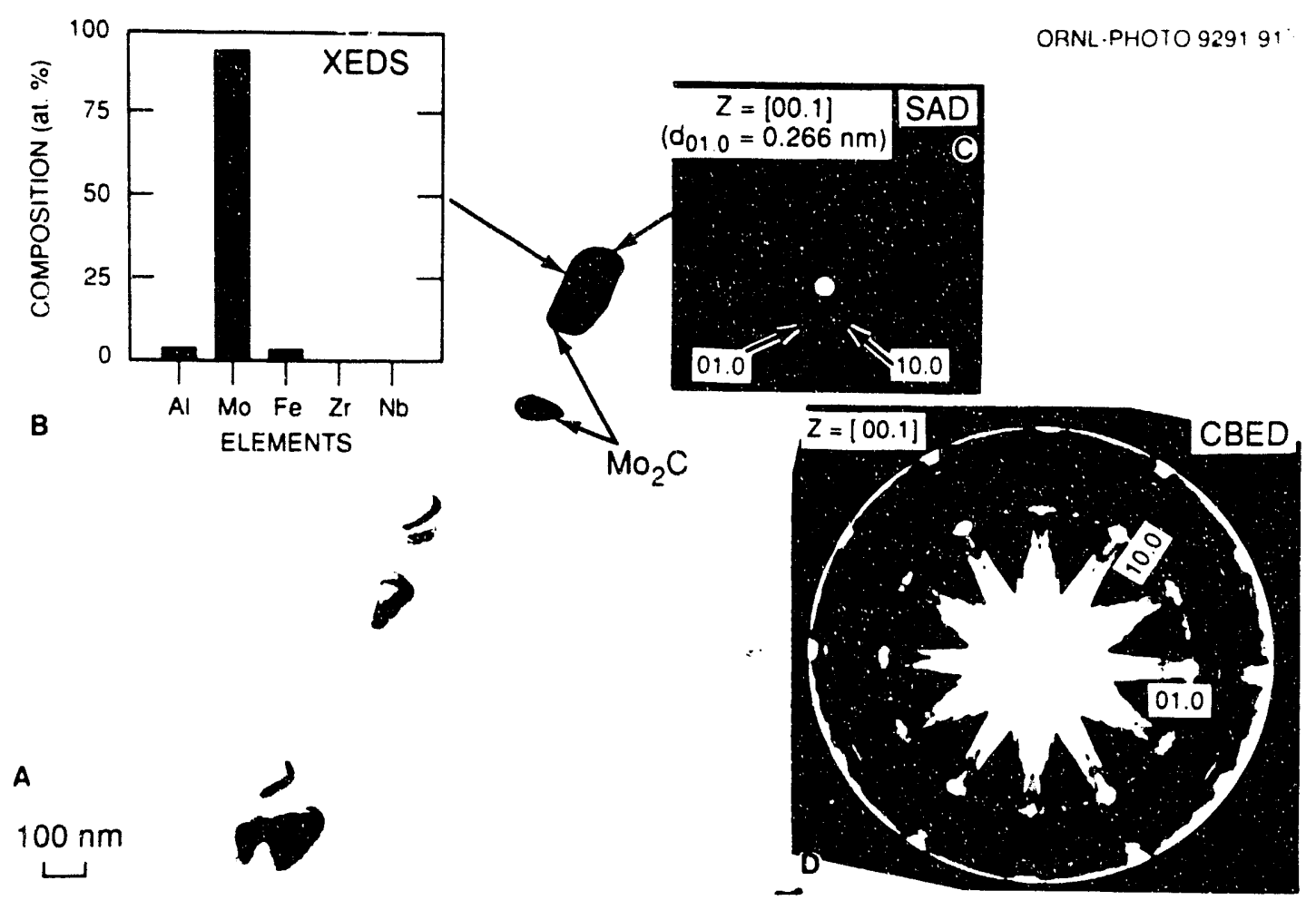

Fig. 2.11. AEM (a) of grain boundary precipitates in $\mathrm{Fe}_{3} \mathrm{Al}+2 \mathrm{Mo}$ alloy creep tested at $650^{\circ} \mathrm{C}$ and $276 \mathrm{MPa}$. XEDS (b), SAD (c), and CBED (d) shows the precipitates are the hexagonal $\mathrm{Mo}_{2} \mathrm{C}$ phase.

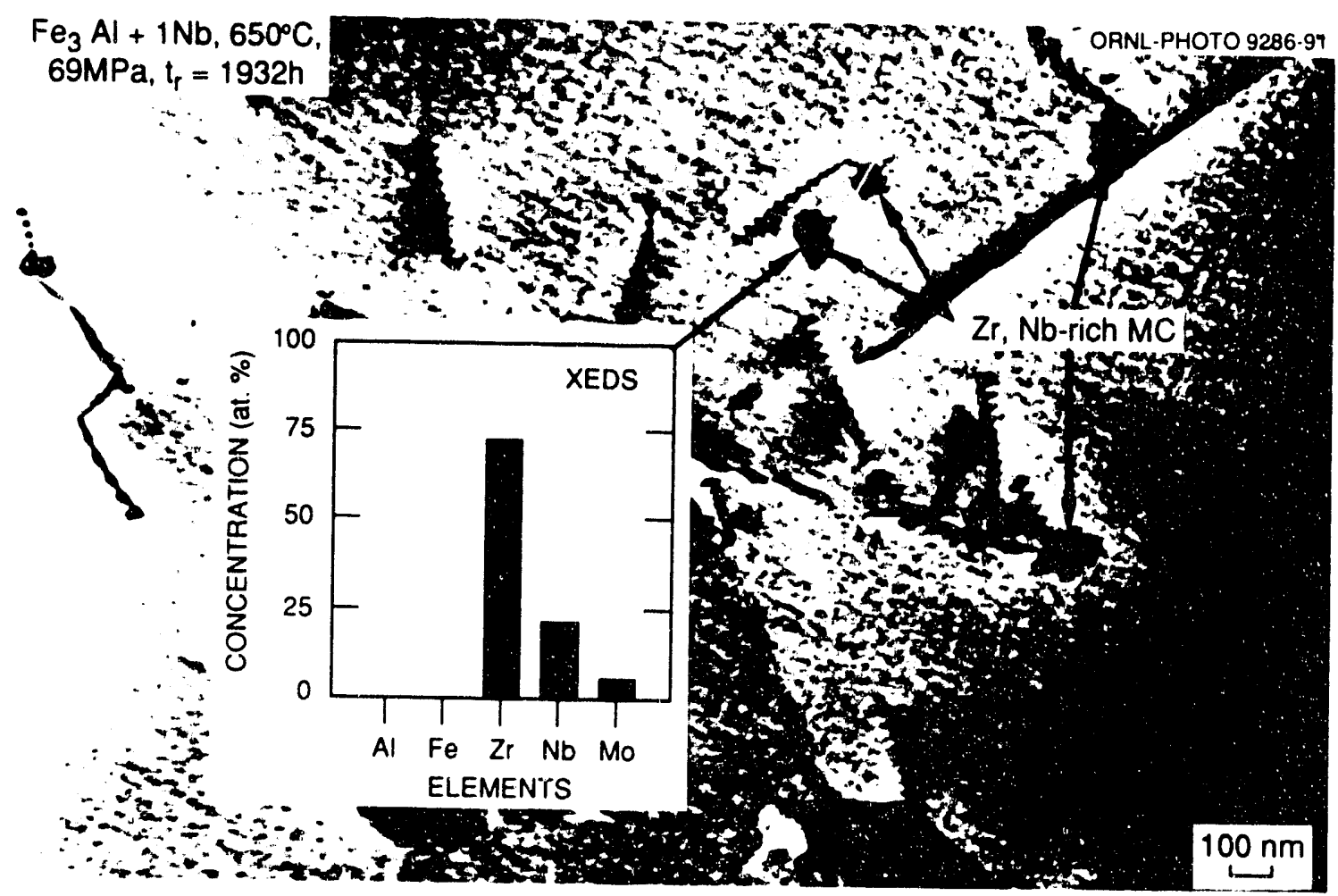

Fig. 2.12. TEM microstructure of a $\mathrm{Fe}_{3} \mathrm{Al}+1 \mathrm{Nb}$ alloy creep tested at $650^{\circ} \mathrm{C}$ and $69 \mathrm{MPa}$ showing pinning of dislocations by $\mathrm{Zr}$-rich MC precipitates. XEDS shows presence of both $\mathrm{Zr}$ and $\mathrm{Nb}$. 
study was undertaken to evaluate the optimum pre- and postweld-heat treatment conditions. The results of the study indicate that successful welds can be made on laboratory specimens with a minimum preheat of $100^{\circ} \mathrm{C}$ and a postweld heat treatment of $400^{\circ} \mathrm{C}$ for one hour.

For the first time, welds have been made on $12.6 \mathrm{~mm}(0.5$ in.) thick FA-129 material. The scaled-up alloy was obtained in the form of $6.3 \mathrm{~mm}(0.25 \mathrm{in}$.) and $12.6 \mathrm{~mm}(0.5 \mathrm{in}$.) plates. Welds were made on the plates using matching FA-129 filler metal deposited in a $90^{\circ}$ included-angle $\mathrm{V}$-groove with a $1.6 \mathrm{~mm}$ root opening. The welds were made using alternating current with argon shielding and backing gas. The filler wire was heat treated for $2 \mathrm{~h}$ at $300^{\circ} \mathrm{C}$ and the specimens were degreased and cleaned thoroughly prior to welding. The techniques developed for the $6.3 \mathrm{~mm}(0.25 \mathrm{in}$.) plates, including pre- and postweld-heat treatments, were successfully used to produce crack free welds in the thicker sections. Figure 2.13 shows the transverse section of the weld indicating very coarse grain structure in the fusion zone that may have an impact on its toughness.

ORNL Photo 91-1139-1

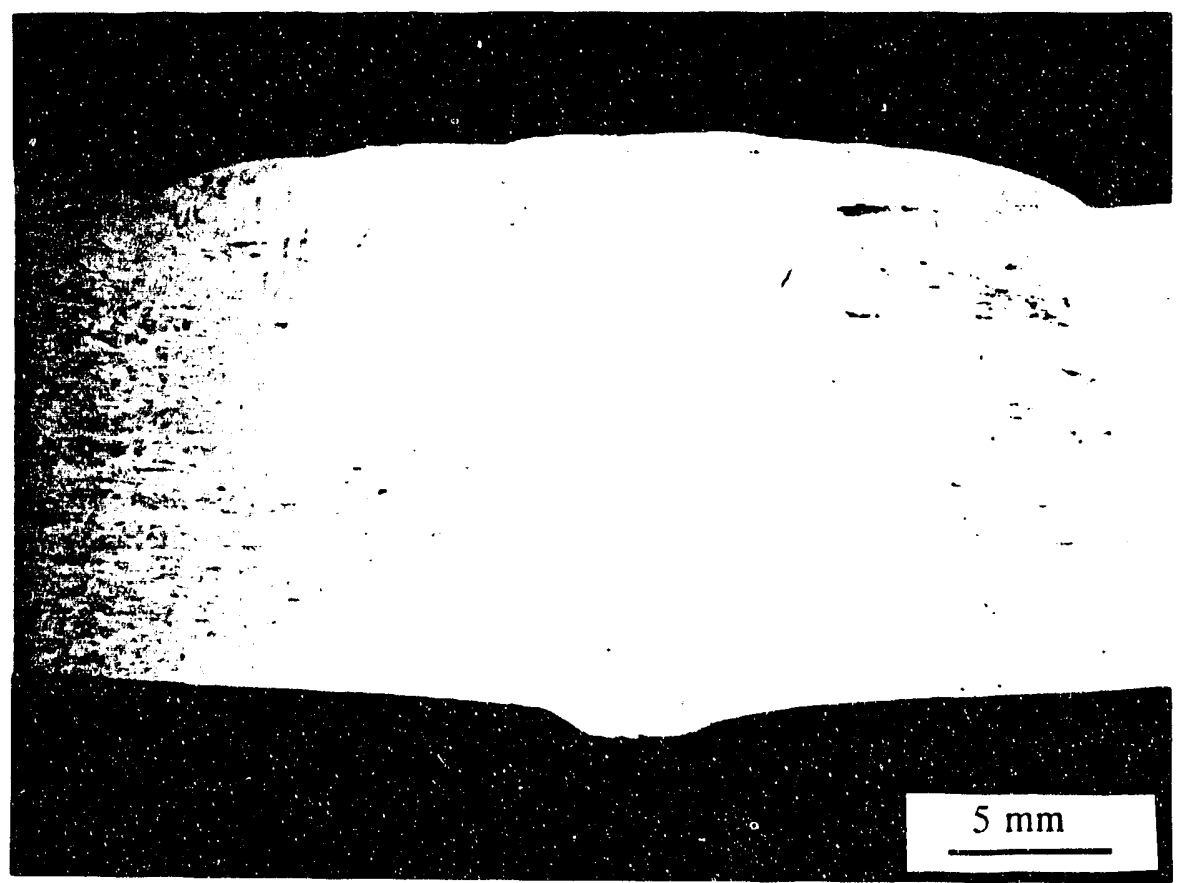

Fig. 2.13. Transverse section of $12.7-\mathrm{mm}(0.5 \mathrm{in}$.) thick FA-129 plate showing coarse columnar structure in weld fusion zone. 


\subsubsection{Weldability of Micro-Alloyed Iron Aluminides}

Preliminary screening tests were performed on several new alloys. The compositions of these alloys are listed in Table 2.7. These alloys were tested for hot-crack susceptibility using the Sigmajig test. The test has been used in the past to identify crack susceptibility of several iron-aluminide alloys including FA-129. The test uses a preapplied transverse stress during autogenous GTA welding of a $50 \mathrm{~mm} \times 50 \mathrm{~mm}$ sheet specimen. The applied stress is sequentially increased until the specimen cracks. This test ranks materials based on the threshold stress above which cracking in the fission zone occurs. The welds were characterized using optical microscopy of specimens etcheri with a solution containing $40 \mathrm{ml} \mathrm{HNO}_{3}, 60 \mathrm{ml}$ $\mathrm{CH}_{3} \mathrm{COOH}$, and $20 \mathrm{ml} \mathrm{HCl}$.

The preliminary results on the Sigmajig threshold cracking stress for the various alloys are presented in Table 2.9. Based on these results, several of these alloys indicate a potential for good weldability. The results clearly show that the weldability of iron aluminides are sensitive to changes in composition. Alloy FA-97 containing molybdenum and boron, which has excellent creep properties, showed very poor weldability. Although boron has been found to improve fabricability and grain boundary strength of iron aluminides, the results of the welding study suggest that boron is deleterious to weldability. Among alloys FA-167 to -170 , all except alloy FA-168 exhibited promise of good weldability, the main difference between the alloys being the higher molybdenum and zirconium content in FA-168. Even though hotcracking may not be a problem for these alloys, cold cracking remains a potential problem. Figure 2.14 shows transverse cold cracks in an alloy FA-167 weldment that developed several days after welding. However, it is expected that a combination of pre- and postweld heat treatments can be used to prevent cold cracking in these alloys.

Table 2.9. Sigmajig Threshold Cracking Stress

\begin{tabular}{cc}
\hline Alloy & $\begin{array}{c}\text { Stress to cause hot-cracking } \\
{[\mathrm{MPa}(\mathrm{ksi})]}\end{array}$ \\
\hline FA-97 $^{\mathrm{a}}$ & $<<138(20)$ \\
FA-129 $^{\mathrm{b}}$ & $=172(25)$ \\
FA-167 $^{\mathrm{b}}$ & $=138(20)$ \\
FA-168 $^{\mathrm{b}}$ & $<<138(20)$ \\
FA-169 $^{\mathrm{a}}$ & $<103(15)$ \\
FA-170 & $>>103(15),<138(20)$ \\
\hline
\end{tabular}

${ }^{2}$ Final processing done at $850^{\circ} \mathrm{C}$.

b Final processing done at $600^{\circ} \mathrm{C}$. 
ORNL Photo 91-0757-2

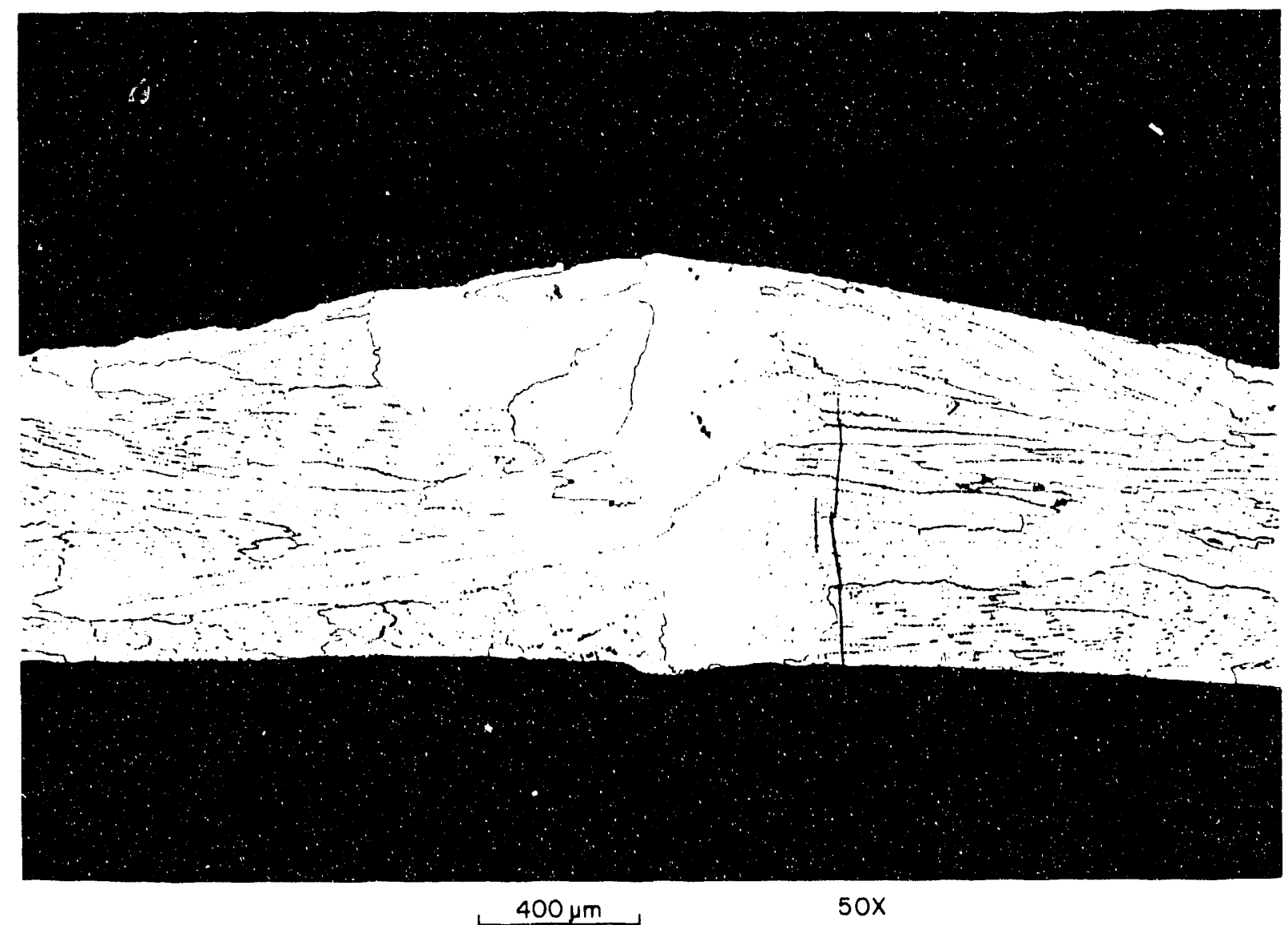

Fig. 2.14. Transverse section of FA-167 weldment showing delayed cold-cracking.

\subsection{Preparation and Fabrication of Commercial-Size Ingots of $\mathrm{Fe}_{3} \mathrm{Al}$-Based Alloys}

The commercial melting of 2000 - and $3000-\mathrm{kg}$ heats was limited to alloy FA-129 only. The scale-up effort is described below.

\subsubsection{Melting}

The scaleup of two heats of FA-129 alloy was conducted at Precision Rolled Products (PRP), Reno, Nevada. The first heat weighing $2000-\mathrm{kg}$ was prepared by vacuum-induction melting (VIM) of the raw materials, was cast into a 330-mm-diam. round electrode, and subsequently electroslag remelted (ESR) into a 406-mm-diam. ingot. The ingot, shown in Fig. 2.15, was slow cooled after removing from the mold and stress relieved at $750^{\circ} \mathrm{C}$ for $8 \mathrm{~h}$. The ingot's surface finish was similar to that observed for most commercial iron- and nickelbase alloys. The surface finish was such that the ingot can be processed without the need for any surface treatment. 
The second heat weighing $3000 \mathrm{~kg}$ was also processed by VIM. However, this heat was cast into a rectangular slab mold of 203 by $965 \mathrm{~mm}$. The slab was removed from the mold, slow cooled, and stress relieved at $750^{\circ} \mathrm{C}$ for $8 \mathrm{~h}$. The slab, shown in Fig. 2.16, will be processed in the as-cast condition. Compared to the ESR ingot, the surface quality of the VIM slab was not as good.

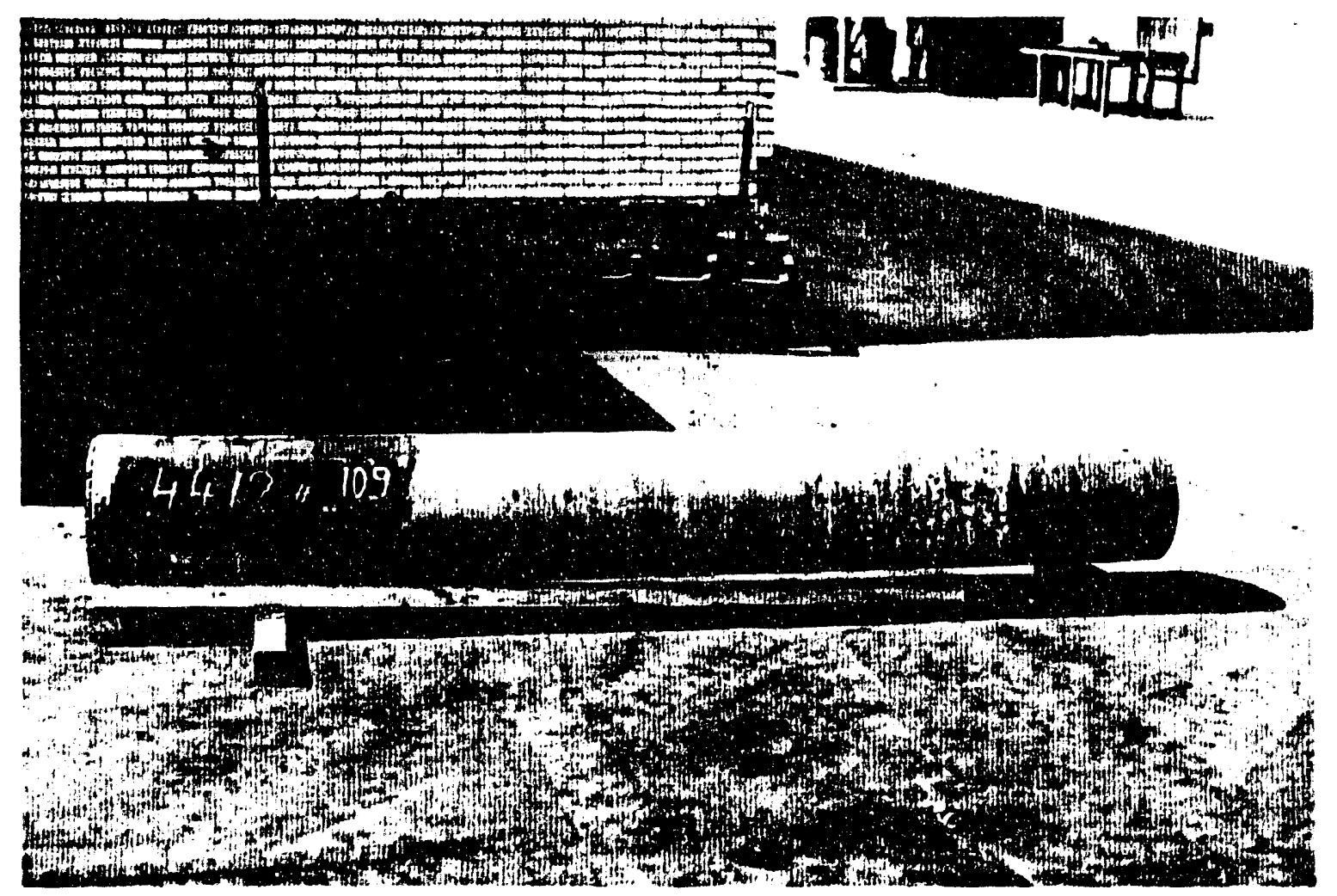

Fig. 2.15. A 406-mm-diam. ingot of alloy FA-129. The alloy was prepared by VIM and ESR at Precision Rolled Products.

Chemical analysis of the large ingots are compared with the target composition in Table 2.10. Note that the compositions of the large ingots are in good agreement with the target composition. PRP indicated that the melting of iron aluminide was no different than many commercial alloys, and that they would produce the alloy if customer requests were received.

\subsubsection{Cutting}

Because of its size, the VIM slab ingot has not been sectioned. However, prior to processing, the entire ESR ingot was sectioned to study its macrostructure and processing 
response. Because of very low ductility in the as-cast condition, ORNL recommended that the ingot be cut by using a slow-speed band saw rather than a high-speed abrasive wheel, a common industry practice. PRP subcontracted the band-saw cutting to another vendor who found it to be extremely difficult to cut. In spite of the slow-cutting response, two slices were sectioned from near the top of the 406-mm-diam. ESR ingot. The sectioned pieces showed evidence of cracks near the center of both slices. The cracking can be either from the solidification process or from the cutting process. Subsequent crack-free cutting of the slices at ORNL suggests that the cracks may be related to the solidification process. The macroand microstructures of the ingot section are shown in Fig. 2.17. The macrostructure is very typical of that observed for the commercial alloys, and the microstructure is very similar to that observed for 102-mm-diam. ingots of the same alloy (FA-129). ${ }^{16}$

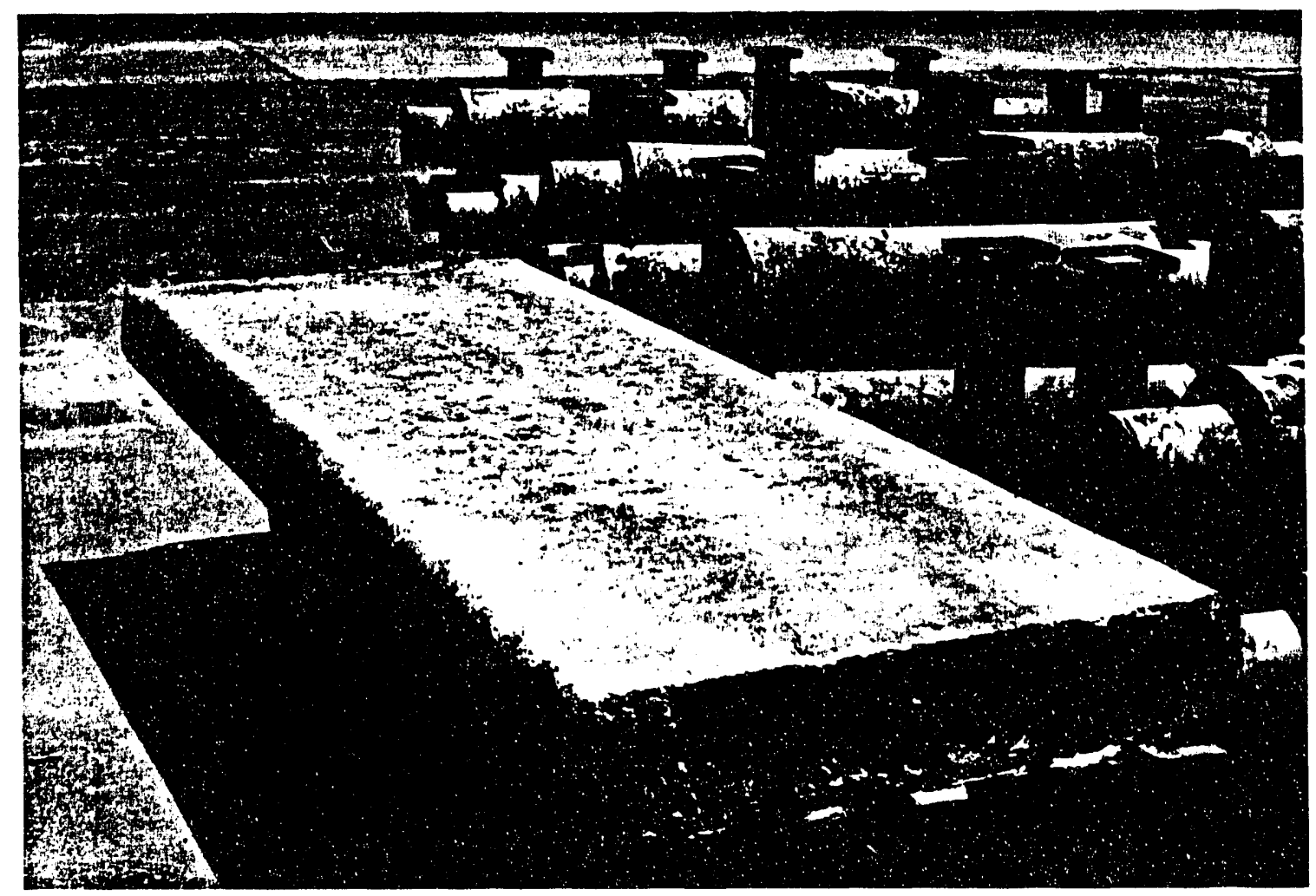

Fig. 2.16. A $203-\mathrm{mm}$ by $965-\mathrm{mm}$ slab of alloy FA-129 prepared by VIM at Precision Rolled Products. Note that, as opposed to the round ingot, this ingot was not electroslag remelted.

\subsubsection{Processing}

A 28-inm-thick piece from the slice representing the top of the 406-mm-diam. ESR ingot was processed into $0.76-\mathrm{mm}$-thick sheet. The processing steps, temperatures, and percent 
reductions are shown schematically in Fig. 2.18. The forging steps were at $1000^{\circ} \mathrm{C}$, followed by rolling steps at 800 and $650^{\circ} \mathrm{C}$, respectively. No problems were encountered in the preparation of the sheet. The processing steps used for the section from the 406-mm-diam. ingot are the same as used previously for 102 -mm-diam. ingots. ${ }^{16}$

Table 2.10. Composition of 406-mm-diam. ESR Ingot of FA-129

\begin{tabular}{cccc}
\hline & \multicolumn{3}{c}{ Composition (wt \%) } \\
\cline { 3 - 4 } Element & Target & \multicolumn{2}{c}{ Check analysis $^{\mathbf{2}}$} \\
\cline { 3 - 4 } \cline { 3 - 4 } composition & Sample 1 & Sample 2 \\
\hline $\mathrm{Al}$ & 15.9 & 16.07 & 15.83 \\
$\mathrm{Cr}$ & 5.5 & 5.87 & 5.98 \\
$\mathrm{Nb}$ & 1.0 & 0.95 & 1.09 \\
$\mathrm{C}$ & 0.05 & 0.01 & 0.04 \\
$\mathrm{Fe}$ & 77.55 & 76.47 & 76.50 \\
$\mathrm{~S}$ & -- & 0.005 & 0.010 \\
$\mathrm{P}$ & -- & 0.034 & 0.034 \\
$\mathrm{Ni}$ & -- & 0.06 & 0.05 \\
$\mathrm{Mo}$ & -- & 0.04 & 0.04 \\
$\mathrm{Mn}$ & -- & 0.31 & 0.23 \\
$\mathrm{Si}$ & -- & 0.09 & 0.08 \\
$\mathrm{~V}$ & -- & 0.01 & 0.01 \\
$\mathrm{Co}$ & -- & 0.02 & 0.03 \\
$\mathrm{Cu}$ & -- & $<0.01$ & $<0.01$ \\
W & -- & 0.05 & 0.07 \\
$\mathrm{~B}$ & -- & 0.002 & 0.002 \\
\hline
\end{tabular}

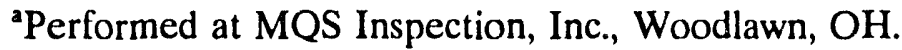

\subsubsection{Mechanical Properties}

The $0.76-\mathrm{mm}$-thick, as-rolled sheet was stress relieved at $700^{\circ} \mathrm{C}$ for $1 \mathrm{~h}$, followed by oil quenching. The stress-relieved sheet was punched into specimens for tensile and creep testing. In order to remove the work from die punching, all of the specimens were given a final anneal of $700^{\circ} \mathrm{C}$ followed by oil quenching prior to testing. Optical microstructures of the sheet specimens prior to testing are shown in Fig. 2.19. Tensile tests on these specimens were conducted in the temperature range of room temperature to $800^{\circ} \mathrm{C}$. Data from these tests are compared with similar data on 102-mm-diam. ingots in Fig. 2.20, which shows that the sheet processed from the 406-mm-diam. ingot has essentially the same strength and ductility 

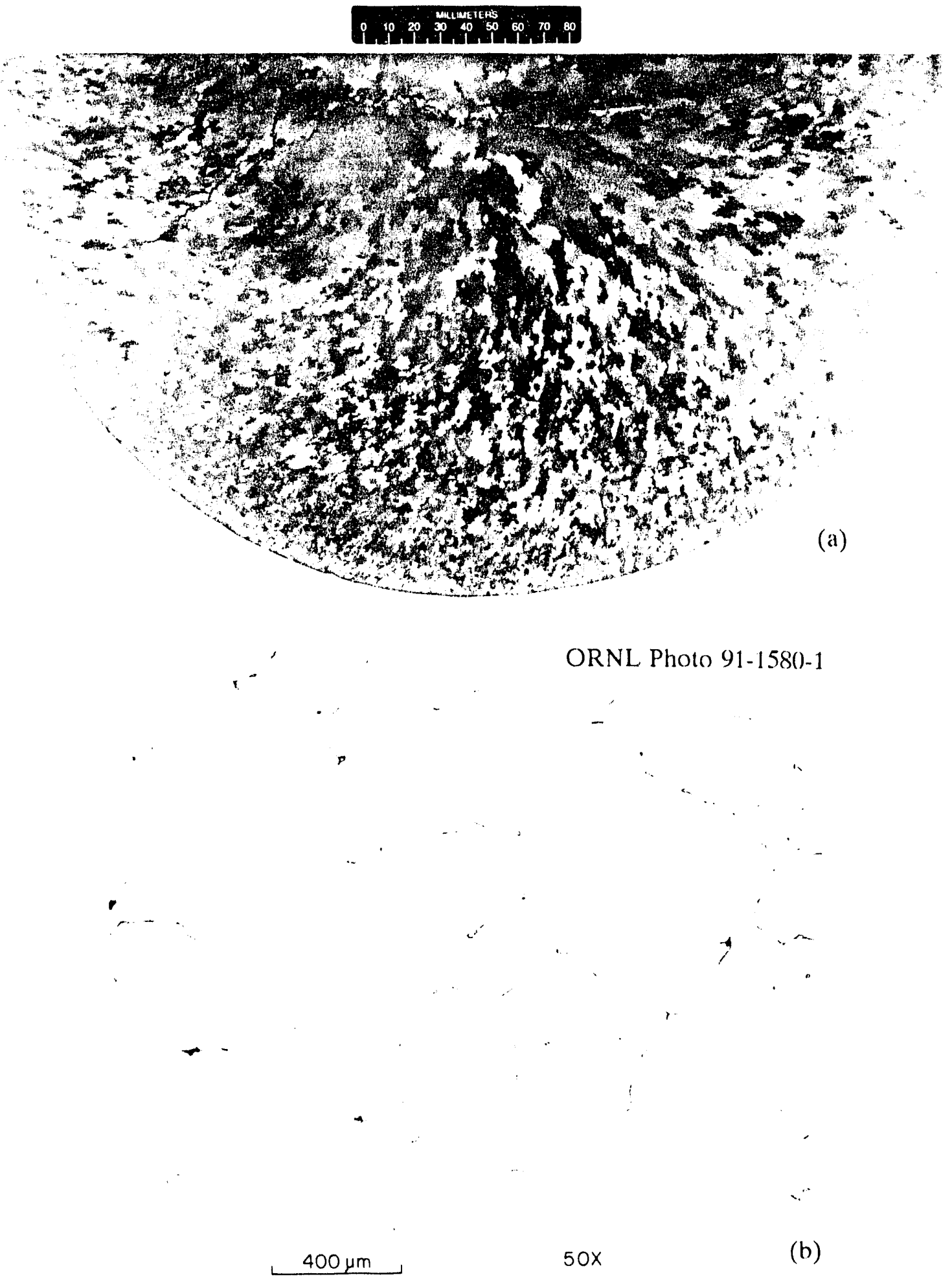

Fig. 2.17. Optical macrostructure (a) and microstructures (b,c) of a section taken from near the top of the 406-mm-diam. ESR ingot of FA-129 showing (b) grain size and secondphase distribution at low magnification, and (c) eutectic and porosity at high magnification. 
ORNL Photo 91-1580-2

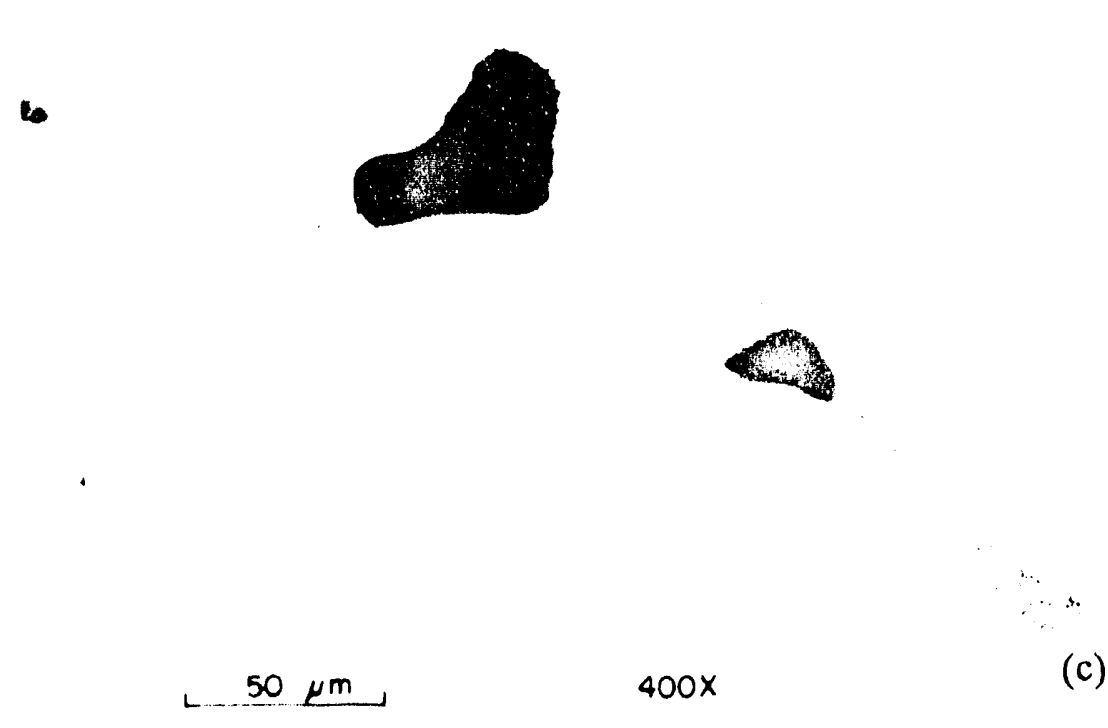

Fig. 2.17 (cont'd). Optical macrostructure (a) and microstructures (b,c) of a section taken from near the top of the 406-mm-diam. ESR ingot of FA-129 showing (b) grain size and second-phase distribution at low magnification, and (c) eutectic and porosity at high magnification.

properties as the sheet processed from the 102-mm-diam. ingots. These results are very encouraging in that they suggest that the iron-aluminide alloy FA-129 and probably alloys of other compositions can be scaled up without sacrificing tensile properties.

Creep testing of specimens from the 406-mm-diam. ESR ingot is in progress in the temperature range of 450 to $700^{\circ} \mathrm{C}$. The results of these tests will be reported in the next semiannual.

\subsubsection{Summary and Conclusions}

Our efforts at alloying between alloy FA-129 (which has good tensile properties and weldability) and alloy FA-97 (which has good high-temperature creep properties) to produce a composition which has an acceptable combination of these properties have been encouraging. Alloy FA-170 shows good weldability and creep resistance, but initial tensile properties were not as good as expected. Further studies to optimize the fabrication schedule for this alloy are underway and are expected to result in improved tensile properties. 


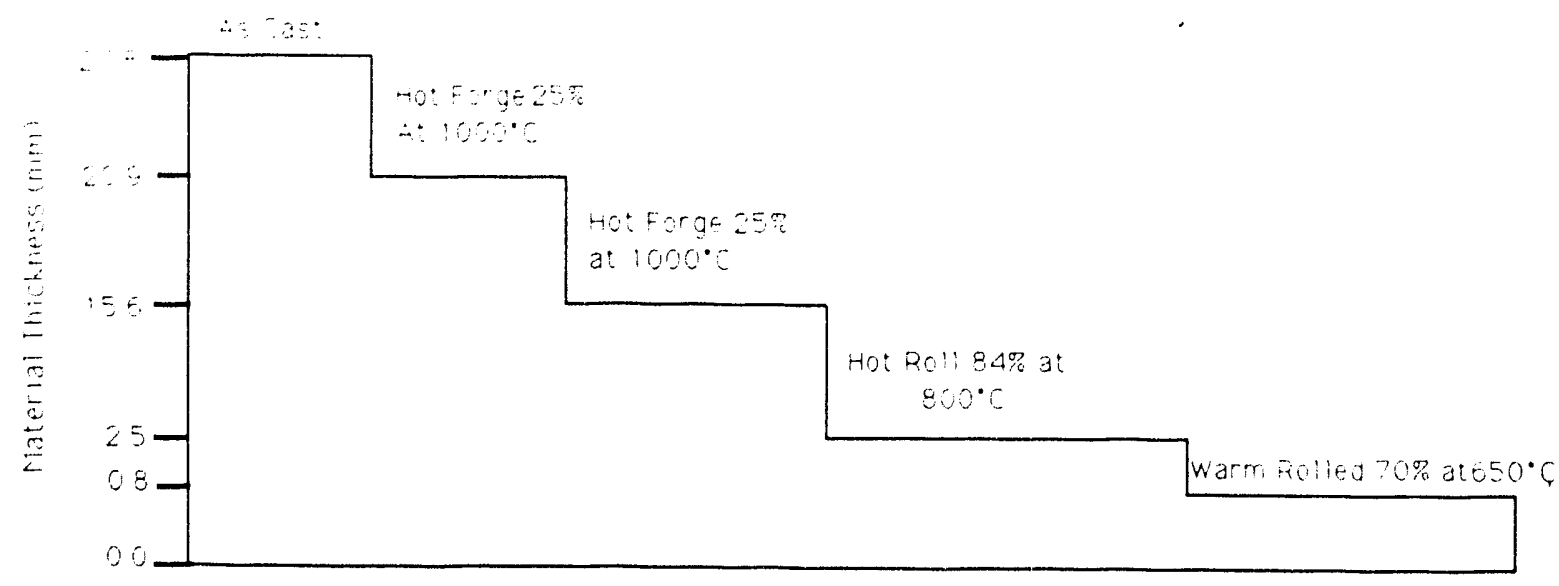

Fig. 2.18. Schematic showing the steps used for processing a section taken from near the top of the 406-mm-diam. ESR ingot of FA-129.

With the initiation in the past year of analytical electron microscopy studies on many of our alloys, we are beginning to develop an understanding of deformation mechanisms in the iron aluminides and a better understanding of the roll of alloying additions in promoting desirable properties. These studies will continue in the future.

For the first time, successful, crack-free welds were made on $12.6-\mathrm{mm}(0.5 \mathrm{in}$.) thick plate material of FA-129 alloy. Optical metallography revealed a coarse, columnar grain structure that may be detrimental to the properties of the weldment. The preliminary

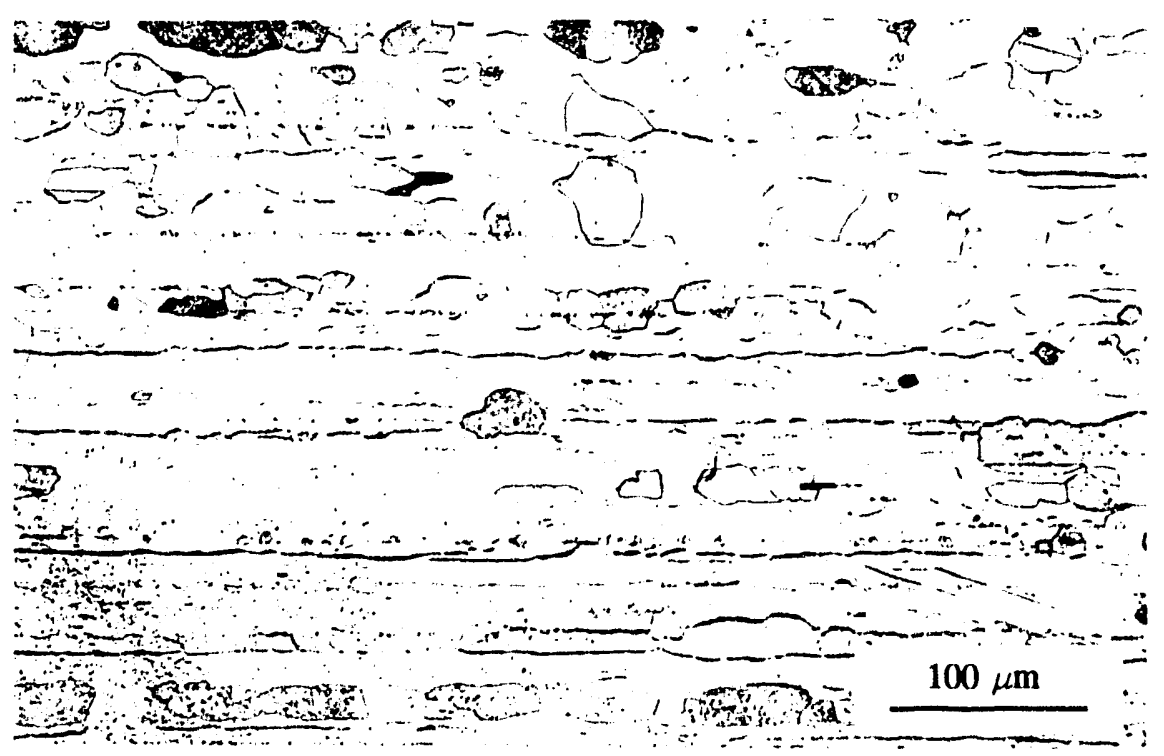

Fig. 2.19. Optical microstructure of 0.76-mm-thick sheet of alloy FA-129 prior to testing. The sheet was rolled from a section near the top of the 406-mm-diam. ESR ingot produced at Precision Rolled Products. 

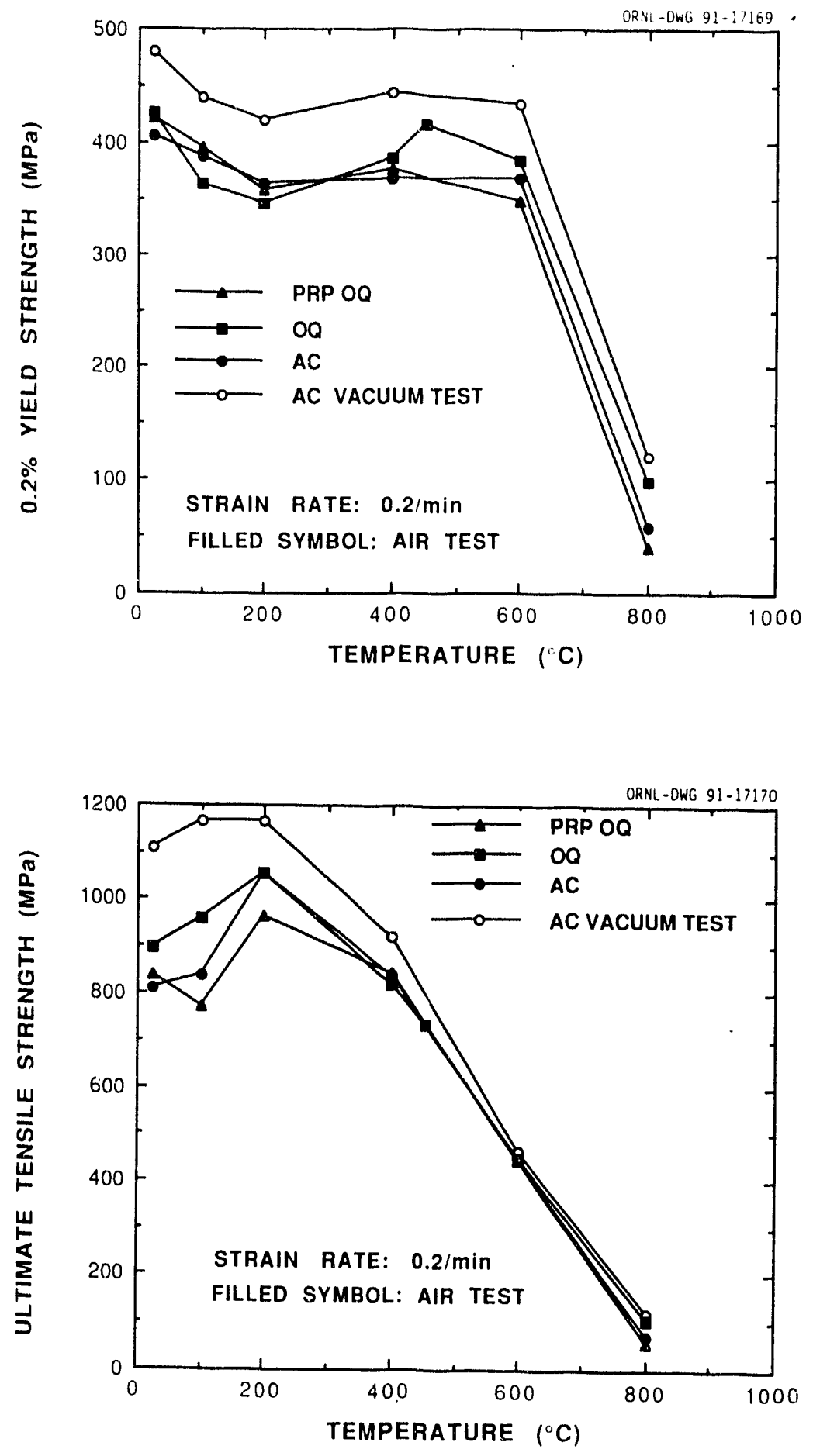

Fig. 2.20. Tensile properties of specimens from a 0.6-mm-thick sheet rolled from a section of the 406-mm-diam. ESR ingot of alloy FA-129. Data on the 406-mm-diam. ingot are compared with the previously developed data on a 102 -mm-diam. ingot of the same alloy; (a) yield strength, and (b) ultimate tensile strength. 

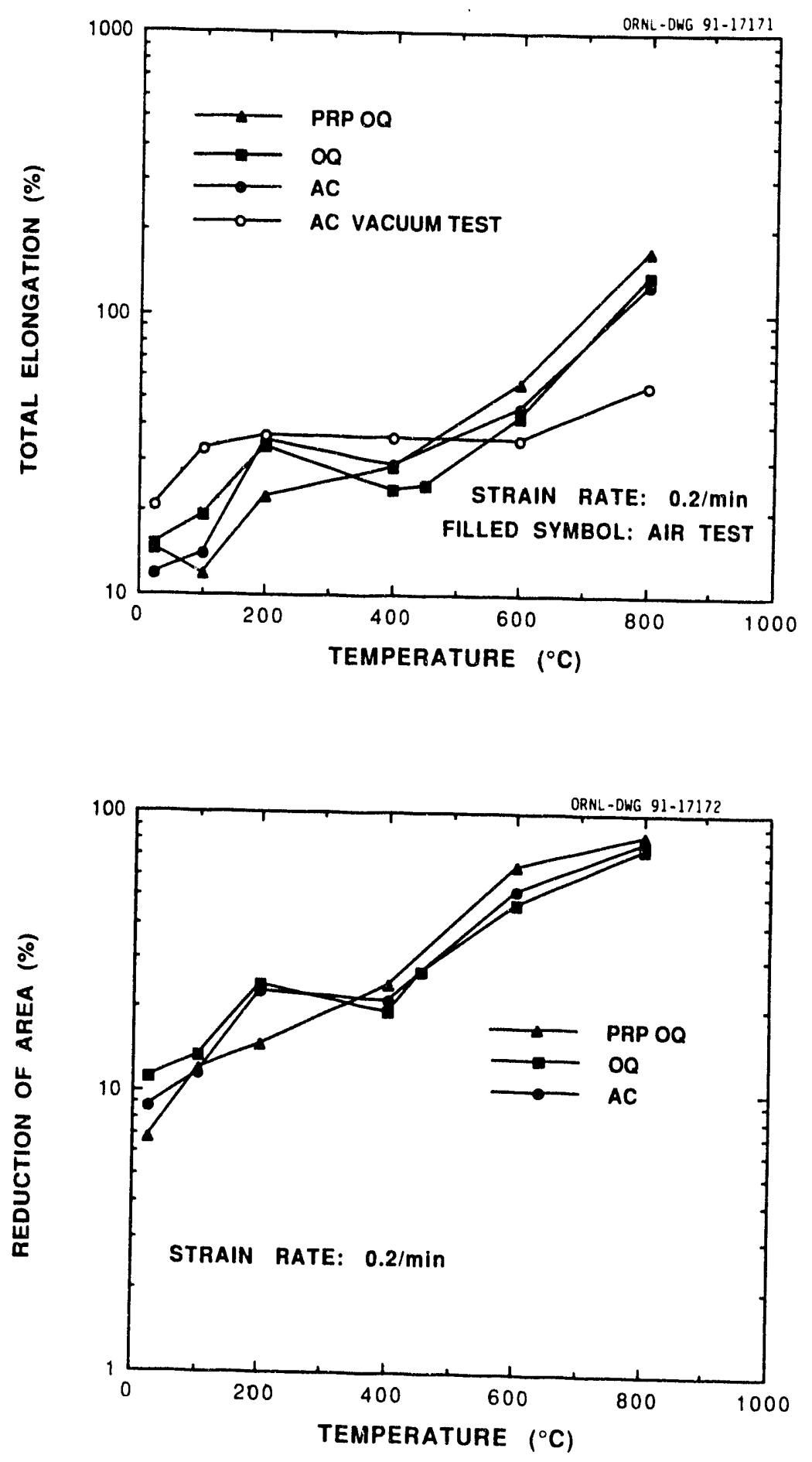

Fig. 2.20 (cont'd). Tensile properties of specimens from a $0.76-\mathrm{mm}$-thick sheet rolled from a section of the 406-mm-diam. ESR ingot of alloy RA-129. Data on the 406-mm-diam. ingot are compared with the previously developed data on a 102-mm-diam. ingot of the same alloy, (c) total elongation, and (d) reduction of area. 
weldability studies on the microalloyed iron aluminides are encouraging. Further weldability studies are essential to characterize the weldability of these materials.

The preparation of 2000- and 3000-kg heats of alloy FA-129 melted at Precision Rolled Products was described. This report also included the cutting and processing experience with one of the ingots. The macrostructure, microstructure, and tensile properties of the sheet rolled from the 406-mm-diam. ESR ingot were presented. Tensile properties of the sheet from the 406-mm-diam. ingot were compared with the sheet rolled from the 102-mm-diam. ingot produced earlier. The following conclusions were reached from the results available:

(1) No unusual problems were encountered in the preparation of the 2000 - and $3000-\mathrm{kg}$ heats of alloy FA-129 at PRP. The surface quality of the 406-mm-diam. ESR ingot was similar to that observed for other iron- and nickel-based alloys. (2) The sectioned slice from the ESR ingot showed some evidence of solidification-related cracking. (3) Small pieces from the sectioned slices were easily processable by a standard procedure developed for the laboratory-size heats. (4) Tensile properties of the sheet rolled from the 406-mm-diam. ESR ingot are similar to those observed for sheet rolled from 102-mm-diam. ingots. (5) The results presented in this study suggest that alloy FA-129 can be scaled up commercially without sacrificing tensile properties.

\subsection{References}

1. J. H. DeVan, H. S. Hsu, and M. Howell, Sulfidation/Oxidation Properties of Iron-Based Alloys Containing Niobium and Aluminum, ORNL/TM-11176, Oak Ridge National Laboratory, Oak Ridge, Tennessee, May 1989.

2. C. G. McKamey, J. H. DeVan, P. F. Tortorelli, and V. K. Sikka, J. Mater. Res. 6(8), 1779 (1991).

3. C. T. Liu, E. H. Lee, and C. G. McKamey, Scripta Metal. :23, 875-880 (1989).

4. C. T. Liu, C. G. McKamey, and E. H. Lee, Scripta Metall. 24(2), 385 (1990).

5. C. T. Liu and C. G. McKamey, High Temperature Aluminides and Intermetallics, ed. by S. H. Whang, C. T. Liu, D. P. Pope, and J. O. Stiegler (TMS, Allentown, PA, 1990), p. 133.

6. C. G. McKamey and C. T. Liu, to be published in Proceedings of ADVMAT/91 Environmental Effects on Advanced Materials Symposium, 1991.

7. V. K. Sikka, C. G. McKamey, C. R. Howell, and R. H. Baldwin, Fabrication and Mechanical Properties of $F e_{3}$ Al-Based Aluminides, ORNL/TM-11465, Oak Ridge National Laboratory, Oak Ridge, Tennessee, March 1990. 
8. C. G. McKamey and C. T. Liu, Scripta Metall. 24, 2119 (1990).

9. V. K. Sikka, SAMPE Quart. 22(4), 2 (1991).

10. C. G. McKamey, p. 197 in Proceedings of the Fourth Annual Conference on Fossil Energy Materials, Oak Ridge National Laboratory, ORNL/FMP-90/1, U.S. Department of Energy, Oak Ridge, Tennessee, August 1990.

11. D. M. Dimiduk, M. G. Mendiratta, D. Banerjee, and H. A. Lipsitt, Acta Metall. 36, 2947 (1988).

12. S. A. David, W. A. Jemian, C. T. Liu, and J. A. Horton, Weld. J. 64(1), 22s (1985).

13. S. A. David, D. N. Braski, and C. T. Liu, Weld. J. 65(4), 93s (1986).

14. S. A. David, J. A. Horton, C. G. McKamey, T. Zacharia, and R. W. Reed, Weld. J. 68(9), 372s (1989).

15. T. Zacharia and S. A. David, p. 229 in Proceedings of the Fifth Annual Conference on Fossil Energy Materials, ORNL/FMP-91/1 U.S. Department of Energy, Oak Ridge, Tennessee, September 1991.

16. V. K. Sikka, C. G. McKamey, C. R. Howell, and R. H. Baldwin, Properties of Large Heats of $\mathrm{Fe}_{3}$ Al-Based Alloys, ORNL/TM-11796, Oak Ridge National Laboratory, Oak Ridge, Tennessee, March 1991.

17. V. K. Sikka, p. 219 in Proceedings of the Fourth Annual Conference on Fossil Energy Materials, Oak Ridge National Laboratory, ORNL/FMP-90/1, U.S. Department of Energy, Oak Ridge, Tennessee, August 1990.

18. V. K. Sikka, R. H. Baldwin, K. S. Blakely, E. C. Hatfield, C. R. Howell, and C. G. McKamey, p. 197 in Proceedings of the Fifth Annual Conference on Fossil Energy Materials, ORNL/FMP-91/1 U.S. Department of Energy, Oak Ridge, Tennessee, September 1991.

19. C. G. McKamey and P. J. Maziasz, p. 175 in Proceedings of the Fifth Annual Conference on Fossil Energy Materials, ORNL/FMP-91/1 U.S. Department of Energy, Oak Ridge, Tennessee, September 1991.

20. T. Zacharia, unpublished data.

21. P. J. Maziasz and C. G. McKamey, to be published in Proceedings of International Conference on High-Temperature Aluminides and Intermetallics, J. Mater. Sci. \& Eng., 1992.

22. C. G. McKamey, P. J. Maziasz, and J. W. Jones, submitted to J. Mater. Res. 


\section{ELECTROSLAG CASTING TECHNOLOGY TRANSFER - V. K. Sikka}

\subsection{Background}

The electroslag-casting process uses the electrode of a material, which is continuously melted and cast in a water-cooled metal mold. The electrode is melted through a layer of slag which provides the I $2 R$ energy through its resistance. The slag also cleans the liquid metal of certain impurities as it passes through it. The slag forms a thin layer between the mold and the molten pool and, thus, provides noncolumnar grains. The process uses fewer steps than conventional sand casting and produces castings of excellent surface finish, internal quality, and microstructure. One major disadvantage of this technology often cited is the cost of the metal mold. This cost can only be offset if a large number of parts of the same shape are produced. The electroslag-casting technology has been well established in several Soviet commonwealth states and European countries. The purpose of this program was to revive the interest in electroslag casting in the United States. To make it interesting and different, a newly developed iron-aluminide alloy was chosen as the material of choice.

\section{Results of Industrial Contacts}

Several companies in the United States were contacted to establish the level of interest in the electroslag-casting technology. A discussion with each company is described below:

Cameron Iron Works: An earlier fossil energy-supported program had helped setup electroslag-casting equipment in the research laboratory at Cameron Iron Works. Through this program, Cameron Iron Works had proven that the equipment worked satisfactorily, and they also cast several alloy castings of a simple and rather complex shapes. Cameron Iron Works was contacted at the start of this program to see if the equipment was still functional and if they would be willing to work jointly with ORNL to further develop the electroslag-casting process. However, even after a personal visit, the research director at Cameron Iron Works said that there was no interest and indicated that the equipment was still functional; however, the engineer and the operator who operated the equipment before had left. Furthermore, the interests at Cameron Iron Works had changed and, thus, even with additional funds from the DOE program, they were not willing to do electroslag casting.

Carpenter Technology: This company has been well known for taking a lead in establishing advanced manufacturing processes. Furthermore, they have several electroslag-remelting units, which with minor changes can be used for electroslag castings. Once again, an extensive discussion with Carpenter Technology resulted in the answer that it 
did not fit into their business plan. Under a subcontract with ORNL, Carpenter did electroslag remelt an 8-in.-diam. ingot of iron-aluminide alloy FAL.

Universal Cyclops: This company has several electroslag-remelting units and, on initial contact, showed a lot of interest. As a result of their interest, a visit was made to their plant. Discussions with them resulted in a lot of technical interest, and they indicated that they could electroslag remelt the round and slab from iron-aluminide alloy. ORNL was to provide the starting electrode and the funds to do the electroslag remelting. Even when ORNL readiedthe electrode, Cyclops came back with a negative answer, saying there was no near-term, expected interest in iron aluminides.

Haynes International: Hayries has been well known for their large number of electroslag-remelting units. They were quick to say no because their primary business is nickel base and were not interested in dealing with a new alloy. Even if Haynes became interested, it would be a round shape and strictly a one-time deal.

Teledyne Alvac: Teledyne Alvac is known for their electroslag-remelting capabilities. When contacted, the response was negative. The reason cited was the interest in making very large castings of round and slab of well-established alloys.

Bhat Technology International, Inc.: Dr. Bhat was contacted to determine his input in establishing sources for electroslag casting in the United States. Dr. Bhat was extremely helpful in his discussions and even visited ORNL at Universal Cyclops and Jessop Steel. The net result of these visits was the absence of any currently operating facility for electroslag casting in the United States. Some rather complex ideas were presented for electroslag-casting work to be carried out overseas. This did not fit into the overall scope of our interest.

Special Metals Corporation: Special Metals has been well known for working with new processes and alloys. When contacted, they agreed to compare the electroslag-remelted rounds (6-in. diam.) with rounds of the same size cast by vacuum-arc remelting. This work was subcontracted and resulted in good quality electroslag-cast rounds of iron-aluminide alloy FA-129. A report on this work was written by Special Metals and subsequent testing at ORNL has resulted in two technical papers. Special Metals was sufficiently encouraged with the initial results in that further discussions could result in the making of shapes from iron-aluminide alloys as required. These discussions are currently under way.

Precision Rolled Products: This company was the most supportive of the idea of preparing the electrodes and electroslag remelting. They agreed to initially prepare the 
electroslag-remelted rounds with subsequent possibilities for shapes. The contract with Precision Rolled Products, which was cost shared by them, resulted in the preparation of a 16-in.-diam. electroslag-remelted ingot of iron-aluminide alloy FA-129. It also resulted in the preparation of an 8-in.-thick by 32-in.-wide slab electrode for electroslag remelting. Both the round and slab are of acceptable quality and are currently under testing in both the as-cast and after processing conditions. Discussions are now under way with Precision Rolled Products for cast shapes.

\section{RESPONSES OF METALLIC AND OXIDE SURFACES TO DEFORMATION - \\ M. Rao, J. R. Keiser, and P. F. Tortorelli}

This project was divided into two tasks. The first, on erosion studies, addresses the deformation of metals and alloys during erosion and erosion-corrosion. The second task consists of a study of the mechanical properties of oxide scales formed on the surface of selected metals and alloys.

\subsection{Erosion Studies}

During the past six months, the results of a seven year experimental program to examine erosion mechanisms in metallic alloys ${ }^{1.7}$ were analyzed and the principal findings and conclusions are summarized here. These studies involved a fundamental approach to examining erosion mechanisms by experimentally modelling the process using realistically sized single particles as well as by examining material deformation and flow in multiple particle erosion tests. Spherical particles were used in all the tests in order to facilitate analysis by maintaining a simple impact geometry. Studies were conducted from the perspective of how material properties, and especially mechanical properties, control their response to particulate impacts. Results of the two types of experiments were compared and correlated.

Two gas guns were built and used for the single particle impact studies. The first gun, built at the program's initiation, is attached to a scanning electron microscope (SEM) and fires $343 \mu \mathrm{m}$ spheres at velocities between $10-60 \mathrm{~m} / \mathrm{s}^{1}$ The second gun, built in the sixth year of the program, fires sabots in air at velocities between $200-1000 \mathrm{~m} / \mathrm{s}$. The two guns were used to fire $343 \mu \mathrm{m}$ diameter WC spheres at various targets oriented at $30^{\circ}$ or $90^{\circ}$ to the impacting particle.

Initial studies using the SEM gas gun showed that larger craters formed in softer alloys, but crater size could not be related to relative erosion rates. Mechanical properties microprobe (MPM) measurements showed work hardening due to impacts, but no thermal 
effects were evident for impacts at velocities around $30 \mathrm{~m} / \mathrm{s}$ on a series of aluminum alloys. The depth of hardening was less in the stronger 7075-T6 alloy compared to $1100 \mathrm{Al}$. The significantly softer $1100 \mathrm{Al}$ had shown superior erosion resistance in other studies, suggesting that the capacity to distribute the impact energy over large volumes improved a material's erosion resistance. Detailed single impact studies over a wide range of velocities were conducted on targets of $1100 \mathrm{Al}$ and a $\mathrm{Fe}_{3} \mathrm{Al}$-based ordered iron aluminide alloy, FA-129, in both heat treated and cold-worked conditions. For impacts at velocities around $60 \mathrm{~m} / \mathrm{s}$, craters were larger in the softer $1100 \mathrm{Al}$ and the amount of material hardened by the impacts was less in the iron aluminide alloy, but the difference was less than expected based on the hardness differential between the two alloys. In some cases, at velocities of several hundred meters per second, the depth of hardening was greater in the iron aluminide alloy. Near-surface softening was observed in the cold-worked iron aluminide alloy, and possibly in annealed $1100 \mathrm{Al}$, at velocities around $60 \mathrm{~m} / \mathrm{s}$. Near-surface softening was observed in both alloys for impacts at velocities of several hundred meters per second, although the softening effects could be identified more clearly in the iron aluminide alloy. This softening was also observed due to moderately low velocity impacts on surfaces of previously eroded-corroded $2.25 \mathrm{Cr} 1 \mathrm{Mo}$ steels, supporting the argument that greater softening occurred in more deformation resistant materials.

MPM measurements showed that for $30^{\circ}$ incidence, more material was hardened in front of the impacting ball than vertically beneath the crater. Unlike at low velocities, significant differences were seen in the appearance of single impact craters at $30^{\circ}$ incidence between $1100 \mathrm{Al}$ and the iron aluminide alloy. Well developed extruded lips were formed in $1100 \mathrm{Al}$, with considerable deformation around the impact site but no material removal. In contrast, the extruded lip in the iron aluminide alloy fractured at the exit edge of the crater, perhaps due to low ductility in the material (around 15\%) compared to annealed $1100 \mathrm{Al}$ (35\%). The velocity at which the extruded lips failed in the iron aluminide alloy was not well defined. In contrast, no difference was seen in the appearance of craters or extruded lips in annealed and cold-worked $1100 \mathrm{Al}$, even though the ductility was reduced from $35 \%$ to $6 \%$ upon cold-working.

To allow comparison with the single particle impact studies, multiple particle erosion studies were conducted at a velocity of $45 \mathrm{~m} / \mathrm{s}$ using steel shot either $600-700 \mu \mathrm{m}$ in diameter (earlier studies) or $297-420 \mu \mathrm{m}$ in diameter (later studies). The first study was conducted on 
$1100 \mathrm{Al}$ and 7075-T6 $\mathrm{Al}$, to examine the surface ripple structure that developed during erosion at $30^{\circ}$ incidence. A work hardened layer was observed in both materials, with a maximum hardness greater than observed in single particle impact studies and no evidence of near-surface softening. Wave crests and valleys were identified and it was found that the depth of hardening under a wave crests extended to a distance equal to the height of the wave crest plus the depth of hardening beneath a valley. The depth of hardening beneath a valley was similar to that under single particle impacts.

The development of a ripple structure at $30^{\circ}$ incidence and a hill-and-valley structure at $90^{\circ}$ incidence was examined in detail for $1100 \mathrm{Al}$. It was found that the surface structures developed early in the erosion process and several overlapping impacts were necessary to achieve maximum strain hardening on the surface. The material continued to accumulate strain without fracture after the maximum flow stress was achieved. As in the earlier study, hardening extended to much greater depths under wave crests for erosion at $30^{\circ}$ incidence, supporting the view that strain hardened material was pushed up from the wave valleys into the crests. In contrast, for erosion at $90^{\circ}$ incidence, the depth of hardening was approximately equal beneath hills and valleys. Significant embedment of erodent fragments, predominantly in the valleys, occurred for erosion at $90^{\circ}$. Deformation contours showed material being back-extruded from valleys into the hills, but most of this movement occurred near the surface rather than through the bulk of the material, leading to the observed hardness distribution. No near-surface softening was evident beneath the eroded surfaces of $1100 \mathrm{Al}$ at either $30^{\circ}$ or $90^{\circ}$ incidence. However, there was some evidence for a constant hardness in the near-surface layers, especially at $90^{\circ}$ incidence. Material removal was controlled by the attainment of a critical fracture strain and occurs due to overlapping impacts or by the fracture of lips of material extruded from wave crests.

The surface structure apparently initiated due to locally high concentrations of impacts leading to incipient hills or wave crests which persist because the impact energy is distributed over smaller volumes in the highly strain hardened material. The hills/crests grow since for $30^{\circ}$ impacts most of the hardened material is pushed in front of the impacting particle and for $90^{\circ}$ impacts, a higher concentration of voids and fissures associated with particle embedment lead to greater deformation in valley regions. The peak hardness in valley regions were sometimes less than on hills/crests, perhaps due to recent material movement out of the 
valleys. The structures continue to grow until material removal rates from hills/crests and valleys are balanced.

Surface structure is expected to be strongly influenced by target material strength and ductilities, developing to a greater extent on softer, more deformable materials. The spacings of the features are expected to be related to the range of deformation associated with an impact, and therefore to particle size (as has been observed) as well as to the impact velocity. Within the same family of alloys, the development of ripples or hills and valleys may contribute to increased erosion resistance due to longer incubation periods, greater absorption of the incident energy in material deformation and movement processes and possible shielding from impact of low lying areas by neighboring elevated regions.

Taper-sectioning was shown to be a powerful technique to examine the near-surface deformation of eroded surfaces. However, the technique has to be used judiciously and results analyzed carefully in order to avoid misinterpretation of the data.

The multiple particle erosion of the iron aluminide alloy FA-129 by steel shot was also examined in detail. It was found that erosion occurred even though most of the impacting particles were softer than the target material. Softer spherical particles appeared to merely form an impression on the target surface whereas harder particles formed extruded lips, especially under oblique impact. Two distinct erosion mechanisms were observed: extrusion and fracture of platelets by the impact of spherical particles and a cutting or gouging out of rnaterial by the impact of angular particles which were present in the shot as well as formed by fragmentation upon impact of an oxide scale covering many of the particles. The platelets and extrusions were relatively small and angular particles had more damage associated with eacin impact event. Both mechanisms were observed at $30^{\circ}$ incidence but damage by angular particles and debris dominated at higher angles. The steady state erosion rates were roughly equal at $30^{\circ}$ and $60^{\circ}$ incidence with some indication that the steady state rate at $90^{\circ}$ may also be similar, due to a complex balance of the extent of platelet formation and cutting at the various angles.

The alloy work hardened significantly under impacts at both $30^{\circ}$ and $90^{\circ}$ incidence. Unlike $1100 \mathrm{Al}$, the hardness dropped off in near-surface layers, and the thickness of this softened layer increased with erodent dose. Also unlike $1100 \mathrm{Al}$, the value of the peak subsurface hardness was similar to that under single particle impacts. The depth of overall work hardening as well as the thickness of the softened near-surface layer were both greater 
for erosion at $90^{\circ}$ because a greater fraction of the energy of impacting particles was transferred to the target. The angular dependance of the depth of hardening was less pronounced in $1100 \mathrm{Al}$, implying that in softer, more deformable materials, a larger fraction of the impact energy is expended in moving material and developing the surface topography.

The surface of the iron aluminide did not develop features observed on eroded $1100 \mathrm{Al}$, suggesting limited ductility under the erosion test conditions. The platelets and extrusions created by the impinging shot were also small, implying an inability of the material to sustain large plastic strains. However, there were no signs of cracks or delaminations that would indicate macroscopic brittle failure in the material. The near-surface layers of the iron aluminide alloy were found to be in a disordered state after erosion. However, the effect of this phase transformation on the erosion process was not clear. Data from available literature showed that the aluminides may have an erosion resistance comparable to other engineering alloys and the overall results indicate relatively good resistance of iron aluminides to solid particle erosion which may be improved by increasing the alloy's ductility.

In the case of the iron aluminide alloy, the maximum hardness reached was similar in single and multiple particle impact studies. However, in $1100 \mathrm{Al}$, the flow stress built up over several impacts. Increasing the velocity of the single impact caused near-surface softening before the maximum flow stress was achieved. This indicated possible thermal effects. Single particle impact studies at high velocities were found to correlate well with results from low velocity multiple particle erosion experiments. It was found that although a single impact can remove material at high velocities, the several overlapping impacts needed to remove material at relatively low velocities expend less overall energy due to strain localization effects in the extruded lips formed on impact. Single particle impacts will therefore tend to underestimate the erosion rate.

Relatively early material loss in the iron aluminide alloy in both single and multiple particle impact tests could be related to its lower ductility as well as its propensity to localize deformation due to its ordered nature. In contrast, the high dynamic recovery and stacking fault energy of $1100 \mathrm{Al}$ allowed impact energy and deformation to be spread more uniformly, explaining the lack of brittle failure observations in cold-worked $1100 \mathrm{Al}$ even though ductility was greatly reduced.

The mechanical properties of a material alone could not be consistently explain the observed deformation behavior and material removal under the various impact conditions. 
Contrary to what is generally assumed, the volume of deformed material due to an impact was significantly larger than the crater volume. It was shown that elastic-plastic contact mechanics did not accurately predict the similarity in hardening depths between the heat treated and cold-worked $1100 \mathrm{Al}$ and iron aluminide alloys for impact around $60 \mathrm{~m} / \mathrm{s}$, and that influences other than pure mechaniral properties effects were important at these velocities.

Residual stress effects explained the occurrence of near-surface softening in the iron aluminide alloy but could not satisfactorily explain the hardening behavior observed for single particle impacts at various velocities. Thermal effects could more completely explain the results based on the argument that at moderate velocities, strong dynamic recovery effects in $1100 \mathrm{Al}$ promote the development of a constant flow stress whereas localization of deformation in the iron aluminide alloy promote dynamic recrystallization effects, leading to near-surface softening. At very high velocities, stronger thermal effects dominated over dynamic recovery effects in $1100 \mathrm{Al}$, leading to near-surface softening, probably due to recrystallization from residual heat. At low velocities, thermal effects no longer dominate and the impact response is controlled mainly by the mechanical properties of the alloy. Thermal effects may be expected to be significant over a significant portion of the velocity range for erosion applications. However, at any velocity, thermal effects will be less important for impacts with angular particles compared to spherical. Since thermal effects need not necessarily create a soft surface layer, erosion conditions have to be analyzed carefully to anticipate possible effects.

Thermal effects could explain lack of difference in hardening depths between the two alloys for moderately low velocity single impacts and the higher hardening depth in the iron aluminide alloy for high velocity single impacts. It was estimated that clear evidence of thermal effects in $1100 \mathrm{Al}$ during multiple particle impact experiments would be seen under experimental conditions somewhat more severe than in the present study.

Potential areas for future work include erosion studies in iron aluminide alloys using angular particles, erosion induced order-disorder transformations in iron aluminide alloys, residual stress effects during erosion and high velocity single impact studies on various aluminum alloys or steels to study relative influence of mechanical properties and thermal effects on erosion. 


\subsection{Mechanical Properties of Oxide Scales}

The mechanical properties of protective oxide scales are being characterized based on the premise that properties such as hardness, modulus, etc., ultimately determine whether a chemically stable surface oxide will retain its integrity in corrosive, high-temperature environments and, thus, whether a particular high-temperature alloy is generally corrosion resistant. A mechanical properties microprobe (MPM) is being used to measure hardness, Young's modulus, and plasticity of alumina and chromia scales and bulk oxides by depth-sensing submicron indentation testing. During the current reporting period, emphasis was placed on the development of methodologies for measuring the mechanical properties of thin oxide scales by focusing on a greater in-depth analysis of the various MPM data sets.

It was previously shown ${ }^{8}$ that while, in general, the MPM data did fall within the expected range and good precision was found, there was a significant variation among the moduli of four polycrystalline specimens of bulk alumina. Several of these values, as well as the measured moduli $(E)$ and hardnesses $(H)$ of sapphire, were higher than those reported in the literature. ${ }^{8}$ Because the determinations of $\mathrm{H}$ and $\mathrm{E}$ strongly depend on the modeling of the indenter contact area, errors in the calculation due to surface roughness or the specific analytical approach to the estimation of the indenter tip shape have to be considered because they can lead to different results for the same material. However, this type of factor would not explain the specimen to specimen variation ${ }^{8}$ because all the specimens had similar surface finishes and the same model was used for the properties determinations. Furthermore, recent calculations of the values of $\mathrm{H} / \mathrm{E}^{2}$, which does not depend on knowledge of indenter contact area, ${ }^{9}$ showed that such estimation errors were not the cause of the scatter for a particular alumina specimen nor of the differences among them. Therefore, based on this finding and previous observations, ${ }^{8}$ it is thought that the variability among different sets more likely arises from errors in the determination of the machine compliance, and/or other instrument changes. ${ }^{10,11}$ Better control over some of these factors, as well as the use of standards for checking reproducibility over a period of time, may well reduce the specimen-to-specimen variation.

MPM results for chromia scales grown on chromium showed substantially greater scatter (in $\mathrm{H}$ and $\mathrm{E}$ ) than those for other scales and bulk oxides., ${ }^{8,12}$ It was therefore decided to reanalyze the data using the final unloading curves rather than the series of unloading curves gotten during the loading cycles. ${ }^{13}$ The results (shown in Table 2.11 ) yielded a more realistic 
value of the elastic modulus (averaged over several successful indentations) and a smaller standard deviation. Further evaluation of the differences between the two analysis techniques will be required to determine the best measurement approach.

In FY 1992, the measurements of the mechanical properties of thin oxide scales will no longer be a separate task. Rather, such work will constitute one part of the overall characterization efforts being performed in support of the development of corrosion-resistant iron aluminides and ultrahigh strength high temperature intermetallics.

Table 2.11. Hardness, Young's Modulus, and ratio of plastic to total indentation depth (PD/ID) as determined using the mechanical properties microprobe

\begin{tabular}{lccc}
\hline Type & $\begin{array}{c}\mathrm{H} \\
(\mathrm{GPa})\end{array}$ & $\begin{array}{c}\mathrm{E} \\
(\mathrm{GPa})\end{array}$ & PD/ID \\
\hline Scale on $\mathrm{Cr}$ & $30 \pm 9$ & $318 \pm 52$ & $0.69 \pm 0.04$ \\
Bulk Chromia & $37 \pm 4$ & $275 \pm 17$ & $0.60 \pm 0.02$ \\
Unoxidized $\mathrm{Cr}$ & $6 \pm 1$ & $129 \pm 5$ & $0.83 \pm 0.01$ \\
\hline
\end{tabular}

\section{References}

1. J. R. Keiser, Design, Construction, and Initial Results for an Erosion-Corrosion Test System, ORNL/TM-10049, Oak Ridge National Laboratory, Oak Ridge, Tennessee, May 1986.

2. J. R. Keiser, p. 345 in Proc. Conf. on Corrosion-Erosion-Wear of Materials at Elevated Temperatures, A. V. Levy (ed.), National Association of Corrosion Engineers, Houston, TX, (1987) 345 .

3. J. R. Keiser, R. C. Heidersbach, D. L. Dobbs, Jr., and W. C. Oliver, Wear 124 (1988) 105.

4. J. R. Keiser, R. C. Heidersbach, D. L. Dobbs, Jr., and W. C. Oliver, J. Mater. Eng., 10 (1988) 273.

5. M. Rao, J. Keiser and D. Wilson, Scripta Met. 23 (1989) 1475.

6. J. R. Keiser, D. F. Wilson, J. N. Hines and A. V. Levy, J. Mater. Eng. 12 (1990) 245.

7. M. Rao, J. R. Keiser and D. F. Wilson, "Subsurface Hardening and Flow of Aluminum During the Incubation Period of Solid Particle Erosion, to be published in Proc. 4th Berkeley Conf. on Corrosion-Erosion-Wear of Materials at Elevated Temperatures, National Association of Corrosion Engineers, Houston, Texas. 
8. P. F. Tortorelli and J. R. Keiser, p. 377 in Proc. 5th Annual Conf. Fossil Energy Materials, N. C. Cole and R. R. Judkins (comp.), ORNL/FMP-91/1, Oak Ridge National Laboratory, Oak Ridge, Tennessee, September 1991.

9. D. L. Joslin and W. C. Oliver, J. Mater. Res. 5 (1990) 123.

10. W. C. Oliver and G. M. Pharr, "An Improved Technique For Determining Hardness and Modulus Using Depth Sensing Microcontact Experiments," to be submitted for publication in J. Mater. Res., 1991.

11. M. E. O'Hern, Nano Instruments, Inc., Knoxville, Tennessee, private communication, May 1991.

12. P. F. Tortorelli, J. R. Keiser, K. R. Willson, and W. C. Oliver, p. 271 in Microscopy of Oxidation, M. J. Bennett and G. W. Lorimer (eds.), The Institute of Metals, London, United Kingdom, 1991.

13. W. D. Nix, Metall. Trans. A 20A (1989) 2217-2245.

\section{COAL CONVERSION AND UTILIZATION PLANT SUPPORT SERVICES - J. R. Keiser}

During this period, support services were provided to several facilities. Assistance was provided to the staff of a coal gasification plant to help identify a means to eliminate corrosion in a distillation column. Corrosion samples were prepared for exposure in the reactor of a Japanese coal liquefaction facility, and samples provided by the Japanese were prepared for exposure in the two reactor vessels at the Wilsonville, Alabama, Coal Liquefaction Research and Development Facility.

\subsection{Coal Gasification}

In May of this year, ORNL engineers were informed of a serious corrosion problem in a phenol distillation tower at the coal gasification plant located in Beulah, North Dakota. This facility was formerly known as the Great Plains Coal Gasification Plant, and is now operated by the Dakota Gasification Company.

The phenol distillation tower is part of the phenol separation facility which was constructed to permit separation of phenol (hydroxybenzene) and cresylic acids (generally defined as a mixture of multiply substituted hydroxybenzenes so that the boiling point is in the range $220-250^{\circ} \mathrm{C}$ ), both of which can be sold corsmercially. The phenol separation facility began operation in December, 1990, and operated for a total of about 130 days. The phenol distillation tower along with the other two towers in the facility are constructed of $304 \mathrm{~L}$ 
stainless steel; nevertheless, considerable thinning of column trays was detected and operation was discontinued.

An ORNL staff member twice visited the gasification plant to inspect the corroded vessel and to discuss investigation of the problem with plant engineers and chemists. To assist in investigation of the corrosion problem, ORNL provided five racks of corrosion coupons which were exposed during a 24-day period in June and July when the phenol separation facility was operated. These racks of coupons were mounted on manway covers at five locations chosen to bracket the region where the most severe corrosion was expected. Corrosion rate calculations based on coupon weight changes are given in Tables 2.12-2.16. These results indicate that the most severe corrosion occurred between trays 40 and 60 and probably reached about $0.76 \mathrm{~mm} / \mathrm{y}$ (30 mil/y) on $304 \mathrm{~L}$ stainless steel. Based on the coupon studies, Carpenter $20 \mathrm{Cb} 3$ and Incoloy 825 were identified as materials that were very resistant to corrosion in the phenol tower environment. The high molybdenum content austenitic stainless steels showed good corrosion resistance, and, quite surprisingly, carbon steel consistently corroded at a lower rate than the chromium-molybdenum steels.

Results of extensive studies conducted by personnel of the gasification plant provided guidance as to means to remove the corrodent from the process streams. The corrosion coupons were returned to the plant for further exposure during a period when steps were taken to remove the corrodent.

\subsection{Coal Liquefaction}

An agreement between the U.S. Department of Energy (DOE) and the Japanese Agency for Inilustrial Science and Technology (AIST) calls for each country to provide corrosion samples for exposure in coal liquefaction plants operated by the other country. On behalf of AIST, two sets of samples were sent to ORNL where they were measured, weighed, and mounted on racks suitable for the two reactors vessel in the Wilsonville facility. These sample racks were delivered to Wilsonville in early September. Following exposure, the samples will be returned to ORNL for examination.

A set of samples was prepared by ORNL personnel for exposure in the Japanese coal liquefaction reactor. The compositions of these samples which were shipped to Japan in early September are listed in Table 2.17. Exposure of these samples is scheduled to begin in September, and they will be examined by the Japanese following exposure. 
Table 2.12. Calculated corrosion rates for coupons exposed 576 hours at the manway below tray 1 in the phenol distillation tower of the Dakota Gasification Company's Beulah, North Dakota plant.

\begin{tabular}{|c|c|c|}
\hline \multirow[t]{2}{*}{ Material } & \multicolumn{2}{|c|}{ Corrosion Rate } \\
\hline & $\mathrm{m} \mathrm{m} / \mathrm{y}$ & $\mathrm{mil} / \mathrm{y}$ \\
\hline $\begin{array}{l}2.25 \mathrm{Cr}-1 \mathrm{Mo} \\
5 \mathrm{Cr}-1 \mathrm{Mo} \\
\text { Modified } 9 \mathrm{Cr}-1 \mathrm{Mo}\end{array}$ & $\begin{array}{l}0.071 \\
0.063 \\
0.419\end{array}$ & $\begin{array}{r}2.8 \\
2.5 \\
16.5\end{array}$ \\
\hline $\begin{array}{l}\text { 7Cr-1Mo } \\
\text { Type } 410 \text { Stainless Steel } \\
\text { Type } 321 \text { Stainless Steel }\end{array}$ & $\begin{array}{l}0.271 \\
<0.003 \\
<0.003\end{array}$ & $\begin{array}{l}10.6 \\
<0.1 \\
<0.1\end{array}$ \\
\hline $\begin{array}{l}\text { Carbon Steel } \\
\text { Type } 304 \mathrm{~L} \text { Stainless Steel } \\
\text { Type } 310 \text { Stainless Steel }\end{array}$ & $\begin{array}{l}0.016 \\
<0.003 \\
<0.003\end{array}$ & $\begin{array}{l}0.6 \\
<0.1 \\
<0.1\end{array}$ \\
\hline $\begin{array}{l}\text { Type } 316 \mathrm{~L} \text { Stainless Steel } \\
\text { Type } 317 \text { Stainless Steel } \\
\text { Ferralium }\end{array}$ & $\begin{array}{l}<0.003 \\
<0.003 \\
<0.003\end{array}$ & $\begin{array}{l}<0.1 \\
<0.1 \\
<0.1\end{array}$ \\
\hline $\begin{array}{l}\text { Type } 317 \mathrm{LM} \text { Stainless Steel } \\
\text { Incoloy } 8235 \\
\text { Carpenter } 20 \mathrm{Cb} 3\end{array}$ & $\begin{array}{l}<0.003 \\
<0.003 \\
<0.003\end{array}$ & $\begin{array}{l}<0.1 \\
<0.1 \\
<0.1\end{array}$ \\
\hline
\end{tabular}

Table 2.13. Calculated corrosion rates for coupons exposed 576 hours at the manway located at tray 20 in the phenol distillation tower of the Dakota Gasification Company's Beulah, North Dakota plant.

\begin{tabular}{|c|c|c|}
\hline \multirow[t]{2}{*}{ Material } & \multicolumn{2}{|c|}{ Corrosion Rate } \\
\hline & $\mathrm{m} \mathbf{m} / \mathbf{y}$ & $\mathrm{mil} / \mathrm{y}$ \\
\hline $\begin{array}{l}2.25 \mathrm{Cr}-1 \mathrm{Mo} \\
5 \mathrm{Cr}-1 \mathrm{Mo} \\
\text { Modified } 9 \mathrm{Cr}-1 \mathrm{Mo}\end{array}$ & $\begin{array}{l}1.706 \\
1.448 \\
1.385\end{array}$ & $\begin{array}{l}67.1 \\
57.0 \\
54.5\end{array}$ \\
\hline $\begin{array}{l}\text { 7Cr-1Mo } \\
\text { Type } 410 \text { Stainless Steel } \\
\text { Type } 321 \text { Stainless Steel }\end{array}$ & $\begin{array}{l}1.252 \\
0.469 \\
0.405\end{array}$ & $\begin{array}{l}49.3 \\
18.4 \\
15.9\end{array}$ \\
\hline $\begin{array}{l}\text { Carbon Steel } \\
\text { Type } 304 \mathrm{~L} \text { Stainless Steel } \\
\text { Type } 210 \text { Stainless Steel }\end{array}$ & $\begin{array}{l}0.393 \\
0.218 \\
0.066\end{array}$ & $\begin{array}{r}15.4 \\
8.6 \\
2.6\end{array}$ \\
\hline $\begin{array}{l}\text { Type } 316 \mathrm{~L} \text { Stainless Steel } \\
\text { Type } 317 \text { Stainless Steel } \\
\text { Ferralium }\end{array}$ & $\begin{array}{l}0.062 \\
0.062 \\
0.051\end{array}$ & $\begin{array}{l}2.4 \\
2.1 \\
2.0\end{array}$ \\
\hline $\begin{array}{l}\text { Type } 317 \mathrm{LM} \text { Stainless Steel } \\
\text { Carpenter } 20 \mathrm{Cb} 3 \\
\text { Incoloy } 825\end{array}$ & $\begin{array}{r}0.008 \\
<0.003 \\
<0.003\end{array}$ & $\begin{array}{r}0.4 \\
<0.1 \\
<0.1\end{array}$ \\
\hline
\end{tabular}


Table 2.14. Calculated corrosion rates for coupons exposed 576 hours at the manway located at tray 40 in the phenol distillation tuwer of the Dakota Gasification Company's Beulah, North Dakota plant.

\begin{tabular}{|c|c|c|}
\hline \multirow[t]{2}{*}{ Material } & \multicolumn{2}{|c|}{ Corrosion Rate } \\
\hline & $\mathrm{m} \mathrm{m} / \mathrm{y}$ & $\mathrm{mil} / \mathrm{y}$ \\
\hline $\begin{array}{l}2.25 \mathrm{Cr}-1 \mathrm{Mo} \\
5 \mathrm{Cr}-1 \mathrm{Mo} \\
\text { Modified } 9 \mathrm{Cr}-1 \mathrm{Mo}\end{array}$ & $\begin{array}{l}3.349 \\
2.830 \\
2.690\end{array}$ & $\begin{array}{l}131.0 \\
111.0 \\
105.0\end{array}$ \\
\hline $\begin{array}{l}7 \mathrm{Cr}-1 \mathrm{Mo} \\
\text { Type } 410 \text { Stainless } \\
\text { Type } 321 \text { Stainless } \\
\text { Steel }\end{array}$ & $\begin{array}{l}2.645 \\
0.755 \\
0.715\end{array}$ & $\begin{array}{r}104.0 \\
29.7 \\
28.1\end{array}$ \\
\hline $\begin{array}{l}\text { Carbon Steel } \\
\text { Type } 304 \mathrm{~L} \text { Stainless Steel } \\
\text { Type } 310 \text { Stainless Steel }\end{array}$ & $\begin{array}{l}0.504 \\
0.728 \\
0.155\end{array}$ & $\begin{array}{r}19.8 \\
28.6 \\
6.1\end{array}$ \\
\hline $\begin{array}{l}\text { Type } 316 \mathrm{~L} \text { Stainless Steel } \\
\text { Type } 317 \text { Stainless Steel } \\
\text { Ferralium }\end{array}$ & $\begin{array}{l}0.263 \\
0.053 \\
0.181\end{array}$ & $\begin{array}{r}10.3 \\
2.1 \\
7.2\end{array}$ \\
\hline $\begin{array}{l}\text { Type } 317 \mathrm{LM} \text { Stainless Steel } \\
\text { Carpenter } 20 \mathrm{Cb} 3 \\
\text { Incoloy } 825\end{array}$ & $\begin{array}{r}0.003 \\
<0.004 \\
<0.003\end{array}$ & $\begin{array}{r}0.1 \\
0.2 \\
<0.1\end{array}$ \\
\hline
\end{tabular}

Table 2.15. Calculated corrosion rates for coupons exposed 576 hours at the manway located at tray 60 in the phenol distillation tower of the Dakota Gasification Company's Beulah, North Dakota plant.

\begin{tabular}{|c|c|c|}
\hline \multirow[t]{2}{*}{ Material } & \multicolumn{2}{|c|}{ Corrosion Rate } \\
\hline & $\mathrm{m} \mathrm{m} / \mathrm{y}$ & $\mathrm{mil} / \mathrm{y}$ \\
\hline $\begin{array}{l}2.25 \mathrm{Cr}-1 \mathrm{Mo} \\
5 \mathrm{Cr}-1 \mathrm{Mo} \\
\text { Modified } 9 \mathrm{Cr}-1 \mathrm{Mo}\end{array}$ & $\begin{array}{l}2.305 \\
2.652 \\
2.132\end{array}$ & $\begin{array}{r}90.7 \\
104.0 \\
83.9\end{array}$ \\
\hline $\begin{array}{l}7 \mathrm{Cr}-1 \mathrm{Mo} \\
\text { Type } 410 \text { Stainless Steel } \\
\text { Type } 321 \text { Stainless Steel }\end{array}$ & $\begin{array}{l}1.875 \\
0.422 \\
0.446\end{array}$ & $\begin{array}{l}73.8 \\
16.6 \\
17.5\end{array}$ \\
\hline $\begin{array}{l}\text { Carbon Steel } \\
\text { Type } 304 \mathrm{~L} \text { Stainless Steel } \\
\text { Type } 310 \text { Stainless Steel }\end{array}$ & $\begin{array}{l}0.827 \\
0.517 \\
0.100\end{array}$ & $\begin{array}{r}32.5 \\
20.3 \\
4.0\end{array}$ \\
\hline $\begin{array}{l}\text { Type } 316 \mathrm{~L} \text { Stainless Steel } \\
\text { Type } 317 \text { Stainless Steel } \\
\text { Ferralium }\end{array}$ & $\begin{array}{r}0.250 \\
<0.003 \\
0.059\end{array}$ & $\begin{array}{r}9.9 \\
<0.1 \\
2.4\end{array}$ \\
\hline $\begin{array}{l}\text { Type } 317 \mathrm{LM} \text { Stainless Steel } \\
\text { Carpenter } 20 \mathrm{Cb} 3 \\
\text { Incoloy } 825\end{array}$ & $\begin{array}{l}<0.003 \\
<0.003 \\
<0.003\end{array}$ & $\begin{array}{l}<0.1 \\
<0.1 \\
<0.1\end{array}$ \\
\hline
\end{tabular}


Table 2.15. Calculated corrosion rates for coupons exposed 576 hours at the manway located at tray 80 in the phenol distillation tower of the Dakota Gasification Company's Beulah, North Dakota plant.

\begin{tabular}{lcc}
\hline & \multicolumn{2}{c}{ Corrosion } \\
Material & Rate \\
\cline { 2 - 3 } & $\mathrm{m} \mathrm{m} / \mathrm{y}$ & $\mathrm{mil} / \mathrm{y}$ \\
\hline 5 Cr-1Mo & 1.263 & 49.7 \\
Modified 9Cr-1Mo & 1.361 & 53.5 \\
7Cr-1Mo & 1.339 & 52.7 \\
Type 410 Stainless Steel & 0.980 & 38.6 \\
Type 321 Stainless Steel & 0.298 & 11.7 \\
Carbon Steel & 0.546 & 21.4 \\
Type 304L Stainless Steel & 0.197 & 7.8 \\
Type 310 Stainless Steel & 0.051 & 2.0 \\
Type 316L Stainless Steel & 0.041 & 1.6 \\
Type 317 Stainless Steel & 0.003 & 0.1 \\
Ferralium & 0.004 & 0.2 \\
Type 317LM Stainless Steel & $<0.003$ & $<.1$ \\
Carpenter 20Cb3 & $<0.003$ & $<0.1$ \\
\hline
\end{tabular}




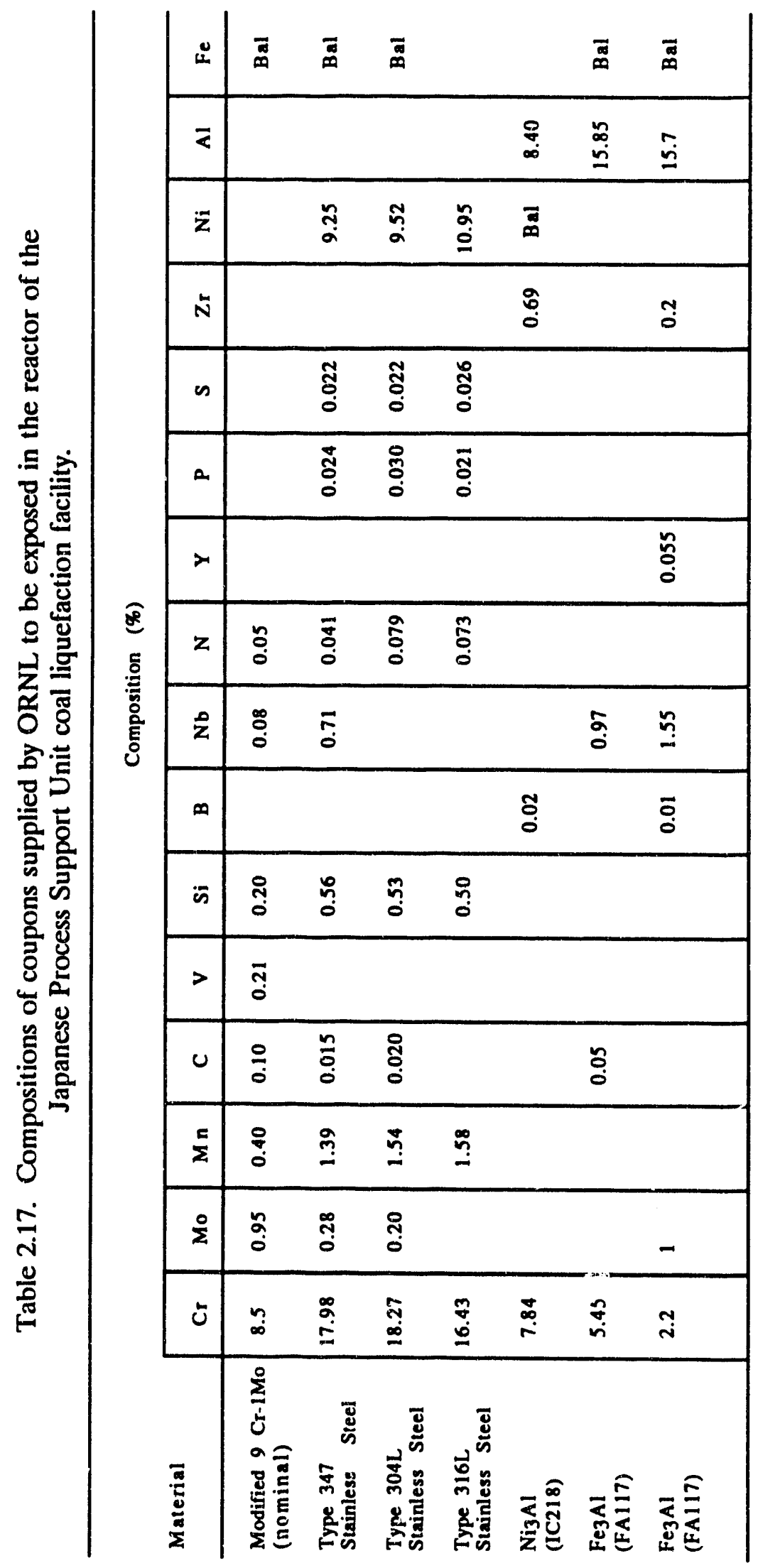




\title{
3. ENVIRONMENTAL ANALYSIS SUPPORT
}

\author{
C. R. Boston
}

\subsection{ENVIRONMENTAL SUPPORT TO THE CLEAN COAL PROGRAM - R. L. Miller}

Work during this six-month period focused on the preparation for DOE's Pittsburgh Energy Technology Center (PETC) of a preliminary draft Environmental Impact Statement (EIS) for the Healy Clean Coal Project (HCCP). The project, proposed by the Alaska Industrial Development and Export Authority and selected by DOE in the third solicitation of the Clean Coal Program, would be located in Healy, Alaska, about 4 miles north of the nearest border of Denali National Park and Preserve (DNPP). The proposed project is a new 50 megawatt coal-fired power generating facility that would be collocated with an existing 25 megawatt conventional pulverized-coal unit owned and operated by Golden Valley Electric Association. The new facility would feature integration of advanced combustion and flue gas cleanup technologies to reduce emissions of $\mathrm{SO}_{2}$ and $\mathrm{NO}_{x}$ The EIS is notable because it is the first site-specific EIS prepared for the Clean Coal Program.

Impacts to air quality, surface water, groundwater, and ecological and socioeconomic resources from construction and operation of the HCCP were evaluated and preliminary results indicate that, for most resource areas, the impacts are not expected to be significant. Tentative findings for areas of potential concern are summarized below. Of primary concern, as predicted by analyses based on computer models, is the degradation of air quality and visibility expected in portions of DNPP because of HCCP operation. Also, during the winter, the length of ice-free water in the Nenana River downstream of the HCCP is expected to increase because of the HCCP's thermal discharge of once-through cooling water.

Consequently, ice bridge formation on the river at the village of Ferry, located about 10 miles downstream, may be affected (the ice bridge is used by residents to transport supplies across the river during winter). Finally, moderate socioeconomic impacts are expected during construction and operation of the HCCP, particularly in the areas of housing, education, traffic, police and fire protection, and medical services.

Additional activities included reviews of Environmental Information Volumes and Environmental Monitoring Plans prepared by the project participants for Clean Coal projects. The final Environmental Information Volumes are used by ORNL as a resource in preparing 
environmental documentation such as EISs or Environmental Assessments (EAs) for the projects.

At DOE's urgent request, ORNL provided a senior environmental analyst to serve in Washington D.C., for five weeks as a member of DOE's Environmental Review Panel/Clean Coal Technology IV Source Evaluation Board (SEB). The panel assessed the adequacy of proposed approaches for meeting requirements and minimizing impacts in the areas of environment health and safety. Of the 33 proposals located in 17 states that were evaluated, 9 were selected for funding. The combined Government industry value of all Clean Coal projerts is more than $\$ 6.5$ billion with about $\$ 2.3$ billion in Federal funds. Round four represents about $\$ 570$ million of the total Federal funding.

\subsection{ENVIRONMENTAL SUPPORT TO METC R\&D PROJECTS - R. L. Miller}

Substantial work on first project began in October 1991; no substantial progress during reporting period.

\subsection{OIL RESEARCH PROGRAM ENVIRONMENTAL SUPPORT - R. I. Miller}

Substantial work on programmatic environmental assessment began in November 1991; no substantial progress during reporting period.

\subsection{ENVIRONMENTAL TRENDS ANALYSIS - R. J. Olson}

The National Environmental Policy Act of 1969 (NEPA) requires the President's Council of Environmental Quality (CEQ) to report on the status and condition of the environment; current and foreseeable trends in the quality, management, and use of the environment; and the effects of environmental trends. To date, CEQ has had limited success in bringing together data, expertise, and analysis resources. With renewed recognition of the necersity anú complexity of this task, CEQ is readdressing its environmental trends assessment activities.

The Department of Energy supported this task by providing an ORNL staff person for a 6-month assignment to work with the CEQ staff. R. J. Olson, Environmental Sciences Division, provided technical expertise to the CEQ staff, initiated interagency meetings, reviewed past environmental trends products, evaluated current needs, and developed a plan for future CEQ efforts. In the report, a trends assessment framework, analysis approaches, and research needs are discussed to provide the scientific basis for analyzing anci reporting trend data. Data issues that often emerge when diverse data need to be integrated are 
identified, and ways for achieving more effective communication are described. Finally, recommendations are given for $\mathrm{CEQ}$ to formalize and strengthen an interagency program to carry out this mission on a continuing basis. 


\title{
4. COAL CONVERSION DEVELOPMENT
}

\author{
C. D. Scott
}

Coal conversion research has continued on the biological solubilization of coal. A promising technique for enhancing the solubility of enzymes in organic media is being tested. Activities are also continuing $\mathrm{Ol}_{2}$ the study of mild gasification of coal.

\subsection{BIOPROCESSING RESEARCH - C. D. Scott, B. D. Faison, and T. C. Scott}

This program has examined the feasibility of using biological catalysts for the conversion of coal to useful liquid fuels and the biological enhancement of coal derived liquids. Biological reagents potentially useful in this application include intact microorganisms in pure or mixed culture and isolated enzymes. These biocatalysts are employed in aqueous or organic media to enhance coal liquefaction on enhancement of coal-derived liquids.

Two approaches to biological processing are being considered, namely (1) direct anaerobic enzymatic solution or liquefaction; and (2) the demonstration of microbial heteroatom removal from coal-derived materials. The primary emphasis during this period has been on the investigation of the use of chemical modification of enzymes in organic media to enhance solubilization of coal.

\subsubsection{Enzymatic Liquefaction of Coal}

Research has continued on the use of reducing enzymes in vitro for the enhanced solubilization/liquefaction of coal. Chemical modification of the enzymes allows their use in an organic solvent.

\subsubsection{Chemical Modification of Enzymes}

Most aqueous-soluble enzymes such as the purified hydrogenase and cytochrome $\mathrm{C}$ used in this study have unmeasurable solubilization in nonpolar organic solvents such as benzene. However, it has been previously shown that such enzymes can be chemically modified to increase the hydrophobicity and thus increase the solubilization in organics.

During this period, the use of the reagent dinitrofluorobenzene (DNFB) to chemically modify enzymes was investigated further. This approach introduces large numbers of dinitrophenyl (DNP) groups into the structure of the protein making it much more hydrophobic and, thus, more soluble in organic solvents. A series of tests were made on optimizing the chemical and physical steps used for the phenylization of enzymes by DNFB. 
As a result, the chemical procedure has been modified to include some additional steps. Typically 10 - to $100-\mathrm{mg} / \mathrm{mL}$ of the enzyme was dissolved in water and $0.1 \mathrm{~g} \mathrm{NaHCO}_{3} / \mathrm{mL}$ was added to the mixture. Then, twice as much ethanol containing $0.05 \mathrm{~mL} \mathrm{DNFB} / \mathrm{mL}$ ethanol was added to the mixture. After stirring for two hours at ambient temperature, there was a yellow precipitate and supernatant. The precipitate was, presumedly, the phenylized protein and excess bicarbonate while the solution contained excess DNFB and partially modified enzyme. This slurry was dialyzed against $67 \%$ ethanol for 24 hours using a membrane that had a nominal exclusion limit of 12,000 Daltons. After dialysis, $10 \mathrm{mg} / \mathrm{mL}$ of sodi- hionate was added and the slurry was lyophized and then contacted for $1 \mathrm{~h}$ with th. urgauic solvent of interest where a portion of the modified enzyme was solubilized. The dialysis tended to remove unreacted DNFB and sodium bicarbonate, while the addition of dithionite maintained the enzy mes in a reduced state.

\subsubsection{Degradation of Model Compounds}

Two model compounds [1,2,-bis(4-pyridyl) ethane (PE) and 1,2-bis(4-quinolyl) ethane $(\mathrm{QE})]$ that have chemical structures somewhat similar to that of a portion of coal are being used to more clearly define enzyme interactions in benzene. Additional tes's were made with DNP-enzymes ciissolved in benzene as biocatalysts for the degradation of the model compounds. Both hydrogenase-DNP and cytochrome C-DNP were tested using the optimum techniques developed for the chemical modification of the $\_$nzyme. Each of the individual modified enzymes were first tested and then a combination of the two was used. The tests were made with a benzene mixture containing $1 \mathrm{mg} / \mathrm{mL}$ of the model compounds at $30^{\circ} \mathrm{C}$ for $24 \mathrm{~h}$. With QE, there was a definite enhancement of degradation of the model compound when the enzymes were present with the maximum effect occurring when both proteins were present (Fig. 4.1). Greater than 50\% of the QE disappeared during the first $12 \mathrm{~h}$, with essentially no additional reaction occurring during the last $12 \mathrm{~h}$ of the $24-\mathrm{h}$ test. Although there is indication of a small amount of the expected breakdown products, the major products have not yet been identified. This may indicate a more significani degradation than a simple cleavage at or in the ethane bridge.

Similar tests were also carried out with degradation of PE. The most significant results again were with mixed enzymes; however, the apparent degree of interaction was only about $20 \%$ (Fig. 4.2). As with the ter: with QE, there were minimal amounts of the expected breakdown products, perhaps indicating a more significant alteration of the model compound. 


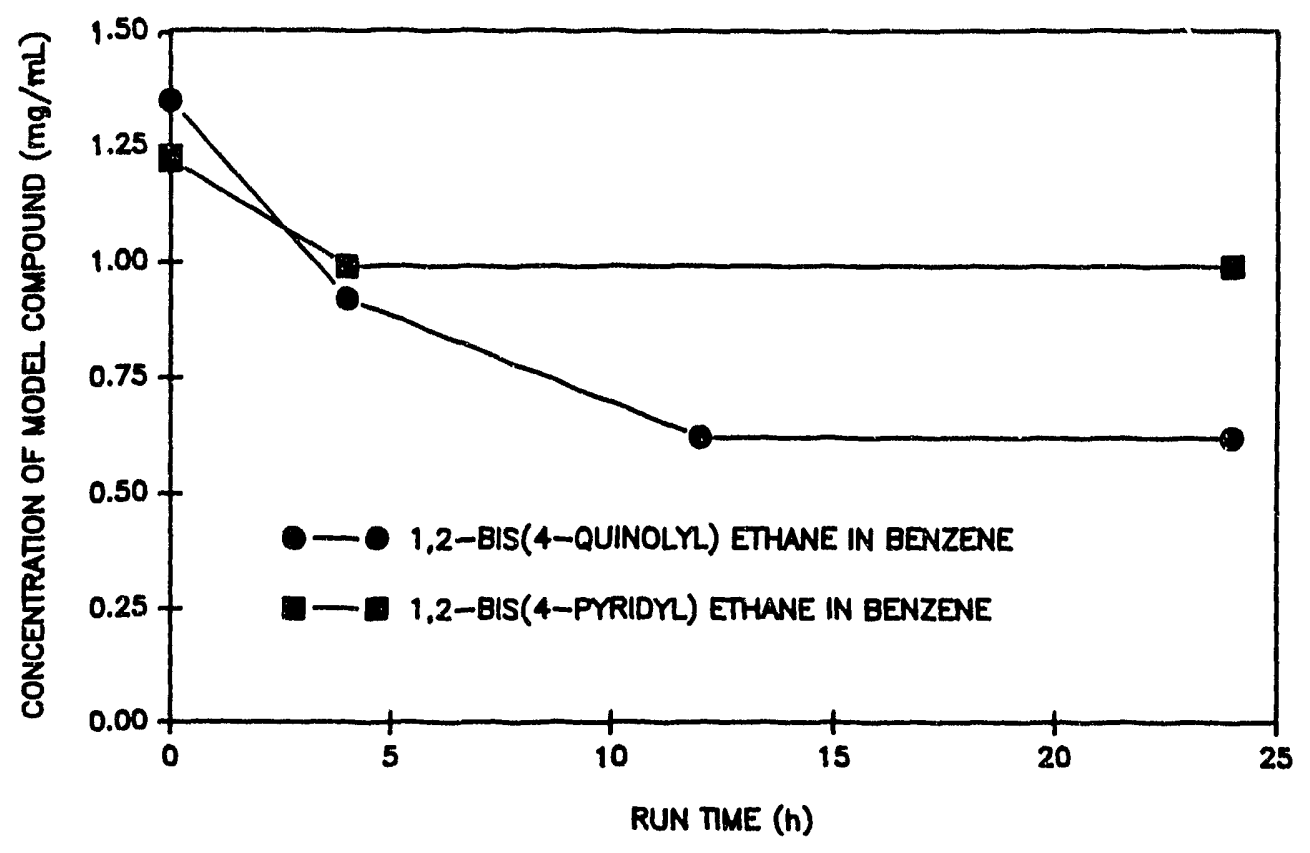

Fig. 4.1. Decrease in the concentration of model compounds in benzene at $30^{\circ} \mathrm{C}$ under a hydrogen atmosphere in the presence of both DNB-hydrogenase and DNB-cytochrome C.

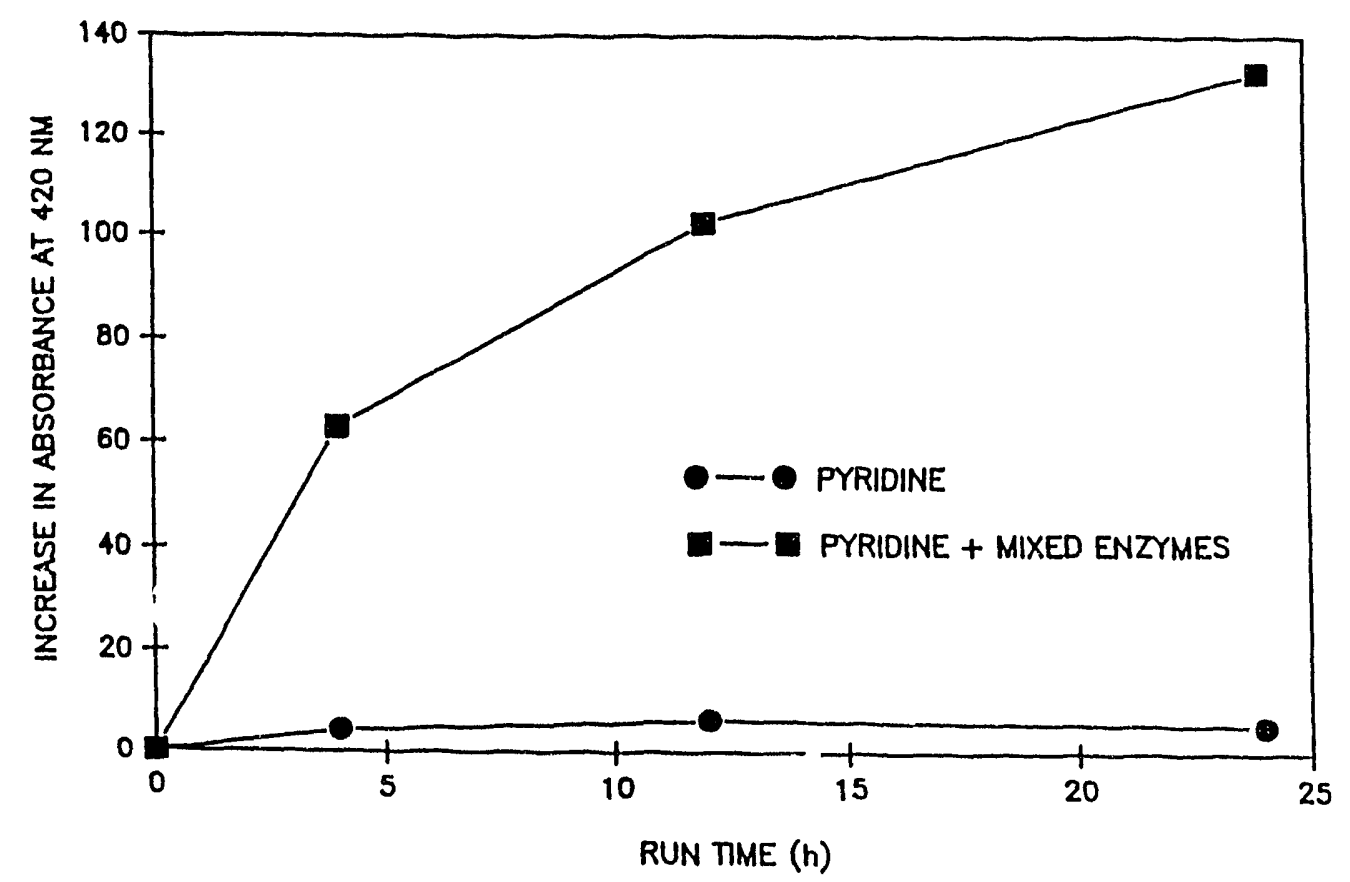

Fig. 4.2. Enhancement of the solubilization of Illinois No. 6 coal by the addition of DNP-hydrogenase and DNP-cytochrome $\mathrm{C}$ to pyridine at $30^{\circ} \mathrm{C}$. 
Since there is no detectable loss of the model compounds under similar experimental conditions but in the absence of the biocatalysts, it can be assumed that the enhancement in the loss of the model compound is due to the catalytic action. However, it might be possible for some of the model compounds to be adsorbed or chemically attached to the enzymes and, thus, not be detected by the GC analysis since they would not be volatile. In order to rule out this mechanism, the same type of tests were made but the catalytic enzymes were replaced by the same quantity of bovine serum albumin (BSA), a noncatalytic protein obtained from Sigma Chemical Co. Since the enzymes are just specialized proteins with structures similar to BSA, this type of test should make it possible to observe possible adsorption or chemical attachment effect.

Approximately $0.2 \mathrm{~g} \mathrm{BSA}$ was modified with DNFB for $2 \mathrm{~h}$ as described above. The solid material was washed in $\mathrm{H}_{2} \mathrm{O}$, ethanol, and ether, then freeze dried and contacted with benzene for $30 \mathrm{~min}$. A material balance showed that $1 \mathrm{mg} / \mathrm{mL}$ of the modified BSA went into solution in the benzene under a hydrogen atmosphere. As before, approximately $1 \mathrm{mg} / \mathrm{mL}$ of the $\mathrm{QE}$ was added to the benzene mixture and stirred at $30^{\circ} \mathrm{C}$ for $24 \mathrm{~h}$. Samples were taken at $0,4,10$, and $24 \mathrm{~h}$ for analysis on a Hewlett Packard $5890 \mathrm{GC}$, with the temperatures of the split injector and the flame ionization detector both set at $350^{\circ}$, and the oven temperature ranged from $250^{\circ}$ to $325^{\circ} \mathrm{C}\left(7^{\circ} \mathrm{C} / \mathrm{min}\right.$.). The retention time of quinolyl ethane was $32 \mathrm{rin}$.

There was less than a 6\% decrease in QE concentration during the $24 \mathrm{~h}$ period in the BSA solution compared to the greater than $50 \%$ decrease with the mixed enzyme solution. These results eliminate a possible physical or chemical interaction with protein as the explanation for the decrease of quinolyl ethane in the reaction mixture. Future experiments will further explore possible degradation products and the methods for measuring them.

\subsubsection{Coal Liquefaction/Solubilization of Coal}

In the recent past, the emphasis has been on the use of benzene as the reaction medium. During this time period, toluene and pyridine were also investigated. In the test with toluene, there was a modest enhancement of $c$ :al liquefaction/solubilization but only one third of the effect seen with benzene. On the other hand, there was a significant enhancement of coal liquefaction/solubilization when pyridine was used. In this case, the interaction with : sal was observed throughout the $24-\mathrm{h}$ period but the rate was steadily decreasing. Although it is difficult to achieve a good material balance based on the weight of the solids residue, there was greater than 5\% liquefaction/solubilization in the presence of the 
enzymes and less than $1 \%$ loss of coal in the absence of the enzymes. Material balance iests, based on the high-boiling-point fraction in the product, indicated a much greater degree of coal interaction.

The most exciting results during this quarter was from a test in a small fluidized-bed bioreactor in which $35 \mathrm{~mL}$ of pyridine containing approximately $2 \mathrm{mg} / \mathrm{mL}$ each of the two modified enzymes contacted about $0.5 \mathrm{~g}$ of -325 mesh Illinois No. 6 coal for $24 \mathrm{~h}$ at $30^{\circ} \mathrm{C}$ with hydrogen sparging. Based on absorbance measurements at $350 \mathrm{~nm}$, all of the coal liquefaction occurred during the first $4 \mathrm{~h}$ (Table 4.1). Material balances measurements, based on the weight of dry coal before and after the test, indicated that approximately $7.4 \%$ of the coal was solubilized in pyridine alone while $14.6 \%$ was liquefied/solubilized when the enzymes were present, an increase of almost $100 \%$. Apparently the additional shear force in the fluidized bed coupled with direct hydrogen sparging of the reaction mixture contributed to an even greater amount of coal interaction.

Table 4.1. Increase in absorbance at $350 \mathrm{~nm}$ of the reaction mixture in a fluidized-bed bioreactor with hydrogen sparging containing pyridine with DNP-hydrogenase and DNP-cytochrome C in contact with -325 mesh Illinois No. 6 Coal

\begin{tabular}{cc}
\hline Time $(\mathrm{h})$ & $\begin{array}{c}\text { Increase in absorbance } \\
\text { (20:1 dilution) }\end{array}$ \\
\hline 4 & .64 \\
10 & .59 \\
24 & .60 \\
\hline
\end{tabular}

\subsubsection{Possible Processing System}

Although this processing concept has not been developed to the point where the parameters for process scale-up are available, it is interesting to consider what a simplified process flowsheet would look like. Quite likely, the primary bioconversion system would be a fluidized-bed bioreactor with continuous coal and solvent feed and recycle of the enzyme biocatalyst and hydrogen (Fig. 4.3). If possible, a provess-derived light solvent would be used as the working fluid and the solid waste would be ash. As additional information is generated, the process flowsheet can be more completely defined. 
ORNL DWG. 89A-826

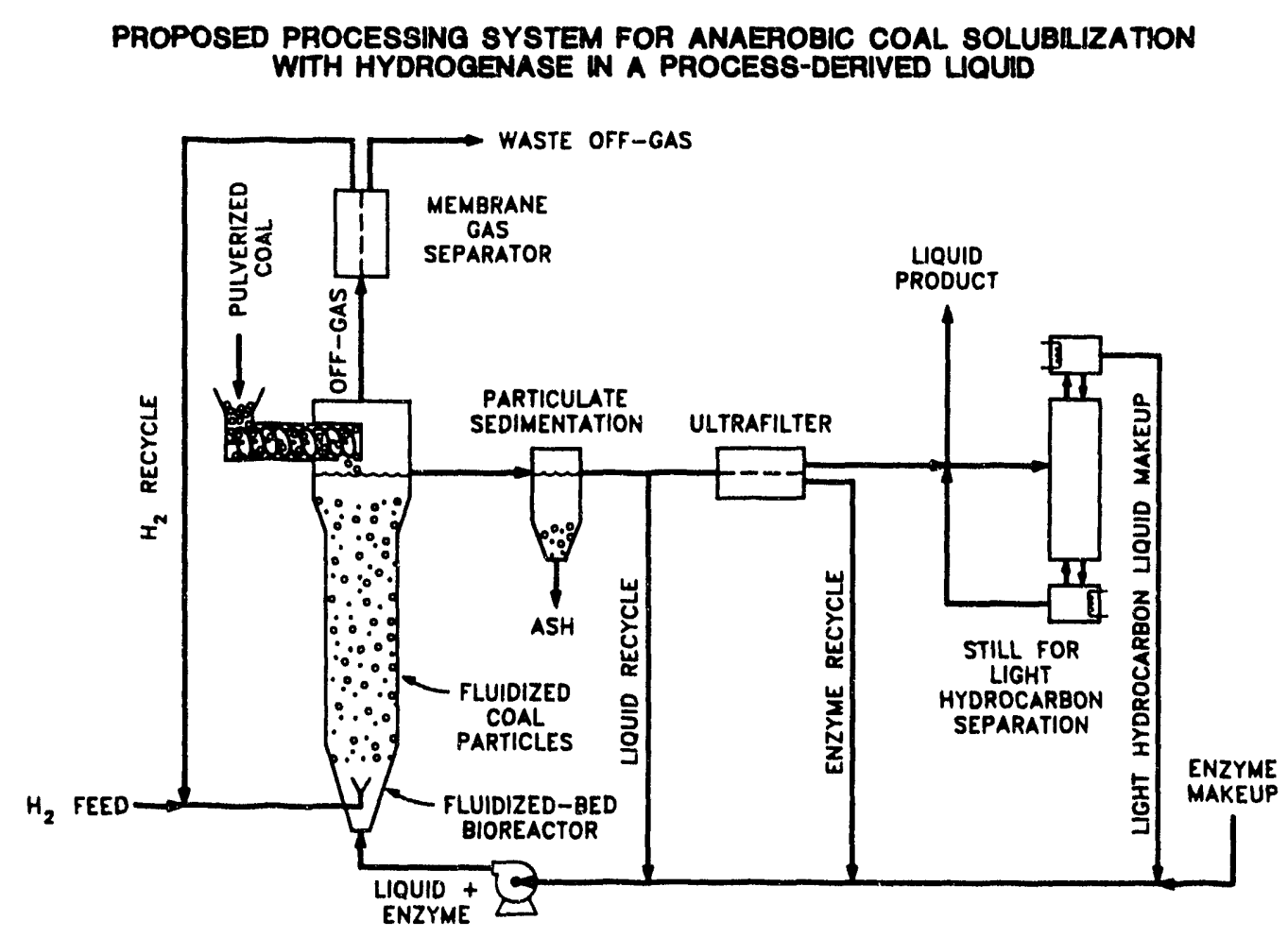

Fig. 4.3. Simplified flowsheet for the enzyme-enhanced liquefaction of coal in a process-derived solvent utilizing molecular hydrogen.

\subsubsection{Microbial Heteroatom Removal from Coal-Derived Materials}

This research explores the feasibility for microbial removal of sulfur, nitrogen, and/or oxygen from constituents of coal-derived liquids, tars, and process wastewaters. Paecilomyces $s p$. TLi, a coal-solubilizing fungus, was previously shown to effect a sulfur-specific attack on aromatic sulfides, disulfides, and sulfur-containing heterocycles structurally related to compounds contained in ccal conversion products. Although the organism grew aerobically and the attack on sulfur was oxidative (in some cases achieving sulfur removal as sulfate), oxygen was not necessarily incorporated into the products formed. The goal of the current work is to establish conditions for microbial desulfurization of coal-related compounds, with formation of nonoxygenated products exclusively.

Studies with Paecilomyces have continued, with attention to the development of new, quantitative analytical methods for detection of minor (nonoxygenated) organic products. A parallel effort has focused on the identification of new organisms that will produce reduced products exclusively. 
Environmental sampling has been carried out with the goal of obtaining organisms capable of the anaerobic desulfurization of coal-derived materials. Emphasis has been placed on the removal of sulfur from heterocyclic compounds, specifically polycyclic thiophene derivatives of the type known to be present within tars. A variety of microorganisms are known to metabolize reduced inorganic sulfur compounds anaerobically, with production of elemental sulfur or sulfate. The anaerobic fate of sulfur heterocycles has not previously been studied.

A variety of environmental matrices has now been sampled. Microbial consortia capable of energy-yielding metabolism at the expense of reduced sulfur have been obtained. Most of these consortia contain photosynthetic organisms, i.e., the purple or green photosynthetic bacteria. Organisms of this type oxidize sulfide, elemental sulfur, thiosulfate, or sulfite to sulfate. This metabolic versatility suggests that they may also attack sulfur contained within organic compounds. The biochemistry of sulfur oxidation in these organisms is not well understood. It is, however, clear that a judicious choice of organisms will allow selection of those incapable of the complete degradation of organic carbon compounds. In the latter case, sulfur may be removed preferentially without effect on the aromatic moieties, and with release of soluble sulfate. This process would be analogous to that demonstrated in cultures of Paecilomyces, with the exception that there would be no possibility of the introduction of molecular oxygen into the organic structure. Indeed, certain purple photosynthetic bacteria are known to introduce hydrogen into aromatic compounds such as benzoate. (This was the basis for interest in these organisms for coal conversion per sf.) Tests have been initiated to determine whether these cultures are able to attack organic sulfur compounds, specifically dibenzothiophene.

\subsection{MILD GASIFICATION PRODUCT CHARACTERIZATION - R. L. Graves}

\subsection{Background}

From previous studies it is known that mild gasificatiun of coal produces liquids that are potentially useable as diesel fuel or diesel fuel diluents ${ }^{1,2}$. However, the yield and quality of these liquids as well as the degree of upgrading required can vary substantially with the process severity (i.e., the degree of devolatilization). Char is similar in that the degree of devolatilization directly affects its combustion properties. The economic viability of any mild-gasification process is thus determined by tradeoffs among product yield, upgrading costs, and end-use requirements. 


\subsection{Project Description}

The purpose of this investigation is to develop basic characterization data for the liquid and char products of mild gasification. Such data are needed to evaluate key relatior hips among process conditions, product yield, and product end-use value. Of particular interest is the suitability of the liquid (with minimal upgrading) as diesel fuel and the suitability of the char as boiler fuel, although non-fuel uses of these products are also considered.

Representative samples of mild-gasification liquids and chars are being obtained from industrial groups involved in the development of candidate processes. These samples are subjected to a variety of characterization tests including:

- chemical and physical analyses of the char and liquids;

- combustion testing of the liquids in a diesel engine; and

- combustion testing of the chars in laboratory reactors.

In general, ORNL is tasked to carry out the more detailed, unconventional laboratory characterizations such as proton NMR (nuclear magnetic resonance), FTIR (Fourier transform infrared) spectroscopy, and neutron activation. Standard laboratory assays are carried out either by ORNL or major mild gasification teams. The use of the liquids as engine fuels, with either blending or mild upgrading, is still of interest so those evaluations have been continued. Although there are several high-value products that can be derived from the char, its use as fuel remains a potentially large market. In addition, it is anticipated that char combustion will supply a major fraction of process heat in commercial mild-gasification processes. Hence a basic understanding of the char combustion properties is important.

\subsubsection{Project Status}

During this reporting period, a paper was written for the Eleventh METC Gasification and Gas Stream Cleanup Contractors Review Meeting. The reader is referred to that publication for complete details and data. Work prior to 1991 can be found in references 3-6.

\subsubsection{Char and Reference Fuel Samples}

Char samples have been obtained for candidate mild gasification (MG) processes developed by four groups: (1) Coal Technology Corporation (CTC, formerly part of United Coal Company); (2) SGI International (SGI); (3) Western Research Institute/AMAX Coal (WRIA); and (4) IGT/Peabody Coal (IGTP). Groups 1, 3, and 4 are sponsored in part by 
DOE METC, while group 2 has been a private venture. The CTC and SGI chars were studied in 1989, and reported on in 1989 and $1990 .^{3,6}$

Four well-inown reference fuels were included in the char combustion testing to provide a broader basis for comparison. These fuels were Texas lignite, Kentucky No. 9 coal (high-volatile, swelling bituminous), delayed petroleum coke, and anthracite coal. Combustion reactivities as determined by thermogravimetric analysis (TGA) were determined for the chars and reference fuels in FY 1990 and were reported last year. ${ }^{6}$

Table 4.2 summarizes the proximate and ultimate analyses of the char samples, parent coals, and reference fuels. BET surface areas are also given for the chars. Note the extremely high surface area for the WRIA 2 char.

Table 4.2. Ultimate and proximate analyses of the test chars, parent coals, and reference fuels

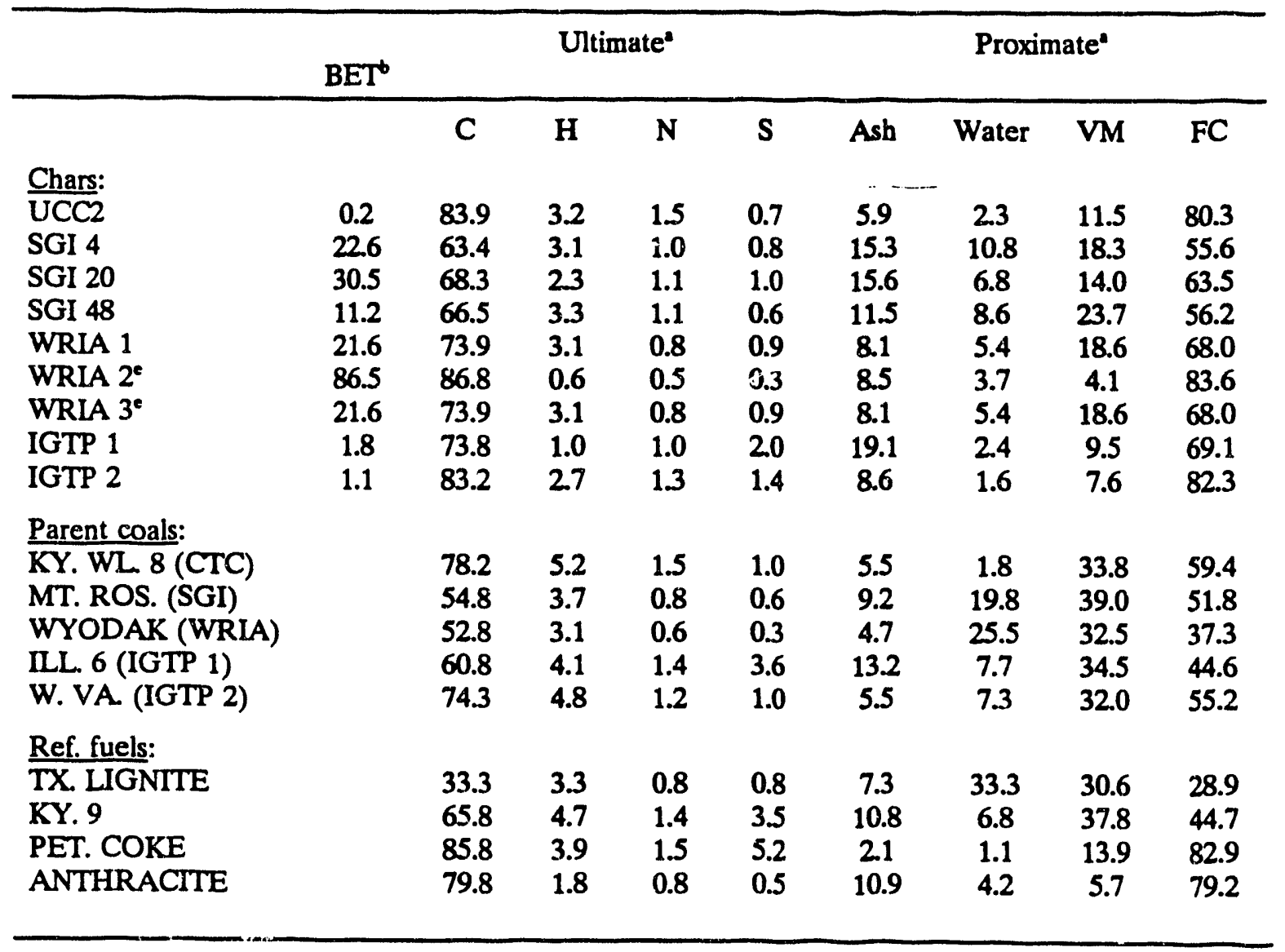

Analyses as weight percent on an as-received basis (i.e., ash and moisture included), $\mathrm{H}$ and $\mathrm{O}$ included moisture.

'BET surface area by $\mathrm{N}_{2}$ absorption $\left(\mathrm{m}^{2} / \mathrm{g}\right)$ for chiars only.

'Same process conditions as WRIA 1. 


\subsection{Fixed-Bed Reactor Tests}

High temperature combustion tests were conducted using a fixed-bed reactor at Babcock and Wilcox (B\&W) Alliance Research Center. This reactor was constructed for the Atmospheric Fluidized Bed Combustion Fuels Characterization Program sponsored by the Electric Power Research Institute (EPRI).

\subsubsection{Fixed-Bed Reactor Results}

Quantitative comparisons of the fixed-bed results can be made with various derived values such as: (1) burning rate at char ignition, (2) degree of fixed carbon conversion after a fixed elapsed time, and (3) time to achieve a given fixed-carbon conversion. Because the basic profiles following char ignition are all similar, any of these measures gives the same ranking. Table 4.3 compares relative Arrhenius rate parameters derived from the fixed-bed and TGA data. Note that while the WRIA 2 char burned readily in the fixed-bed reactor, it burned very slowly in the TGA $^{6}$ It is likely that this atypical behavior for WRIA 2 results from the extensive post-treatment it has received. We hypothesize that the extremely high surface area may tend to be passivated by adsorbed $\mathrm{O}_{2}$ at the low heating rate and low temperature of the TGA. Conversely, the higher heating rate and temperature of the fixed-bed reactor prevents or overcomes the passivation. Since the fixed-bed and TGA data are so different, the Arrhenius parameters shown in Table 4.3 for WRIA 2 are based only on the fixed-bed results.

Table 4.3. Arrhenius char combustion parameters derived from the combined combustion data

\begin{tabular}{|c|c|c|c|}
\hline Fued & $A^{*}$ & $\mathbf{E}$ & $r^{2}$ \\
\hline $\begin{array}{l}\text { Nen Dat } \\
\text { WRIA 1 } \\
\text { WRIA 2 } \\
\text { WRIA 3 } \\
\text { IGTP } 1 \\
\text { IGTP } 2\end{array}$ & $\begin{array}{l}1.4 \times 10^{5} \\
4.0 \times 10^{3} \\
4.5 \times 10^{4} \\
4.3 \times 10^{4} \\
25 \times 10^{4}\end{array}$ & $\begin{array}{l}114 \pm 21 \\
8.29 \pm 37 \\
107 \pm 33 \\
118 \pm 32 \\
124 \pm 21\end{array}$ & $\begin{array}{l}0.984 \\
0.953 \\
0.954 \\
0.964 \\
0.985\end{array}$ \\
\hline $\begin{array}{l}\text { Prov. Reparted } \\
\text { UCCI } \\
\text { SGI } 4 \\
\text { SGI } 20 \\
\text { SGI } 48\end{array}$ & $\begin{array}{l}1.7 \times 10^{4} \\
1.7 \times 10^{5} \\
3.0 \times 10^{4} \\
4.9 \times 10^{4}\end{array}$ & $\begin{array}{l}100 \pm 10 \\
117 \neq 10 \\
123 \pm 15 \\
98.3 \pm 9.3\end{array}$ & $\begin{array}{l}0.990 \\
0.997 \\
0.994 \\
0.997\end{array}$ \\
\hline $\begin{array}{l}\text { Ref. Fuets } \\
\text { TX LIGNITE } \\
\text { KENTUCKY } 9 \\
\text { PET. COKE } \\
\text { ANTHRACIIE }\end{array}$ & $\begin{array}{l}1.8 \times 10^{5} \\
1.6 \times 10^{6} \\
2.0 \times 10^{6} \\
2.8 \times 10^{4}\end{array}$ & $\begin{array}{c}94.3 \pm 5.4 \\
124 \neq 16 \\
100 \pm 9.6 \\
113 \pm 20\end{array}$ & $\begin{array}{l}0.999 \\
0.996 \\
0.990 \\
0.974\end{array}$ \\
\hline $\begin{array}{l}A=\text { Arrhenius } \\
\mathbf{E}=\text { Arrbenius } \\
\text { Assumes } 0.5 \text { or } \\
\text { Uncertainty lim } \\
\text { Based only on } \\
\text { 'Essentially sam }\end{array}$ & $\begin{array}{l}\text { al facto } \\
\text { rey (kJh } \\
\% \text { confix }\end{array}$ & & \\
\hline
\end{tabular}




\subsection{Char Evaluation Conclusions}

The above results suggest that the IGTP 2 char is more suitable for nonsensitive combustors, such as fluidized beds, stokers, or U-flame boilers, as is the UCC2. ${ }^{6}$ Based on last year's TGA data, the WRIA 2 char was also assumed to he a less reactive fuel, however the fixed bed data have shown that at higher temperatures with a higher heating rate, the behavior changes and the char burns like a more reactive fuel. In fluidized beds with underbed feed, the less reactive fuels may actually have some advantages over more reactive fuels because their performance should be less sensitive to feedpoint spacing. More freeboard combustion is likely to occur, however. Like the SGI chars, the WRIA 1, WRIA 3, and IGTP 1 chars appear to be sufficiently reactive for firing in a wide variety of combustors, possibly including those burning pulverized fuel.

\subsubsection{Liquid Product Characterization}

Liquid samples were received this year from Western Research Institute (WRI), the University of North Dakota Energy and Environmental Research Center (UNDEERC), and Coal Technology Corporation (CTC). The WRI liquids were received in two temperature cuts, IBP-215 ${ }^{\circ} \mathrm{C}\left(419^{\circ} \mathrm{F}\right)$ and $216-382^{\circ} \mathrm{C}\left(420-720^{\circ} \mathrm{F}\right)$. As past experience has demonstrated that raw coal liquids have poor ignition quality, a small quantity of the WRI $216-382^{\circ} \mathrm{C}$ cut was washed with the traditional $10 \mathrm{~N} \mathrm{NaOH}$. The difficulties inherent in phase separation encouraged the development of a bench method more closely mirroring industrial practice. Essentially, the WRI $216-382^{\circ} \mathrm{C}$ cut was blended with an equal volume of pentane and then extracted with $1 \mathrm{~N} \mathrm{NaOH}$ and washed twice with water. The pentane was then removed by rotary evaporation. The aqueous phenolic phase was acidified with $\mathrm{H}_{2} \mathrm{SO}_{4}$ and extracted with toluene to recover mixed aromatics. The mixed aromatics will later be converted to derivatives (derivatized) to produce materials likely to blend with the caustic-washed diesel fuel fraction. Because of its high water-solubles content, the lower temperature WRI cut (IBP-215 $\mathrm{C}$ ) was used in an as-received condition. The caustic washed WRI cut, like the similarly prepared CTC midwash sample, yielded encouraging engine test results which will be discussed subsequently. Table 4.4 summarizes results of analyses of the liquid samples. Note the differences for the raw and caustic washed WRI liquid. The CTC midwash coal liquid is a coalite distillate which is also caustic washed. Coalite liquid is produced from a low temperature gasification process. The details of the caustic washing process were not available to ORNL. The UNDEERC sample is composed of coal liquids from the sieve tower, but also 
contained substantial but indeterminate amounts of diesel fuel and decant oil, which were used as start-up fluids. Because of this contamination no diesel engine testing was conducted.

Table 4.4. Analysis of liquid fractions

\begin{tabular}{|c|c|c|c|c|c|c|}
\hline \multirow{3}{*}{ Conetituent } & \multicolumn{6}{|c|}{ Weight Percent } \\
\hline & \multirow{2}{*}{$\begin{array}{c}\text { WRI IBP-215 C } \\
\text { Raw }\end{array}$} & \multicolumn{4}{|c|}{ WRI 216-380'C } & \multirow{2}{*}{$\begin{array}{r}\text { Phillips } \\
\text { Na } 2 \\
\text { Diesel } \\
\text { Fuel }\end{array}$} \\
\hline & & Raw & $\begin{array}{l}\text { Caustic } \\
\text { Washed }\end{array}$ & $\begin{array}{l}\text { UNDERRC } \\
\text { (a rectived) }\end{array}$ & $\begin{array}{c}\text { CIC } \\
\text { midwash }\end{array}$ & \\
\hline Carbon & 77.43 & 80.83 & 84.85 & 86.71 & 86.25 & 86.49 \\
\hline Hydrogen & 8.34 & 8.88 & 9.75 & 10.87 & 10.10 & 12.81 \\
\hline Nitrogen & 0.51 & 0.58 & 0.60 & $<0.5$ & 1.08 & 0.01 \\
\hline Sulfur & 0.45 & 0.41 & 0.53 & 1.06 & 0.67 & 0.34 \\
\hline$H / C^{\circ}$ & 1.29 & 1.32 & 1.38 & 1.50 & 1.41 & 1.78 \\
\hline $\mathrm{H}_{2} \mathrm{O}$ & 3.22 & 0.47 & 0.14 & 0.48 & 0.05 & nil \\
\hline Aliphatic & 51.5 & 68.2 & 760 & 60.8 & 84.9 & 76.8 \\
\hline Aromatic & 48.5 & 31.8 & 24.0 & 39.2 & 15.1 & 9.6 \\
\hline Aliphatic/ & 1.06 & 2.14 & 3.17 & 1.55 & 5.62 & 8.00 \\
\hline
\end{tabular}

Mole basis.

Via proton NMR.

\subsubsection{Liquid Product Diesel Ignition Quality}

Typical mild-gasification conditions yield, substantial fractions of liquids which distill with, and are projected to replace, standard middle distillates. This project has been concerned with assessing current mild gasification middle distillates, neat and in several different fuel blends, as fuels for diesel engines. Although optimizing a variety of fuel properties, e.g., viscosity, energy density, or reactivity, is important in developing a viable fuel, the first concern is estimation of ignition delay in normal combustion. Because of the growing concern about the ability of the ASTM test to adequately reflect ignition performance of alternative fuels in conventional engines, a Deutz F1L-511W single cylinder engine was used to measure the ignition delays of the test fuels.

Engine testing of the caustic washed fuels was encouraging. While past experience has shown that adding coal liquids to diesel fuel rapidly degrades the ignition quality, blends containing the caustic washed liquids could tolerate greater amounts of coal liquid. The CTC midwash blends readily with diesel fuel at all concentrations, and was blended with Phillips No. 2 diesel control fuel for this experiment (cetane number 45). The WRI liquids were not completely miscible with the Phillips, therefore small amounts of cosolvents were added, 
namely 8.9 wt. \% soy fatty acids, and $2.4 \%$ ethanolamine. Additives of this type have been found to enhance the blending of alcohols or other additives with diesel fuel. ${ }^{6,7}$ These additives were used in the stated concentrations in all of the WRI test fuels, except for the test of the washed WRI liquid in neat form, and the raw WRI $215.382^{\circ} \mathrm{C}$ blend. It is encouraging that the washed liquid will run unblended in the engine, performing similar to a diesel fuel with a cetane number on the order of 25-30.

\subsection{Future Work}

A continuation of char and liquid evaluations is expected since several of the major mild-gasification teams only recently became sufficiently operational to produce substantial quantities of product. Characterization of liquid fractions, including engine fuel suitability, will continue, with investigations on low-severity methods for ignition quality improvement. Derivatization of the aromatic material recovered from mild caustic extraction of the WRI $216-382^{\circ} \mathrm{C}$ distillation cut is planned. The ultimate aim is development of a method for recovering these materials as mild gasification diesel fuel additives or performance enhancers. Recovery of the aromatics removed by caustic washing, approximately half of the carbon in the middle distillation cut, could substantially improve process economics and energy balances. In general, ORNL expects to continue providing analytical and technical support to METC and the mild gasification teams as requested.

In FY 1992, new coproduct samples are expected from the SGI process. Eventually, larger scale char tests in pilot furnaces will be advisable to confirm its use as a suitable boiler fuel. In addition, attrition tests are planned for the chars and several reference fuels to evaluate their friability, since highly friable fuels have lower combustion efficiency and exhibit more freeboard combustion in fluidized bed boilers. High-value, non-fuel uses of the char will continue to receive attention as well. As a result of the char combustion work, partly carried out by B\&W, ORNL and B\&W are negotiating a Cooperative Research and Development Agreement (CRADA) on this subject.

\section{References}

1. R. L. Graves and E. C. Fox, "Diesel Fuels From Minimally Processed Coal Liquids -Exploratory Investigations," Proc.19th IECEC Meeting San Franc sco, August 1984.

2. H. Moore, "Fuel Oil for Heavy Oil Engines," The Trans. of the Fuel Conference, World Power Conference, Vol. III, Percy Lund, Humphries \& Co. Ltd., London 1928. 
3. R. L. Graves, et al., "Mild Gasification Product Characterization," Proc. 9th Gasification and Gas Stream Cleanup Systems Contractors Review Meeting, Vol. II, DOE/METC-89/61-7, Vol. 2, June 1989.

4. C. S. Daw, "Combustion Characteristics of Mild Gasification Chars," Presented at the American Chemical Society Meeting, Miami Beach, Florida, September 10-15, 1989.

5. J. E. Mrochek, et al., "Characterization and Upgrading of Coal Liquids Derived from Mild Gasification Processes," Presented at the American Chemical Society Meeting, Miami Beach, Florida, September 10-15, 1989.

6. C. S. Daw, et al., "Mild Gasification Product Characterization -- 1990 Results," pp. 509-518 in Proc. 10th Gasification and Gas Stream Cleanup Systems Contractors Review Meeting, Vol. II, DOE/METC-90/6115, Vol. 2, August 1990.

7. B. H. West, A. L. Compere, and W. L. Griffith, "High-Alcohol Microemulsion Fuel Performance in a Diesel Engine," Society of Automotive Engineers paper number 902101, October 1990. 


\title{
5. COAL COMBUSTION RESEARCH
}

\author{
R. L. Graves
}

\subsection{ANALYSIS OF FBC DETERMINISTIC CHAOS - C. S. Daw}

\subsubsection{Background}

Unique and innovative approaches are needed to optimize fossil energy conversion processes (such as fluidized bed combustion, coal gasification, hot-gas cleanup, oil-shale retorting, and catalytic cracking of petroleum) that employ fluidized beds for contacting streams of fluids and particulate solids. Of particular concern is the need to develop improved diagnostics for preventive maintenance, scale-up and engineering design procedures, and process control methods to maximize performance and minimize emissions.

Recent research in physics and mathematics suggests that much of conventional dynamical theory is inadequate to accurately describe the behavior of nonlinear deterministic systems. Further, analysis of many commonplace phenomena such as fluid turbulence and mechanical vibration suggests that nonlinear processes are the rule rather than the exception. The body of literature that has been developed to encompass this area of research typically refers to such behavior as "deterministic chaos" or just "chaos" for short. Considering the highly turbulent nature of fiuidized bed reactors, it is reasonable to expect that deterministic chaos is likely to be an important feature in their behavior. Preliminary analyses of fluidized bed pressure drop and voidage data from ORNL and METC support this expectation.

\subsubsection{Summary of Progress}

Activity on this project was initiated in this reporting period. The focus of this initial work has been primarily twofold: (1) analysis of experimental pressure and voidage measurements from laboratory fluidized beds to confirm the presence of deterministic chaos and its major features, and (2) development of a deterministic bubble growth mor'el that "explains" the occurrence and qualitative features of chaos in gas-fluidized beds. Both research areas have proven to be very productive.

\subsubsection{Analysis of Experimental Pressure and Voidage Signals}

Experimental gas-fluidized bed data were acquired using a 10.2-cm-diam. fluidized bed at ORNL and the University of Tennessee (UT) and 15.2-cm-diam. and 30.5-cm-diam. beds at METC. In all cases the beds were operating at atmospheric pressure and room temperature. 
A wide range of particle types were used including corn, nylon spheres, cracking catalyst, acrylic spheres, and stainless steel. Particle sizes varied from $5 \mathrm{~mm}$ to approximately 150 microns.

Experimental data consisted of time series measurements made at selected bed levels in each of the laboratory beds. Pressure measurements were collected at ORNL and UT, and both pressure and voidage measurements were collected at METC. Pressure measurements were made using commercial pressure transducers capable of millisecond responsc times. Voidage measurements were made using a specially acsigned, high-resolution capacitance imaging system developed at METC. ${ }^{1}$

Digital sampling rates for data collection varied between $\leqslant 0$ and 500 samples per second. It was determined by experimentation that a sampling rate of appr wximately 200 samples/s is optimum for visualization of gas-fluidized bed dynamics.

Beyond standard Fourier analysis, time series data were analyzed by remapping the data into a higher dimensional "phase space" according to the so-called "meti od of delays". 23 This procedure is based on a fundamental theorem of nonlinear dynamics some times referred to as the Mane-Takens embedding theorem. The result is a dynamical "state trajectory" or "phase portrait" which, according to theory, is a mathematically equivalent facsimile of the "true" state-space trajectory that one could construct if we had perfect knowledge of the governing differential equations.

Once the phase portraits were reconstructed for each time series, they were visualized by means of projections into two and three dimensional subspaces and by construction of Poincare sections. Quantitative "chaos" measures were generated by estimating principal eigenvalues, correlation dimension, Kolmogorov entropy, and, in some cases, Lyapunov spectra. ${ }^{3,4}$

The results of these analyses clearly indicate that gas- fluidized beds are dominated by deterministic chaos. Further, changes in the phase-space characteristics of time-series pressure-drop and voidage measurements directly reflect observable changes in the fluidization regime. This strongly suggests that phase-space "signatures" can be used as a basis for controlling fluidization. It is also clear that the phase-space signatures are much more discriminating between different fluidization states than Fourier analysis.

Most of the data exhibit correlation dimensions between 2 and 5 and Kolmogorov entropies between 2 and 15 bits/s. These values indicate that the level of complexity in 
fluidized beds is relatively typical compared with other physical systems studied so far and should be reasonably amenable to analysis using chaotic time series methods developed previously.

Typical results of pressure and voidage signal analyses are given in more detail in Reference 5.

\subsubsection{A Bubble Growth Model for Fluidized Bed Chaos}

In order to better interpret experimental data and understand how chaos might arise in fluidized beds, a bubble growth model was developed based on experimentally determined correlations for bubble velocity. The basic assumptions of the model are as follows:

- Bubbles are pictured as rising in single-column chains along the bed axis.

- Bubbles are assumed to be spherical up to diameters equal to $80 \%$ of the bed diameter.

- Bubbles larger than $80 \%$ of the bed diameter become cylindrical slugs with hemispherical end caps. The diameters of the cylindrical and hemispherical sections are $80 \%$ of the bed diameter.

- The rise velocity of bubbles is given by correlations developed from experimental measurements at METC. ${ }^{6}$

- When two bubbles touch, they begin to coalesce by constant shrinkage of the lower bubble and growth of the upper bubble (bubble gas volume is conserved). Coalescence continues until the lower bubble completely empties and the total number of bubbles reduces by 1 .

- Bubbles exit from the bed when their centers reach the top bed surface.

- Bubble formation at the bottom of the bed can be set at a constant rate or allowed to vary spontaneously by balancing bubble expansion with rise velocity.

Details of how the above assumptions are implemented in the model are given in Reference 7. The resultant form of the model consists of a series of $\mathrm{N}$ ordinary differential equations

$$
d Z(i) / d t=U(i)=f\left\{D_{b}(i), D_{b}(i-1), Z(i), Z(i-1)\right\}
$$

where $\mathrm{N}=$ the number of bubbles at time $\mathrm{t}$

$\mathrm{U}(\mathrm{i})=$ the bubble rise velocity (from experimental correlations)

$\mathrm{Z}(\mathrm{i})=$ the axial distance of bubble $\mathrm{i}$ above the distributor. 
The essential feature of the model that gives rise to the possibility of chaotic behavior is the significant nonlinearity of the function $\mathrm{f}$.

To produce model time series that would be analogous to the experimental measurements, the above equations are integrated over time while the voidage appearing in a selected "window" (i.e., a relatively thin horizontal slice of the bed) is sequentially recorded. The resiltant model output can then be analyzed in the same manner as the experimental data.

The results of numerous simulation runs give phase-space trajectories that appear remarkably similar to those constructed from the experimental data, even to the extent of exhibiting sudden transitions with flow reminiscent of changes in fluidization regime. By detailed comparison of model and experimental results, it has even been possible to relate some trajectory details to the occurrence of specific physical processes. It is clearly evident that the experimental trajectories contain information regarding bubble geometries, bubble size distributions, bubble velocities, and coalescence patterns.

A quantitative comparison of the model results with experimental data also shows good agreement. As with the data, the model output exhibits correlation dimensions between 2 and 5 and Kolmogorov entropies between 2 and 15 bits/s. In general, the bubble model probably underestimates both of these quantities for a given level of fluidization because of the "missing" degrees of freedom associated with lateral motion.

\subsubsection{Future Activities}

It is anticipated that activities for the coming period will be focused on collecting time series data from a broader range of experimental facilities and performing more in- depth analyses of the data. One objective will be to review the observed ranges of behavior in an attempt to define fluidization "categories" or recurring characteristic patterns of behavior. Other approaches to developing simple models of fluidized bed chaos will also be considered.

\subsubsection{References}

1. J. S. Halow and P. Nicoletti, "Observations of Fluidized Beds Using Capacitance Imaging," Powder Technology, (in press).

2. P. Grassberger and I. Procaccia, "Measuring the Strangeness of Strange Attractors," Physica D, 1983, 189-208.

3. D. S. Broomhead and G. P. King, "Extracting Qualitative Dynamics from Experimental Data," Physica 20D, 1986, 217-236. 
4. J. P. Eckmann and D. Ruelle, "Ergodic Theory of Chaos dnd Strange Attractors," Reviews of Modern Physics, Vol. 57, No. 3, Part 1, 1985, 617-654.

5. C. S. Daw and J. S. Halow, "Characterization of Voidage and Pressure Signals from Fluidized Beds Using Deterministic Chaos Theory," pp 777-786 in Proceedings of the 1991 Conference on Fluidized Bed Combustion, Montreal, April 1991.

6. J. S. Halow, G. Fasching, and P. Nicoletti, "High Resolution Capacitance Imaging of a Fluidized Bed," Proceedings of the 1991 AIChE Annual Meeting, Los Angeles, California, November 17-22.

7. C. S. Daw and J. S. Halow, "Modeling Deterministic Chaos in Gas-Fluidized Beds," Proceedings of the 1991 AIChE Annual Meeting, Los Angeles, California, November 17-22 (to be published in the AIChE Symposium Series).

\subsection{TECHNICAL SUPPORT TO PETC-USAID COLLABORATTVE COAL PROJECTS - R. P. Krishnan}

\subsubsection{Objectives}

In response to the request from the Pittsburgh Energy Technical Center (PETC), the Oak Ridge National Laboratory (ORNL) is providing technical assistance in the implementation of collaborative coal projects under the U.S. Agency for International Development (USAID)/Government of India (GOI) Phase II, Alternative Energy Resources Development (AERD) Project.

\section{2 .2 Background}

In May 1983, the GOI and the USAID initiated the AERD project with a coal conversion component comprising of six collaborative coal projects.

(1) Evaluation of freeboard performance in a fluidized bed combustor (FBC)

(2) Scale-up of an atmospheric fluidized bed combustion boiler

(3) Rheology, stability, and combustion of coal-water slurries

(4) Beneficiation of fine coals in dense media cyclones

(5) Hot gas cleanup and separation

(6) Cold gas cleanup and separation

The PETC, USDOE under a Participation Agency Service Agreement (PASA) had the management responsibility for implementing the collaborative coal projects. In the FBC projects, ORNL and BHEL, Trichy, India, were designated as the lead institutions for the collaborative efforts. 
The successful completion of the above coal projects in June 1987 led to a strong interest by the participants in the AERD coal conversion projects to continue the involvement of USAID and the USDOE in the following projects.

\subsection{Project 1: Development of Pollution Control Strategies for Abatement of $\mathrm{NO}_{\mathrm{x}}$ and $\mathrm{SO}_{2}$ Emissions from Coal-Fired Power Plants}

Nitrogen and sulfur oxide emissions from fossil-fired power plants are expected to increase significantly with the installation of additional coal-fired power plants in India. The composition and characteristics of Indian coals are different from U.S. coals and this will impact the selection of pollution control strategy. The existing data base in India on $\mathrm{NO}_{2} / \mathrm{SO}_{2}$ emissions from coal-fired power plants is not adequate to quantitatively define the magnitude of the emissions, which is the first step in the evaluation of control options.

The objectives of this project are to establish the necessary data base on $\mathrm{NO}_{x} / \mathrm{SO}_{2}$ emissions by (1) baseline monitoring in selected power plants in India using the state-of-the-art techniques developed in the U.S.; (2) testing known in-furnace control strategies practiced in the U.S. in selected power plants, in India (3) bench-and pilot-scale testing of Indian coals to quantify $\mathrm{NO}_{2} / \mathrm{SO}_{2}$ emissions; and (4) simulation and modeling of the combustion and heattransfer processes in the boiler for $\mathrm{NO}_{\mathbf{2}} / \mathrm{SO}_{2}$ prediction.

The BHEL, Trichy, will carry out the projects in India as part of their ongoing research and development on $\mathrm{NO}_{\mathbf{x}} \mathrm{SO}_{2}$ control from coal-fired power plants. Technical assistance from the U.S. will include identification and procurement of state-of-the-art equipment for $\mathrm{NO}_{\mathbf{x}} / \mathrm{SO}_{2}$ measurement, and training of the BHEL engineers in selected U.S. utilities (TVA and others) on $\mathrm{NO}_{2} / \mathrm{SO}_{2}$ monitoring and control technologies, and participation of U.S. experts in the existing bench-scale/pilot-scale testing activities at BHEL and in the baseline monitoring of Indian power plants.

\subsection{Project 2: Slagging Combustor Development for High-Ash Indian Coals}

Indian coals have ash content in the range of 35 to $50 \%$ and ash fusion temperature over $1482^{\circ} \mathrm{C}\left(2700^{\circ} \mathrm{F}\right)$. For coals of such high-ash content, it would be advantageous from the operational, reliability, and boiler life considerations if the ash can be successfully rejected as a molten slag rather than be allowed to carry over with the flue gas as in conventional pulverized fuel boilers. The slagging coal combustor (SCC) has been developed along these lines and is now in the demonstration stage in the United States. 
Recognizing the potential for this technology in India, the BHEL has an active research and development program under way. A 3.0 MW(t) process development unit has been erected and is in operation at Trichy. However, there are several fundamental and engineering issues that are yet to be resolved with respect to Indian coals (slagging potential, slag rejection - quantity and slag properties, ash carry-over from the combustor, optimum air preheat system, operating flexibility - start-up, shut-down, and effect of design parameters on slag recovery and combustor operation, carbon utilization and $\mathrm{NO}_{\downarrow} / \mathrm{SO}_{2}$ emissions) for commercial applications before the slagging combustor can be recommended for commercial applications.

The objectives of this project are to (1) demonstrate whether the slagging combustor technology is suited for Indian coals, (2) identify the engineering problems associated with the design, operation and scale-up of the combustor, and (3) design modifications needed in the BHEL slagging combustor to conduct long duration test runs on a variety of Indian coals differing in ash content and slagging tendency.

U.S. technical assistance in the design review of the BHEL slagging combustor, screening and selection of Indian coals based on their slagging potential, and on-site participation in the testing and data analysis is envisaged.

\subsection{Project 3: Characterization of Indian Coals for Combustion and Gasification}

With the deteriorating quality of coal in India (highly erosive coal) coupled with fuel switching by utilities, there is a critical need to quantify the impact of coal quality on power plant performance. Pilot-scale combustion tests are mandatory to provide boiler performance data on combustion efficiency, fuel ignition characteristics, flame stabilization, slagging, fouling, erosion and corrosion of boiler components, and gaseous and particulate emissions. Pilot-scale tests are also necessary for the full-scale burning in commercial boilers. In India, there is no facility available to conduct screening tests on coal.

The objective of this project is to design, erect and commission a pilot-scale Fuels Evaluation Test Facility (FETF) at BHEL, Trichy, which will serve as a focal point for combustion research in India. The PETC combustion research division and the ORNL will be the lead U.S. institutions collaborating with BHEL, Trichy in this project.

\subsection{Project 4: Residual Life Assessment and Life Extension of Coal-Fired Power Plants}

The assessment of remaining life of coal-fired power plant components based on quantitative, nondestructive, real-time measurements of the extent of damage to these 
components is an area which is actively pursued in most advanced countries where the latest diagnostic tools are available. The methodologies and techniques are the key to a successful remaining life assessment program. In keeping with the need for steady and reliable electric supply, the Ministry of Power, Government of India has recently embarked on a multi-million dollar power plant life assessment and rehabilitation program.

This project will be a collaborative effort, initially between the BHEL and the Electric Power Research Institute (EPRI), in which the diagnostic techniques, design criteria, methodologies, and implementation strategies developed by EPRI for the U.S. utilities will be tested in selected Indian utilities. The highly erosive nature of Indian coals will provide an opportunity to test the engineering correlations for prediction of erosion of boiler and auxiliary componerts, and possibly extended their range of applicability.

\subsubsection{Project 5: Environmental and Natural Resource Analysis of Coal Cycle}

The mining, conversion, and disposal of waste and byproducts from coal utilization have serious ervironmental repercussions in India. Although there are regulations stipulated for air and water quality pollutants, they are not strictly enforced except in urban areas. This policy is going to change in the near future, and several groups are working in the country on allowable limits, environmental considerations for power plant siting, and impact of air/water/soil quality in the vicinity of coal mines and coal burning facilities. In all these tasks, environmental system models and an environmental data base are vital. Air and water quality data are only now being collected in India, mainly around the large power plants in central India.

The goal of this project is to develop environmental system models for prediction of air and water quality near coal-based power plants. The present data base will only permit development of the overall structure of the model and the process/environmental data needed as inputs for the system model. It is expected that the inodel can be refined as more data becomes available. The methodology and the model inputs and outputs will be established in this project.

The project will be carried out by the Tata Energy Research Institute (TERI), New Delhi. Assistance to TERI will be provided by ORNL, PETC, EPA in the screening, selection and adaption of the air/water quality prediction models developed in the U.S. for local conditions. 


\subsection{Status Summary}

During this reporting period, the activities and accomplishments in each of the five coal projects are summarized below.

(1) The equipment and manpower requirements for conducting the baseline emissions monitoring were finalized with BHEL. The instrument available at BHEL for $\mathrm{NO}_{x}$ measurements does not meet the U.S. Environmental Protection Agency (USEPA) specifications. $\mathrm{SO}_{2}$ measurements have not been made in the commercial boilers and equipment for on-line $\mathrm{SO}_{2}$ measurement presently available in BHEL. Oxygen, carbon monoxide, carbon dioxide, and particulates are routinely measured, bur not on a continuous basis.

The Central Power Research Institute (CPRI) in Bangalc India, has done $\mathrm{NO}_{x} \mathrm{SO}_{2}$, $\mathrm{CO}_{2} \mathrm{O}_{2}$, and particulate monitoring in a limited number oi coal-fired plants in India. They have used a portable combustion analyzer (Westinghouse, USA equipment) for $\mathrm{CO}$, $\mathrm{CO}_{2}, \mathrm{O}_{2}$, and $\mathrm{SO}_{2}$, and a Shimodzu (Japan) analyzer for $\mathrm{NO}_{2}$ which are compatible to the instruments used in the United States for monitoring emissions. For particulates, the Anderson stack monitoring system, which is also recommended by the U.S. EPA, is used. CPRI has agreed to loan the instruments and also to participate in the emissions monitoring. The monitoring is scheduled for the first week of February 1992 and will be conducted in a 210-MW coal-fired power station in Vijayawada, India. ORNL and an engineer from Tennessee Valley Authority (TVA), Chattanooga, Tennessee will be onsite. TV'. isas a portable stack gas monitoring equipment which will be used along with the other equipment.

(2) A design review of the BHEL slagging combustor was completed to identify the modifications required in the existing combustor to improve the slag rejection. Two BHEL engineers visited the United States in June-July 1991 and spent four weeks. During this period, they visited and had discussions with several institutions involved in coal-fired slagging combustor development projects for the U.S. Department of Energy. The visits were coordinated by the Pittsburgh Energy Technology Center.

The following modifications to the existing combustor were jointly agreed upon during this visit: 
(1) Redesign the slag port with slightly larger diameter opening. Provide heating arrangement to maintain the port hot to maintain the slag fluidity and prevent it from freezing and plugging the slag port.

(2) Install a reliable coal feed system with on-line coal flow measurement for close control of coal feed rate.

(3) Enlarge the optical port for installing flow observation devices.

(4) Install sampling ports to perform isokinetic sampling of the carryover slag for determining the particle size distribution and composition of the carryover slag.

If the performance of the combustor does not improve after these modifications are made, then a radical change in the design will be required. Indications are that the present combustor which is a single-entry tangential flow system is not the optimum for slagging combustors. A double-entry system is the preferred choice for the cyclone type slagging combustors. The changeover to a double-entry system in the existing SCC would entail a substantial effort and may be difficult to complete in the current project.

(3) The design of the Fuels Evaluation Test Facility (FETF) has been completed in all essential detail to (1) arrive at the material required for the FETF (approximately 62 tons of steel) for input into the load calculations for the supporting structures and platforms, (2) estimate the refractory and insulation requirements, (3) fix the openings and location of the sampling/monitoring probes in the combustor, (4) estimate the heating surface requirements in the convection section, (5) prepare the control and instrumentation scheme for the FETF, (6) identify the plant engineering and utility requirements to operate the FETF, and (7) prepare the total package for all indigenous items to initiate the procurement process. The ground breaking for the FETF was performed on September 12, 1991. Fabrication activities have commenced. Procurement action for the indigenous equipment has been initiated by BHEL.

The only remaining activity with respect to the design is the details pertaining to the slag panel, slag probe, and the fouling probes. Clarification regarding the quantities and the flow rate of the heat transfer medium are being sought from similar facility operators in the United States through PETC. BHEL has requested ORNL to provide these details 
in order to size the pumps and flow control devices for the slag panels and probes. The heat transfer medium for the slag panel is Dowtherm.

(4) The agenda for the life extension demonstration activity at an Indian coal-fired utility has been finalized. Four U.S. experts from TVA, Chattanooga, APTECH Engineering and Failure Analysis Associates will travel to India in February 1992 to participate in the demonstration with BHEL. Two coal-fired plants with over 100,000 hours of operation have been identified for conducting the life assessment. The final site selection will depend on which plant will be available for shutdown. BHEL will communicate to ORNL the site and the requirements from the U.S. side. The life assessment will be performed on the boiler, headers, steam lines, piping and supporting structures.

(5) There was no further activity in Project 5 beyond what was reported in the previous Fossil Energy Semi-Annual Report (October 90 - March 91).

Dr. R. P. Krishnan, ORNL traveled to BHEL, Trichy in August 1991 to assist in the site activities related to the FETF. The planning and co-ordination for the power plant emissions monitoring and life assessment demonstration were completed during this visit. At the request of the USAID mission a formal presentation was made to the mission staff, BHEL and other GOI agencies on the past and current activities in the AERD coal program.

The discussions during and after the presentation focused primarily on what should be the emphasis and priority in future energy projects (the current AERD grant agreement with GOI will end in June 1992) and what steps should be taken to encourage private sector participation from both countries in commercial joint ventures in coal technologies. For details see ORNL Foreign Trip Report of R. P. Krishnan, ORNL/FTR-4055. During the next reporting period, the site-activities at BHEL, Trichy, on the FETF will continue. It is anticipated that the erection of the FETF will be in progress. Shipment of USAID equipment to Trichy will start in January 1992. The emissions monitor and life "sxtension demonstration activities will be completed during February - March 1992. 


\title{
6. FOSSIL FUEL SUPPLIES MODELING AND RESEARCH
}

\author{
P. N. Leiby
}

\subsection{STRATEGIC PETROLEUM RESERVE PLANNING AND MODEILING - P. N. Leiby and R. M. Lee}

The current fossil fuel supply-related projects assist DOE in addressing policy issues related to strategic fuel reserves, reserve drawidown, and energy security.

\subsubsection{The Refined Petroleum Product Reserve}

The Strategic Petroleum Reserve (SPR) research project initially investigated the costs and benefits of expanding the U.S. crude reserve stockpile from 700 million to 1 billion barrels and the timing of drawdowns during a supply disruption. In more recent work, the analysis turned to a separate planning question, whether part of the U.S. petroleum stockpile should be stored regionally, in the form of refined petroleum products, or centrally, as crude oil. Such a Refined Petroleum Product Reserve (RPPR) would be a part of the SPR system but might be, for example, distillate heating oil stored in New England or gasoline stored in California. Previous DOE studies have established that life cycle costs for refined product storage are significantly higher than those for centralized crude storage. Specifically, product storage facilities (possibly steel tanks rather than abandoned salt mines) would have a higher capital cost, and operating costs may be higher because of the shorter shelf life of refined products.

In investigating the feasibility of a regional gasoline reserve, we found that it would be cost-effective only if it could be completed and filled within about four years, and if the payoff (i.e., the reserve is actualiy ssed to offset a disruption) occurred almost immediately, within a year or two, of being filled. This finding is illustrated in Fig. 6.1.' The upward sloping curves indicate the cumulative costs of having a 10 million barrel reserve of gasoline under three different design options: expanding the underground facilities at the existing Big Hill site, purchasing above-ground storage tanks, or renting tanks. The cumulative costs increase over the period of constructing and filling (or renting) the reserve. The benefits are somewhat greater for larger-size disruptions. Benefits decline over time since the benefits of using the reserve are discounted more the further in the future the reserve is used. 


\subsubsection{Criteria for Decidling When to Use the SPK}

With the recent war in Kuwait and Iraq, considerable attention was given to the politically sensitive issue of when the SPR would actually be used during a disruption in the oil market. An unpublished white paper prepared by Leiby and Lee discussed different strategies and criteria that could be used for deciding on the use of the SPR. In the paper the authors discussed each of the following: ${ }^{2}$

(a) Optimizing the economic benefits of using the SPR, making explicit trade-off between using the SPR immediately or later, comparing its current value to its hedging value.

(b) Offsetting price increases, so that rapid increases would trigger use of the SPR.

(c) Offsetting physical shortages, compared to production prior to the disruption.

(d) Using contracts or other financial instruments (such as call options) that enable the market to participate in the decision on when the SPR is to be used.

(e) Using rules of thumb, such as a pre-commitment to certain policies or rules.

(f) Working with the International Energy Agency to negotiate a coordinated drawdown of the SPR.

(g) Negotiating with foreign suppliers to have increased production from those suppliers, combined with use of the SPR.

\subsubsection{Increasing the SPR Drawdown Capability}

As plans are being made to expand the size of the SPR to 1 billion barrels, the appropriate rate at which the SPR should be able to withdraw and distribute oil from the reserve is a continuing issue of debate. Increasing the drawdown capability has the benefit of allowing more oil and a more flexible mix of crude oil types to be withdrawn during acute disruptions. This increased capability comes at a cost, however, the cost of installing more pumps, building more pipelines, and enlarging terminal facilities. Study results found that the benefits of drawdown and distribution enhancement depend on the expected duration of possible disruptions and on the chosen drawdown policy. Expanding the distribution capability to 7 million barrels per day (the current plan is for expansion from 4.5 to 6.0 million barrels per day) is justified in most of the analyses, if the SPR is to be used to the maximum extent to offset disruptions in supply. This policy of using the SPR means that a disruption with a net shortage in supply, compared to production before the disruption, would be offset completely, to the extent possible by the SPR. However, this use of the SPR is not optimal from the 
standpoint of maximizing the expected economic benefits of the reserve. An optimal drawdown strategy would hedge the use of the reserve and would mean that a much smaller drawdown and distribution capability would be needed--perhaps as little as 4.5 million barrels per day. ${ }^{3}$
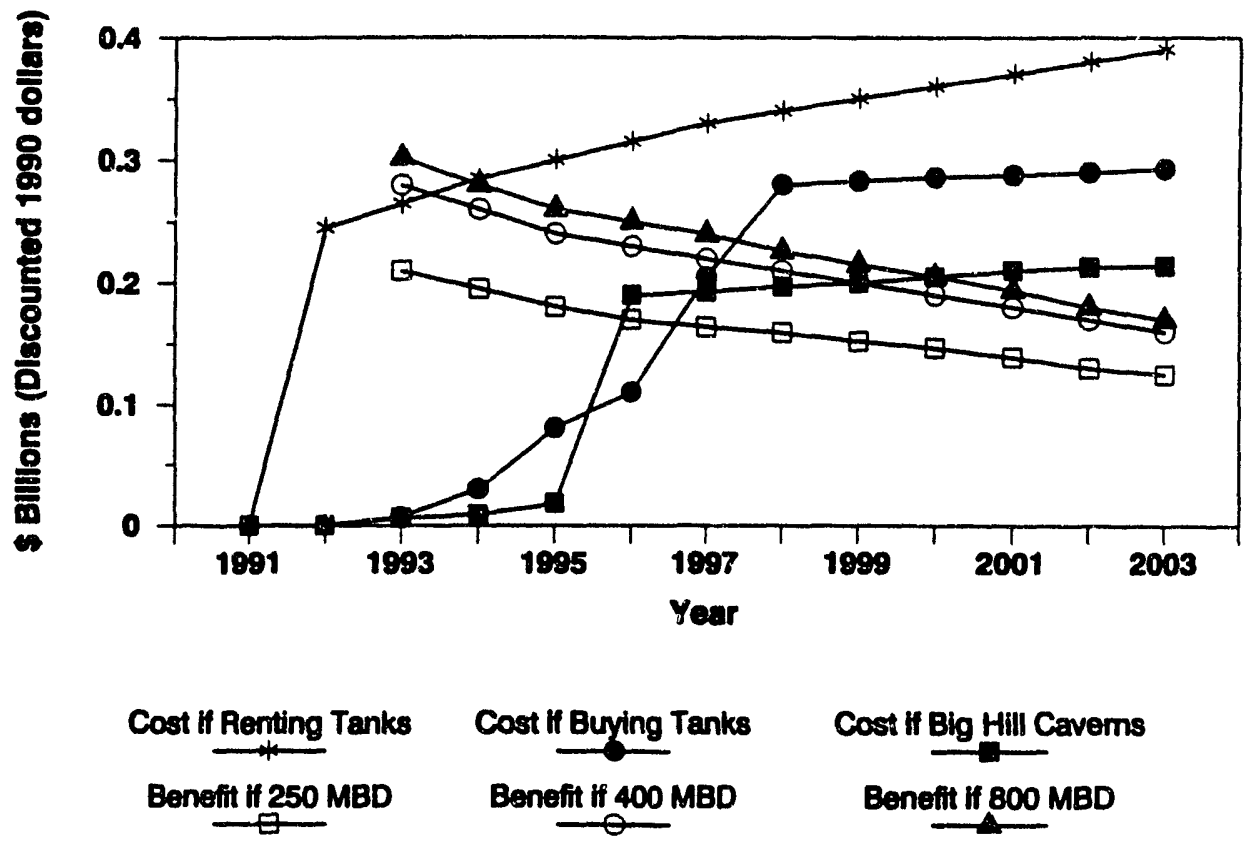

Fig. 6.1. Cumulative cost vs. benefit of a 10 million barrell reserve of gasoline.

\subsubsection{References}

1. T. R. Curlee, S. Das, R. Lee, ind P. N. Leiby, "Refined Petroleum Product Reserve (RPPR) Deterministic Cost Benefit Analysis," Briefing before the Office of Planning and Financial Management, Office of Petroleum Reserves, U.S. Department of Energy, Washington, D.C., February 15, 1991.

2. P. N. Leiby, and R. Lee, "A Discussion of Strategies and Approaches for Planning the Drawdown of the SPR," note prepared for the Office of Planning and Financial Management, Office of Petroleum Reserves, U.S. Department of Energy, Oak Ridge National Laboratory, Oak Ridge, Tennessee.

3. D. A. Trumble and R. Lee, "Benefits of Alternative Drawdown and Distribution Capabilities for the Strategic Petroleum Reserve: Results Under Revised Base Case Scenarios," draft report prepared for the Office of Planning and Financial Management, Office of Petroleum Reserves, U.S. Department of Energy, Oak Ridge National Laboratory, Oak Ridge, Tennessee. 


\title{
7. EVALUATIONS AND ASSESSMENTS
}

\author{
R. R. Judkins
}

\subsection{FUEL CYCLE EXTERNAL COST ANALYSIS - R. M. Lee and R. A. Cantor}

\subsubsection{Background}

It has long been known that the prices of using energy do not include all the costs and benefits of producing and delivering energy. Preparers of the 1990 National Energy Strategy recognized that the lack of high-quality information on external cost and benefits was distorting decision making at the federal and state levels. Consequently, a major initiative was launched by the Department of Energy (DOE) to provide best-practice information about the external physical impacts of energy use and how these impacts should be valued for planning and investment. In February 1991, DOE and the Commission of the European Communities (CEC) signed an agreement to develop a comparative analytical methodology and to develop the best range of estimates of costs from secondary sources for eight fuel cycles and four conservation options. Oak Ridge National Laboratory (ORNL) and Resources for the Future are the principal research institutions for the U.S. team.

\subsubsection{Methodology}

The principal organizational tool used in this project is the damage-function approach (DFA). Application of the DFA begins with a conceptual understanding of the impact pathways by which fuel cycle emissions "cause" physical consequences. Impact pathways identify residual emissions from fuel cycle activities and then address (1) the transport, deposition, or chemical transformations of these emissions; and (2) the physical response of ecological, human, and social resources (which are spatially and temporally distributed) to changed concentrations of pollutants. Figures 7.1-7.4 use a matrix format to display the relationships between fuel-cycle activities and residual emissions and burdens. The final step of the DFA is to consider how these physical responses are valued by the individuals affected to produce the estimates of damages or benefits.

The DFA highlights how technological and descriptive factors (such as environmental baseline and resource locations) influence the damage calculations. The DFA also forces its users to reveal what is known about physical and behaviors.l processes. Thus, the resulting "knowledge base" of the project also identifies where there are fundamantal gaps in our 
understanding about technologies, physical processes, and economic behavior that prevent quantification of damages.

\subsubsection{Progress During the Period}

Work continued during April and May on the collection of relevant health, ecological, and valuation literature. Suggested issues for the CEC team emphasis and determination of cell priorities were finalized in technical meetings with CEC staff. Meetings were organized to respond to Japanese interests, who indicated that they might join the CEC/U.S. collaboration. Technical briefings for the Japanese were held May 23-29 at the ORNL facilities. (The Japanese later decided they could not participate, due to funding constraints.)

In June, four main activies were conducted in addition to the on-going literature reviews. The regional reference environments were identified, and the location of information to support the environmental characterization was largely completed. Position papers on the uncertainty and quality message system and on the data architecture were begun. The draft guidance document, The External Costs of Fuel Cycles: Guidance Document to the Approach and Issues, was sent to DOE for review.

During July, two papers, Signalling Uncertainty and Quality of Cell Entries, and Description of Data Base Architecture, were draited and sent to the CEC team for comment. Most of the technical effort during this period was concentrated on the six cell sequences selected at the May technical meetings:

(1) coal generation contributions to ozone and the effects on crops;

(2) acid deposition effects on crops, forest, and recreation;

(3) coal mine drainage and the effects on recreational resources;

(4) ozone-related health effects;

(5) lead releases and effects on learning abilities; and

(6) coal mine radon releases and the effects on health.

Air transport and watershed modeling efforts were well underway, and the reference environments were defined and characterized. ORNL team members met with Jacques Lochard of CEPN to discuss the technologies to be explored for CEC's nuclear fuel cycle analysis. They also met with contacts in the Conservation and Renewables program of DOE regarding the biomass analysis. 
In August, the documentation of data references and sources for the regional reference environments was completed and distributed to team members. In the economic valuation areas, the literature review was completed for quantity changes in fishing resources, mortality, and many morbidity effects. Also, the research team made good progress with an analysis of occupational health effects to distinguish externalities from internalized costs.

Resources for the Future prepared a memo report detailing the major issues for the Energy/Economic/Environmental Systems Analysis modeling task. The report discusses the complex interrelationships that exist between the production of market goods and services, the provision of nonmarket goods and services, and the values placed by individuals on these two classes of goods and services. Issues that are important for pursuing this modeling include definitions of man-made and natural capital, commercial and household production, marketed and nonmarketed services, and residual products at capture both waste and intermediateproduct features.

A paper outlining possible software options for a computer system that can address simultaneously the data base management needs and the analytical demands of our application was prepared and sent to DOE for comments. Overall, we are not optimistic that ORACLE (or any other currently available system) can fulfill this application. While it is possible that a software system (using ORACLE as a base) could be developed specifically for our problem, it would be beyond the current scope and budget of the project. This issue will be discussed with the CEC team in October.

Information was received from Cindy Riley (SERI) that addresses a total fuel cycle analysis for ethanol from waste (1990) and energy crops (2010) using reformulated gasoline as the benchmark. This work will complement our onwn efforts in the biomass and oil areas, providing information to a knowledge base that is currently very limited.

In September, project staff met with Hilary Smith and Tom Grahame of DOE to discuss revisions for the Guidance Document. It was decided to restructure the introduction and add a new chapter on the analytical tools of the project.

Preparations were begun for a meeting with CEC staff to be held next month.

\subsection{ANALYTICAL ASSISTANCE AND ANALYSIS FOR THE STRATEGIC PETROLEUM RESERVE - J. H. Stewart, Jr. and W. R. Laing}

The simultaneous multielement analysis of crude oils at the parts-per-billion concentration levels has been achieved by combining chemical destruction of the crude oil with 
the detection sensitivity of the inductively coupled plasma mass spectrometer (ICP/MS) analyzer system. The four chemical preparation techniques evaluated were open vessel acid digestion, open vessel microwave digestion, high pressure sealed-vessel microwave digestion, and high pressure sealed tube digestion. Both sealed-vessel techniques were successful in retaining volatile elements (As, $\mathrm{P}, \mathrm{Se}$ ) while accomplishing destruction of the organic matrix. The resulting aqueous nitric acid solution was injected into the ICP/MS spectrometer for measurement of the elements of interest in the low parts-per-billion concentration range.

The most difficult steps in this program involved the blending of the oils to achieve a homogeneous specimen, followed by chemical destruction of the organic without loss of the volatile elements of interest. The open vessel digestion was completely unsatisfactory for As, $P$, and Se. The CEM Corporation microwave closed-vessel digestion and the Anton-Parr high pressure digestion system produced acceptable aqueous nitric acid solutions for analysis. The preparation solutions from these digestions were then evaluated for trace metals recovery by ICP-optical emission analysis at both ORNL and the K-25 site, and by ICP/MS at ORNL.

These closed-system digestion comparative data (Table 7.1) clearly show that the trace element recovery is excellent.

Table 7.1. Comparison of results for Conostan C-21 by three dissolution procedures and analysis by ICP/OE and ICP/MS

\begin{tabular}{lccccccc}
\hline & \multicolumn{2}{c}{ Open Digestion } & \multicolumn{2}{c}{ HPA-Closed } & \multicolumn{3}{c}{ Microwave-Closed $^{2}$} \\
\cline { 2 - 8 } Element & $\begin{array}{c}\text { \% } \\
\text { Recovery }\end{array}$ & $\begin{array}{c}\text { \% } \\
\text { RSD }\end{array}$ & ORNL/CP & K25/CP & $\begin{array}{c}\text { ORNL } \\
\text { ICP/MS }\end{array}$ & ICP & ICP/MS \\
\hline $\mathrm{Al}$ & 108 & 3.6 & 100 & 99 & 93.6 & 111 & 106 \\
$\mathrm{As}$ & 26 & 8.3 & 99 & 99 & 80 & 100 & 100 \\
$\mathrm{Ba}$ & 102 & 2.7 & 88 & 88 & 81 & 102 & 88 \\
$\mathrm{Cd}$ & 101 & 3.6 & 102 & 104 & -- & 106 & $\ldots$ \\
$\mathrm{Cr}$ & 105 & 5.0 & 104 & 101 & 94 & 111 & 103 \\
$\mathrm{Cu}$ & 99 & 4.0 & 102 & 106 & 96 & 107 & 102 \\
$\mathrm{Mg}$ & 104 & 3.8 & 101 & 100 & 92 & 107 & 102 \\
$\mathrm{Mn}$ & 98 & 16 & 106 & 107 & 104 & 111 & 107 \\
$\mathrm{Mo}$ & 101 & 3.2 & 83 & 88 & 84 & 110 & 104 \\
$\mathrm{Ni}$ & 102 & 1.9 & 102 & 103 & 98 & 109 & 102 \\
$\mathrm{P}$ & 21 & 33 & 100 & 86 & 63 & 102 & 100 \\
$\mathrm{~Pb}$ & 110 & 3.0 & 101 & 100 & 98 & 111 & 102 \\
$\mathrm{Se}$ & 7.2 & 64 & 99 & 105 & 89 & 100 & 92 \\
$\mathrm{Sn}$ & 52 & 2.0 & 52 &.- & 46 & 38 & 45 \\
$\mathrm{~V}$ & 104 & 1.9 & 100 & 100 & 92 & 107 & 101 \\
$\mathrm{Zn}$ & 112 & 5.1 & 106 & 103 & 97 & 108 & 103 \\
& & & & & & & \\
\hline
\end{tabular}

1Work of April 1989

2High Pressure Asher, Rep. Amer. Laboratory, March 1986

${ }^{3}$ Microwave Digestions by Sara Littau, CEM Corp. 


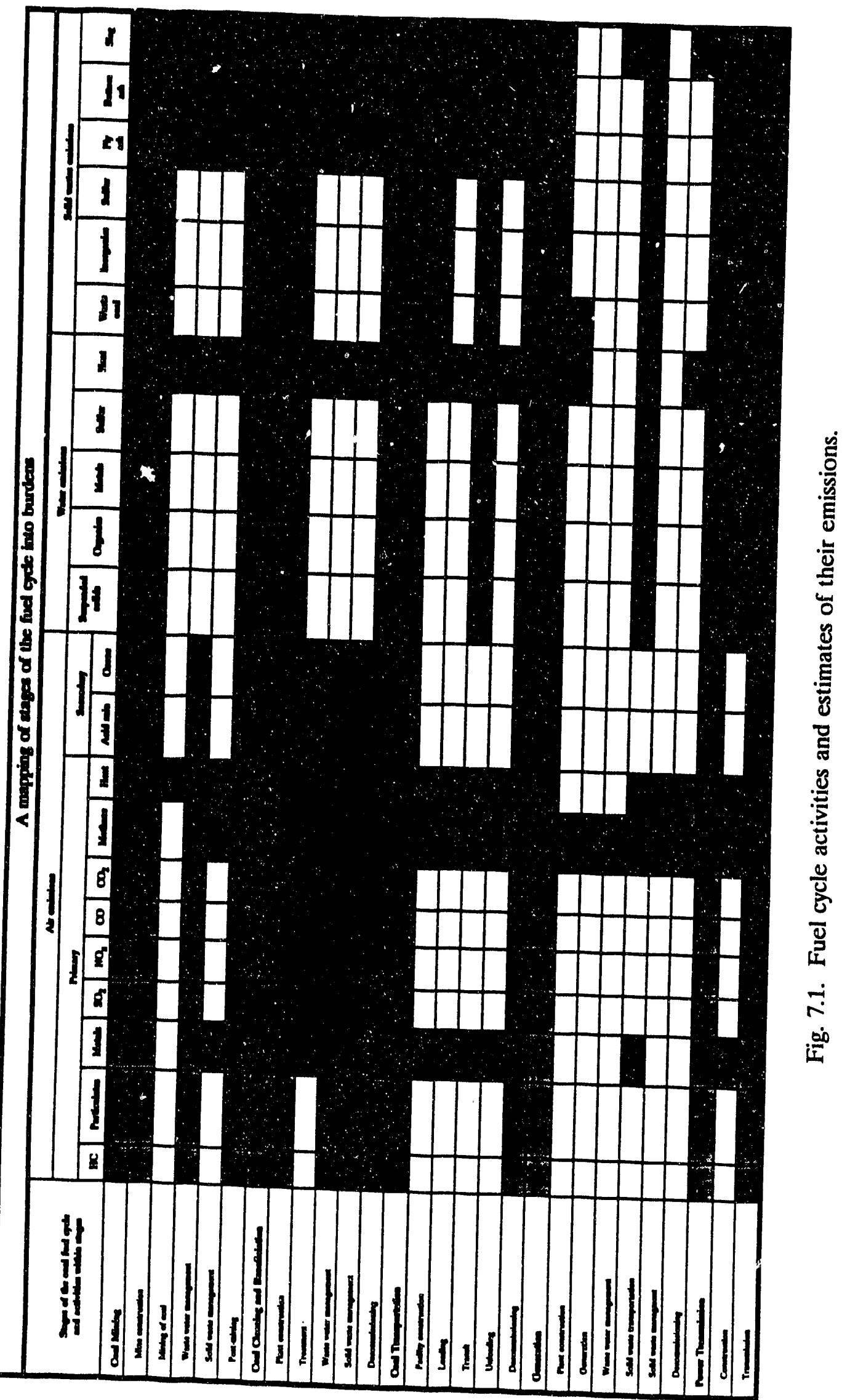




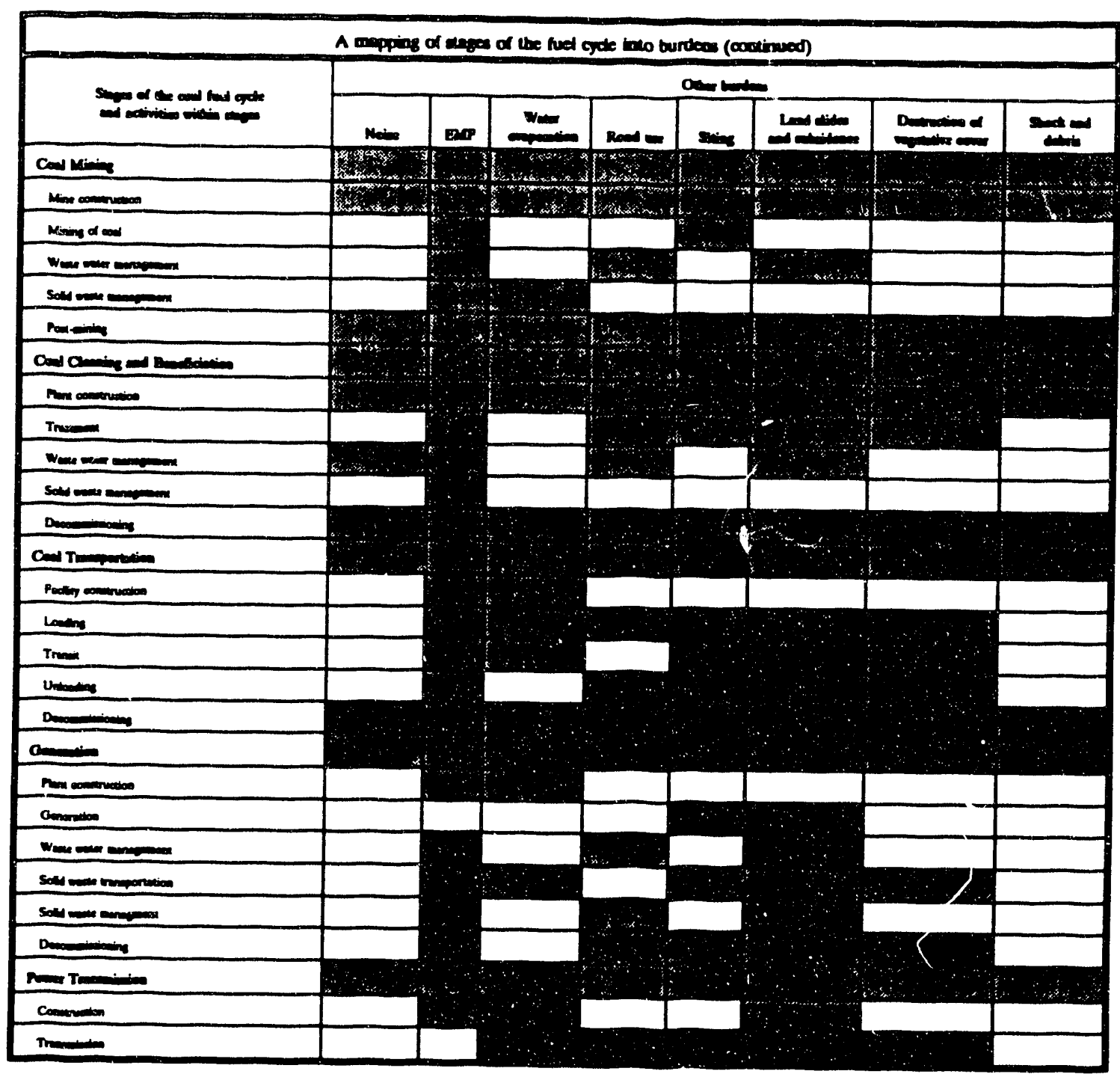

Fig. 7.2. Fuel cycle activities and estimates of their burdens. 


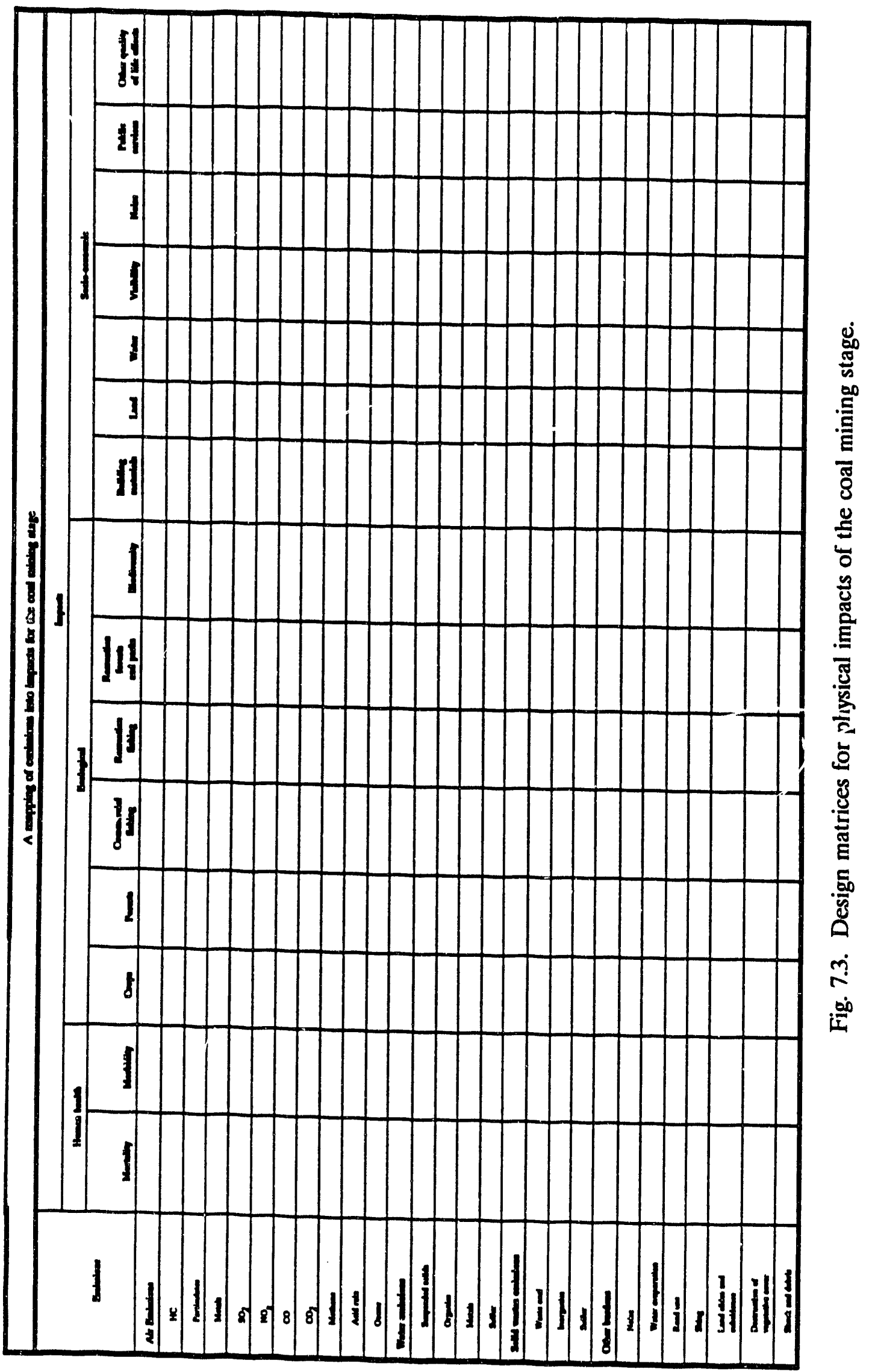




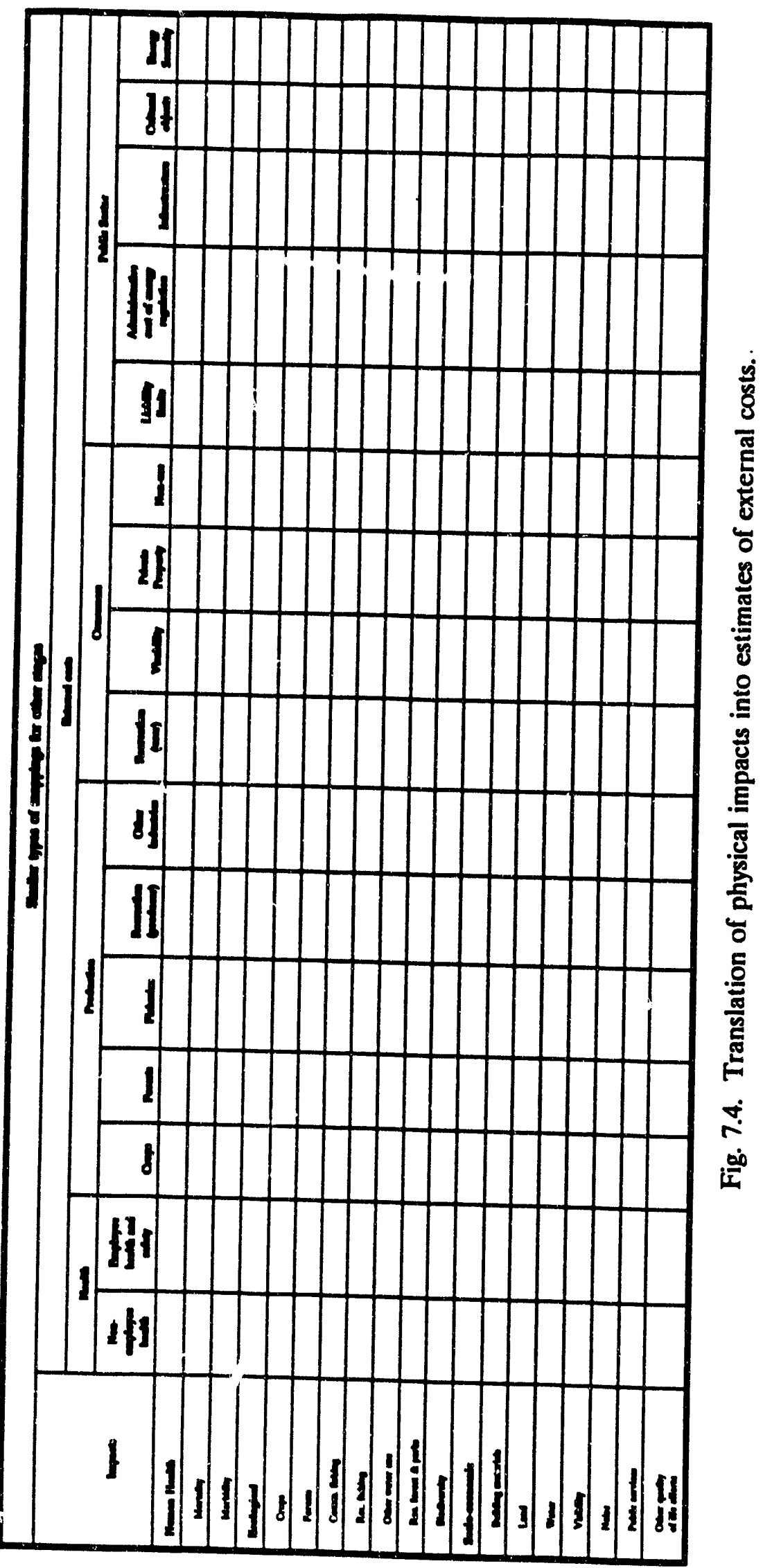




\title{
8. COAL STRUCTURE AND CHEMISTRY
}

\author{
R. R. Judkins
}

\subsection{INVESTIGATION OF COAL SURFACES AND INTERFACES - L. F. Allard,} A. Choudhury, T. A. Nolan, and V. J. Tennery

During this period, research on the analytical characterization of coal surfaces and interfaces between coal and various minerals was completed. Observations of pyrite microcrystals comprising framboid structures in bulk coal specimens that revealed a significant fraction of individual "crystallites" were in fact polycrystalline in nature. The results of the oxidation studies performed as a part of this project suggest that further work could be beneficial in terms of understanding surface and interfacial phenomena of mineral impurities in coal.

\subsubsection{Introduction and Summary}

The principal objective of this study was to provide analytical characterization of coal surfaces and interfaces between coal and various included minerals, for the purpose of assisting the Pittsburgh Energy Technology Center in its research on coal characterization and cleaning. This project included the study of the chemistry and structure of coals as well as the properties of surfaces and interfaces. Particular emphasis has been given to the surface chemical state of the sulfur bearing minerals, primarily pyrite. The major techniques utilized in these studies were transmission and scanning electron microscopy (TEM and SEM), and X-ray photoelectron spectroscopy (XPS).

Microstructural characterization of coal specimens revealed that small pyrite particles appeared to be coated with thin layers of a material having a different composition. Energy dispersive $\mathrm{X}$-ray analysis (EDS) indicated that this material had an elemental composition similar to that of iron hydroxide. In order to gain more knowledge about the surface chemical state of pyrites, fundamental studies of the oxidation of pyrite were conducted. Single crystals of pyrite suitable for TEM and XPS were prepared from bulk crystals of mineral-derived pyrite. These were oxidized and the resulting specimens were characterized and compared to unoxidized specimens. The formation of goethite, an iron hydroxide, on the surfaces of the pyrite was confirmed. This work has been completed and results are reported herein. 


\subsection{Research Results}

\subsection{Coal Pyrite Structure and Morphology}

The first portion of this study was devoted to the characterization of pyrite particles found in coal. Although several coals were studied, the major effort involved specimens of Pittsburgh \#8 coal. ${ }^{1}$ Fig. 8.1 shows an area of Pittsburgh \#8 coal having a lamellar region of mineral inclusions, parallel to the bedding plane within an apparent vitrinite matrix. Two discrete particulate morphologies were seen in this region, as is evident in Figs. 8.1b and 8.1c. Fig. 8.1b shows a particle which appears to have been formed from a collection of particles that agglomerated into a solid mass, while Fig. 8.1c shows individual crystallites collected in a "framboidal" morphology. ${ }^{2-4} A$ thin section prepared by ion beam milling techniques through this region of mineral matter showed (Fig. 8.2) collections of angular crystallites in the size range of 0.5 to $1.0 \mu \mathrm{m}$ diameter. These are consistent with the morphology observed in Fig. 8.1c. Energy dispersive X-ray spectra and electron diffraction patterns acquired from the crystallites (discussed in detail later) confirmed that the crystallites were FeS2 having a pyrite (rather than marcasite) structure.

Typical results of the TEM analyses are described here with reference to the higher magnification image of Fig. 8.3. Particle 1 was oriented to give the diffraction pattern shown in Fig. 8.4a. This pattern shows that the particle is essentially a single crystal, and is consistent with a $\langle 100\rangle$ (cube axis) orientation for the cubic pyrite phase. When properly oriented with respect to the image, the pattern indicates that the edges of the crystallite are in $\langle 110\rangle$ directions. This is consistent with an octahedral shape for the particle, with octahedral facets parallel to $\{111\}$ close-packed planes in the structure. The additional reflections (arrowed) result from double diffraction effects. Faint $\{011\}$ type reflections (also arrowed) result from an apparent stacking fault structure running across the particle diagonal. In contrast to the single crystal form of particle 1, particle 2 gives the diffraction pattern of Fig. $8.4 \mathrm{~b}$, a ring pattern that indicates a polycrystalline morphology.

The EDS spectrum from particle 1 (Fig. 8.5a) compared to a spectrum from a standard of pyrite (Fig. 8.5b) is consistent with the identification of pyrite as the crystalline composition of the particle. The EDS spectrum from particle 2 is shown in Fig. 8.6, and indicates that the composition is similar to that of particle 1. The ring pattern also indexes consistent with the pyrite phase. Although the particle is polycrystalline, the straight, linear outline of the particle suggests a prior single crystal nature for the particle, possibly the result of a topochemical 
ORNL Photo YP-10902

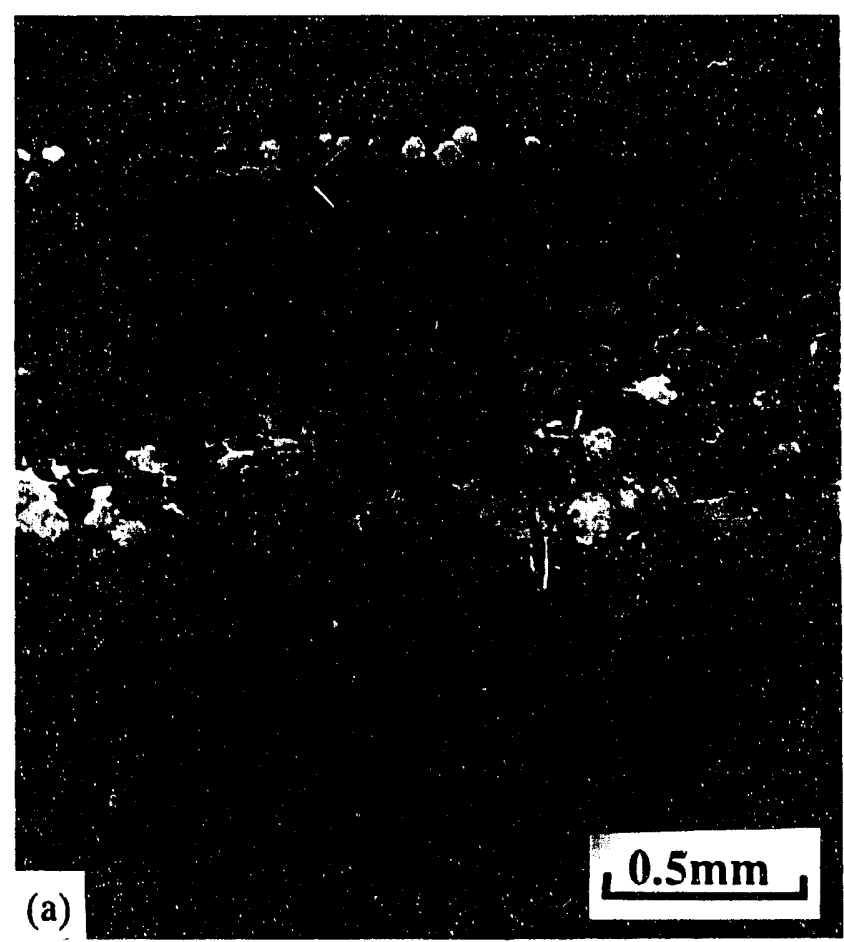

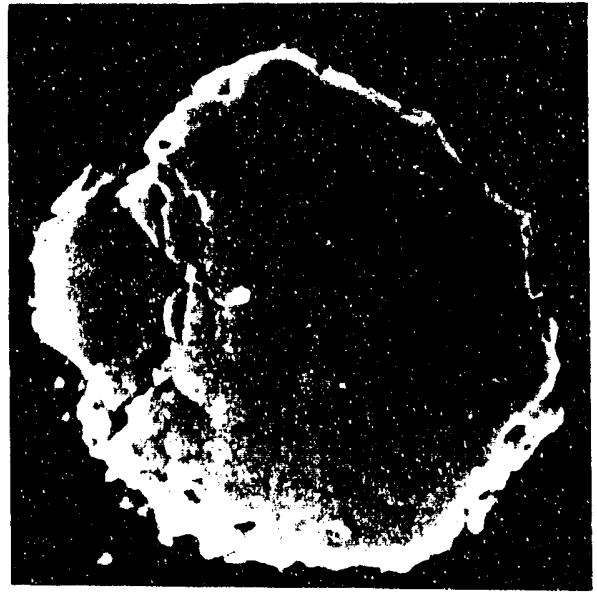

(b)

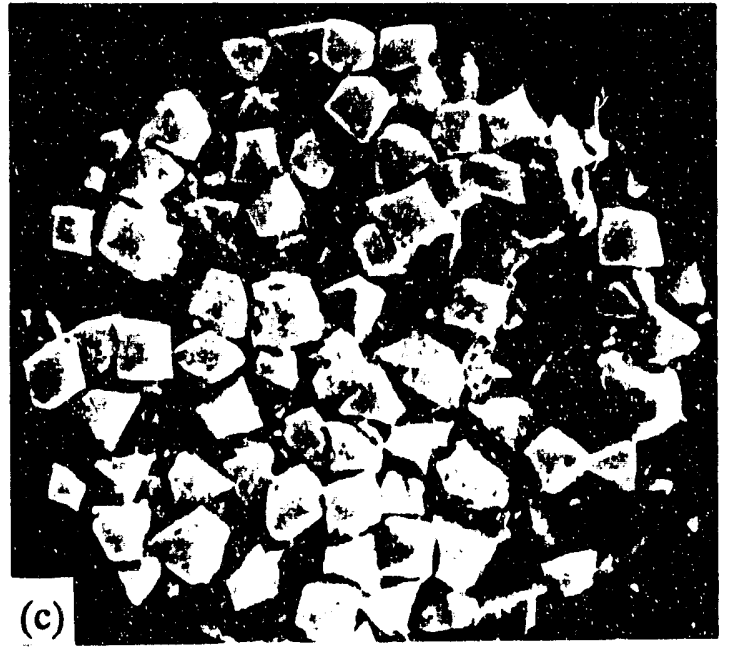

5um

Fig. 8.1. SEM image of a Praxis Pittsburgh bituminous coal showing (a) lamellar regions of mineral matter within a vitrinite matrix; (b) typical framboidal morphology, and (c) typical particle agglomerates from region above. 


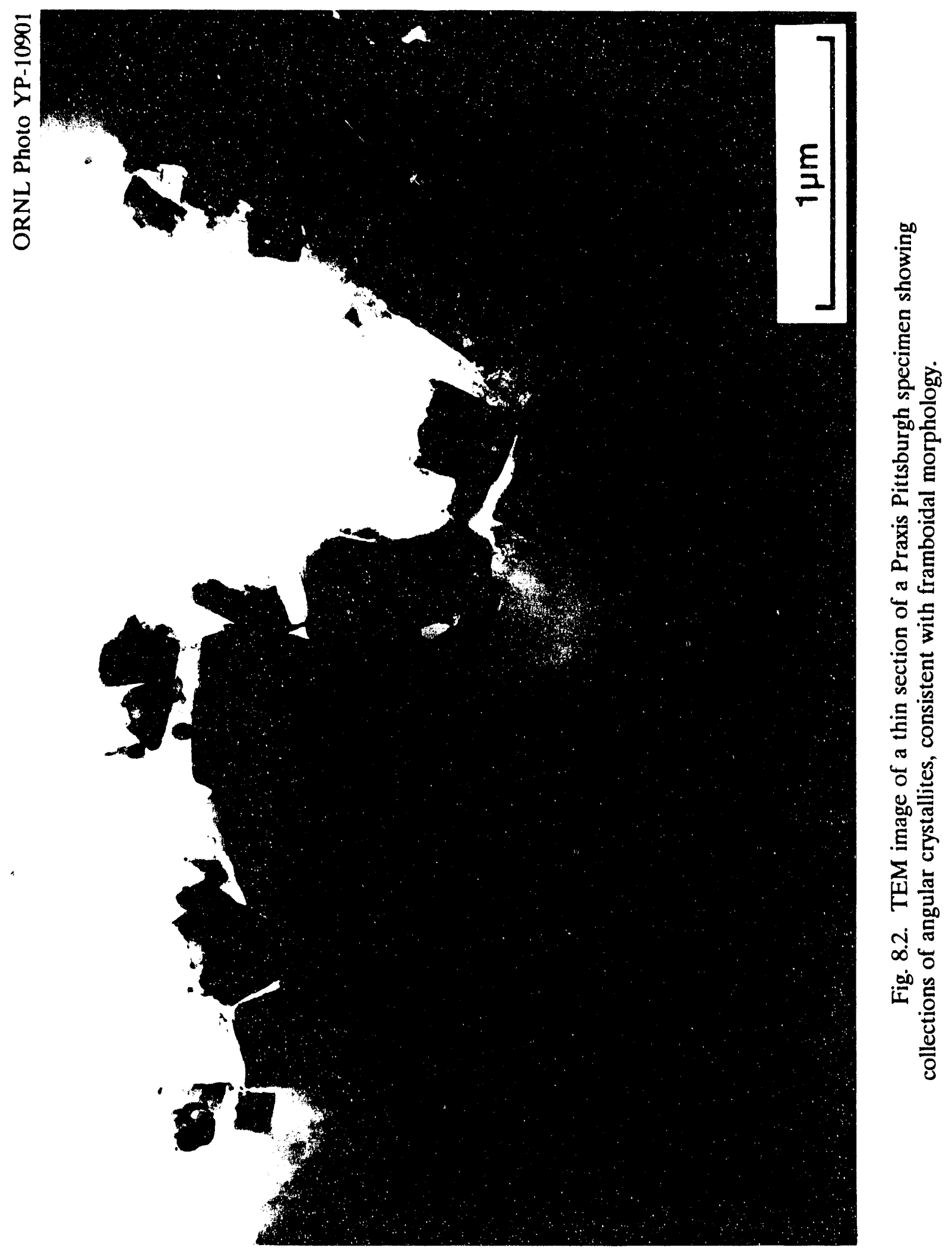




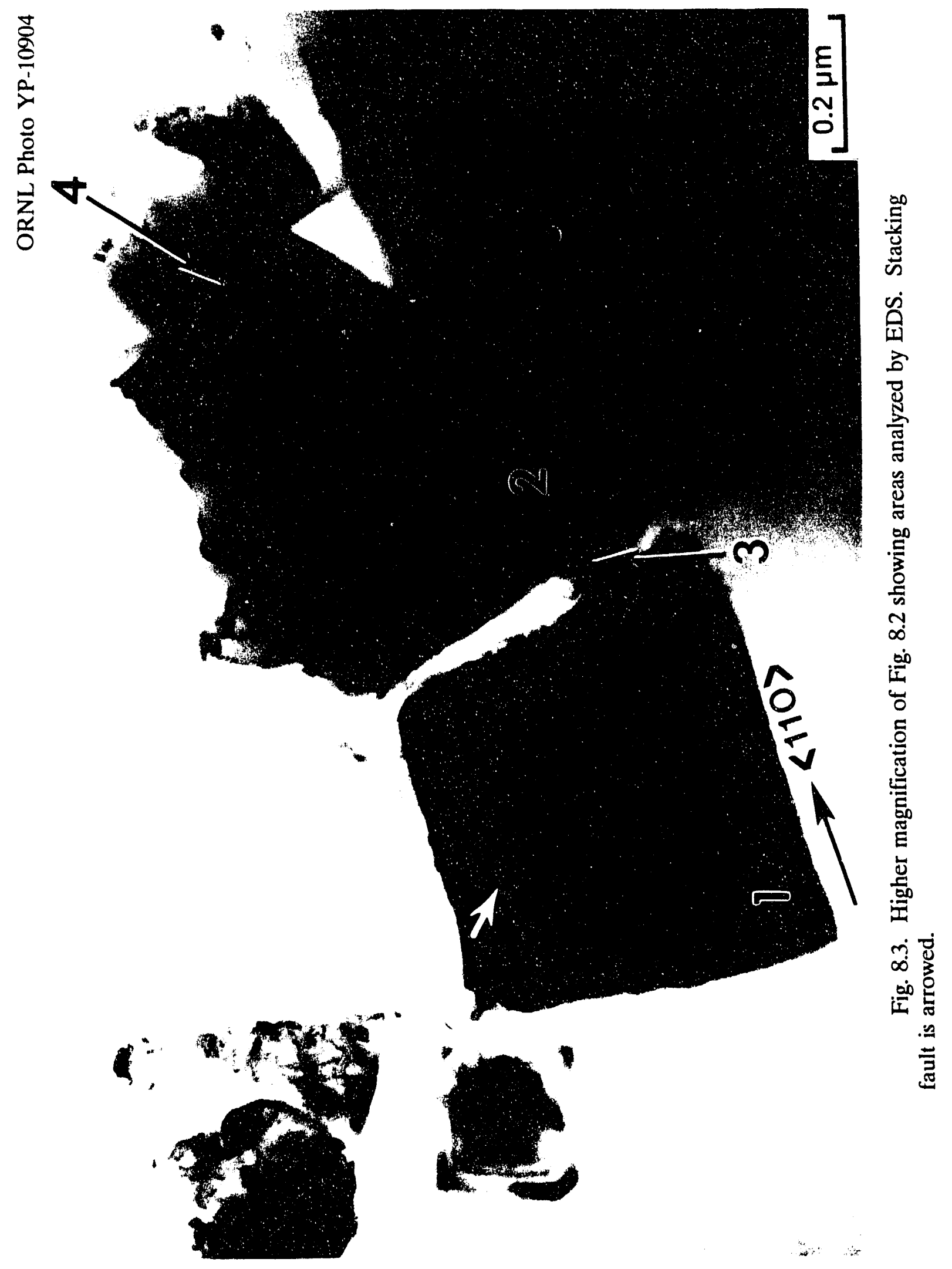


ORNL Photo YP-10903
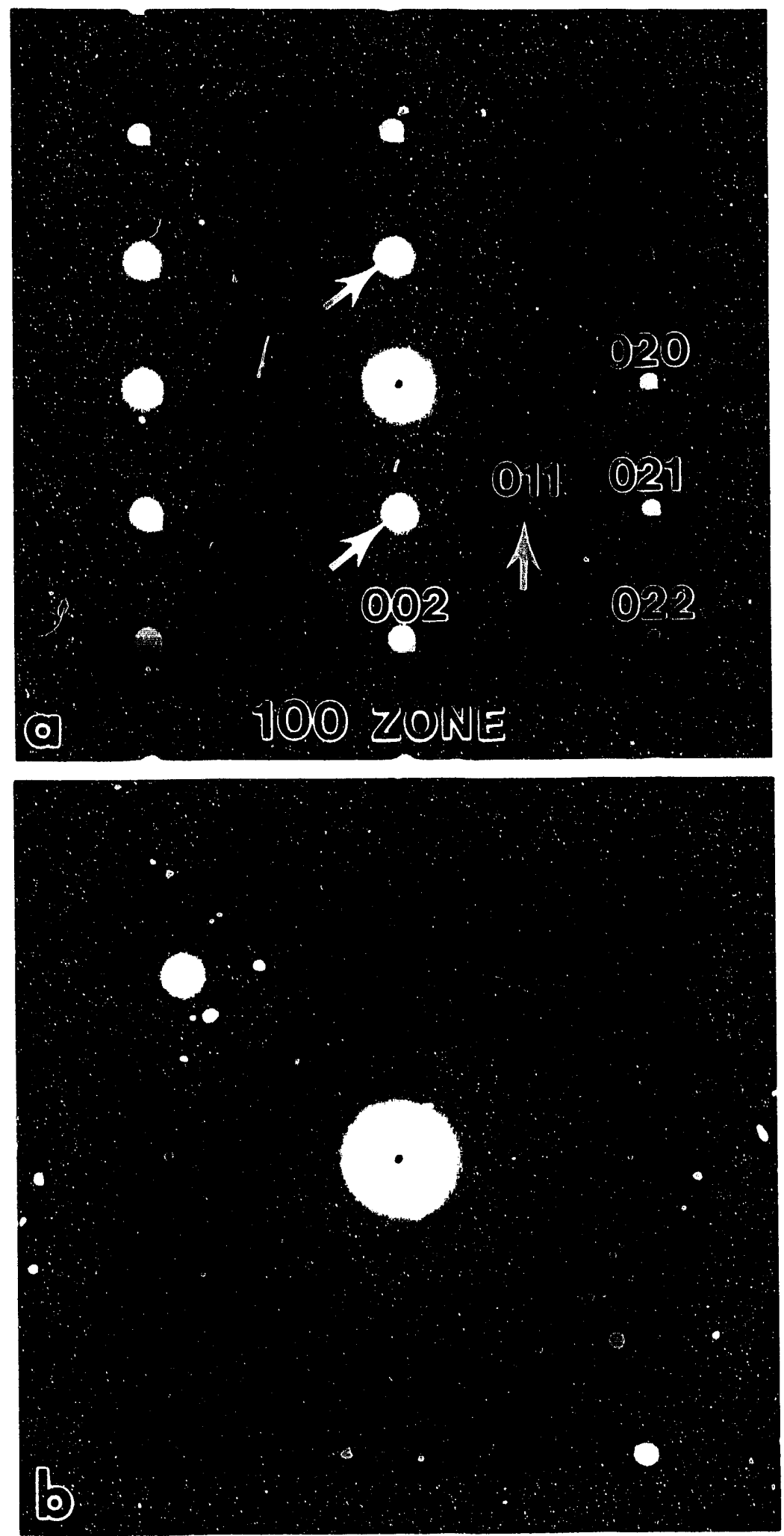

Fig. 8.4. (a) Diffraction pattern of a single crystal of the cubic pyrite phase in a $<100>$ zone axis orientation. Additional reflections (arrowed) result from double diffraction effects. Faint $\{011\}$ reflections result from a stacking fault running across particle diagnonal. (b) Diffraction pattern of particle 2 showing polycrystalline nature of particle. 
ORNL Photo YP-13783
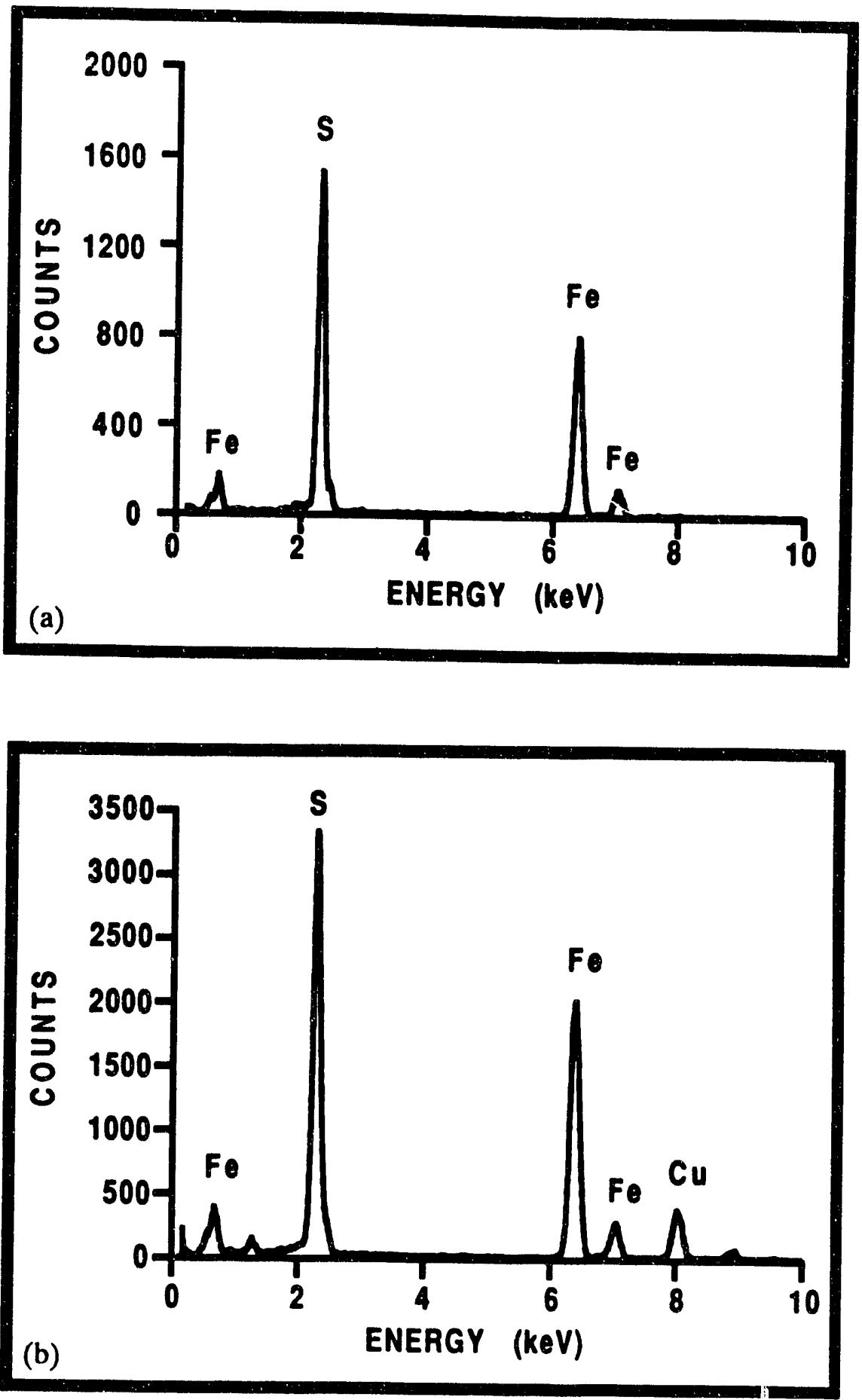

Fig. 8.5. (a) EDS spectrum of particle 1, (b) EDS spectrum of a pyrite standard. The $\mathrm{Cu}$ peak in Fig. $5 \mathrm{~b}$ results from the $\mathrm{Cu}$ specimen grid used to support particles of a pyrite standard. 


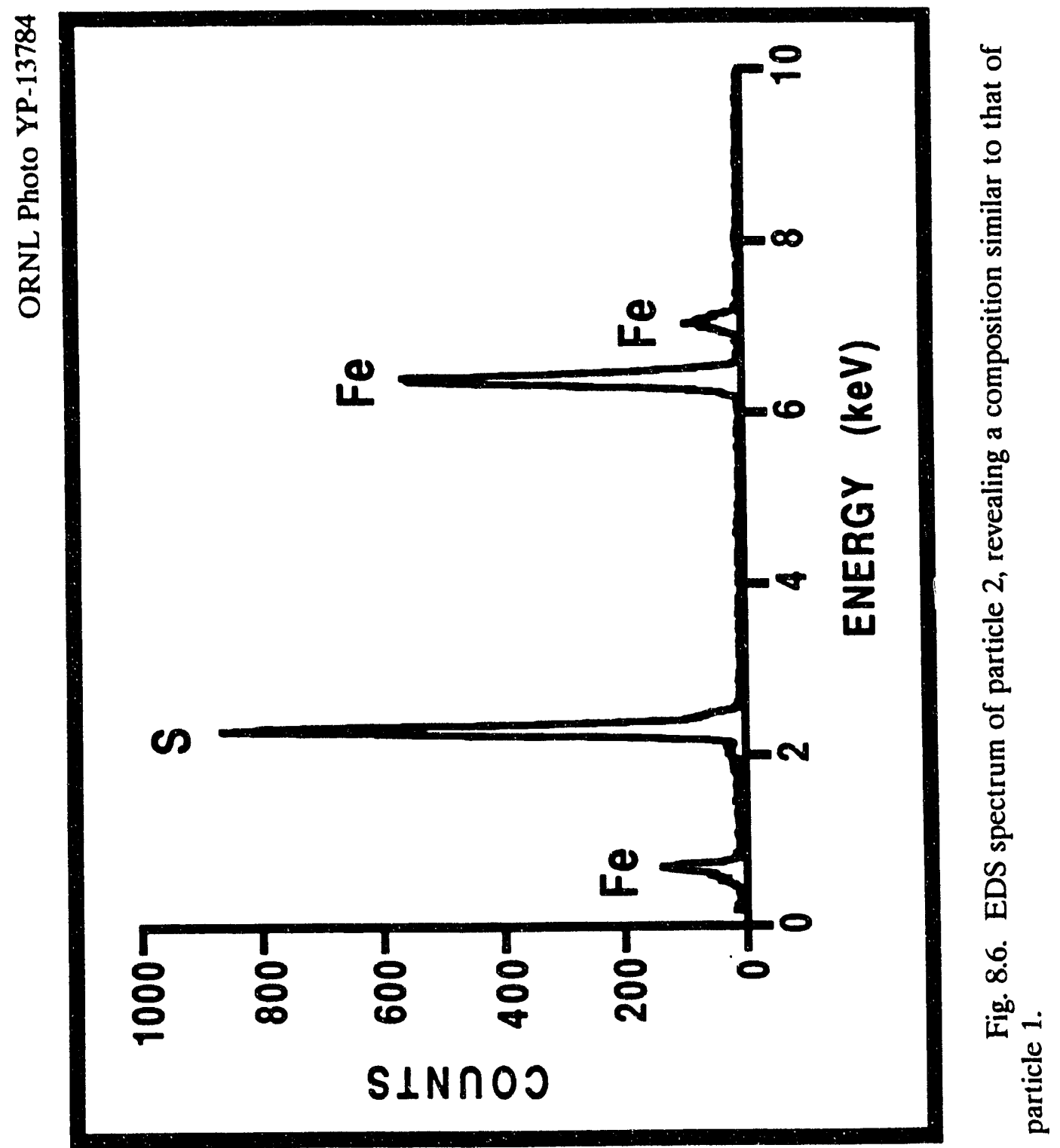


reaction. Similar analyses of a number of other particles in the agglomerate indicate that there are essentially equal numbers of the polycrystalline and single crystalline particles in the agglomerate.

The interparticle phase boundaries were characterized by further EDS analyses. For example, the matter located between particles 1 and 2 gave the EDS spectrum of Fig. 8.7a. This shows both $\mathrm{O}$ and $\mathrm{Si}$ in significant amounts in this region (which may result from the local presence of a silicate mineral). The strong $\mathrm{Si}$ and $\mathrm{Fe}$ peaks are contributed by excitation of the bulk of the particles by the beam. In contrast, the amorphous matter between particles 2 and 3 (Fig. 8.7b) shows only $\mathrm{O}$ in addition to $\mathrm{S}$ and $\mathrm{Fe}$, and the increase in the intensity of Fe relative to $S$ in this area suggests the presence of an iron oxide or iron hydroxide phase. The amorphous nature of the intergranular material suggests that an hydroxide phase is more likely. Thus, it would appear that the surfaces of small pyrite particles are covered with at least one second phase compound.

Beneficiation processes that involve surface chemical state (hydrophobicity, for example) that are utilized to separate pyrite particles from coals can be expected to be strongly affected by the surface chemical composition. Thus, the next project direction was to study in detail the oxidation of pyrite surfaces.

\subsection{Mineral Pyrite Crystal Structure and Specimen Preparation for TEM}

Large single-crystalline specimens are ideal for characterization of corrosion phenomena. By appropriate preparation, various crystallographic planes can be exposed, thus simplifying the determination of orientations and any epitaxical relationships that may exist between substrate and corrosion-produced phases. Differences in corrosion rates of various crystallographic faces can be observed by appropriate slicing and polishing of larger single crystals. Thus mineral pyrite specimens having large facets indicative of large single crystals were utilized to produce both TEM and XPS specimens.

First attempts at producing thin single crystal foils for TEM gave surprising results. Samples were prepared by slicing pyrite cubes appropriately to expose the desired surface orientations. Thin foils prepared from these samples showed a fine-grained polycrystalline structure (Fig. 8.8), even though the bulk specimen had perfect facets typical of single crystal structures. Some single crystal specimens häving a $\{100\}$ orientation and a size suitable for both TEM and XPS have been successfully prepared by slicing pyrite cubes so that the specimens were comprised of near-surface material (Fig. 8.9). These results are typical of 
ORNL Photo YP-13788
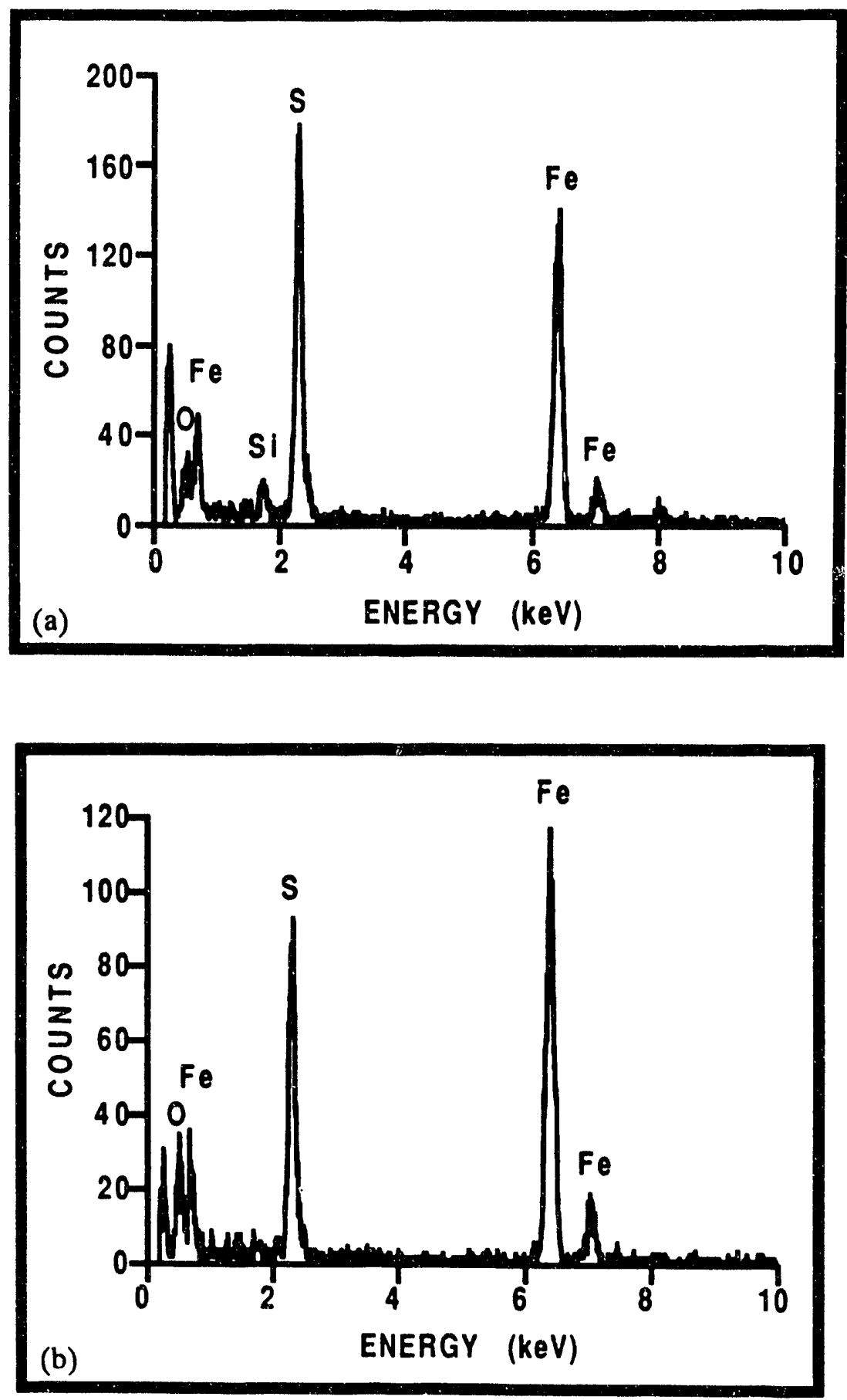

Fig. 8.7. (a) EDS spectrum of the interface between particles 1 and 2 (point 3), showing both $\mathrm{O}$ and $\mathrm{Si}$, (b) EDS spectrum of the interface between particles 2 and 3 (point 4). The amorphous material having an oxygen-rich Fe composition suggests the presence of an iron hydroxide surface layer. 
ORNL Photo YP-13786

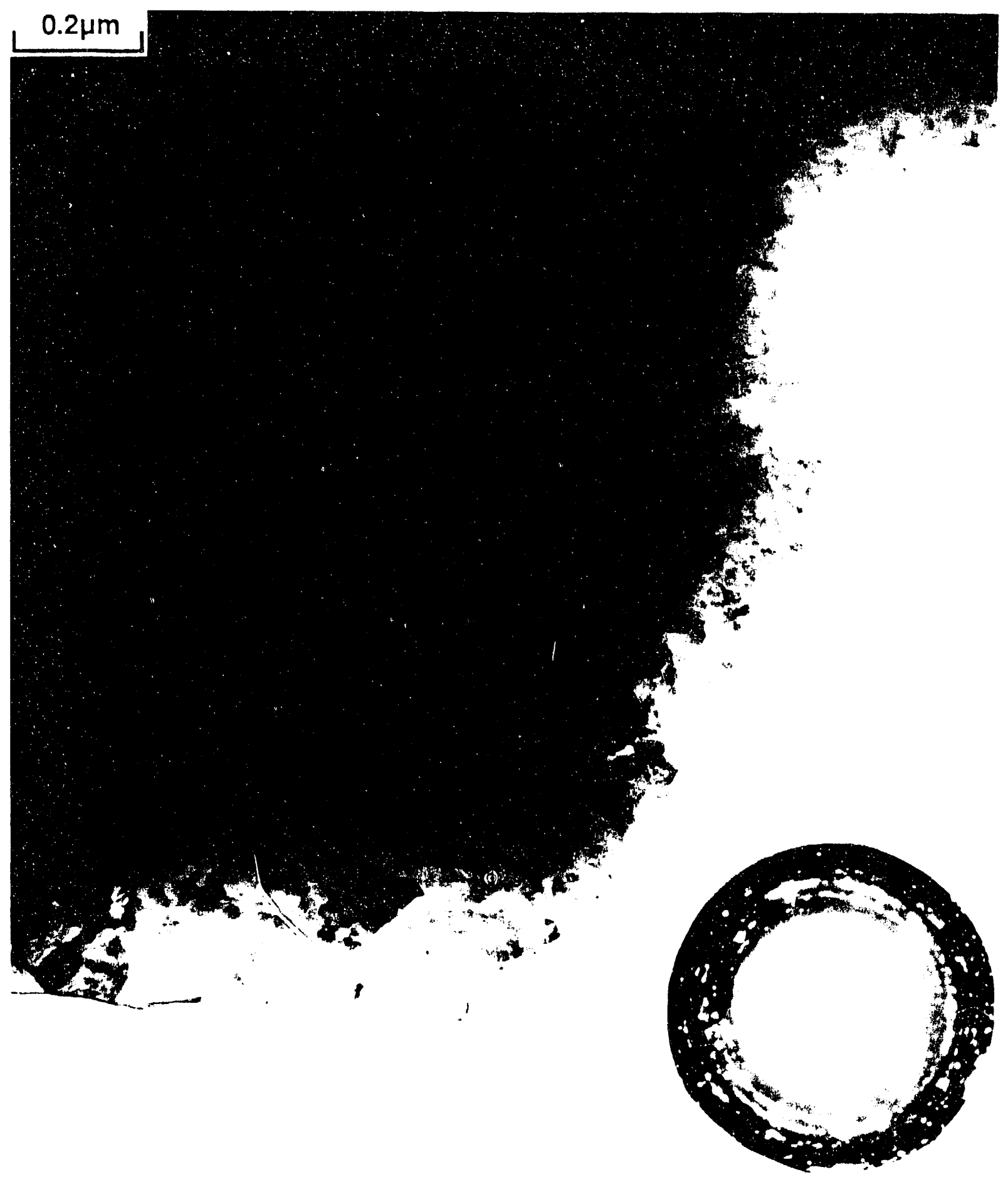

Fig. 8.8. TEM image of a bulk cube-shaped crystal sectioned through the center of the crystal, looking normal to the cube face (a $<100>$ direction). The internal structure of this crystal is polycrystalline (confirmed by the ring nature of the inset electron diffraction pattern) with a grain size of 10 to $50 \mathrm{~nm}$. 


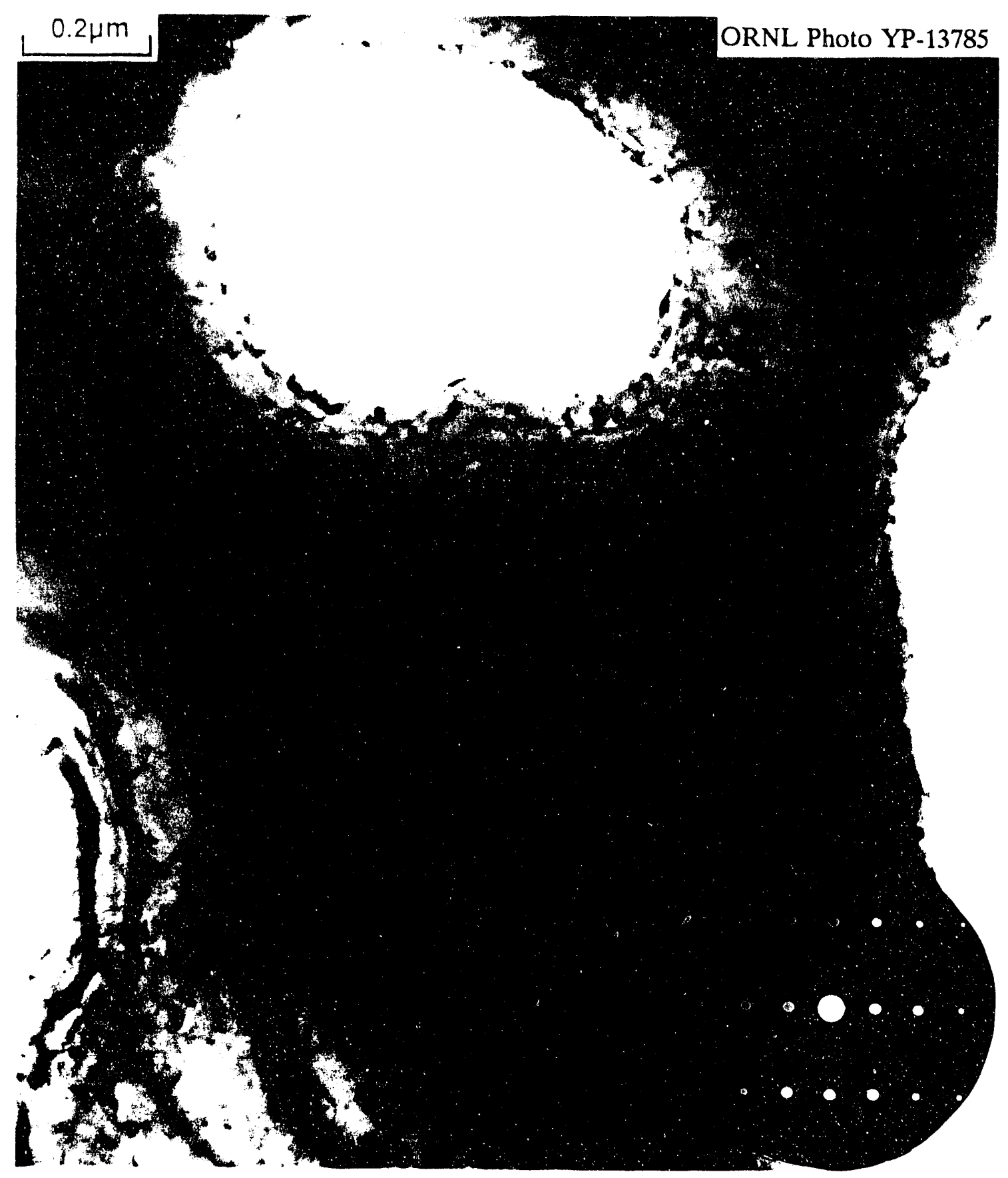

Fig. 8.9. TEM image of a bulk cube-shaped crystal sectioned through a nearsurfacc layer, looking normal to the cube face as in Fig. 8.8. The structure at the surface of the crystal is single crystalline, as indicated by the inset electron diffraction. 
those obtained from bulk pyrite specimens obtained from several different geographical locations. This suggests that only the very-near surface material on any bulk pyrite crystal is actually single-crystalline in nature. It is interesting that the facetted polycrystalline microcrystals which comprise the framboid structures in coal are mimicked in structure by facetted bulk crystals which also have a polycrystalline internal structure.

The TEM foils that are prepared utilizing a final step of ion-milling are typically contaminated with a minor growth of some compound that causes the faint polycrystalline rings seen in the inset diffraction pattern and results in the mottled contrast seen in the image of the foil. An additional preparation step, consisting of low voltage ion-milling for a short period of time with the ion beams adjusted to a very small incidence angle, sufficed to remove this extraneous material.

\subsubsection{First Pyrite Oxidation Experiment}

The first oxidation experiment had as a principal goal the determination of the conditions necessary to produce quantities of corrosion products adequate for analysis by electron microscopy techniques and X-ray diffraction. Subsequent corrosion experiments would then be performed under conditions that would facilitate analysis. In the first oxidation experiment, ion-milled pyrite specimens suitable for TEM, and larger specimens suitable for $\mathrm{X}$-ray diffraction and XPS were exposed to air at $95 \%$ or greater relative humidity for one week at $60^{\circ} \mathrm{C}$. At no time was water observed to have condensed to form visually observable droplets on the specimens, nor was any liquid scen on the specimen holder. Fortunately, in this first experiment, corrosion products were produced that were ideal for TEM characterization. The quantity of products formed were also adequate for X-ray diffraction; however, they were too thick to be ideal for XPS since sputter times for depth profiling to penetrate the corrosion layer would be excessive.

The specimens lost their shiny brass lustre during exposure and were a matte-finish tan-brown color after exposure. Scanning electron microscopy (SEM) was performed on the surface of the TEM specimen. At least two distinct morphologies were associated with the deposit. A thin, relatively uniform, fine granular deposit covered the entire surface of the specimen (see regions around A, Figs. 8.10a and 8.10b). Thick, discrete pards of deposit were also observed (see B, Figs. 8.10a and 8.10b). Many of the pads of corrosion contained very small particles or crystallites which were visible at high magnification (Fig. 8.11). The uniform fine-grain film was visible in the TEM where the pyrite had been completely reacted away 

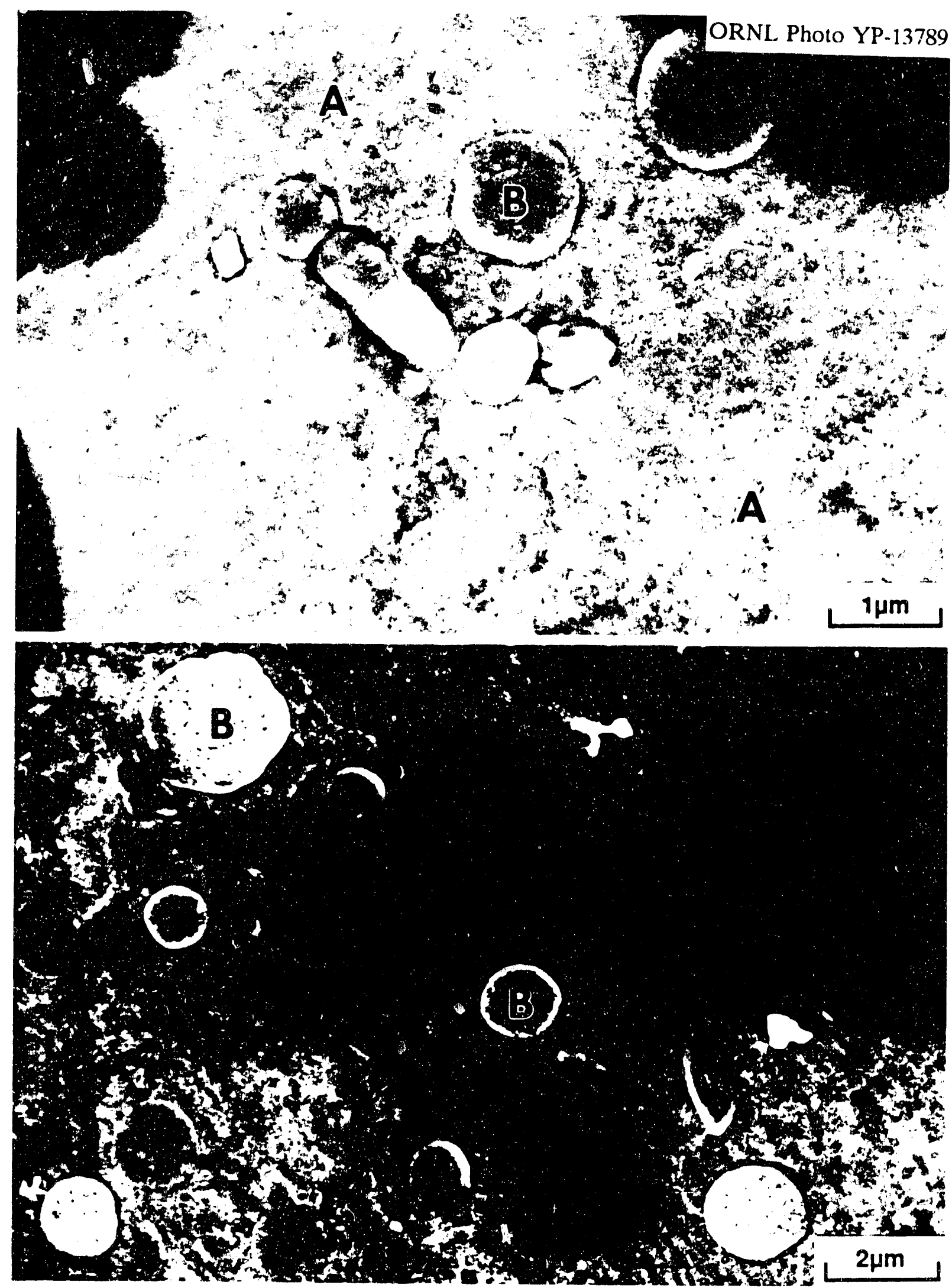

Fig. 8.10. Scanning electron micrographs of an oxidized pyrite specimen showing both continuous corrosion film (most of the surface such as around $(A)$ and discrete thicker corrosion pade (B). 


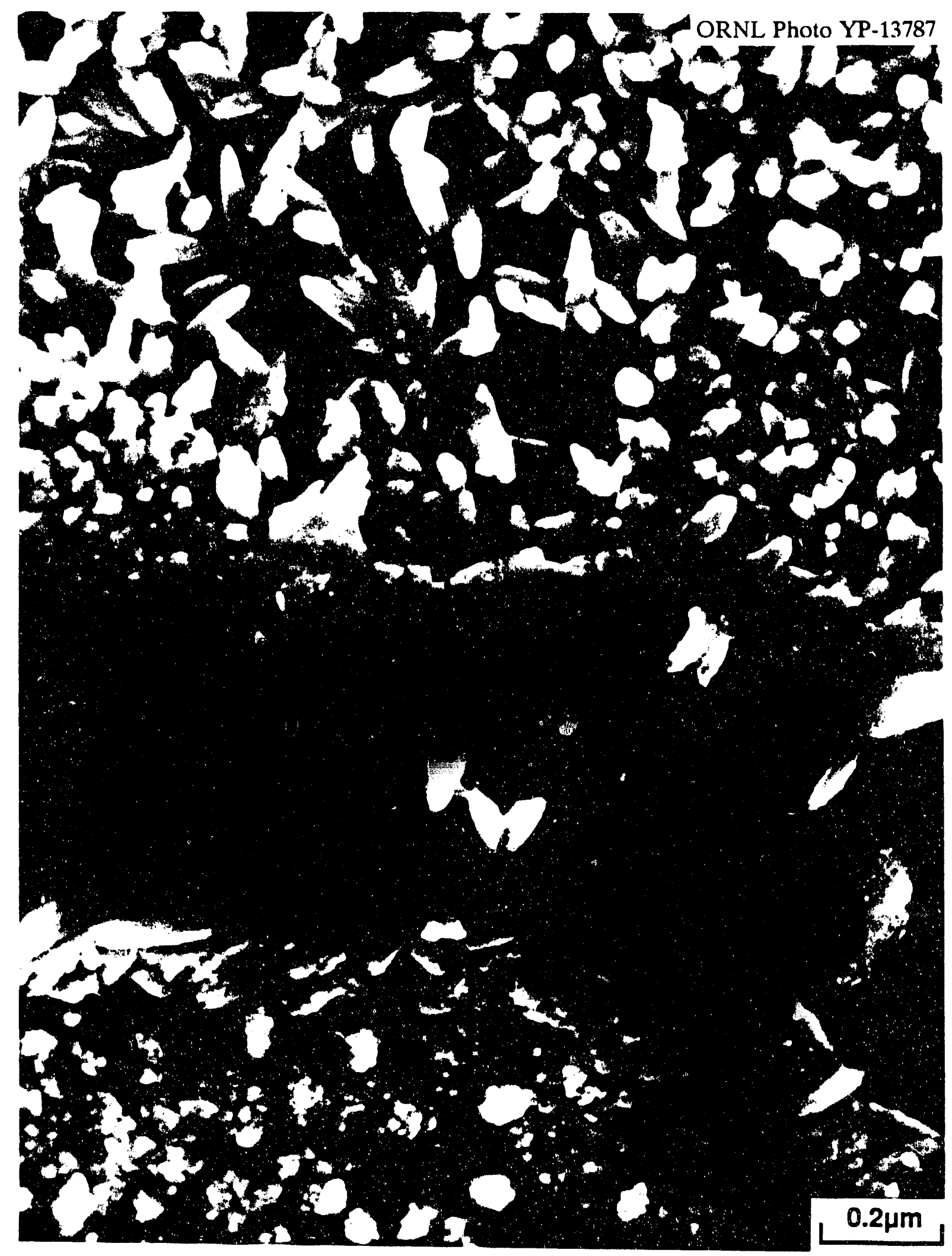

Fig. 8.11. High magnification scanning electron micrograph showing particles and crystallites that comprise the central portions of many of the corrosion pads. 
(see A, Fig. 8.12a and 8.12b). In regions where the pyrite was thicker (i.e. more material remained after ion-milling), the corrosion film covered both surfaces of the single crystal pyrite. However, the predominant features observed were the durk and light bands resulting from diffraction effects in the single crystal (see B, Figs. 8.12a and 8.12b). Utilizing electron diffraction, the continuous deposit was identified as containing goethite $[\mathrm{FeO}(\mathrm{OH})]$. Discrete reflections other than goethite and pyrite were not observed, but some amorphous material may have been present. Energy dispersive X-ray analysis (EDS) confirmed the presence of iron and oxygen; sulfur and carbon were also detected. The pads of corrosion were too thick to image clearly with TEM, however, electron diffraction of the pads revealed numerous rings whose d-spacings did not match to any single compound. In the pads, iron, sulfur, and oxygen were detected by EDS. Little or no carbon was present. Thus the pads are probably composed of several as yet unidentified iron, oxygen, and sulfur-containing compounds.

$\mathrm{X}$-ray diffraction of the surface of the larger specimen confirmed the presence of goethite as well as a single $\{200\}$ reflection from the single crystal pyrite. Additionally, X-ray diffraction of this specimen revealed the presence of pyrrhotite $\left(\mathrm{Fe}_{9} \mathrm{~S}_{10}\right)$. However, material containing this phase has not been located by TEM or electron diffraction. It is possible that either the pyrrhotite present in a few localized sites is unstable in the electron microscope environment (in the electron beam, for example), or is present only in thicker specimen regions where TEM techniques would not detect it.

\subsubsection{Second Pyrite Oxidation Experiment}

The goal of the second oxidation experiment was to produce specimens suitable for XPS. Only larger specimens were used and the experimental conditions and apparatus were the same with the exception that the exposure time was 48 hours rather than one week. The specimens lost some of their bright lustre during exposure. XPS analyses were performed on one of these specimens and on an unoxidized control. The unoxidized control (Fig. 8.13a) showed the presence of sulfur and iron as expected as well as oxygen and carbon. Adventitious oxygen and carbon are typically detected using XPS on specimens that have been exposed to ambient conditions due to the extremely shallow depth of analysis (typically less than $5 \mathrm{~nm}$ ) and the fact that oxygen and carbon-containing compounds rapidly contaminate most surfaces. After the oxidation experiment, oxygen had increased and sulfur was greatly decreased (Fig. 8.13b). These results fit well with the electron microscopy results of the first experiment. Traces of copper and tin were also found. The source of these elements is 


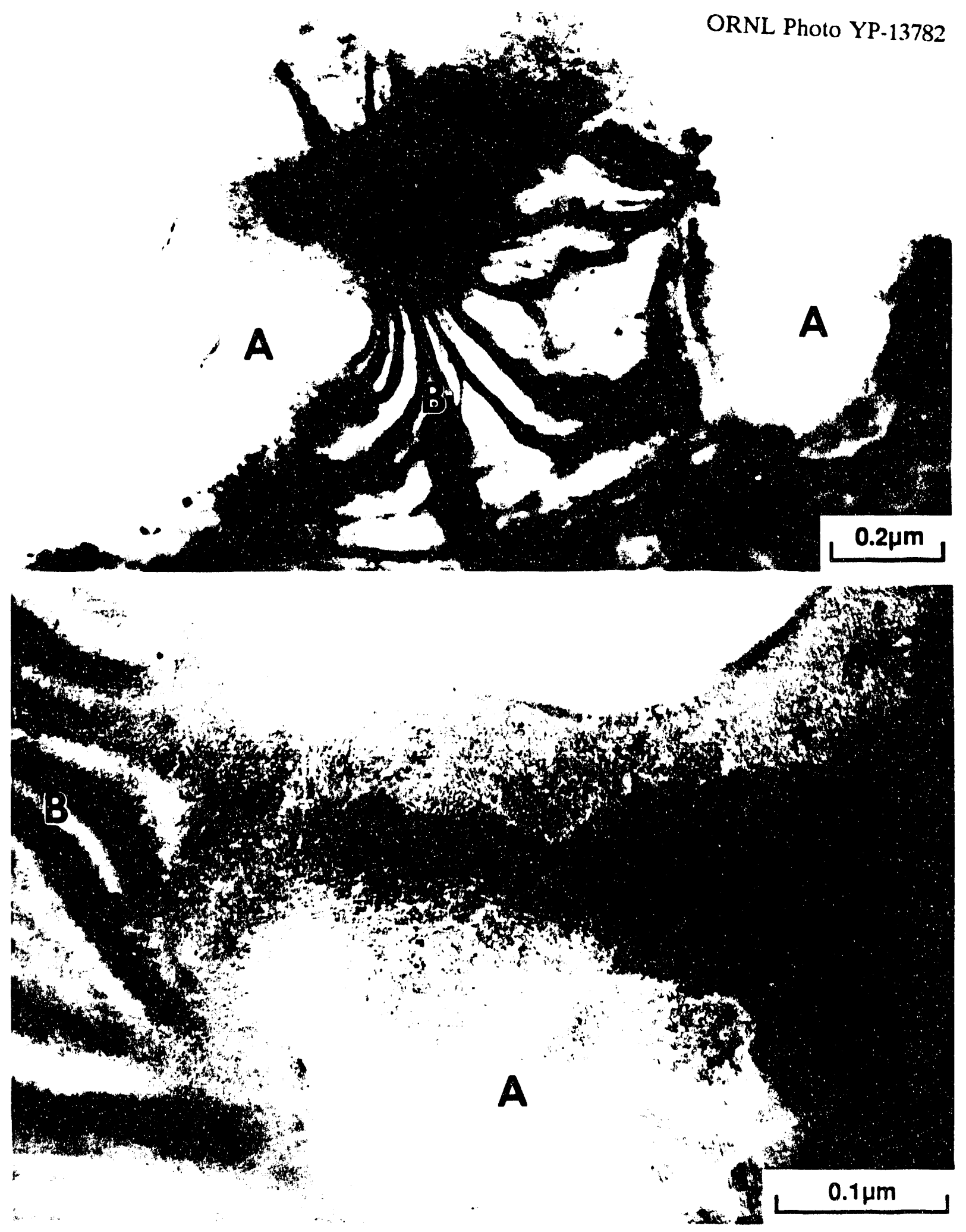

Fig. 8.12. Transmission elelctron micrographs showing regions where only corrosion material (primarily goethite) remain (A) and where corrosion material costs singlecrystalline pyrite (B). 
ORNL Photo YP-13790
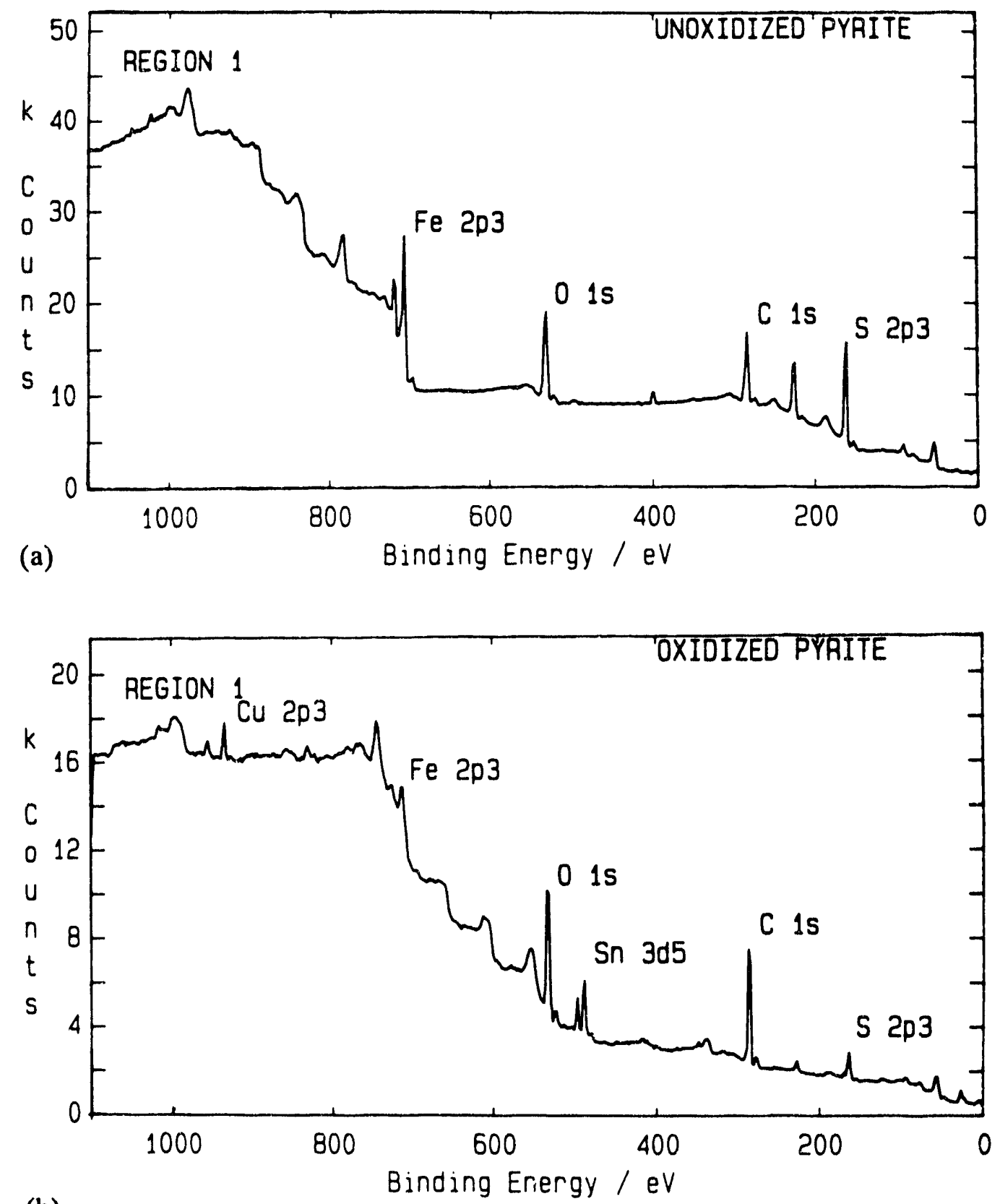

(b)

Fig. 8.13. XPS spectrum from the surface of (a) unoxidized pyrite control specimen, and (b) oxidized pyrite in a humid environment. Note the lower sulfur level compared to the (a). Also note the presence of copper and tin on the oxidized surface. 
unknown but could come from impurities within the pyrite that preferentially accumulated on the surface during oxidation.

\subsubsection{Conclusions and Recommendations for Future Research}

Observations of pyrite microcrystals comprising framboid structures in bulk coal specimens revealed the surprising result that a significant fraction of individual crystallites were in fact polycrystalline in nature. This phenomenon was also observed in bulk pyrite crystals which were sectioned to serve as substrates for controlled oxidation studies. Further studies to confirm these observations should be conducted. As yet we have no sound mechanism to explain the development of these crystal morphologies. The pyrite "crystals" in framboids were observed to have a uniform amorphous layer present, with an elemental composition suggesting an amorphous iron hydroxide. These observations led to studies of the oxidation of bulk single crystal pyrite surfaces.

The oxidation of large crystals of pyrite at high relative humidities results in a surface film of goethite that coats the pyrite. Goethite is a reasonable candidate for the material observed on the surfaces of the pyrite crystallites comprising the coal framboid structures. Pyrrohtite is also produced on large crystals and may be an intermediate compound in the oxidation process. Other compounds are produced, particularly in localized sites, that have not been identified. Sulfur is lost during the oxidation process presumably through the formation of one or more gas phases.

The results of the oxidation studies that have been performed as a part of this project suggest that further work could be quite rewarding in terms of understanding surface and interfacial phenomena of mineral impurities in coal. Oxidation under other experimental conditions (dry environments, for example) should provide insight into the range of environmental conditions that produces a surface coating of goethite on pyrite. More details of the sequence of chemical reactions that occur on the pyrite surface could be provided by the use of tools such as diffuse reflectance infrared spectroscopy, micro-Raman spectrometry, secondary ion mass spectrometry utilizing isotopic tracers, and high spatial resolution analytical electron microscopy using the ultra-fine beam of new high-brightness field emission gun TEM being installed in the High Temperature Materials Laboratory. Additionally, the exposure apparatus could be connected to mass spectrometric instrumentation to identify sulfur-containing gases released during oxidation. 


\subsubsection{References}

1. Pittsburgh No. 8 coal supplied by Praxis Engineering Company.

2. R. T. Greer, ACS Symposium Ser., No. 64, 1977, 3-15.

3. R. T. Greer, Energy Sources, 1978, 4(1), 23-59.

4. R. T. Greer, Scanning Electron Microscopy/1977, Vol. 1, 79-93. 


\section{INTERNAL DISTRIBUTION}
P. Angelini
A. Bleier
C. R. Boston
K. Breder
C. R. Brinkman
P. T. Carlson (2)
D. R. Childress
N. C. Cole
D. F. Craig
J. H. DeVan
W. Fulkerson
F. M. Haggag
L. L. Horton
C. R. Hubbard
R. R. Judkins (6)
J. R. Keiser
J. F. King
R. A. Lowden
R. C. Martin

C. G. McKamey

R. L. Miller

S. N. Nunn

A. E. Pasto

P. L. Rittenhouse

J. H. Schneibei

C. D. Scott

V. K. Sikka

G. M. Slaughter

D. P. Stinton

R. W. Swindeman

V. J. Tennery

J. R. Weir

Central Research Library (2)

Document Reference Section

Laboratory Records Department (2)

Laboratory Records, ORNL - RC

M\&C Records Office (2)

ORNL Patent Section

\section{EXTERNAL DISTRIBUTION}

M. Green

ABB LUMMUS CREST

1515 Broad St.

Bloomfield, NJ 07003

S. C. Weiner

AIR PRODUCTS AND CHEMICALS

7201 Hamilton Blvd., P.O. Box 538

Allentown, PA 18105

W. A. Ellingson

ARGONNE NATIONAL LABORATORY

9700 S. Cass Avenue

Argonne, IL 60565-4838

C. D. Livengood

ARGONNE NATTONAL LABORATORY

9700 S. Cass Avenue, Bldg. 362/2A

Argonne, IL 60439
D. K. Schmalzer

ARGONNE NATIONAL LABORATORY

9700 S. Cass Avenue

Argonne, IL 60439

J. H. Oxley

BATTELLE COLUMBUS LABORATORIES

505 King Avenue

Columbus, OH 43201

J. M. Chilton

BETHLEHEM STEEL CORPORATION

Homer Research Laboratories

Bethlehe «, PA 18016

G. Twizell

BRITISH GAS plc

Westfield Development Centre

Cardenden

Fife, Scotland KY5OHP 
Tom Butcher BROOKHAVEN NATTONAL LABORATORY Bldg. 475

Upton, NY 11973

G. Morales-Calvo

CIEMAT (Energetic, Environment and

Technological Research Center)

Programa Procesos Mineralurgicos

Avda, Complutense

22 Madrid 28040 Spain

E. Tilley-Hinkle

COAL AND SYNFUEIS TECHNOLOGY

1401 Wilson Blvd., Suite 900

Arlington, VA 22209

R. A. Wolfe

COAL TECHNOLOGY CORP.

103 Thomas Rd.

Bristol, VA 24201

R. E. Wright

COAL TECHNOLOGY CORP.

103 Thomas Rd.

Bristol, VA 24201

F. P. Burke

CONSOLIDATION COAL CO.

R\&D Department

4000 Brownsville Road

Library, PA 15129

D. G. Nichols

CONSOLIDATION COAL $C O$.

R\&D Department

4000 Brownsville Road

Library, PA 15129

J. $\mathrm{K}$ Weddell

DUPONT FIBERS

Experimental Station, E302

Wilmington, DE 19880-0302

C. A. Lundgren

DUPONT FIBERS

Experimental Station, E302

Wilmington, DE 19880-0302
W. D. Hewett

DUPONT FIBERS

Pencader Plant, CMC

P.O. Box 6100

Newark, DC 19714

S. B. Alpert

EIECTRIC POWER RESEARCH INSTITUTE

P.O. Box 10412

3412 Hillview Avenue

Palo Alto, CA 94303

D. M. Golden

ELECTRIC POWER RESEARCH INSTITUTE

P.O. Box 10412

3412 Hillview Avenue

Palo Alto, CA 94303

J. Stringer

ELECTRIC POWER RESEARCH INSTTTUTE

P.O. Box 10412

3412 Hillview Avenue

Palo Alto, CA 94303

H. Weisenfeld

ENERGETICS, INC.

7164 Gateway Dr.

Columbia, MD 21046

K. T. Janes

ENVIRONMENTAL PROTECTION AGENCY

Global Warming Control Div. (MD-63)

Research Triangle Park, NC 27711

Y.C.L Susan Wu

ERC, INCORPORATED

P. O. Box 417

Tullahoma, TN 37388

M. L. Gorbaty

EXXON RESEARCH \& ENGINEERING CO.

Route 22 East, Clinton TWP

Annadale, NJ 08801

Heidrun Barnert-Wiemer FORSCHUNGS ZENTRUM JULICH GmbH Institute for Chemical Technology

Postfach 1913

D-5170 Jalich, Germany 
Martin Novack

GENERAL APPLIED SCIENCE LABS

77 Raynor Ave.

Ronkonkoma, NY 11779

J. A Todd

ILINOIS NNSTITUTE OF TECHNOLOGY

Dept. Metallurgical \& Materials Engr.

Chicago, IL 60616

P. A. Lowe

INTECH, INC.

11316 Roven Drive

Potomac, MD 20854-3126

Maury Saddy

INTER-UHDE ENGENHARIA OWIMICA

LTD

Rua Pedro Americo 32-25 ${ }^{\circ}$ Andar

Sao Paulo, SP 01045

R. L. Phen

JET PROPULSION LABORATORY

4800 Oak Grove Drive - MS 79-21

Pasadena, CA 91020

M. H. Van de Voorde

JOINT RESEARCH CENTRE OF THE

EUROPEAN COMMUNTTIES

Westerduinweg 3, P.O. Box 2

1755 ZG Petten, The Netherlands

S. T. Viscontini

MOBIL RESEARCH \& DEVELOPMENT CORPORATION

Engineering Department

P. O. Box 1026

Princeton, NJ 08540

J. P. Gyekenyesi

NASA LEWIS RESEARCH CENTER

21000 Brookpark Road (MS 6-1)

Cleveland, $\mathrm{OH} 44135$

S. R. Levine

NASA LEWIS RESEARCH CENTER

21000 Bronkpark Road

Cleveland, $\mathrm{OH} 44135$
S. J. Dapkunas

NATIONAL INSTITUTE OF STANDARDS AND TECHNOLOGY

Materials Building, A259

Gaithersburg, MD 20899

S. Hirano

NEW ENERGY AND INDUSTRIAL TECHNOLOGY DEVELOPMENT ORGANIZATION

Sunshine 60 Bldg., P.O. Box 1151

Higashi-Ikebukuro, Toshima-Ku

Tokyo, 170 Japan

T. Fukumizu

NEW ENERGY AND INDUSTRIAL TECHNOLOGY DEVELOPMENT ORGANIZATION

1800 K Street, NW, Suite 924

Washington, DC 20006

H. T. Burn

OAK RIDGE INSTITUTE FOR SCIENCE AND EDUCATION

P. O. Box 117

Oak Ridge, TN 37831-0117

J. B. O'Hara

RALPH M. PARSONS COMPANY

100 W. Walnut St.

Pasadena, CA 91124

Aksel Olsen

RISOE NATIONAL LABORATORY

P.O. Box 49

Roskilde 4000, Denmark

S. McNulty

SHELLADIA, INC.

Suite 100, 15825 Shady Grove Rd.

Rockville, MD 20850

G. Sorell

G. SORELL CONSULTING SERVICES

49 Brookside Terrace

North Caldwell, NJ 07006

J. H. Laue

SRS TECHNOLOGIES

990 Explorer Blvd., NW

Huntsville, AL 35806 
Herman Research Laboratory Library

STATE EIECTRICITY COMMISSION OF VICTORIA

Howard Street

Richmond, Victoria, 3121, Australia

C. M. Huatig

TENNESSEE VALLEY AUTHORTTY

Research \& Development

MR 3A

Chattanooga, TN 37402-2801

Harry Cheung

UNION CARBIDE INDUSTRIAL GASES, INC.

Linde Division

P.O. Box 44, 175 East Park Drive

Tonawanda, NY 14151

Gilbert Kirsch

UNIVERSITE DE METZ

Laboratoire de Chimie Organique

Faculty des Sciences

Ile du Saulcy 57

Metz, France

O. J. Hahn

UNIVERSITY OF KENTUCKY

Mechanical Engineering Department

Lexington, KY 40506-0046

I. Wender

UNIVERSITY OF PITTSBURGH

1249 Benedum Hall

Pittsburgh, PA 15261

K. N. Strafford

UNIVERSITY OF SOUTH AUSTRALIA

Department of Metallurgy

The Levels SA 5095, Australia

K. Fuhrmann

VEBA OEL

P. O. Box 45

4650 Gelsenkirchen-Buer

W. Germany

D. H. Archer

WESTINGHOUSE ELECTRIC CORP.

114 Kentzel Road

Pittsburgh, PA 15237-2816
D. L Keairns

WESTINGHOUSE SCIENCE AND TECHNOLOGY CENTER

1310 Beulah Road

Pittsburgh, PA 15235

N. Swift

DEPARTMENT OF ENERGY

Chicago Operations Office

9800 S. Cass Ave.

Argonne, Il 60439

D. C. Cicero

DEPARTMENT OF ENERGY

Morgantown Energy Technology Center

P.O. Box 880

Morgantown, WV 26505

M. R. Ghate

DEPARTMENT OF ENERGY

Morgantown Energy Technology Center

P.O. Box 880

Morgantown, WV 26505

J. S. Halow

DEPARTMENT OF ENERGY

Morgantown Energy Technology Center

P.O. Box 880

Morgantown, WV 26505

N. T. Holcombe

DEPARTMENT OF ENERGY

Morgantown Energy Technology Center P.O. Box 880

Morgantown, WV 26505

W. R. Miller

DEPARTMENT OF ENERGY

Morgantown Energy Technology Center

P.O. Box 880

Morgantown, WV 26505

J. E. Notestein

DEPARTMENT OF ENERGY

Morgantown Energy Technology Center

P.O. Box 880

Morgantown, WV 26505 
J. S. Wilson

DEPARTMENT OF ENERGY

Morgantown Energy Technology Center

P.O. Box 880

Morgantown, WV 26505

J. Mosquera

DEPARTMENT OF ENERGY

Naval Reactors, NE-60

Crystal City, Bldg. N.C.-2

Washington, DC 20585

Deputy Assistant Manager for Energy

Research and Development

DEPARTMENT OF ENERGY

Oak Ridge Operations Office

P.O. Box 2008

Oak Ridge, TN 37831-6269

E. E. Hoffman

DEPARTMENT OF ENERGY

Oak Ridge Operations Office

P.O. Box 2008

Oak Ridge, TN 37831-6269

D. J. Beecy

DEPARTMENT OF ENERGY

Office of Fossil Energy, FE-13

1000 Independence Avenue

Washington, DC 20545

R. J. Braitsch

DEPARTMENT OF ENERGY

Office of Fossil Energy, FE-13

1000 Independence Avenue

Washington, DC 20545

J. P. Carr

DEPARTMENT OF ENERGY

Office of Fossil Energy, FE-14

1000 Independence Avenue

Washington, DC 20545

W. Fedarko

DEPARTMENT OF ENERGY

Office of Fossil Energy, FE-232

1000 Independence Avenue

Washington, DC 20545
H. N. Giles

DEPARTMENT OF ENERGY

Office of Fossil Energy, FE-442

1000 Independence Avenue

Washington, DC 20545

F. M. Glaser

DEPARTMENT OF ENERGY

Office of Fossil Energy, FE-14

1000 Independence Avenue

Washington, DC 20545

D. Gray

DEPARTMENT OF ENERGY

Office of Fossil Energy, FE-431

1000 Independence Avenue

Washingten, DC 20545

A. W. Hemenway DEPARTMENT OF ENERGY Office of Fossil Energy, FE-24

1000 Independence Avenue

Washington, DC 20545

R. L. Kane

DEPARTMENT OF ENERGY

Office of Fossil Energy, FE-13

1000 Independence Avenue

Washington, DC 20545

F. A. Leone

DEPARTMENT OF ENERGY

Office of Fossil Energy, FE-35

1000 Independence Avenue

Washington, DC 20545

J. J. Pyrdol

DEPARTMENT OF ENERGY

Office of Fossil Energy, FE-13

1000 Independence Avenue

Washington, DC 20545

P. C. Scott

DEPARTMENT OF ENERGY

Office of Fossil Energy, FE-14

1000 Independence Avenue

Washington, DC 20545 
T. B. Simpson

DEPARTMENT OF ENERGY

Office of Fossil Energy, FE-231

1000 Independence Avenue

Washington, DC 20545

\section{I. Singer}

DEPARTMENT OF ENERGY

Office of Fossil Energy, FE-30

1000 Independence Avenue

Washington, DC 20545

H. E. Thomas

DEPARTMENT OF ENERGY

Office of Fossil Energy, FE-33

1000 Independence Avenue

Washington, DC 20545

G. E. Voelker

DEPARTMENT OF ENERGY

Office of Fossil Energy, FE-23

1000 Independence Avenue

Washington, DC 20545

G. F. Wheeler

DEPARTMENT OF ENERGY

Office of Fossil Energy, FE-231

1000 Independence Avenue

Washington, DC 20545

N. F. Barr

DEPARTMENT OF ENERGY

Office of Health and Environmental Research, ER-72

Washington, DC 20585

F. J. Wobber

DEPARTMENT OF ENERGY

Office of Health and Environmental Research, ER-75

14 Goshen $\mathrm{Ct}$.

Gaithersburg, MD 20882-1016

A. L. Baldwin

DEPARTMENT OF ENERGY

Pittsburgh Energy Technology Center

P.O. Box 10940

Pittsburgh, PA 15236
S. W. Chun

DEPARTMENT OF ENERGY

Pittsburgh Energy Technology Center

P.O. Box 10940

Pittsburgh, PA 15236

R. C. Dolence

DEPARTMENT OF ENERGY

Pittsburgh Energy Technology Center

P.O. Box 10940

Pittsburgh, PA 15236

J. L. Hebb

DEPARTMENT OF ENERGY

Pittsburgh Energy Technology Center

P.O. Box 10940

Pittsburgh, PA 15236

J. D. Hickerson

DEPARTMENT OF ENERGY

Pittsburgh Energy Technology Center

P.O. Box 10940

Pittsburgh, PA 15236

\section{J. J. Lacey}

DEPARTMENT OF ENERGY

Pittsburgh Energy Technology Center

P.O. Box 10940

Pittsburgh, PA 15236

S. R. Lee

DEPARTMENT OF ENERGY

Pittsburgh Energy Technology Center P.O. Box 10940

Pittsburgh, PA 15236

M. E. Maher

DEPARTMENT OF ENERGY

Pittsburgh Energy Technology Center

P.O. Box 10940

Pittsburgh, PA 15236

\section{S. Rogers}

DEPARTMENT OF ENERGY

Pittsburgh Energy Technology Center

P.O. Box 10940

Pittsburgh, PA 15236 
J. A. Ruether

DEPARTMENT OF ENERGY

Pittsburgh Energy Technology Center

P.O. Box 10940

Pittsburgh, PA 15236

R. Santore

DEPARTMENT OF ENERGY

Pittsburgh Energy Technology Center

P.O. Box 10940

Pittsburgh, PA 15236

T. M. Torkos

DEPARTMENT OF ENERGY

Pittsburgh Energy Technology Center

P.O. Box 10940

Pittsburgh, PA 15236

DEPARTMENT OF ENERGY

Office of Scientific and Technical Information

P. O. Box 62

Oak Ridge, TN 37831

For distribution by microfiche as shown in DOE/OSTI-4500, Distribution Categories UC122 [Enhanced Oil Recovery (Heavy, Light)], UC-123 (Oil Shale and Tar Sands), UC-125 (Liquid Fuels Research), UC-126 (Petroleum Reserves), and UC-132 (Unconventional Gas Recovery). (10 copies) 

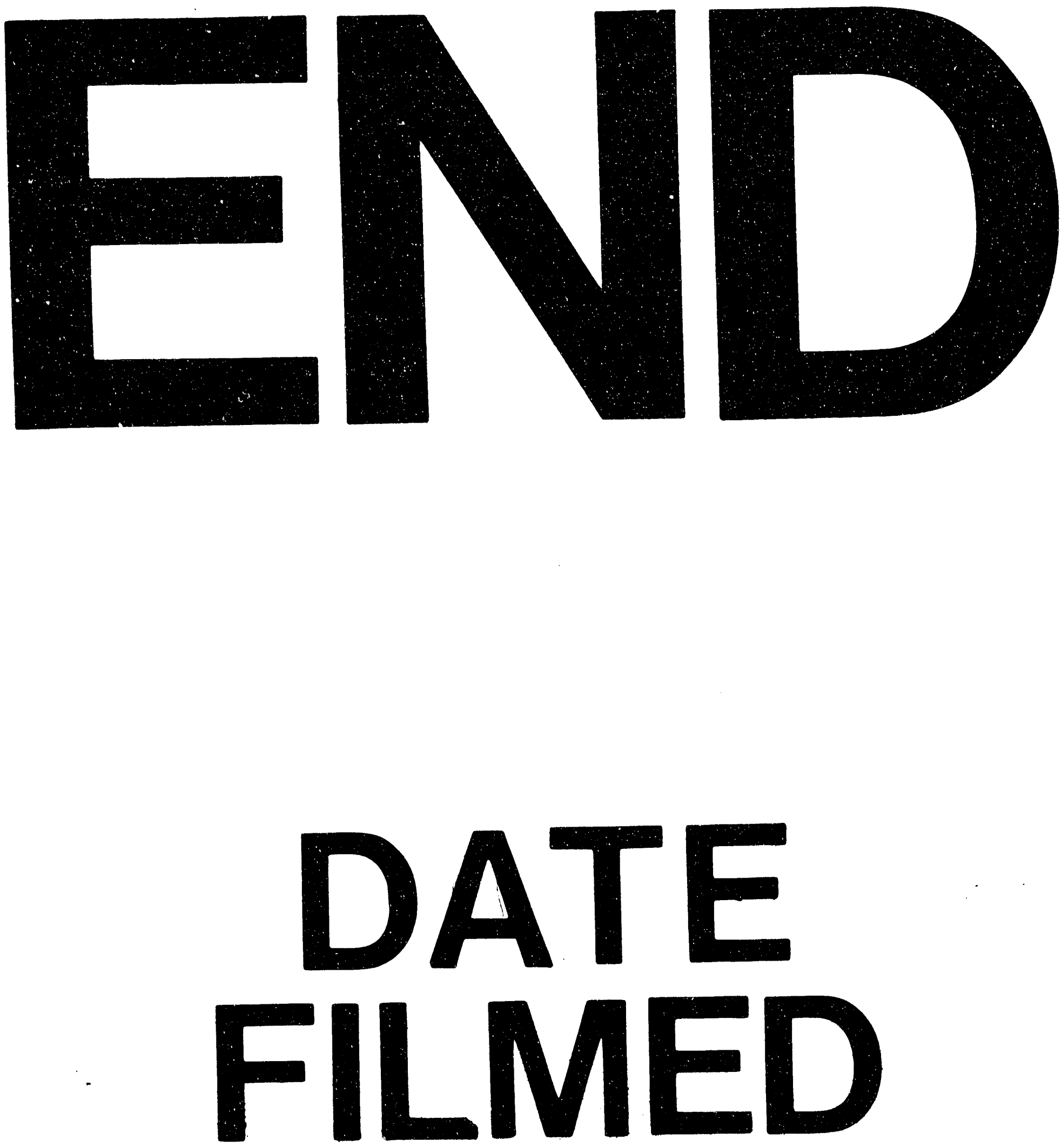

I

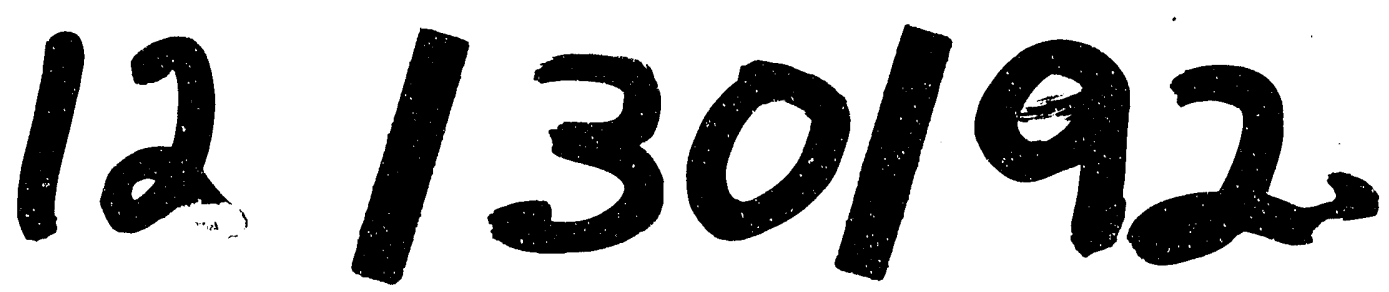


